\title{
SYSTEM FINANSOWY W MULTIPERSPEKTYWIE
}

\author{
KsIĘGA JUBILEUSZOWA \\ Z OKAZJI SIEDEMDZIESIĄTYCH URODZIN \\ PROFESORA MARIANA GÓRSKIEGO
}





\title{
SYSTEM FINANSOWY
}

\section{W MULTIPERSPEKTYWIE}

\author{
KSIĘGA JUBILEUSZOWA \\ Z OKAZJI SIEDEMDZIESIĄTYCH URODZIN \\ PROFESORA MARIANA GÓRSKIEGO
}

REDAKCJA NAUKOWA

JAKUB GÓRKA

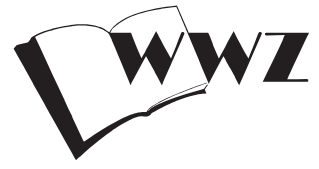

Wydawnictwo Naukowe

Wydziału Zarzadzania

Uniwersytetu Warszawskiego

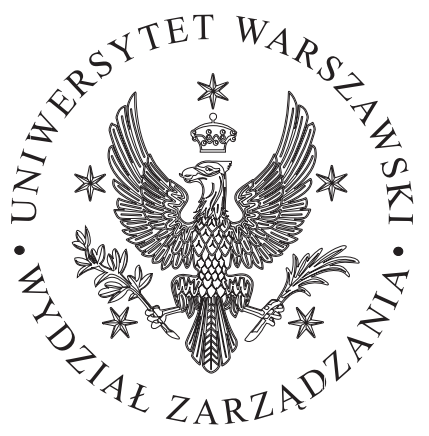


Recenzenci: prof. zw. dr hab. Jan K. Solarz (Społeczna Akademia Nauk) dr hab. Marek Monkiewicz (Wydział Zarządzania, Uniwersytet Warszawski)

Redakcja: Anita Sosnowska

Projekt okładki: Agnieszka Miłaszewicz

(C) Copyright by Wydawnictwo Naukowe Wydziału Zarządzania Uniwersytetu Warszawskiego, Warszawa 2018

Publikacja dofinansowana $\mathrm{z}$ dotacji na utrzymanie potencjału badawczego na Wydziale Zarządzania Uniwersytetu Warszawskiego.

Wszelkie prawa zastrzeżone. Kopiowanie, przedrukowywanie i rozpowszechnianie całości lub fragmentów bez uzyskania pozwolenia zabronione.

ISBN 978-83-65402-85-1

e-ISBN 978-83-65402-86-8

https://doi.org/10.7172/978-83-65402-86-8.2018.wwz.8

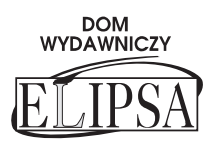

Opracowanie komputerowe, druk i oprawa:

Dom Wydawniczy ELIPSA

ul. Inflancka 15/198, 00-189 Warszawa

tel. 226350301

e-mail: elipsa@elipsa.pl,www.elipsa.pl 


\section{Spis treści}

Alojzy Z. Nowak

Stowo wstępne................................... 9

Waldemar Frąckowiak

Profesor Marian Górski uczony - nauczyciel - dziatacz gospodarczy....... 11

Listy gratulacyjne ................................. 19

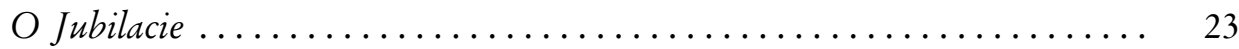

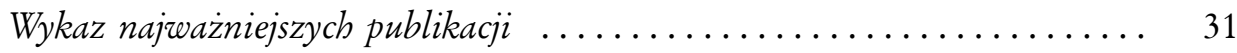

Wykaz wypromowanych doktoratów ...................... 37

\section{System finansowy - analizy i rozważania}

Krzysztof Jajuga

Financial Investments - Systematization .................... 41

Leszek Pawłowicz

„Moral hazard" w pośrednictwie finansowym .................. 55

Krzysztof Kalicki

Wptyw regulacji $i$ obciażen finansowych na sektor bankowy w UE $i$ w Polsce ........................................ 71

Jerzy Żyżyński

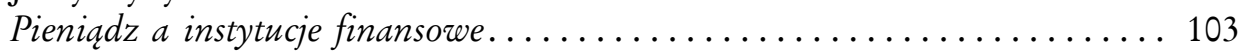

Grzegorz Jędrzejczak

Upadek gospodarki PRL trzydzieści lat później. O wyobraźni ekonomistów

Ewa Krakowińska

Źródta finansowania podmiotów ekonomii spotecznej w Polsce

Renata Karkowska, Andrzej Sopoćko

Zjawisko zmienności i wospótzależności indeksów na rynku kapitatowym. . . 149 
Małgorzata Olszak

Rezerwy na ryzyko kredytowe w standardach adekwatności kapitatowej. . . 165

Patrycja Chodnicka-Jaworska, Piotr Jaworski, Katarzyna Niewińska

Wplyw credit ratingów krajów na zmienność kursów akcji banków europejskich ...................................... 181

Jakub Górka

Architektura i pryncypia systemu finansowego. Rozważania w perspektywie szkoty finansowej Profesora Mariana Górskiego

\section{„Profesor Marian Górski w moich oczach”. Notki i wspomnienia}

Anna Bielecka - Profesor Marian Górski w moich oczach ............ 221

Beata Glinka - Pocbwata racjonalności ................... 223

Roman Głowacki - Profesor Marian Górski w kontekście kilku epizodów . . . 225

Jakub Górka - Profesor Marian Górski w moich oczach - profesor, preceptor,

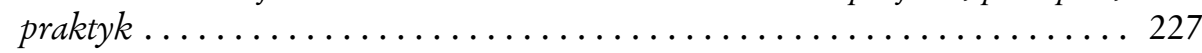

Grzegorz Jędrzejczak - Profesor Marian Górski w moich oczach ........ 230

Krzysztof Kalicki - Profesor Marian Górski w moich oczach ........... 232

Renata Karkowska - Renata dla Profesora Mariana Górskiego .......... 234

Marcin Kobus - Profesor Marian Górski w moich oczach ............ 237

Monika Kostera - O zarzadzaniu i kontekście - $i$ dlaczego to jest ważne. . . . . 239

Ewa Krakowińska - Kilka zdań od bytej studentki .............. 243

Adam Parfiniewicz - Z okazji 70. urodzin Profesora Mariana Górskiego . 246

Leszek Pawłowicz - Profesor Marian Górski w moich oczach .......... 249

Stanisław Piątek - Kilka wwag na siedemdziesięciolecie .............. 251

Ewa Pietrusińska, Robert Pietrusiński - Profesor Marian Górski....... 253

Ryszard Rapacki - Tekst „wspomnieniowy” do ksiązki jubileuszowej

Profesora Mariana Górskiego.......................... 255

Kazimierz Ryć - Profesor Marian Górski..................... 257

Piotr Sokół i Jacek Kiryło - O Profesorze Marianie Górskim.......... 260

Mariusz Trojanowski - Profesor Marian Górski w moich oczach ........ 263

Radosław Winiarski - Profesor Marian Górski w moich oczach.......... 265

Eleonora Zielińska - Profesor Marian Górski w moich oczach .......... 268 


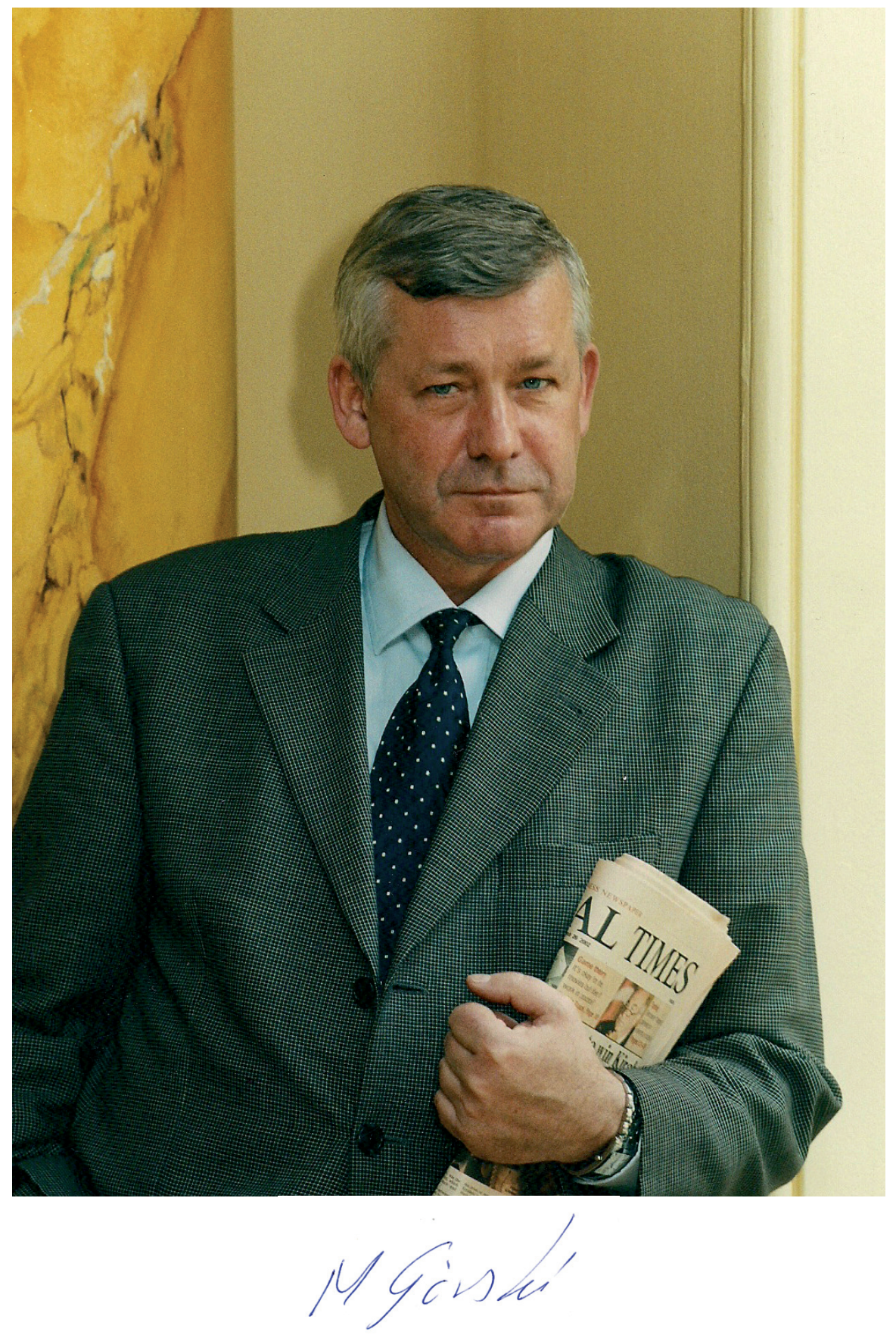





\section{ALOJZY Z. NOWAK}

\section{Stowo wstepne}

Profesor Marian Górski w tym roku obchodzi swój Jubileusz. Jego bliscy Współpracownicy i Przyjaciele przygotowali z tej okazji publikację będąca wyrazem szacunku i uznania dla Profesora. Dobór Autorów oraz tematyka zawartych w monografii opracowań świadczą o szerokich zainteresowaniach Jubilata. Jego zainteresowania badawcze, szczególnie w zakresie makroekonomii, polityki gospodarczej, równowagi gospodarczej, pieniądza i polityki pieniężnej oraz bankowości i systemów finansowych są w dużej mierze odzwierciedlone w Księdze Jubileuszowej w artykułach wybitnych naukowców.

Prace naukowe Profesora Górskiego i publikowane wyniki badań zawsze wywierały znaczny wpływ na środowisko naukowe i gospodarcze. Tak było, kiedy pracował równolegle na Wydziale Zarządzania UW i w Instytucie Finansów, a także wtedy, kiedy zasiadał w licznych radach nadzorczych polskich i zagranicznych instytucji finansowych.

Marian Górski jest jednym z filarów Wydziału Zarządzania Uniwersytetu Warszawskiego. To jeden z pierwszych zatrudnionych pracowników naukowych na Wydziale. Prowadzone przez niego wykłady czy to z matematyki, czy z ekonomii, czy z finansów zawsze cieszyły się dużym uznaniem słuchaczy, ze względu na zawartość merytoryczną, spójność logiczną i poprawność metodologiczna. $\mathrm{Na}$ swoich seminariach wykształcił On rzeszę znakomitych tak magistrów, jak i doktorów, spośród których wielu jest profesorami i doktorami habilitowanymi.

Profesor Marian Górski odegrał znaczącą rolę w tworzeniu rynku finansowego $\mathrm{w}$ Polsce, poprzez zarówno liczne i znaczące publikacje $\mathrm{w}$ tym zakresie, jak i aktywne uczestnictwo w strukturach rynku finansowego. Marian Górski był Dziekanem Wydziału Zarządzania, za czasów którego dokonano pierwszej głębokiej zmiany i restrukturyzacji programów nauczania na Wydziale Zarządzania. To wtedy właśnie utworzono Dyplomowe Studia 
Magisterskie (DSM), które na wiele lat stały się filarem edukacji menedżerskiej nie tylko na Wydziale Zarządzania UW, lecz także w całej Polsce.

Seminaria i wykłady prowadzone przez Profesora Mariana Górskiego stały i stoją zawsze na bardzo wysokim poziomie merytorycznym. Osąd Profesora, jego mądrość w formułowaniu poglądów i opinii wywarły i wywierają istotny wpływ na kształtowanie się tożsamości naukowej, dydaktycznej i organizacyjnej Wydziału.

Szanowny Jubilat, jako znakomity finansista, od kilku lat przewodzi także Komisji Senackiej ds. Budżetu i Finansów na Uniwersytecie Warszawskim. $Z$ jego zdaniem liczą się władze zarówno Uniwersytetu, jak i Senatu Uniwersytetu Warszawskiego.

Drogi Marianie, z okazji Twojego Jubileuszu życzę Ci wszystkiego co najpiękniejsze; zdrowia, szczęścia i wszelkiej pomyślności. Jednocześnie w imieniu własnym i całej społeczności akademickiej Wydziału Zarządzania UW dziękuję Ci za lata pracy, mądrą politykę prowadzoną na Wydziale oraz zawsze merytoryczne podejście w rozwiązywaniu problemów. Twój wpływ na rozwój Wydziału nie może być przeceniony.

Alojzy Z. Nowak Dziekan 


\section{WALDEMAR FRĄCKOWIAK*}

\section{Profesor Marian Górski \\ uczony - nauczyciel - dziatacz gospodarczy}

Tworzenie rzeczy ważnych, o szerokim wpływie na rozwój spraw ważkich społecznie jest przywilejem niewielu. Tych - którzy obdarowani rzadkimi talentami używają ich do lepszego zrozumienia otaczającego świata, a zarazem mają wolę dzielenia się nimi z ogółem. Tych - którzy oferują rzeczy aktualne, wszak zbudowane na racjonalistycznej koncepcji rozumu. Tych - którzy mają szczególną zdolność do podważania utartych schematów i wykraczania poza uznane granice metodologiczne i, co więcej, do zachowania suwerenności intelektualnej i odwagi głoszenia nowych myśli. Tych - dla których początkiem naukowego poznania jest zdziwienie, a jego owoc wiedza, czyli zrozumieniem przyczyn, a więc wiedzą prawdziwą wiedzą przyczynową. Tych - którzy mają odwagę być mądrym i podążać w nieznanych kierunkach w poszukiwaniu prawdy, bo podzielają pogląd Arystotelesa, że choć korzenie nauki są gorzkie i wymagają wielorakich wyrzeczeń i poświęcenia, to jej owoce mogą być słodkie.

Doświadczenie ludzkie potwierdza, że skupienie tych przymiotów w jednej osobie jest darem przynależnym tylko wybrańcom. Do tych niewątpliwie należy Profesor Marian Górski, którego całokształt dorobku zawodowego, składający się z obfitej pracy uczonego, nauczyciela i działacza społecznogospodarczego, oraz Jego znaczenie dla współczesności doprawdy trudno przecenić.

* Waldemar Frąckowiak, prof. dr hab. w zakresie nauk ekonomicznych i finansów, prof. zw. Uniwersytetu Ekonomicznego w Poznaniu, Katedra Inwestycji i Rynków Kapitałowych. 
Kim jest Profesor Marian Górski? Co składa się na Jego osobowość twórczą? Co sprawia, że do swego 70-lecia urodzin dokonał tak wiele doniosłych rzeczy na licznych polach działalności? Co powoduje, że owoce Jego pracy są słodkie, ale też społecznie pożyteczne?

\section{II}

Kariera zawodowa Profesora Mariana Górskiego odznacza się niezwykłą dynamiką rozwojową. Oto śledząc stale pomnażany dorobek Profesora, łatwo potwierdzić starą maksymę, iż myśli późniejsze są lepsze od poprzednich. Manifestuje się to w systematycznym wzbogacaniu tego dorobku w wymiarze ilościowym, ale też osiąganiu nowych pułapów jakościowych. U podstaw tego procesu tkwi rzadko spotykany talent i ogromna pracowitość, twórczo wykorzystane na gruncie znakomitego wykształcenia i wielostronnego doświadczenia. W efekcie pozwala $\mathrm{Mu}$ to rozwijać swą misję zawodową z perspektywy głębokiej i wszechstronnej wiedzy, a także spoglądać na dotąd słabo rozpoznane obszary oraz na to, co widzieli już inni i dojrzeć to, czego inni nie dostrzegli.

\section{III}

Profesor M. Górski związany jest z twórczością naukową i działalnością dydaktyczną od 47 lat. Wykształcenie wyższe odebrał na Uniwersytecie Warszawskim, na Wydziale Nauk Ekonomicznych, na kierunku ekonometria (1971 r.). Zaraz potem podjął staż asystencki, tam się doktoryzował (1978 r.) na podstawie rozprawy pt. Konsumpcja w planistycznych modelach wzrostu gospodarki socjalistycznej, wydanej przez PWN w 1982 r. i wyróżnionej Nagrodą Ministra Nauki i Szkolnictwa Wyższego. Stopień doktora habilitowanego uzyskał w 1987 r. na podstawie współautorskiej (G. Jędrzejczak) książki, wydanej w tymże roku przez PWN, pt. Równowaga i stabilność w gospodarce socjalistycznej. Ponadto uzupełniał i pogłębiał wiedzę oraz prowadził badania naukowe $\mathrm{w}$ prestiżowych ośrodkach zagranicznych (Uniwersytet Carleton, Kanada; Uniwersytet w Hamburgu, Niemcy; Kellog's School of Northwestern University, USA; Wharton School of Pennsylvania University, USA). Łącznie na studiach zagranicznych spędził ponad 2,5 roku, czego rezultatem były liczne publikacje w kraju i za granicą. Od 1989 r. poza kontynuacją pracy na Wydziale Zarządzania UW objął stanowisko profe- 
sora nadzwyczajnego w Instytucie Finansów (1989-1995), gdzie prowadził główne badania naukowe. Tytuł profesora nauk ekonomicznych uzyskał w 2007 roku, a stanowisko profesora zwyczajnego w Zakładzie Bankowości i Rynków Finansowych Uniwersytetu Warszawskiego objął w 2010 r. Obecnie jest kierownikiem Katedry Systemów Finansowych Gospodarki i Zakładu Bankowości i Rynków Pieniężnych.

\section{IV}

Jak następny dzién jest uczniem poprzedniego, tak późniejszy dorobek Profesora jest owocem wcześniejszego. Rzuca się w oczy konsekwentna linia badawcza, kontynuacja, ale zarazem ciągłe pogłębianie i poszerzanie badanych fragmentów rzeczywistości społeczno-gospodarczej. W dorobku tym przebija się zasada, że choć myśl naukowa może rozwijać się wieloma torami, to prawda jest jedna, najczęściej wszak złożona i wielowymiarowa. Dążenie do niej poprzez intelektualne zmagania z coraz bardziej skomplikowaną materią to imperatyw metodologiczny, jaki przewodzi poczynaniom badawczym Profesora.

W procesie badań naukowych, a w ślad za tym w bogatym dorobku naukowym Profesora dają się wyraźnie wyodrębnić trzy postępujące po sobie, ale ściśle zazębiające się nurty badawcze:

- problemy równowagi i stabilności makroekonomicznej gospodarki (do pierwszej połowy lat $90 . \mathrm{XX}$ wieku);

- funkcjonowanie rynków finansowych i bankowości (druga połowa lat 90. XX wieku i początek XXI wieku);

- polityka makroekonomiczna, a zwłaszcza monetarna, fiskalna i strukturalna (od końca pierwszej dekady XXI wieku do czasów obecnych).

Już w najwcześniejszych pracach naukowych Profesora zaznacza się modelowe postrzeganie, opis i analiza zjawisk gospodarczych. Wykorzystywane, uzupełniane, a także budowane przez Niego modele wybranych fragmentów gospodarki są nie tylko wyrazem syntetycznego podejścia pozwalającego lepiej zrozumieć i usystematyzować opisywane zjawiska i związki między nimi, lecz także często są empirycznie weryfikowane i służą celom praktycznym, zwłaszcza prognozowaniu.

W opublikowanych $\mathrm{w}$ PWN pracy magisterskiej (1976 r.), a później doktorskiej, Profesor opisał gospodarkę narodową w modelu przepływów międzygałęziowych i w optymalizujących modelach wzrostu. Kardynalne 
znaczenie dla pierwszego nurtu badán Profesora miała Jego współautorska rozprawa habilitacyjna. Praca ta przeciwstawia się powszechnemu w tym okresie paradygmatowi Antyequilibrium, wylansowanemu przez J. Kornaia, i zaprzecza tezie, jakoby budowa teorii i modeli opisujących gospodarkę będącej w stanie permanentnej nierównowagi dawała skuteczne narzędzie do efektywnego zarządzania socjalistyczną gospodarką niedoboru. W to miejsce rozwija natomiast tezę, że gospodarka, która chce utrzymać stabilność, a w konsekwencji żywotność, musi spełniać wymogi ekonomii równowagi, co oznacza, że działające w niej podmioty (przedsiębiorstwa, gospodarstwa domowe i państwo) muszą działać w warunkach twardych ograniczeń budżetowych. Warto podkreślić, że prawdziwość tej teorii potwierdziła się aż nadto w wielu krajach, w tym w Polsce, w latach późniejszych.

W kolejnym nurcie badawczym zainteresowania Profesora kierują się ku funkcjonowaniu rynków finansowych i bankowości. Wynika to niewątpliwie z nabywanego doświadczenia z pracy w radzie nadzorczej Wielkopolskiego Banku Kredytowego S.A., a po połączeniu z Bankiem Zachodnim WBK S.A., w tym także jako przewodniczący tej rady (do 2004 r.) oraz objęcia kierownictwa Zakładu Bankowości i Rynków Finansowych na UW. W tym obszarze Profesor przeprowadził i udostępnił w kraju i za granicą badania nad rekonstrukcją rynkowego systemu finansowego w Polsce, a zwłaszcza polityką antyinflacyjną jako warunku wzrostu gospodarki polskiej oraz napływu stabilnego kapitału zagranicznego. Opisał On również rozwój podmiotów pośrednictwa finansowego oraz rynków finansowych, które umożliwiały bardziej skuteczne metody alokacji oszczędności oraz zapewniały ich przepływ do podmiotów bardziej efektywnych. Zwieńczeniem tej fazy badawczej była obszerna książka wydana przez PWE w 2007 r. pt. Rynkorey system finansowy. Profesor przedstawił $\mathrm{w}$ niej model banku depozytowo-kredytowego wraz z innymi rodzajami pośredników finansowych, takich jak ubezpieczyciele, instytucje pożyczkowe, powiernicy zarządzający funduszami emerytalnymi $\mathrm{i}$ inwestycyjnymi. Monografia ta doczekała się czterech wydań (2007, 2009, 2013, 2018), a w ostatnim została poszerzona o zalecenia Bazylei III i problematykę Europejskiej Unii Bankowej.

Rozwijany ostatnio przez Profesora M. Górskiego kierunek badań ogniskuje się wokół polityki makroekonomicznej. Początkowo opublikował On wyniki badań w artykule pt. Realne stopy zwrotu inwestorów krajowych $i$ zagranicznych w Polsce w latach 1994-2005 zamieszczonym w książce zbiorowej (pod red. M. Duszy, Wydawnictwo Naukowe WZ UW, 2007) pt. Czynniki wzrostu gospodarczego w Polsce. Dalsze wysiłki skoncentrował na polityce fiskalnej i monetarnej w Polsce, a najnowsze badania skupia nad tzw. Nową 
Polityką Strukturalną. W swoich dociekaniach opublikowanych m.in. w artykule pt. Makroekonomiczne skutki polityki fiskalnej i monetarnej w Polsce w latach 1993-2015 umieszczonym w pracy zbiorowej pt. Gospodarka na rozdrożu w XXI w. (Wydawnictwo Naukowe WZ UW, 2015) ocenił stopień ekspansywności i restrykcyjności polityki fiskalnej i monetarnej w poszczególnych podokresach $\mathrm{w}$ całym okresie transformacji polskiej gospodarki. W 2015 r. wydał natomiast artykuł pt. Makroekonomiczne uwarunkowania Nowej Polityki Strukturalnej - przypadek Polski w monografii pt. Nerw Stuctural Economics for Less Advanced Countries (pod red. J. Yifu Lina, A.Z. Nowaka). Obecnie Profesor w ramach koncepcji Nowej Ekonomii Strukturalnej prowadzi badania nad międzynarodowymi przepływami kapitałowymi w sferze bezpośrednich inwestycji zagranicznych w OECD.

Udostępniony przez Profesora dorobek badań naukowych wskazuje na rozległość i głębokość Jago zainteresowań badawczych. Odznacza się spójnością, teoretyczno-modelowym podejściem, aktualnością z silnym powiązaniem z problemami praktyki gospodarczej oraz całościowym ujęciem. Charakterystyczne jest też silne związanie problematyki makro- i mikroekonomicznej oraz ujęć teoretycznych z rozwiązaniami aplikacyjnymi. Jest on oparty na standardach współczesnej wiedzy światowej, a zarazem odpowiada na zapotrzebowanie polskiej gospodarki. Dorobek ten jest też dowodem ogromnej pracowitości Profesora, potwierdzeniem starorzymskiej zasady, że szlachetne umysły karmi praca, a głód poznawczy i ciagłe stawianie nowych pytán są najlepszymi nauczycielami wiedzy, jej pomnażanie zaś - źródłem uzasadnionego zadowolenia.

\section{V}

Spektakularny, ilościowo obszerny, a jakościowo ważki dorobek publikacyjny Profesora dowodzi, że pielęgnuje On zasadę, w myśl której nic tak nie nadaje się do mówienia, jak pisanie. Bo słowo usłyszane przepada, a litera zapisana pozostaje. W okresie 47 lat pracy naukowej i dydaktycznej Profesor opublikował jako autor i współautor 26 książek i monografii naukowych, w kraju i za granica, w języku polskim i angielskim. Książki te wyrastają z ponad 80 publikacji w różnych formach ekspresji naukowej (artykuły, referaty, recenzje, omówienia), licznych ekspertyz i innych materiałów niepublikowanych.

Bogaty i szeroko udostępniony dorobek Profesora zaświadcza, że należy On do tych nielicznych, którzy przykładają się do nauki, by wiedzieć mogli wszyscy. 


\section{VI}

Konfucjusz mawiał, że kto zdobytą wiedzę pielęgnuje, a nową bez ustanku zdobywa, ten może być nauczycielem innych. Znaczące osiągnięcia Profesora na polu edukacji akademickiej i wychowywania młodych pokoleń naukowców zapewne w pełni zadowoliłyby tego wielkiego myśliciela chińskiego.

Profesor Marian Górski prowadzi zajęcia dydaktyczne na wszystkich poziomach kształcenia wyższego, a zwłaszcza na studiach magisterskich i doktoranckich. Jego wykłady, konwersatoria i seminaria obejmują makroekonomię, system finansowy, bankowość czy politykę pieniężną. Aktywnie uczestniczy w kształceniu kadr dla rynków finansowych (maklerów giełdowych, doradców inwestycyjnych i finansowych), wypromował 11 doktorów i ponad 80 magistrów. Jego aktywność jako wykładowcy i nauczyciela rozciąga się poza macierzysty Uniwersytet. Wykładał w uznanych ośrodkach naukowych w USA i Czechach oraz na renomowanych polskich uczelniach.

Zamiłowanie do pracy dydaktycznej z młodzieżą akademicką sprawiło, że już od zarania procesu transformacji ustrojowej w Polsce Profesor aktywnie zaangażował się w reformy programów kształcenia na macierzystej Uczelni. W latach 1990-1996 jako Dziekan Wydziału Zarządzania UW zainicjował gruntowne zmiany programowe na Wydziale. Powstały nowe kierunki i specjalizacje na wszystkich poziomach studiów, a także Executive Program MBA we współpracy z University of Illinois, USA. Do chwili obecnej Profesor kieruje pracami Wydziałowej Komisji Programowej, a od 2002 r. studium doktoranckim. Na poziomie zarządzania Uczelnią uczestniczy $\mathrm{w}$ pracach senatu UW, gdzie przewodniczy Komisji Senackiej ds. Budżetu i Finansów, a od 2008 r. jest członkiem Zarządu Fundacji Uniwersytetu Warszawskiego.

\section{VII}

Szczególną wartością dla Profesora M. Górskiego jest rozwijanie działalności pro publico bono. Od wielu lat angażuje On swój czas, energię i kompetencje w pomnażanie dobra publicznego na różnych niwach społecznych. Charakterystyczną cechą tej aktywności jest uczestniczenie w nurcie reformowania polskiej gospodarki, edukacja ekonomiczna społeczeństwa zgodnie ze standardami światowymi. Niemal od zarania jest aktywnym członkiem Polskiego Towarzystwa Ekonomicznego i Towarzystwa Naukowego Organizacji i Kierownictwa, które to skierowały Go w latach 80. XX wieku do prac Komisji Reformy Gospodarczej. Od lat 90. XX wieku 
jest członkiem European Association of Comparative Studies, gdzie uczestniczy w seminariach i konferencjach, wygłasza referaty i opracowuje ekspertyzy, m.in. na temat szarej strefy gospodarczej w Polsce. Jako były stypendysta Humboldta jest członkiem Societas Humboldtiana Polonarum, a od 2002 r. - członkiem Rady Naukowej miesięcznika „Nasz Rynek Kapitałowy”.

Uczymy się nie dla szkoły, lecz dla życia, jak mawiał Seneka, a działalność Profesora na praktycznym polu gospodarczym jest tego najlepsza egzemplifikacją. Stynna maksyma b. prezydenta USA B. Clintona: „Po pierwsze gospodarka!” jest imperatywem, jaki zawsze przyświecał Profesorowi w Jego poczynaniach jako działacza gospodarczego. Już na początku lat 90. XX wieku współzałożył firmę doradczą PREMIUM, która wykonała wiele ekspertyz związanych z prywatyzacją, restrukturyzacją i strategią rozwoju działających wówczas przedsiębiorstw. W tym okresie opracował jako ekspert Ministra Gospodarki szereg opinii o ustawach dotyczących wspierania finansowego inwestycji. Od 1994 r. jest członkiem zespołu ekspertów Ministra Edukacji Narodowej ds. oceny funkcjonowania szkół wyższych w dziedzinie zarządzania, a od 2002 r. członkiem Rady ds. Dobrych Praktyk Gospodarczych przy Prezesie Urzędu Ochrony Konkurencji i Konsumentów. Zajmuje się tam problemami ochrony najsłabszych uczestników rynku. Jest członkiem-założycielem Polskiego Instytutu Dyrektorów promującego Zasady Ładu Korporacyjnego (od 2003 r.). W latach 2013-2017 z ramienia Komisji Nadzoru Finansowego był członkiem rady WIBOR ds. nadzoru organizatora i agenta kalkulacyjnego rynku niezabezpieczonych depozytów międzybankowych. Od lat 90. XX wieku do czasów najnowszych był członkiem rad nadzorczych wielu spółek publicznych i niepublicznych, m.in. BZ WBK S.A., Towarzystwa Ubezpieczeniowego WARTA S.A.

\section{VIII}

Przy chęci podsumowania lat 1971-2018, a więc okresu dotychczasowego przebiegu kariery zawodowej i powstawania całokształtu dorobku Profesora, nasuwa się nieodparcie wniosek, że Jego owocne dzieło wyrasta z pięciu atrybutów. Po pierwsze, z głębokiego i wszechstronnego wykształcenia zdobytego na Uniwersytecie Warszawskim i w prestiżowych ośrodkach akademickich za granica. Po drugie, z lojalności i przywiązania do macierzystej Uczelni, której od 1971 r. oddał niemal całe życie zawodowe, talenty i pracowitość. Po trzecie, z konsekwencji w rozwijaniu zainteresowań badawczych koncentrujących się na makroekonomicznych uwarunkowaniach równowagi 
gospodarczej, później na funkcjonowaniu rynków finansowych i bankowości, a współcześnie na polityce makroekonomicznej. Po czwarte, z zamiłowania do dydaktyki, rozwoju i promocji młodych kadr. Wreszcie, last but not least, z doświadczenia praktycznego zebranego na różnych polach, w tym eksperta instytucji centralnych, konsultanta przedsiębiorstw i członkostwa w radach nadzorczych spółek akcyjnych ważnych dla gospodarki narodowej.

\section{IX}

Od początku kariery zawodowej Profesor Marian Górski miał odwagę być mądrym. Wydaje to ciągle smaczne i pożyteczne owoce. Wszak odwagę tę zawsze łączył z przestrogą Sokratesa o ograniczoności poznawczej homo sapiens, albowiem ma świadomość, że wielu wie dużo, a nikt wszystkiego. Sprawia to, że na całej przestrzeni swej pracowitej i twórczej działalności Jego odwadze towarzyszyła zawsze pokora. Profesor nie dbał o tanie publiczne poklaski, nie zabiegał o wystawianie Go na afisz. Jeśli starał się wywyższać, to tylko nad czymś, nigdy zaś nad kimś. Owe wywyższanie polegało na stale podejmowanych próbach okiełznania niewiedzy, lepszego pojmowania rzeczywistości, wysuwania hipotez i ich weryfikacji. W swoich poczynaniach wiedział, że prawdziwa wartość obroni się sama. Prawdziwa nauka nie potrzebuje bowiem kokieterii, a jej rzeczywiste walory i pożytki materializują się w dobroczynnych działaniach tych, którzy dzięki niej podnieśli sprawność swego rozumu i jakość swoich czynów. Czynienie świata lepszym, urządzanie go wedle rozumnej wiedzy jest więc wyrazem najwyższej aprobaty, jaką może uzyskać ten, kto ma odwagę być mądrym. Aprobata ta z pewnością przynależy Profesorowi Marianowi Górskiemu. 


\title{
RZECZPOSPOLITA POLSKA \\ MINISTER FINANSÓW
}

\author{
Pan \\ prof. zw. dr hab. \\ Marian Górski \\ Kierownik \\ Katedry Systemów \\ Finansowych Gospodarki \\ oraz \\ Zakładu Bankowości \\ i Rynków Pieniężnych \\ Wydziału Zarządzania \\ Uniwersytetu Warszawskiego
}

Szanowny Panie Profesorze,

$z$ okazji jubileuszu 70-lecia urodzin, proszę przyjąć serdeczne gratulacje $i$ życzenia dalszych sukcesów w pracy naukowej $i$ dydaktycznej.

Przy tej okazji pragnę złożyć podziękowanie za trud i zaangażowanie w działania podjęte przez lata na rzecz naszej Alma Mater.

W trakcie dotychczasowej drogi naukowej $i$ zawodowej wnióst Pan Profesor nieoceniony wkład w rozwój nauk z zakresu ekonomii. Stąd też, pozwalam sobie wyrazić nadzieję, że Pańska wiedza i doświadczenie stużyć będq kolejnym pokoleniom.

Wielce dostojny Jubilacie! Jeszcze raz proszę o przyjęcie najszczerszych życzeń zdrowia, wszelkiej pomyślności, radości i satysfakcji w życiu osobistym i zawodowym.

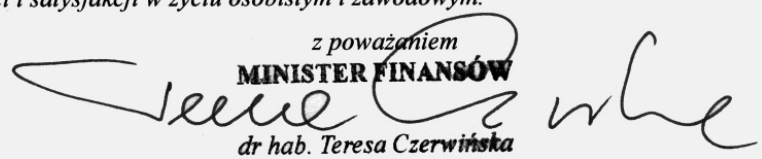

ul. Świętokrzyska 12, 00-916 Warszawa | tel.: +48 226945555 | e-mail: kancelaria@mf.gov.pl 


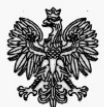 \\ MINISTERSTWO NAUKI \\ I SZKOLNICTWA WYŻSZEGO \\ PODSEKRETARZ STANU \\ Sebastian Skuza}

Warszawa, 3 lipca 2018 r.

\section{Szanowny Pan}

Prof. dr hab. Marian Górski

Wydzial Zarządzania

Uniwersytet Warszawski

Szanowny Panie Profesorze,

pragnę wyrazić najserdeczniejsze podziękowanie za wkład w rozwój nauki i szkolnictwa wyższego. Ponad 40-letnie zaangażowanie Pana Profesora w prace na rzecz Wydziału Zarządzania Uniwersytetu Warszawskiego znajduje swoje odzwierciedlenie w Jego dzisiejszej pozycji, zarówno w obszarze działalności dydaktycznej, jak też naukowej.

Wkład Pana Profesora w promocję pokoleń młodych naukowców jest bezcenny. Osobiście jako adiunkt w Katedrze Systemów Finansowych Gospodarki miałem możliwość korzystania $\mathrm{z}$ wiedzy, doświadczenia oraz wsparcia Pana Profesora, szczególnie istotnego w procedurze ubiegania się o kolejny stopień naukowy.

Poza osiągnieciami w obszarze nauki i szkolnictwa wyższego niezmiernie istotne było zaangażowania Pana Profesora $\mathbf{w}$ proces transformacji ustrojowej życia gospodarczego w naszym kraju po 1989 r. Wiedza i doświadczenie Pana Profesora zdobyte podczas staży naukowych w uznanych zagranicznych ośrodkach akademickich stanowily nieocenioną wartość dodaną w tworzeniu systemu gospodarki rynkowej.

Dzisiejszy Jubileusz może stanowić okazję do refleksji i podsumowania, jednak przedwczesne byłoby stwierdzenie o uwiecznieniu kariery zawodowej Pana Profesora. Wiedza i doświadczenie Pana Profesora nadal powinny służyć nauce i szkolnictwu wyższemu, zwłaszcza $\mathrm{w}$ kontekście wyzwania związanego $\mathrm{z}$ aktualnie toczącym się systemowym procesem reformy tego niezmiernie ważnego obszaru.

Życzę Panu Profesorowi dalszych sukcesów zawodowych oraz wszelkiej pomyślności w życiu osobistym.

Z wyrazami szacunku,

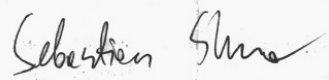


Warsaw, $12^{\text {th }}$ September 2018

\author{
Mr. Marian Górski \\ Department of Financial Systems \\ Faculty of Management \\ Warsaw University \\ Dear Professor Górski, \\ Dear Marian,
}

On behalf of the Management and the Board of Directors of the Bank Zachodni WBK S.A., I. am honored to have this opportunity to send you best wishes on this wonderful anniversary of your 70th birthday. We wish you the very best and every happiness.

As you celebrate this moment, we hope you also reflect on the many years you worked for the Wielkopolski Bank Kredytowy and later the BZ WBK. We respectfully honor not only your extensive knowledge but also your experience contribution, loyalty, and support.

But your merits go well beyond your work with us. It is to be stressed that as a practitioner and scholar you had contributed to the development of Polish banking system, stimulated advance of corporate governance standards and had the enormous impact on the education of many leaders of our sector. 1 am fully aware that this was already recognized by the academia and Polish authorities, but it must be underlined and appreciated once more.

Let me also add my personal and warmest congratulation to the many you will receive from your family and friends. May your day be filled with happy memories and bright hopes.

Happy 70 th birthiday!

Warm regards,

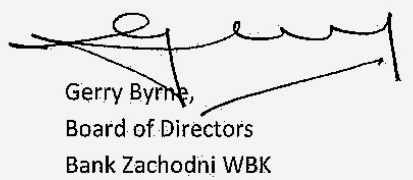





\section{O Jubilacie}

Profesor Marian Górski urodził się 12 września 1948 roku w Augustowie. Tam też przeszedł proces edukacji na poziomie szkoły podstawowej i średniej. W roku 1966 rozpoczął studia na Wydziale Ekonomii Politycznej Uniwersytetu Warszawskiego, na kierunku ekonometria. Po wydarzeniach marcowych 1968 roku, których Profesor był aktywnym uczestnikiem, działalność Wydziału została zawieszona (Wydział wznowił swoją działalność pod nazwą Wydział Nauk Ekonomicznych).

Pracę magisterską pt. Triangulizacja macierzy przeptywów międzygatęziowych Jubilat napisał pod kierunkiem prof. dr hab. Tadeusza Kasprzaka. Zaproponował w niej szereg oryginalnych algorytmów dekompozycji, w tym triangulizacji, macierzy przepływów międzygałęziowych. Po ukończeniu w roku 1971 studiów na Wydziale Nauk Ekonomicznych UW na kierunku ekonometria został przyjęty na staż asystencki. Promotor zaproponował $\mathrm{Mu}$ wspólną publikację, której istotną częścią miała być poprawiona i uzupełniona praca magisterska. Książka Studium struktur gospodarczych Polski została wydana przez PWN w roku 1976. Autorzy uzyskali za nią nagrodę Ministra Nauki i Szkolnictwa Wyższego oraz wyróżnienie w prestiżowym wówczas konkursie im. Oskara Lange, organizowanym przez Polskie Towarzystwo Ekonomiczne.

W roku 1972 Profesor został zatrudniony na stanowisku asystenta w nowo powstałym Wydziale Zarządzania UW (wówczas Instytucie) w Zakładzie Konsumpcji i Rynku, kierowanym przez prof. dr. hab. Kazimierza Rycia. Od tego momentu brał On udział w licznych badaniach prowadzonych w tym Zakładzie, które były realizowane głównie na zlecenie i we współpracy z Instytutem Handlu Wewnętrznego i Konsumpcji. Ich efektem była, napisana pod kierunkiem prof. Rycia i obroniona w 1978 roku, praca doktorska pt. Konsumpcja w planistycznych modelach wzrostu gospodarki socjalistycznej. Analizując rolę konsumpcji jako zmiennej makroekonomicznej w optymalizacyjnych modelach wzrostu, wykazał On, że brak satysfakcjonujących rezultatów w tym zakresie w praktyce gospodarczej wynika m.in. $\mathrm{z}$ traktowania 
jej jako zmiennej maksymalizowanej - jednak rezydualnej. Korzystniejsze dla poziomu konsumpcji w gospodarce realnej mogłoby być przejście od formuły optymalizacji maksymalizującej do optymalizacji satysfakcjonującej. Praca doktorska została wydana przez PWN w roku 1982 i uzyskała nagrodę Ministra Nauki i Szkolnictwa Wyższego.

W roku 1974 Profesor Marian Górski ożenił się z Grażyną Sosnowską, koleżanką ze studiów. Jest ojcem dwóch synów: Marcina (1975), który ukończył Wydział Architektury Politechniki Warszawskiej i pracuje jako adiunkt na tym Wydziale oraz Michała (1978), który ukończył Wydział Zarządzania UW i pracuje jako menedżer w korporacji Black, Red, White. Jest również szczęśliwym dziadkiem czwórki wnucząt.

Po obronie pracy doktorskiej oraz objęciu stanowiska adiunkta Jubilat kontynuował badania w zespole Zakładu Konsumpcji i Rynku, przekształconym w roku 1982 w Katedrę Gospodarki Narodowej, w coraz większym stopniu samodzielnie, przejmując niekiedy rolę kierownika grupy badawczej. $\mathrm{Na}$ początku lat osiemdziesiątych wraz z całym zespołem aktywnie uczestniczył nad pracami związanymi z reformą gospodarczą. Powstały wtedy, napisany z wspólnie z K. Ryciem, rozdział pt. Problemy i kierunki stabilizacji gospodarki do książki pt. Drogi $i$ dylematy reformy gospodarczej (1981), wspólne z G. Jędrzejczakiem i K. Ryciem artykuły publikowane w „Życiu Gospodarczym” (1981-1982), „Wektorach” (1982) czy „Przeglądzie Technicznym” (1982-1983) oraz raporty z badań realizowanych na zlecenie IHWiK oraz TNOiK. Jednocześnie w coraz większym stopniu interesował się On makroekonomicznymi aspektami równowagi gospodarczej i analizą przejawów jej braku w gospodarce centralnie planowanej.

W roku 1981, doktor wówczas, Marian Górski zaangażował się czynnie w aktywność w ruchu Solidarność, został wybrany do Komisji Zakładowej NSZZ Solidarność na Uniwersytecie Warszawskim. Aktywnie uczestniczył również $\mathrm{w}$ animacji powstającego wówczas w Polsce ruchu konsumenckiego. Jako członek Federacji Konsumentów został wybrany sekretarzem Społecznej Komisji Cen. Komisja ta prowadziła i publikowała m.in. notowania cen targowiskowych w Polsce.

W roku 1983 odbył ośmiomiesięczny staż na Carleton University w Ottawie (Kanada). Okres ten poświęcił głównie studiom nad makroekonomicznymi modelami równowagi gospodarczej oraz inflacją jako przejawem braku równowagi w gospodarce rynkowej.

Od roku 1984 w coraz większym stopniu współpracował w badaniach z dr. Grzegorzem Jędrzejczakiem. Początkowymi efektami tej współpracy były raporty ze wspólnych badań np. Inflacja w warunkach reformy gospodar- 
czej (1985, na zlecenie Towarzystwa Naukowego Organizacji i Kierowania), Systemowe $i$ zasileniowe uwarunkowania równowagi rynkowej gospodarki socjalistycznej (1985, na zlecenie Instytutu Rynku Wewnętrznego i Konsumpcji), Program doskonalenia pieniężnych mechanizmów gospodarczych (1985, na zlecenie TNOiK). Posumowaniem tych badań była ich wspólna książka pt. Równowaga $i$ stabilność w gospodarce socjalistycznej wydana przez PWN w roku 1987. Odpowiednie rozdziały napisane przez każdego z nich były podstawą dwóch przewodów habilitacyjnych.

W pracy tej poszukiwali odpowiedzi na pytanie: jakie warunki musiałaby spełniać gospodarka centralnie planowana, by móc charakteryzować się zrównoważeniem i stabilnością? „W gospodarce socjalistycznej regulowanej przez hierarchiczny plan pożądany stan gospodarki (swoiście rozumiana równowaga gospodarki) jest wyznaczany przez pozaekonomiczne normy systemu społecznego. Normy te ustalane za pomocą przetargów o charakterze społecznym i politycznym, w końcu przybierają postać planu centralnego. Gospodarcza działalność podmiotów sprowadza się wtedy albo do realizacji zadań planu (przedsiębiorstwa), albo do korzystania z jego efektów (gospodarstwa domowe). W pracy tej próbujemy inaczej spojrzeć na równowage gospodarki socjalistycznej i na jej mechanizmy stabilizacyjne. Punktem wyjścia jest założenie autonomiczności podmiotów gospodarczych wyrażających swoje wewnętrzne interesy ekonomiczne i realizujących je przy określonych przez system gospodarczy ograniczeniach budżetowych" (ibidem, s. 5).

Książka ta w sposób wyraźny i jednoznaczny przeciwstawiała się dość powszechnemu wówczas nurtowi ekonomii nierównowagi, zapoczątkowanemu przez znaną książkę J. Kornaia pt. Antyequilibrium.

Marian Górski lata 1988-1989 spędził wraz z rodziną na Universität Hamburg jako stypendysta fundacji Humboldta. Będąc aktywnym uczestnikiem seminarium prof. J. Schenka, z jednej strony kontynuował badania nad stanem gospodarki polskiej, z drugiej zaś - studiował problematykę funkcjonowania systemu finansowego kapitalistycznej gospodarki rynkowej. Efektem pierwszego nurtu badań był m.in. artykuł pt. The scale of disequilibrium on the consumer market and sources of price inflation in Poland. Empirical evidence for the 1980s zamieszczony w Nr 2 "Jahrbuch der Wirtschaft Osteuropas” z 1989 roku. Studia w drugim nurcie tworzyły podstawy teoretyczne do realizacji nowych zadań w Polsce.

Po powrocie, poza kontynuacją pracy na Wydziale Zarządzania, Profesor został zatrudniony na stanowisku profesora nadzwyczajnego w Instytucie Finansów, gdzie głównie kontynuował prace badawcze. Ich efektem był m.in. udział w przygotowaniu kwartalnych i rocznych raportów o stanie 
gospodarki oraz referaty na doroczne konferencje organizowane przez Instytut. Jeden $\mathrm{z}$ nich pt. Makroekonomiczne wwarunkowania $i$ skutki polityki stabilizacyjnej w Polsce, napisany wraz z D. Jaszczyńskim, został zamieszczony w pracy zbiorowej pt. Polityka finansowa, stabilizacja, transformacja (1991). Efektem tego okresu badawczego był również artykuł pt. Prices, incomes and the consumer market $\mathrm{w}$ opublikowanej w Anglii w pracy zbiorowej pt. Poland into the 1990s. Economy and Society in Transition (1991) oraz artykuł pt. Hyperinflation and Stabilization in Poland w opulikowanej w Stanach Zjednoczonych książce zbiorowej pt. Organizational Communication and Management. Global Perspective (1993).

$\mathrm{Na}$ początku lat dziewięćdziesiątych trzy fakty wywarly niewątpliwy wpływ na karierę Mariana Górskiego i jego dalsze prace badawcze: objęcie funkcji Dziekana Wydziału Zarządzania (1990-1996); założenie wraz z dwoma partnerami spółki consultingowej PREMIUM-econ Sp. z o.o. (1991-1998) oraz wybór na członka rady nadzorczej Wielkopolskiego Banku Kredytowego S.A. (1991-2005). Pierwszy fakt, ze względu na zwielokrotnione obciążenia administracyjne, musiał niewątpliwie osłabić jego aktywność badawczą. Funkcja partnera i starszego konsultanta nadała jego badaniom wymiar bardziej praktyczny i aplikacyjny, natomiast członkostwo w radzie nadzorczej banku, a następnie jej przewodniczenie (od 1995 r.), było nieocenionym źródłem wiedzy praktycznej z zakresu funkcjonowania sektora bankowego, którą wykorzystywał na bieżąco w swojej pracy dydaktycznej i w późniejszych publikacjach.

W latach 1990-1996 pełnił przez dwie kadencje funkcję Dziekana Wydziału. Trudności w zarządzaniu Wydziałem w owym okresie wynikały $\mathrm{z}$ bardzo ograniczonych środków finansowych z budżetu państwa, wzrastającej konkurencji na rynku ze strony nowo powstających uczelni niepublicznych oraz konieczności przystosowania się do nowych rynkowych zasad finansowania działalności naukowej i dydaktycznej Wydziału. W okresie tym został gruntownie zreformowany program prowadzonych tradycyjnie na Wydziale magisterskich studiów stacjonarnych. Przygotowano programy nowych studiów, w tym Dyplomowych Studiów Menedżerskich i dwuletnich Magisterskich Studiów Menedżerskich. Studia te znacząco wzbogaciły ofertę dydaktyczną Wydziału, ale przede wszystkim były prekursorskie wobec realizowanego wtedy dwustopniowego systemu bolońskiego. Studia te prowadzone w trybie zaocznym i wieczorowym stały się istotnym strumieniem dochodów pozabudżetowych Wydziału. Dochody te pozwoliły zaś na poprawę bazy materialnej Wydziału, remonty budynków, wyposażenie w sprzęt informatyczny itd. W roku 1992, we współpracy z University of Illinois (USA), został urucho- 
miony Program Executive MBA, który zajmuje tradycyjnie już pierwsze miejsce $\mathrm{w}$ polskich rankingach tego typu studiów. Jako Dziekan Wydziału przez dwie kadencje był członkiem Senatu Uniwersytetu Warszawskiego oraz aktywnym członkiem Komisji Budżetowej Senatu.

Jubilat aktywnie uczestniczył również w wymianie międzynarodowej w roku 1992 ukończył czterotygodniowy kurs Advanced Executive Programme organizowany przez Kellogg's School of Northwestern University (Chicago, USA); w 1993 r. - sześciotygodniowy kurs Financial System in the Market Economy organizowany przez Wharton School of Pennsylvania University (Philadephia, USA).

Po odejściu w 1991 roku z Instytutu Finansów założył, wraz z dwoma partnerami, spółkę consultingową PREMIUM-econ, a napisany wspólnie z D. Jaszczyńskim i M. Breitkopfem raport pt. Prywatyzacja w Polsce (1991) został opublikowany $\mathrm{w}$ języku polskim $\mathrm{i}$ angielskim przez fundację im. Fridricha Eberta. W ramach spółki kierował zespołami doradców w projektach prywatyzacyjnych (CORA Garwolin S.A i POLOMO Praszka S.A.) i restrukturyzacyjnych (DEKORA S.A. w Żarach i Zakłady Obuwnicze w Złotoryi). Na zlecenie Ministra Przemysłu i Handlu przygotował raporty o skutkach społeczno-ekonomicznych utworzenia Specjalnych Stref Ekonomicznych w Mielcu i Wałbrzychu oraz przygotował projekt utworzenia Agencji Techniki i Technologii specjalizującej się we wspieraniu $\mathrm{w}$ imieniu państwa inwestycji typu venture capital. Na zlecenie FIAT Auto Poland S.A oraz POLMOT Holding S.A opracowywał, wraz z J. Rajskim, w cyklu kwartalnym krótko- średnio- i długoterminowe prognozy makroekonomiczne. Jednym z trudniejszych, ale zarazem o największych skutkach praktycznych, był zrealizowany w roku 1996 projekt AVIS. W ramach którego, na zlecenie Ministra Przemysłu i Handlu, koordynował Profesor pracami resortów rządowych w wypełnianiu kwestionariusza przed akcesją Polski do Unii Europejskiej. Kwestionariusz oceniał w szczególności stopień spełnienia przez Polskę wymogów i warunków członkostwa, zdolność do przyjęcia regulacji wspólnotowych oraz wyniki gospodarcze w ostatnich trzech latach. W latach późniejszych, po wyjściu ze spółki PREMIUM-econ, jako ekspert Ministerstwa Gospodarki, przygotował szereg ekspertyz, w tym opinie o ustawach o wspieraniu finansowym inwestycji.

Przez cały okres swojej aktywności zawodowej Profesor Górski starał się łączyć pracę badawczo-dydaktyczną na Wydziale Zarządzania UW z aktywnością w sferze społeczno-gospodarczej. W latach 90. XX wieku poza pracą ekspercką w PREMIUM-econ, był członkiem i przewodniczącym w kilku radach nadzorczych: członkiem Rady Nadzorczej Wielkopolskiego 
Banku Kredytowy S.A. (1991-1995), przewodniczącym RN Banku Zachodniego WBK S.A. (1995-2005), zastępcą przewodniczącego RN CORA Garwolin S.A. (1995-1999), przewodniczącym RN Polskiego Monopolu Loteryjnego sp. z o.o. (1999-2004), przewodniczącym RN Centrum Naukowo Produkcyjnego Materiałów Elektronicznych CeMat 70 S.A. (1997-2006), członkiem RN Powszechnego Towarzystwa Emerytalnego „Warta” S.A. (2010-2015).

W roku 1994 Profesor Marian Górski został powołany na członka zespołu ekspertów Ministra Edukacji Narodowej i był nim do roku 2013. W latach dziewięćdziesiątych funkcja ta wiązała się m.in. z oceną funkcjonowania szkół wyższych w dziedzinie zarządzania, wynikającą z nadzorczych funkcji Ministra. Następnie zespół opiniował wnioski ośrodków akademickich w sprawie przyznania nagrody Ministra oraz wnioski o dofinansowanie podręczników akademickich.

Działalność badawczą w latach 90. poza Uniwersytetem realizował Profesor, będąc m.in. członkiem European Asssosiation of Comparative Economic Studies (EACES). Przygotowywał referaty na coroczne konferencje tego towarzystwa oraz opracował na jego zlecenie ekspertyzę o tzw. szarej strefie gospodarczej w Polsce. Po powrocie ze stypendium Humboldta nadal utrzymywał kontakty naukowe z fundacją oraz innymi byłymi stypendystami jako członek Societas Humboldtiana Polonarum.

W latach dziewięćdziesiątych prowadził również na szeroką skalę szkolenia dla polskich przedsiębiorstw i agend rządowych oraz na zlecenie organizacji międzynarodowych, m.in. Banku Światowego. Wykładał na kursach dla maklerów giełdowych i doradców inwestycyjnych organizowanych przez Centrum Prywatyzacji. W latach 1993-2005 był członkiem komisji egzaminacyjnej przy Ministrze Skarbu dla kandydatów na członków rad nadzorczych w spółkach z udziałem Skarbu Państwa, a w latach 1998-2000 - członkiem Rady Konsultacyjno-Programowej do spraw szkoleń i egzaminów dla kandydatów na członków rad nadzorczych przy Ministrze Skarbu Państwa. W tym czasie opracował program szkoleń oraz zestaw pytań egzaminacyjnych z zakresu rynków finansowych.

W latach 2013-2017 Profesor Marian Górski był delegowanym przez Przewodniczącego Komisji Nadzoru Finansowego członkiem Rady WIBOR, która nadzorowała organizatora i agenta kalkulacyjnego rynku niezabezpieczonych depozytów międzybankowych.

Doświadczenie bankowe oraz studia sytuacji makroekonomicznej kraju po raz pierwszy wykorzystał $\mathrm{w}$ artykule pt. The new banking and financial sector: its role, potential and weaknesses w, opublikowanej w Anglii, książce 
zbiorowej pt. Poland into New Millenium (2001). Kierowanie Zakładem Bankowości i Rynków Finansowych oraz doświadczenie z pracy w radzie nadzorczej kierunkowały jego zainteresowania naukowe w coraz większym stopniu na obszar zarządzania instytucjami pośrednictwa finansowego, w tym w szczególności banków. W roku 2005 Profesor Górski zredagował zeszyt 2 „Problemów Zarządzania” poświęcony pośrednikom finansowym. Dużą część materiałów do tego zeszytu złożyli jego doktoranci. Sam opublikował artykuł pt. Architektura systemu pośrednictwa finansowego, w którym po raz pierwszy sformułował ogólny model pośrednika finansowego. W tym samym roku wydał książkę pt. Architektura systemu finansowego gospodarki.

Poza stałym zgłębianiem wiedzy na temat funkcjonowania coraz szerszego grona pośredników finansowych w Polsce, aktualne zainteresowania badawcze Profesora Mariana Górskiego wynikają z doświadczeń makroekonomisty. Empirycznie weryfikuje On wykorzystywane w dydaktyce modele makroekonomiczne na bazie danych statystycznych z gospodarki polskiej. Rezultatem tych zainteresowań jest m.in. artykuł pt. Egzemplifikacja wybranych modeli makroekonomicznych w gospodarce polskiej wo okresie 19932005 zamieszczony w pracy zbiorowej pt. Fenomen transformacji. Próba analizy (2005), w którym analizuje praktyczną stosowalność w naszych warunkach takich modeli, jak: Okuna, Philipsa, IS-LM. Innym efektem tego nurtu badawczego jest artykuł pt. Makroekonomiczne skutki polityki fiskalnej i monetarnej w Polsce w latach 1993-2005 opublikowany w książce pt. Zrównoważony wzrost gospodarczy. Rola polityki finansowej. Polska droga do euro (2006) oraz artykut pt. Impact of fiscal and monetary policy on the economic growth in Poland in the years 1993-2005 opublikowany w pracy zbiorowej pt. Reinventig Poland. Economic and political transformation and evolving national identity wydanej w Stanach Zjednoczonych przez Basees/ Routledge Serries on Russian and East European Studies, New York (2008).

Tytuł profesora nauk ekonomicznych Jubilat uzyskał w roku 2007. Jedną z głównych pozycji bibliograficznych w ocenie dorobku była książka profesorska pt. Rynkowy system finansowy wydana przez PWE w 2007 roku. W pracy tej $\mathrm{w}$ sposób kompleksowy i systematyczny zaprezentował wszechstronne aspekty funkcjonowania współczesnych systemów finansowych na poziomie gospodarki krajowej, ze szczególnym uwzględnieniem ewolucji i obecnego kształtu tego systemu w Polsce. Analiza prowadzona była $\mathrm{w}$ trzech przekrojach: instrumentów, podmiotów i rynków finansowych. Monografia doczekała się w Polskim Wydawnictwie Ekonomicznym 4 wydań $(2007,2009,2013,2018)$. Każde wydanie było zmienione i uzupełnione, dość wspomnieć, że pierwsze wydanie liczyło 338 stron - ostatnie 
zaś 400. Wydanie z 2018 r. uwzględnia zalecenia Bazylei III i problematykę Europejskiej Unii Bankowej.

W roku 2015 Jubilat opublikował artykuł pt. Makroekonomiczne skutki polityki fiskalnej i monetarnej w Polsce w latach 1993-2015 w pracy zbiorowej pt. Gospodarka na rozdrożu XXI wiek wydanej przez Wydawnictwo Naukowe Wydziału Zarządzania Uniwersytetu Warszawskiego. Ocenił w nim stopień ekspansywności i restrykcyjności polityki fiskalnej i monetarnej w poszczególnych podokresach w całym okresie transformacji.

W roku 2017 Profesor opublikował artykuł pt. Makroekonomiczne uwarunkowania Nowej Polityki Strukturalnej - przypadek Polski w wydanej dwujęzycznej (w językach polskim i angielskim) pracy zbiorowej pt. Nowa Ekonomia Strukturalna wobec krajów mniej zaawansowanych (New Stuctural Economis for Less Advenced Contries) zredagowanej przez Justina Yifu Lina, twórcy koncepcji Nowej Ekonomii Strukturalnej, i Alojzego Z. Nowaka. Ta międzynarodowa współpraca ma być kontynuowana w kolejnej wspólnej publikacji, do której przygotowuje artykuł o międzynarodowych przepływach kapitałowych w ramach bezpośrednich inwestycji zagranicznych w ramach OECD.

Od roku 2009 Profesor Marian Górski jest kierownikiem Katedry Systemów Finansowych Gospodarki i Zakładu Bankowości i Rynków Pieniężnych w tej Katedrze. Wypromował 11 doktorów oraz ponad 80 magistrów na kierunku Finanse i Rachunkowość. Wykłada obecnie: System Finansowy Gospodarki, Bankowość i Politykę Pieniężną. W latach 2007-2011 kierował na Wydziale Zarządzania Uniwersytetu Warszawskiego studiami doktoranckimi.

Od roku 2010 jest członkiem Kapituły przyznającej nagrody dla referatów zgłaszanych na Kongres Rynków Kapitałowych organizowany przez Krajowy Depozyt Papierów Wartościowych (KDPW) i Wydział Zrządzania UW.

W ciągu lat 2011-2019 jest wybranym przez elektorów Uniwersytetu Warszawskiego członkiem Senatu Uniwersytetu i przewodniczy Komisji Senackiej ds. Budżetu i Finansów. 


\section{Wykaz najważniejszych publikacji}

Studium struktur technicznych gospodarki Polski, (współautor: T. Kasprzak), „Gospodarka Planowa” 1972, nr 2.

Analiza dynamiki ptac $i$ wydajności pracy w przemyśle polskim w latach 192-1970, w: pracy zbiorowej pt. Ekonomiczne i spoteczne problemy spożycia, Ossolineum, Wrocław 1976.

Denaturalizacja spożycia na wsi (współautorzy: R. Głowacki, K. Ryć), Instytut Rozwoju Wsi i Rolnictwa, Warszawa 1976.

Studium struktur gospodarczych Polski (współautorzy: H. Góralska, T. Kasprzak), PWN, Warszawa 1976.

Problemy funkcjonowania systemu ochrony interesów konsumentów w Polsce, „Roczniki Instytutu Handlu Wewnętrznego i Usług” 1978, nr 2.

Analiza struktury technicznej gospodarki (współautor: T. Kasprzak), w: pracy zbiorowej pt. Metody cybernetyczne w zarządzaniu, Ossolineum, Wrocław 1979.

Wybrane problemy konstrukcji funkcji kryterium optymalizacyjnych modeli wzrostu gospodarki narodowej, „Prace Naukowe Akademii Ekonomicznej im. O. Lange we Wrocławiu" 1980, nr 164.

Analysis of the Technological Structure of Economy (współautor: T. Kasprzak), „Oeconomica Polona” 1980, nr 2.

Którędy do stabilizacji (współautor: K. Ryć), „Życie Gospodarcze” 1981, nr 11.

Polityka trudnego pieniądza (współautor: K. Ryć), „Życie Gospodarcze” 1981, nr 12.

Niech pieniadz znaczy pieniądz (współautor: K. Ryć), „Życie Gospodarcze” 1981, nr 13.

Problemy i kierunki stabilizacji gospodarki (współautor: K. Ryć), w: pracy zbiorowej pt. Drogi i dylematy reformy gospodarczej, PWE, Warszawa 1981.

Dynamika cen towarów $i$ ustug w świetle zmian dochodów $i$ zasobów pieniężnych ludności w 1982 r. (współautorzy: G. Jędrzejczak, M. Misiak, K. Ryć), „Prace i Materiały Zakładu Badań Cen” 1982, nr 68.

Między stusznymi celami a inflacją (współautorzy: G. Jędrzejczak, K. Ryć), „Życie Gospodarcze" 1982, nr 43.

Konsumpcja w planistycznych modelach wzrostu gospodarki socjalistycznej (praca doktorska), PWN, Warszawa 1982. 
Aktualne uwwarunkowania nierównowagi rynkowej (współautor: G. Jędrzejczak), „Rocznik Instytutu Rynku Wewnętrznego i Konsumpcji”, 1983.

Sytuacja gospodarstwe domowych w kontekście inflacyjnej polityki cenowej, „Biuletyn Federacji Konsumentów" 1983, nr 3.

Stagflacja (współautor: G. Jędrzejczak), „Wektory” 1983, nr 2.

Dynamika cen towarów $i$ ustug w świetle zmian dochodów $i$ zasobów pieniężnych ludności w 1983 roku (scenariusze) (współautorzy: G. Jędrzejczak, K. Ryć), „Prace i Materiały Zakładu Badań Cen” 1983, nr 72.

Podaż $i$ popyt w warunkach inflacji (współautor: G. Jędrzejczak), „Materiały Informacyjne Urzędu Cen” 1983, maj.

Akcje, obligacje i frustracje (współautor: G. Jędrzejczak), „Przegląd Techniczny” 1983, nr 12.

Inflacyjne zagrożenia reformy (współautor: G. Jędrzejczak), „Przegląd Techniczny” 1983, nr 5.

Jaki scenariusz wybierzemy? (współautor: G. Jędrzejczak), „Życie Gospodarcze” 1983, nr 12.

Podmioty gospodarki w warunkach inflacyjnego wzrostu cen, „Materiały Informacyjne Urzędu Cen” 1983, nr 3.

Inflacja - źródta $i$ objarey (współautor: G. Jędrzejczak), cykl artykułów publikowanych w: „Przeglądzie Technicznym” 1982, nr 9-10; 1983, nr 1-4.

Wskaźniki kontroli statystycznej ruchu cen i ptac dla potrzeb prognoz ostrzegarwczych, „Prace i Materiały Zakładu Badania Cen” 1984, nr 3.

Mechanizm inflacyjny w gospodarce planowej $i$ elementy antyinflacyjnej polityki pieniężnej (współautor: G. Jędrzejczak), „Prace i Materiały Zakładu Badań Cen” 1984, nr 75.

Równowaga $i$ stabilność w gospodarce socjalistycznej (współautor: G. Jędrzejczak), rozprawa habilitacyjna, PWN, Warszawa 1987.

Symulacyjny model inflacji kosztowej SMIK - 1 (współautorzy: G. Jędrzejczak, J. Zarajczyk), „Prace i Materiały Zakładu Badań Cen” 1987, nr 35.

Porównanie procesów inflacyjnych w Polsce i na Wegrzech w latach 1980-1985 (współautor: E. Wróbel), „Kwartalnik Naukowy Wydziału Zarządzania UW” 1988, nr 1.

Drugi rynek jako proces przystosowawczy niezrównoważonego rynku dóbr i ustug konsumpcyjnych, „Kwartalnik Naukowy Wydziału Zarządzania UW” 1988, nr 1.

The scale of Disequilibrium on the Consumer Market and Sources of Price Inflation in Poland. Empirical Evidence for 1980's, "Jahrbuch der Wirtschaft Osteuropas" 1989, nr 2.

Analiza $i$ prognoza zjarwisk inflacyjnych (współautor: D. Jaszczyński), element prognozy makroekonomicznej publikowanej w każdym kwartale w: „Zeszytach Naukowych Instytutu Finansów” w latach 1990-1994.

Prywatyzacja w Polsce (współautorzy: M. Breitkopf, D. Jaszczyński), „Polityka ekonomiczna i społeczna” 1991, z. 6, Fundacja im. Fridricha Eberta w Polsce, Warszawa. 
Privatization in Poland (współautorzy: M. Breitkopf, D. Jaszczyński), „Polityka ekonomiczna i społeczna” 1991, z. 6, Fundacja im. Fridricha Eberta w Polsce, Warszawa.

The Polish Economy - 1992, The Forecast for 1993, (współautor: D. Jaszczyński), The Annual of the Economist Inteligence Unit, London 1993.

Prices, incomes and the consumer market, w: pracy zbiorowej pod redakcją naukowa G. Blazyca i R. Rapackiego pt. Poland into the 1990s. Economy and Society in Transition, Pinter Publishers London, London 1991.

Hyperinflation and Stabilization in Poland, w: pracy zbiorowej pod redakcją naukową A.K. Koźmińskiego i D.P. Cushman pt. Organizational Communication and Management. A Global Perspective, State University of New York Press, New York 1993.

The new banking and financial sector: its role, potential and weaknesses, w: pracy zbiorowej pod redakcją naukową G. Blazyca i R. Rapackiego pt. Poland into the New Millennium, Edward Elgar, Cheltenham UK, Northampton USA 2001.

Makroekonomiczne uwarunkowania i skutki polityki stabilizacyjnej w Polsce (współautor: D. Jaszczyński), w: pracy zbiorowej pod redakcją naukową G.W. Kołodko pt. Polityka finansowa, stabilizacja, transformacja, Instytut Finansów, Warszawa 2001.

Fundusze emerytalne na rynkach kapitatowych w Polsce latach 2000-2001 (wspótautor: A. Słupczyńnki), w: pracy zbiorowej pod redakcją naukową K. Rycia pt. Gospodarka $i$ przedsiębiorstwo. Nowe tendencje w zarządzaniu. Księga Jubileuszowa Wydziatu Zarzadzania UW, Wydawnictwo Naukowe Wydziału Zarządzana UW, Warszawa 2003.

Rynki finansowe, w: pracy zbiorowej pod redakcją naukową B. Kosińskiego i A.Z. Nowaka pt. Bank depozytowo-kredytowy, Wydawnictwo Naukowe Wydziału Zarządzania UW, Warszawa 2004.

Redakcja naukowa numeru Kwartalnika „Problemy Zarządzania” 2005, nr 2.

Architektura systemu pośrednictwa finansowego, „Problemy Zarządzania” 2005, nr 2.

Egzemplifikacja wybranych modeli makroekonomicznych w gospodarce polskiej w latach 1993-2005, w: pracy zbiorowej pod redakcją naukową A.Z. Nowaka pt. Fenomen transformacji. Próba analizy, Wydawnictwo Naukowe Wydziału Zarządzania UW, Warszawa 2005.

Architektura systemu finansowego gospodarki, Wydawnictwo Naukowe Wydziału Zarządzania UW, Warszawa 2005.

Makroekonomiczne skutki polityki fiskalnej i monetarnej w Polsce w latach 1993-2005 fakty, w: pracy zbiorowej pod redakcją naukową A. Sopoćko pt. Zrównoważony wzrost gospodarczy. Rola polityki finansowej. Polska droga do euro, Wydawnictwo Naukowe Wydziału Zarządzania UW, Warszawa 2006.

Architecture of financial agency system, w: pracy zbiorowej pod redakcją naukową A.Z. Nowaka, B. Glinki, P. Hensla pt. Management In Poland after accession 
to the EU. Selected aspects, Wydawnictwo Naukowe Wydziału Zarządzania UW,

Warszawa 2006.

Realne stopy zrerotu inwestorów krajowych i zagranicznych w Polsce w latach 1994-2005

(współautorzy: J. Górka, R. Winiarski), w: pracy zbiorowej pod redakcją naukową M. Duszy pt. Czynniki wzrostu gospodarczego w Polsce, Wydawnictwo

Naukowe Wydziału Zarządzania UW, Warszawa 2007.

Rynkowy system finansowy, PWE, Warszawa 2007.

Impact of Fiscal and Monetary Policy on the Economic Growth in Poland in the years 1993-2005, w: pracy zbiorowej pt. Reinventig Poland. Economic and political transformation and evolving national identity, Basees/Rouledge Serries on Russian and East European Studies, New York 2008.

Rynkowy system finansowy (wyd. II zmienione i uzupełnione, ss. 389), PWE, Warszawa 2009.

Fundusze parasolowe w Polsce - efektyrwność i ryzyko strategii inwestycyjnych, „Problemy Zarządzania” 2009, nr 1.

Materiaty do studiowania polityki pieniężnej, Wydawnictwo Naukowe Wydziału Zarządzania UW, Warszawa 2009.

Rynkowy system finansowy (wyd. III zmienione i uzupełnione, ss. 389), PWE, Warszawa 2009.

Wprowadzenie do finansówe, redakcja naukowa książki i współautorstwo (współautorzy: E. Kalwasińska, D. Maciejowska, J. Szczęsny, J. Śliwa, M. Winter), Wydawnictwo Naukowe Wydziału Zarządzania UW, Warszawa 2010.

Wyniki testórw hipotezy pótsilnej efektyrwności informacyjnej Gietdy Papierórw Wartościowych w Warszawie w latach 2005-2011 (współautor: D. Bulski), „Problemy Zarządzania” 2012, nr 4.

Makroekonomiczne skutki polityki fiskalnej i monetarnej w Polsce w latach 1993-2015, w: pracy zbiorowej pt. Gospodarka na rozdrożu XXI wiek, pod redakcją naukową A.Z. Nowaka, Wydawnictwo Naukowe Wydziału Zarządzania UW, Warszawa 2015.

Makroekonomiczne uwarunkowania Nowej Polityki Strukturalnej-przypadek Polski, w: pracy zbiorowej pt. Nowa Ekonomia Strukturalna wobec krajów mniej zaawansowanych (New Stuctural Economis for less advenced contries) pod redakcją naukową J. Yifu Lina’a i A.Z. Nowaka, Wydawnictwo Naukowe Wydziału Zarządzania UW, Warszawa 2017.

Rynkowy system finansowy (wyd. IV zmienione i uzupełnione, ss. 400), PWE, Warszawa 2018.

\section{Ważniejsze niepublikowane raporty i ekspertyzy}

Ocena skutków regulacji dla Ustawey o ustanowieniu „Programu finansowego wesparcia nowych inwestycji wieloletnich o dużym znaczeniu dla gospodarki”, ekspertyza wykonana na zlecenie Ministerstwa Gospodarki, Warszawa 2003. 
Ocena projektu Ustawy o finansowym wspieraniu inwestycji, na zlecenie Biura Studiów i Ekspertyz Kancelarii Sejmu RP, Warszawa 2001.

Finansowe aspekty dziatalności Agencji Techniki $i$ Technologii, ekspertyza wykonana na zlecenie Ministerstwa Gospodarki, Warszawa 2000.

Skutki budżetowe Ustawy o finansowym wspieraniu inwestycji, ekspertyza wykonana na zlecenie Ministerstwa Gospodarki, dołączona jako załącznik do Ustawy, Warszawa 2000.

Czy sa potrzebne fundusze kapitatowe Skarbu Państwa? Jeżeli tak, to jakie?, ekspertyza wykonana na zlecenie Rady Społeczno-Gospodarczej przy Radzie Ministrów, Warszawa 1996.

Raport o realizacji programów resortowych w przemyśle lekkim oraz stopniu przygotowania tych przemystów do integracji z Unia Europejska, ekspertyza wykonana na zlecenie Ministra Przemysłu i Handlu, Warszawa 1996.

AVIS - koordynacja w procesie wypetniana przez Rzad RP kwestionariusza przed akcesyjnego do Unii Europejskiej. Materiały obejmujące 2700 stron oceniające stopień spełniania przez Polskę wymogów i warunków członkostwa, tj. zdolności do przyjęcia i stosowania regulacji wspólnotowych oraz stabilność i wyniki gospodarcze. Dokument przesłany przez Rząd do Komisji Europejskiej w lipcu 1996 roku. Projekt zrealizowany w Premium-econ na zlecenie Ministra Przemysłu i Handlu.

Ocena spoteczno-ekonomicznych skutków utworzenia Specjalnej Strefy Ekonomicznej w województwie watbrzyskim, ekspertyza wykonana na zlecenie Ministra Przemysłu i Handlu, Warszawa 1996.

Organizacja i finansowanie Agencji Techniki $i$ Technologii, ekspertyza i przygotowanie projektu ustawy sejmowej powołującej Agencję, na zlecenie Ministra Przemysłu i Handlu, Warszawa 1996.

Wycena i prywatyzacja spótki „POLMO - PRASZKA” S.A., projekt zrealizowany w Premium-econ na zlecenie Ministra Przekształceń Własnościowych, Warszawa 1996.

Kwartalne krótko-, średnio- $i$ dtugoterminowe prognozy makroekonomiczne (tempo wzrostu, inflacja, bezrobocie, kursy walutowe itp.), projekt realizowany wraz z J. Rajskim w Premium-econ w latach 1995-1998 na zlecenie FIAT AutoPoland S.A. oraz POLMOT Holding S.A.

Spoteczno ekonomiczne skutki utworzenia Specjalnej Strefy Ekonomicznej w Mielcu, projekt zrealizowany w Premium-econ w kooperacji z irlandzką firmą konsultingową „Shannon Development”, na zlecenie Ministerstwa Przemysłu i Handlu, Warszawa 1995.

Prywatyzacja spótki „CORA Garwolin” S.A. projekt zrealizowany wraz z D. Jaszczyńskim i M. Breitkopfem w Premium-econ, Warszawa 1995.

Program restrukturyzacji finansowej Zaktadów Tkanin Dekoracyjnych „DEKORA” S.A. w ramach Ugody Bankowej z Bankiem Zachodnim S.A., projekt zrealizowany w Premium-econ, Warszawa 1994. 
The shadow economy in Poland in the period of systemic transformation, raport wykonany na zlecenie European Assotiation of Comparative Economic Studies, Warszawa 1994.

Restrukturyzacja finansowa przedsiębiorstwe i bankówe, materiały szkoleniowe przygotowane na zlecenie Fundacji Centrum Prywatyzacji dla pracowników Ministerstwa Finansów i wybranych banków, Warszawa 1993.

Makroekonomiczne skutki programu masowej komercjalizacji przedsiębiorstw państwowych, ekspertyza wykonana wraz z D. Jaszczyńskim i M. Breitkopfem na zlecenie Ministra Przekształceń Własnościowych, Warszawa 1992. 


\section{Wykaz wypromowanych doktoratów}

1. Alojzy Z. NowAK, tytuł rozprawy doktorskiej: Druga gospodarka a polityka pieniężna w Polsce w latach 80-tych, tytuł doktora nadany przez Wydział Zarządzania, Uniwersytet Warszawski (stopień nadany w 1991 r.).

2. Tesfaye Alamu, tytul rozprawy doktorskiej: The Role of Central Bank In the Process of Formulating Monetary Policy, tytuł doktora nadany przez Wydział Zarządzania, Uniwersytet Warszawski (stopień nadany w 1998 r.).

3. Tomasz GRZELAK, tytuł rozprawy doktorskiej: Rozwój kapitatu wysokiego ryzyka w Polsce na tle dośrwiadczeń europejskich, tytuł doktora nadany przez Wydział Zarządzania, Uniwersytet Warszawski (stopień nadany w 2005 r.).

4. Arkadiusz ANTOsIK, tytuł rozprawy doktorskiej: Efektywność subsydiowania kredytów eksportowych, tytuł doktora nadany przez Wydział Zarządzania, Uniwersytet Warszawski (stopień nadany w 2006 r.).

5. Radosław WINIARSKI, tytuł rozprawy doktorskiej: Kreowanie wartości dodanej w Otwartych Funduszach Emerytalnych, tytuł doktora nadany przez Wydział Zarządzania, Uniwersytet Warszawski (stopień nadany w 2007 r.).

6. Małgorzata OLSZAK, tytuł rozprawy doktorskiej: Wptyw norm adekwatności kapitatowej na zarzadzanie portfelem kredytowym banków w Polsce, tytuł doktora nadany przez Wydział Zarządzania, Uniwersytet Warszawski (stopień nadany w 2007 r.).

7. Marcin Kobus, tytuł rozprawy doktorskiej: Produkty strukturyzowane na rynku finansowym w Polsce, tytuł doktora nadany przez Wydział Zarządzania, Uniwersytet Warszawski (stopień nadany w 2008 r.).

8. Jakub GÓRKA, tytuł rozprawy doktorskiej: Konkurencyjność form pieniądza $i$ instrumentów płatniczych, tytuł doktora nadany przez Wydział Zarządzania, Uniwersytet Warszawski (stopień nadany w 2008 r.).

9. Monika KAŁUŻA-WIŚNIEWSKA, tytuł rozprawy doktorskiej: Perspektyroy rozwoju międzybankowych systemów platności w europejskim systemie bankowym, tytuł doktora nadany przez Wydział Zarządzania, Uniwersytet Warszawski (stopień nadany w 2009 r.).

10. Patrycja ChODNICKA, tytuł rozprawy doktorskiej: Przeciwedziatanie praniu pieniędzy w sektorze bankowym, tytuł doktora nadany przez Wydział Zarządzania, Uniwersytet Warszawski (stopień nadany w 2013 r.). 
11. Piotr JAWORSKI, tytuł rozprawy doktorskiej: Efektywonośc $i$ ryzyko polskich funduszy Absolutnej Stopy Zwrotu, tytuł doktora nadany przez Wydział Zarządzania, Uniwersytet Warszawski (stopień nadany w 2015 r.).

12. Marcin IGNATOWSKI, tytuł rozprawy doktorskiej: Wykorzystanie wewnętrznych cen transferowych w zrządzaniu plynnościa w banku, przewód otwarto na Wydziale Zarządzania, Uniwersytet Warszawski (przewód otwarty w 2016 r.). 


\section{SYSTEM FINANSOWY - ANALIZY I ROZWAŻANIA}



KRZYSZTOF JAJUGA*

\section{Financial Investments - Systematization}

The paper presents an attempt to systematize different classes of financial investments. The basic criterion is to distinguish between direct and indirect investments. The other criterion is risk exposure, which allows for distinguishing five general classes of investment assets. The paper offers a short review of each class. Then a general framework to systematize financial assets is proposed.

Keywords: financial investment, real asset, environmental asset, financial instrument, digital asset.

\section{INWESTYCJE FINANSOWE - SYSTEMATYZACJA}

Rozdziat przedstawia próbę systematyzacji różnych klas inwestycji finansowych. Podstawowe kryterium wyróżnia inwestycje bezpośrednie i pośrednie. Innym kryterium jest ekspozycja na ryzyko, co pozwala na wyróżnienie pięciu klas aktywów inwestycyjnych. W rozdziale przedstawiono przeglad tych klas. Następnie zaproponowano ogólny schemat systematyzacji aktyrwów finansowych.

Słowa kluczowe: inwestycja finansowa, aktywa realne, aktywa środowiskowe, instrument finansowy, aktywa cyfrowe.

JEL: G11, G15

"Prof. dr hab. Krzysztof Jajuga - Wrocław University of Economics [Uniwersytet Ekonomiczny we Wrocławiu]. 


\section{Introduction}

The last two decades have been characterized by the very dynamic development of financial markets. This has resulted in the growth in the number of assets being the object of financial investments. It is estimated that at the end of 2017, the value of the world debt market was about USD 215 trillion and the value of the world equity market was about USD 73 trillion. It could be compared to the world nominal GDP equal to about USD 80 trillion. In addition, there are - other than debt and equity - investment markets, for example a very fast growing derivative market, which has the market value of USD 13 trillion, however its notional value is USD 542 trillion.

The paper presents an attempt to systematize different assets being the object of financial investments. Since the number of assets is very large, the systematization of them is not an easy task; hopefully the paper can contribute to the scientific discussion about systematization of financial investments.

We take a very practical approach and decide to consider two general classifications of assets which occur in financial investments.

The first general classification contains two types of investments:

- Direct investments;

- Indirect investments.

Fig. 1. Direct investment and indirect investment.

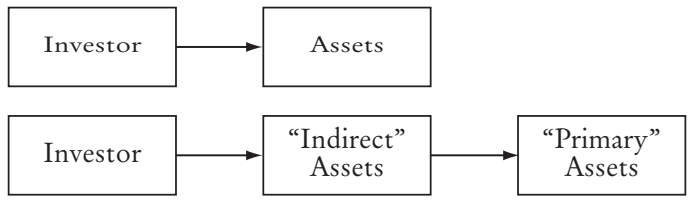

Indirect investments are here understood as investments in some assets ("indirect" assets) the value of which depends on other assets ("original", "primary" assets). The difference between direct and indirect investments is presented in Figure 1. Here the upper part presents direct investment and the lower part presents indirect investment.

The analysis of possible indirect investments leads us to the conclusion that there are four classes of assets to be considered as "indirect" assets:

- shares in collective investment institutions (like mutual funds);

- selected debt instruments;

- selected equity instruments;

- derivative instruments. 
There are two different cases in indirect investments.

The first case is the situation in which assets being the object of indirect financial investment are managed by some entity and this entity invests directly in the market. Out of the mentioned four classes, three classes follow this pattern: selected debt instruments, selected equity instruments and shares in collective investment institutions.

The second case is the situation in which assets in indirect investment are defined through some kind of index which depends on the prices of assets typical for direct investments. This is the case when the object of indirect investment is a derivative instrument.

In fact, it can happen that in some indirect investment "primary" assets can be other indirect assets. It is so, for example, when one invests in a mutual fund (being a collective investment institution), and this fund invests in derivative instruments (being indirect assets).

The second general classification of investments is based on the type of risk to which investment is exposed. There are five general classes of assets:

- real assets;

- environmental assets;

- components of business projects (tangible and intangible assets);

- financial assets;

- digital assets.

This is not a disjoint classification. In particular, environmental assets and components of business projects are at the same time financial assets. However, they are very specific assets, so we decided to put them into different groups. The same problem refers to real assets - they can be components of business projects.

The remaining part of the paper offers a review of different classes of assets with the indication of their use in direct and indirect investments.

\section{Classes of Assets - Real Assets}

Real assets exist in the physical form, they are the effect of human activity. They contain the following classes:

1. Commodities.

2. Real estate.

3. Emotional assets. 
These assets can be the object of direct investments and the object of indirect investments (as "primary" assets).

\section{Commodities}

Direct investment in commodities is made if commodities occur in a physical form. However, despite such a possibility, this is not a common case. Commodities in the physical form are usually used either in consumption or in the production process. Investing in commodities occurring in a physical form is not common, since it requires additional costs of storage and insurance.

There are three general classes of commodities traded on the markets:

1. Agricultural and soft commodities, this class contains:

- agricultural commodities,

- soft commodities.

2. Metals, this class contains:

- precious metals,

- industrial metals.

3. Energy, this class contains:

- energy resources,

- electrical energy.

Table 1 presents the most important commodities traded on the world markets.

Tab. 1. Main commodities.

\begin{tabular}{|l|l|}
\hline \multicolumn{1}{|c|}{ Class of commodities } & \multicolumn{1}{c|}{ Commodity } \\
\hline Agricultural commodities & wheat, rice, soybean, corn \\
\hline Soft commodities & sugar, coffee, cocoa, orange juice, meat \\
\hline Precious metals & gold, silver, platinum, palladium \\
\hline Industrial metals & copper, tin, zinc, lead, nickel, aluminum \\
\hline Energy resources & crude oil, natural gas, coal \\
\hline Electrical energy & electricity \\
\hline
\end{tabular}

It is worth mentioning that electrical energy also contains energy which comes from renewable sources: solar energy, wind energy, geothermal energy, etc. 
Since commodities in the physical form are mostly used either for consumption or for the production process, investment in commodities is usually made through indirect investments, mostly in three forms:

- Shares in collective investment companies, e.g. mutual funds;

- Equities of enterprises involved in the production of commodities;

- Derivatives based on the underlying index being the commodity price.

A detailed presentation of commodity investments is given by Geman (2005), Schofield (2007) and Sierakowska (2016).

\section{Real Estate}

This is a very large class of investments. When considered as direct investment, real estate investments contain three classes of investments:

- Residential real estate;

- Commercial real estate, including mainly: office real estate, retail real estate, industrial real estate (e.g. logistic centers, warehouses), hotels and convention centers, special real estate objects (e.g. amusement parks, golf courses, gasoline stations, historical monuments);

- Land (including farmland and timberland).

The main features of direct investments in real estate are: lack of liquidity, large lot sizes, relatively high transaction costs, heterogeneity, immobility, low information transparency. This leads to the following advantages and disadvantages of this type of investments:

- Advantages: possibility of high leverage due to mortgage loans, control over property, geographical diversification, relatively low volatility.

- Disadvantages: lack of divisibility, high information costs, high commissions, substantial operating costs, risk of neighborhood deterioration.

Indirect investments form a substantial part of real estate investments. They can be made in the following forms:

- shares in collective investment companies, e.g. equity real estate investment funds and debt real estate investment funds;

- equities of companies engaged in real estate ownership, for example: home builders and real estate operating companies, as well as investments in public infrastructure projects; 
- debt instruments, including mortgage backed home loans and mortgage backed securities (like covered bonds);

- derivatives based on the underlying index being the real estate market index (real estate derivatives, property linked derivatives).

Real estate indices can be based on three pieces of information:

- prices of properties (obtained from transactions);

- value of properties (obtained from professional appraisers);

- income from properties (obtained from indirect investments).

It is worth mentioning that real estate derivatives, except being investment vehicles (providing exposure to the real estate market without physical investment in property), can also be used as risk management tools.

A detailed presentation of real estate investment is given by Haight and Singer (2005) and Syz (2008).

\section{Emotional Assets}

This is a very specific class of assets, with a rather small contribution in investment markets.

The most important classes of emotional assets are:

- art (mainly paintings);

- stamps;

- coins;

- diamonds;

- wine;

- whisky;

- antique cars;

- musical instruments (mainly violins);

- jewelry;

- clocks and watches;

- photographs;

- atlases;

- books;

- antiques.

It is worth mentioning that the class of emotional assets contains very heterogeneous assets, for example typical collectible assets (like stamps, photographs or antiques) or connoisseur assets (like art, wine or whisky). 
If emotional assets are considered as direct investments, we have to point out that the key role is played by the goal of the purchase of a particular asset. In most cases, these assets are purchased by a collector (like in the case of art or stamps), which should not be considered as investment but rather as some kind of consumption. If, however, one purchases an emotional asset and expects an increase in price in order to sell it at a higher price, this is clearly investment.

A detailed presentation of emotional investments is given by Dimson and Spaenjers (2014).

\section{Classes of Assets - Environmental Assets}

This is a relatively new class of assets. The role of these assets has grown in the $21^{\text {st }}$ century due to the importance of the natural environment and climate. They are related to the acts of nature and the influence of humans on the nature.

Environmental assets can be found only in indirect investments, in all possible forms of indirect investments. As a rule, these assets are in the form of financial instruments.

There are four classes of environmental assets:

- assets related to water;

- assets related to air;

- assets related to climate;

- assets related to natural catastrophes.

The first two classes are related to the main values that nature gives to humans. The last two classes are related to the changes in the natural environment.

Investment in assets related to water is made either by investing in equities of companies which are parts of the value chain of the water market (e.g. distribution of water) or by investing in indices revealing the same performance as that of the water market.

Investing in assets related to air is made through investing in some kind of derivative instruments being emission rights. The most important emissions are: sulfur dioxide, nitrogen oxide and carbon dioxide.

Investment in assets related to climate is mostly made through investing in several types of indices reflecting: temperature, rainfall, snowfall and 
wind speed. For the investor, this creates an exposure to weather changes. This investor accepts the weather risk taken over from another party that uses weather derivatives.

Investment in assets related to natural catastrophes is mostly made through investing in several types of indices reflecting losses resulting from such catastrophes as: earthquake, flood, hurricane, tsunami, volcanic dust. For the investor, this creates an exposure to the occurrence of natural catastrophes. This investor accepts the catastrophe risk taken over from another party, such as an insurance company, which uses catastrophe derivatives to limit losses.

A detailed presentation of environmental assets is given by Sandor, Clark, Kanakasabai and Marques (2014).

\section{Classes of Assets - Components of Business Projects}

It is now very often the case that one invests in business projects carried out by companies. Then these projects are usually separated from the usual business of the company and conducted within some kind of framework (usually the so-called project finance). There are two general types of assets being components of business projects:

- Tangible assets;

- Intangible assets.

\section{Tangible Assets in Business Projects}

Business projects are realized by companies under the common name "investment projects". Tangible assets such as factories, technological lines, machines, etc. are the main components of these projects. Buildings can also be such components. In this case, they are not considered as real estate, since they are an inherent part of business projects rather than separate properties.

\section{Intangible Assets in Business Projects}

Business projects can also contain intangible assets such as:

- the brand of the company;

- intellectual properties (including patents, trademarks, utility designs);

- copyrights;

- know-how about a particular company;

- other intangible assets (e.g. customer databases). 
Both classes of assets can occur either as direct investment assets or as primary assets in indirect investments. However, they are not separate investments but only inherent parts of the business project that is invested in. Due to their specific character, there are no indices that can perform similarly to the indices of these classes of assets.

\section{Classes of Assets - Financial Assets}

This is the most common class of financial investments, therefore it does not require a very detailed presentation. There are five general classes of financial assets:

- debt financial instruments (including money market instruments and bonds);

- equity financial instruments (including stocks);

- shares in collective investment institutions;

- derivative instruments;

- currencies.

One can also distinguish hybrid financial instruments being a combination of (at least) two classes of assets mentioned above. The best example is probably a combination of debt and derivative instruments. Such a type of hybrid instrument is a structured product which is a bond with an embedded option.

One of the classes of financial assets contains shares in collective investment institutions. This is a rather heterogeneous class which contains:

- open end mutual funds (active and passive funds);

- closed end mutual funds (investment certificates);

- hedge funds;

- private equity funds;

- Exchange Traded Funds (ETF).

Each of these instruments is offered by financial institutions. The first four classes are typical shares in financial institutions. The value of a share is determined by the value of the portfolio of assets managed by these institutions. The main differences between them can be stated as follows:

- private equity funds are highly involved in active management of the companies composing their investment portfolio (which is not necessarily the case of the other classes); 
- hedge funds are loosely regulated investment institutions with very broad groups of assets in their investment portfolios, the key point in their potentially good investment performance is the application of an advanced investment strategy;

- some open end mutual funds are passively managed by a tracking benchmark being a market index;

- closed end mutual funds are specialized in investing in a specific type of (primary) assets, like real assets.

The remaining class, Exchange Trade Index, is a financial asset which tracks the performance of the market index. This class has become very popular in the $21^{\text {st }}$ century. ETFs are offered and managed by financial institutions, similarly to passively managed investment funds; however, they have much lower management fees and their performance is strictly evaluated by the tracking error.

\section{Classes of Assets - Digital Assets}

The name "digital asset" has two meanings. The wider sense means all assets that can be stored in a digital form (for example photographs). The narrower sense means a relatively new class of assets which has become very popular in the last few years. They are generated with the use of digital (computer) technology. This technology is rather advanced. At the current stage, most digital assets are generated by the blockchain technology. The attractiveness of blockchain technology results from the fact that:

- it can be considered as a distributed ledger (or spreadsheet);

- this is (as the name says) a chain of blocks of data;

- there is very fast access to data;

- input data cannot be changed, which makes the spreadsheet very transparent;

- it allows for determining the owner of the asset at any time in the past;

- data in a block are encrypted with a very powerful encrypting tool.

Digital assets do not have a physical form. In addition, they (as a rule) do not fall into the traditional concept of financial instruments.

The main digital assets are the so-called cryptocurrencies. This name is somehow misleading, because these assets have nothing to do with curren- 
cies. The first cryptocurrency was the bitcoin, which was meant to be used as a means of payment and this role has been played effectively. However, not much time ago (less than two years ago) considerable excitement about investing in bitcoins started. This resulted in the creation of at least several thousand cryptocurrencies. Many of them are fake investment assets, most of them are harmful investment vehicles. The main problem of cryptocurrencies is that they are not transparent, not understood by investors and driven mostly by emotions.

\section{Common Framework to Systematize Assets}

The two presented classifications containing numerous classes of assets are linked and have common features. Their common elements are worth mentioning such as:

- in indirect investments, indirect assets contain all financial assets, except currencies;

- among financial assets, two groups are not primary assets of indirect investments, namely: shares in collective investment institutions and derivative instruments;

- environmental assets occur only in indirect investments (as primary assets);

- the following classes can be assets in both indirect (as primary assets) and direct investments: real assets, business projects, debt and equity financial assets and digital assets.

This is summarized in Table 2.

It is worth noticing that another important difference between direct and indirect investments lies in the risk exposure of both investments, namely:

- In indirect investments, there is exposure to risk of indirect assets, which contains the risk of primary assets and the risk of indirect assets;

- In direct investments, there is exposure to risk of direct assets.

As an example, let us take investment in real estate. Here:

- Direct investment means exposure to real estate price risk;

- Indirect investment - for example in mutual fund investing in real estate - means exposure to real estate price risk and exposure to the risk of mutual fund market. 
Tab. 2. Different classes of assets in different types of investments.

\begin{tabular}{|l|c|c|c|}
\hline \multicolumn{1}{|c|}{ Class of assets } & $\begin{array}{c}\text { Assets in direct } \\
\text { investments }\end{array}$ & $\begin{array}{c}\text { Indirect assets in } \\
\text { indirect investments }\end{array}$ & $\begin{array}{c}\text { Primary assets in } \\
\text { indirect investments }\end{array}$ \\
\hline Commodities & YES & NO & YES \\
\hline Real estate & YES & NO & YES \\
\hline Emotional assets & YES & NO & YES \\
\hline Environmental assets & NO & NO & YES \\
\hline Assets in business projects & YES & NO & YES \\
\hline Debt financial instruments & YES & YES & YES \\
\hline Equity financial instruments & YES & YES & YES \\
\hline Derivative instruments & NO & YES & NO \\
\hline $\begin{array}{l}\text { Shares in collective } \\
\text { investment institutions }\end{array}$ & NO & YES & YES \\
\hline Currencies & YES & NO & YES \\
\hline Digital assets & YES & NO & \\
\hline
\end{tabular}

Let us note that in the theory and practice of investments, the term "alternative investments" has been used for quite a long time. Alternative investment is understood as any type of investment in which assets are different from two most popular assets: debt financial instruments and equity financial instruments traded on the public market. The main differences between "classical" investments and alternative investments are as follows:

- lower liquidity of alternative investments, which leads to a liquidity premium and a higher return on alternative investments;

- many opportunities to reduce the risk of the portfolio;

- high due diligence costs;

- some problems of the benchmark to evaluate investment performance.

Practitioners identify four main classes of alternative investments: commodities, real estate, equity financial instruments traded on the non-public market and shares in some collective investment institutions (mostly hedge funds). 


\section{References}

Dimson, E. \& Spaenjers, C. (2014). Investing in emotional assets. Financial Analyst Journal, $70(2), 20-25$.

Geman, H. (2005). Commodities and commodity derivatives: Modeling and pricing for agriculturals, metals and energy. New York: Wiley.

Haight, G.T. \& Singer, D.D. (2005). The real estate investment handbook. New York: Wiley.

Sandor, R.L., Clark, N.J., Kanakasabai, M., \& Marques, R.L. (2014). Environmental markets: A nerw asset class. Charlottesville: CFA Institute Research Foundation.

Schofield, N.C. (2007). Commodity derivatives: Markets and applications. New York: Wiley.

Sierakowska, D. (2016). Świat surowcówe. Warszawa: Trend Edukacja Finansowa.

Syz, J.M. (2008). Property derivatives: Pricing, hedging and applications. New York: Wiley. 



\section{LESZEK PAWEOWICZ"}

\section{Moral hazard w pośrednictwie finansowym}

Rozpowszechnienie moral hazard w pośrednictwie finansowym stanowito gtówna przyczyne kryzysu finansowego w 2009 roku. Moral hazard nadal funkcjonuje w otoczeniu instytucjonalnym obfitujacym w konflikty interesów i nie wydaje się prawdopodobne, aby nowe regulacje mające na celu wwiarygodnienie banków i zwiększenie stabilności systemu finansowego (TLAC, MREL, BRR i in.) ograniczyty moral hazard do bezpiecznych rozmiarów. System motywacji w pośrednictwie finansowym równiez nie ulegt istotnym zmianom, a populizm polityczny istotnie zwiększa ryzyko systemowe. Nowe otoczenie instytucjonalno-regulacyjne nie przywrócito zaufania na rynkach finansowych $i$ nie gwarantuje zrównoważonego rozwoju spoteczno-gospodarczego.

Słowa kluczowe: Moral hazard, podział ryzyka, asymetria informacji, kryzys bankowy, ryzyko finansowe.

\section{MORAL HAZARD IN FINANCIAL INTERMEDIATION}

The spread of moral hazard in financial intermediation was the main cause of the financial crisis in 2009. Moral hazard continues in the institutional environment, which is full of conflicts of interest, and it seems unlikely that new regulations aimed at making banks more credible and at increasing the stability of the financial system (i.a. TLAC, MREL, $B R R$ ) have reduced moral hazard to a safe level. The system of motivation in financial intermediation bas not changed significantly, and political populism seriously increases systemic risk. The new institutional and regulatory environment bas not restored confidence on financial markets and does not guarantee sustainable social and economic development.

Keywords: moral hazard, risk sharing, asymmetric information, bank crisis, financial risk.

JEL: D81, D82, G21, G32

* Dr hab. Leszek Pawłowicz, prof. nadzw. - Wydział Zarządzania Uniwersytetu Gdańskiego. Orcid ID: 0000-0003-2580-6708. 


\section{Pojęcie moral hazard}

W końcu XIX wieku pojęcie moral hazard używane było przez angielskie instytucje ubezpieczeniowe $\mathrm{w}$ znaczeniu wyłącznie negatywnym, implikującym defraudacje i niemoralne zachowanie (Dembe i Boden, 2000). Później uległo ono modyfikacji. Paul Krugman rozumie moral hazard jako „każdą sytuację, w której osoba podejmuje decyzję o tym ile może podjąć ryzyka, a kto inny ponosi koszty, jeśli sprawy pójdą źle" (any situation in with one person makes the decision about how much risk to take, while someone else bears the cost if things go badly) (Krugman, 2009). Jest to zatem sytuacja, w której decydent ma tendencje do podejmowania nadmiernego ryzyka, ponieważ koszty z tym związane go nie obciążają.

Cechą charakterystyczną moral hazard jest ponadto, że nie jest to sytuacja o charakterze jednorazowym, lecz są to trwale występujące uwarunkowania (Situation where a party will have a tendency to take risks...) (wikipedia.org, 2018).

Generalnie przez moral hazard będziemy rozumieli nie tylko jednorazową pokusę nadużycia, lecz także powtarzające się sytuacje, w których podejmowane są decyzje obarczone ryzykiem bez konsekwencji dla podejmujących te decyzje. Stymuluje to działania mniej ostrożne, ponieważ ryzyko ponosi któs inny i kreuje ryzyko o charakterze systemowym.

Nie kwestionując zatem poprawności tłumaczenia tego pojęcia na język polski jako hazardu moralnego lub pokusy nadużycia, w niniejszym rozdziale będzie ono wykorzystywane w oryginalnej, angielskiej formie.

\section{Czy moral hazard jest niemoralny?}

Moral hazard może mieć różne nasilenie, zależne od skali odpowiedzialności decydenta za skutki swoich decyzji. Jeśli podejmujący decyzje odpowiada za ich negatywne skutki w całości, wówczas należy przyjąć, że moral hazard nie ma miejsca, jeśli zaś odpowiedzialności w całości unika, wówczas moral hazard można uprawiać bezkarnie. Inaczej mówiąc, bezkarność w zakresie odpowiedzialności za podejmowane decyzje oznacza maksymalną pokusę nadużycia, a pełna odpowiedzialność za podjęte decyzje - brak tej pokusy.

W praktyce gospodarczej skala odpowiedzialności za podejmowane decyzje jest zróżnicowana. I tak np. w spółkach kapitałowych miarą odpowiedzialności może być poziom kapitału własnego w stosunku do zaciąganych zobowiązań, czyli dźwignia finansowa. Ogólnie ujmując, im większa dźwignia 
finansowa, tym pokusa nadużycia jest większa, przy założeniu, że decyzje podejmowane są przez właścicieli kapitału własnego spółki.

W większości spółek kapitałowych właściciele (akcjonariusze) nie pełnią jednak funkcji zarządczych, a systemy motywacji dla zarządców mogą w różnym stopniu uwzględniać konsekwencje podejmowanych przez nich decyzji. Dlatego w kodeksach dobrych praktyk dla menedżerów spółek kapitałowych zaleca się wynagradzanie instrumentami kapitałowymi oraz odraczanie wypłat bonusów i przekazywanie ich do banku premii (systemy bonus malus) (Pawłowicz, 2015). Wynagradzanie instrumentami kapitałowymi (głównie akcjami i opcjami na akcje) wykorzystywane jest w celu zniwelowania konfliktów celów i pragnien pomiędzy agentem (menedżerem) i właścicielem, szeroko opisywanych $\mathrm{w}$ teorii agencji. Banki premii założono natomiast, aby w przypadku zniszczenia wartości spółki przez nieodpowiedzialne decyzje menedżerów, nie uniknęli oni konsekwencji tych decyzji. Ryzyko utraty wypracowanych wcześniej bonusów ma ograniczyć bezkarność decydentów, a tym samym zniwelować moral hazard.

Generalnie należy przyjąć, że moral hazard narasta, gdy ludzie i instytucje nie ponoszą konsekwencji swoich działań, stymuluje wówczas do działań mniej ostrożnych, w świetle etyki jest często zachowaniem niemoralnym, w świetle ekonomii może zaś zakłócić efektywne działanie rynku.

Pojęcie moral hazard ma wymiar negatywny jedynie wówczas, gdy koszty ryzyka obciążają strony trzecie bez ich zgody. Transfer ryzyka, który odbywa się za zgodą stron nie ma negatywnych znamion moral hazard. Sytuacje takie są powszechne na rynku ubezpieczeniowym, rynku kapitałowym, a szczególnie na rynku opcji. Linią podziału między transferem ryzyka a niemoralnym moral hazard jest klasyczna paremia prawnicza volenti non fit iniuria (łac. chcacemu nie dzieje się krzywda) sformułowana przez Ulpiana Domicjusza (wikipedia.org, 2018a). Inaczej mówiąc, jeśli strony transakcji godzą się na jej ewentualne kosztowe konsekwencje i są świadome ponoszonego ryzyka, trudno mówić o niemoralnym moral hazard.

Kwestia moralności moral hazard jest przedmiotem zainteresowania naukowców zajmujących się etyką w biznesie i zależy od światopoglądu oceniającego (szerzej: Klepczarek, 2015). Często błędnie utożsamiany jest $\mathrm{z}$ intencją oszustwa. Niezależnie jednak od etycznej oceny, moral hazard sprzyja lekkomyślności i beztrosce w podejmowaniu decyzji biznesowych, tworzy bowiem często środowisko, w którym korzyści stają się prywatne a straty publiczne.

Dobitniej wyraża to profesor Marek Belka: „Pojawiają się bodźce, by nie penalizować nadmiernego ryzyka, ale wręcz je podejmować. Wszyscy 
zaangażowani - wierzyciele, udziałowcy, pracownicy - wygrywają. Pozostali, czyli większość, w tym przysłowiowy podatnik, pokrywają jedynie straty. W rezultacie mamy kapitalizm zysków i socjalizm strat” (Belka, 2015). Nie ulega wątpliwości, że moral hazard powoduje zakłócenia i nieprawidłowości $\mathrm{w}$ funkcjonowaniu rynku, a w konsekwencji może prowadzić do nie tylko kryzysu finansowego, lecz także uzasadnionych niepokojów i konfliktów społecznych.

Niemoralny moral hazard na rynkach finansowych towarzyszy niestety globalizacji, umożliwia m.in. transgraniczny transfer ryzyka. Poprzez tzw. efekt zarażenia (contagion effect) może powodować sytuacje, kiedy kryzys w jednym kraju może wywołać zaburzenia w innym kraju, a w rezultacie może stymulować działania antyglobalistów, ale również prowadzić do napięć w stosunkach międzynarodowych, a nawet wojen. Internacjonalizacji kosztów towarzyszy bowiem ryzyko nacjonalizacji strat.

\section{Moral hazard a ryzyko systemowe}

We współczesnym świecie moral hazard jest ściśle związany z systemami motywacji m.in. dla zarządzających spółkami kapitałowymi. Obejmuje również agentów i brokerów, doradców finansowych, agencje ratingowe, firmy audytorskie, a także polityków zdobywających władze populistycznymi hasłami i kreuje uzasadnione frustracje i ryzyko kryzysów społeczno-gospodarczych. Moral hazard może być ograniczony do rozmiarów gwarantujących zrównoważony rozwój gospodarczy, może jednak także prowadzić do niszczenia wartości firm i krajów, a także katastrof społeczno-gospodarczych.

Szczególnie niebezpieczny jest moral hazard wynikający z błędnych rozwiązań systemowych, ponieważ jego nasilenie może powodować destrukcję na niespotykaną skalę $\mathrm{w}$ związku $\mathrm{z}$ postępującymi procesami globalizacji życia społeczno-gospodarczego.

Współczesny sektor pośrednictwa finansowego obfituje w błędne rozwiązania systemowe stymulujące moral hazard. W opinii wielu ekonomistów moral hazard $\mathrm{w}$ pośrednictwie finansowym uważany jest za najważniejszą przyczynę kryzysu finansowego w 2008 roku.

W literaturze przedmiotu trudno znaleźć jednoznaczną definicję pośrednika finansowego. Najczęściej uważa się, że klasycznym pośrednikiem finansowym jest bank, który pożycza fundusze od oszczędzających, a następnie udostępnia je kredytobiorcom. Burzliwy rozwój sektora finansowego od połowy lat dziewięćdziesiątych spowodował, że pojęcie pośrednictwa finan- 
sowego uległo istotnemu rozszerzeniu i obejmuje szereg instytucji pozabankowych funkcjonujących samodzielnie lub w kooperacji z bankami na podstawie umów outsourcingowych, umów agencji i innych określających zasady współpracy, odpowiedzialności, kontroli i zarządzania ryzykiem (por. Barembruch, 2007).

Szersza definicja pośrednika finansowego zawarta jest w rozporządzeniu Komisji Europejskiej (UE) nr 651/2014 z dnia 17 czerwca 2014 r. Komisja Europejska definiuje pośrednika finansowego jako każdą instytucję finansową, bez względu na jej formę i strukturę własności, świadczącą usługi na rzecz podmiotów dysponujących oszczędnościami (podmioty nadwyżkowe) oraz podmiotów poszukujących funduszy pieniężnych (podmioty deficytowe) w celu sfinansowania ich zamierzeń konsumpcyjnych, inwestycyjnych i produkcyjnych.

W pośrednictwie finansowym klasycznym przykładem moral hazard połączonego z błędnymi rozwiązaniami systemowymi jest tańcuch moral hazard towarzyszący procesowi sekurytuzacji kredytów. Sprzężony jest on z permanentnym konfliktem interesu instytucji i osób zaangażowanych $\mathrm{w}$ ten proces (rys. 1).

\section{Rysunek 1. Łańcuch moral hazard w procesie sekurytyzacji kredytów}

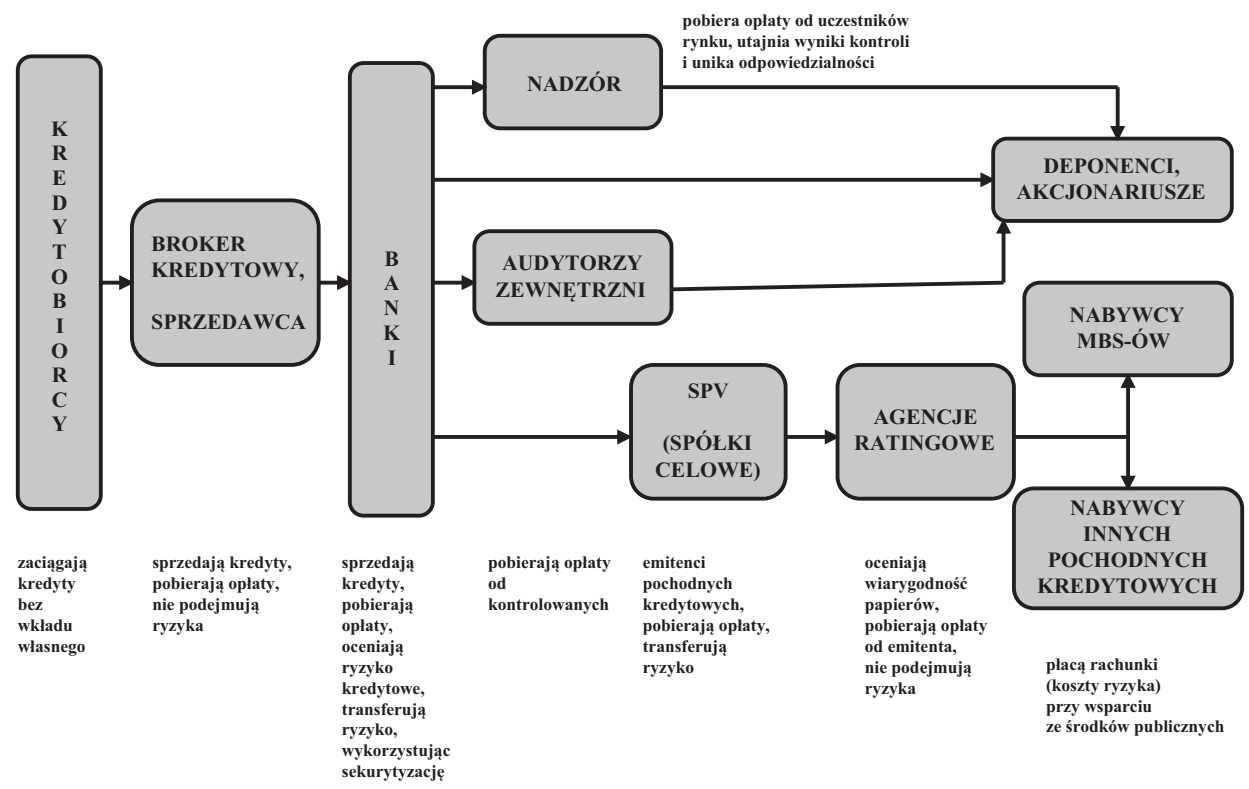

Źródło: opracowanie własne. 
W łańcuchu tym odbywa się transfer ryzyka kredytowego od kredytobiorców, poprzez pośredników kredytowych, do banków, a następnie z banków, poprzez spółki celowe, na rynki finansowe, aż do nabywców pochodnych kredytowych, którzy, nie mając „zielonego pojęcia” o zarządzaniu ryzykiem kredytowym, ponoszą konsekwencje chciwości i niefrasobliwości wielu uczestników rynku finansowego.

Moral hazard uprawiają sprzedawcy i brokerzy kredytowi przedstawiający się jako „doradcy”. Doradcy ci wynagradzani są jednak przez kredytodawców, a nie kredytobiorców, którym „doradzają”. Co więcej wynagradzani są najczęściej w formule akordowej, pobierając prowizje od sprzedawanego kredytu.

Doradca doradzi jak dopasować się do wymogów procedur scoringowych banku, który oferuje mu najwyższą prowizję. Działa w klasycznym konflikcie interesów, który „ma miejsce wówczas, gdy człowiek zobowiązany jest w wyniku zewnętrznych okoliczności lub własnych działan, do podwójnej lojalności” (Lewicka-Strzałecka, 2015).

Moral hazard uprawiają banki pobierające opłaty i transferujące ryzyko kredytowe wraz ze sprzedażą portfela kredytowego do SPV. Koszty ryzyka pokryją nabywcy emitowanych przez SPV instrumentów finansowych.

Filarami wiarygodności systemu są:

- agencje ratingowe opłacane przez emitentów,

- audytorzy opłacani przez kontrolowanych,

- nadzór finansowy utajniający oceny.

Wiarygodność emitowanych instrumentów finansowych oceniana jest przez agencje ratingowe, ale mimo że beneficjentem tych ocen powinni być inwestorzy, agencje wynagradzane są jednak przez emitentów. Podobnie wiarygodność sprawozdań finansowych banku dla wierzycieli i akcjonariuszy oceniana jest przez audytorów zewnętrznych, ale wynagradzani są oni przez ocenianego. Co więcej, świadczą dla niego zazwyczaj szereg usług konsultingowych. Znajdują się w podobnej sytuacji, jak nauczyciel udzielający korepetycji uczniowi, którego później egzaminuje. Są to klasyczne konflikty interesów, które nie pozwalają przezwyciężyć kryzysu zaufania na rynkach finansowych. Jedyną instytucją, która nie jest w sytuacji konfliktu interesów jest nadzór bankowy, wynagradzany przez uczestników rynku w formie obowiązkowej składki. Utajnia on jednak wyniki swoich ocen i kontroli. Unikając odpowiedzialności, nie jest w stanie ograniczyć kryzysu zaufania na rynkach finansowych. Przykładem utraty zaufania na rynkach finansowych jest sytuacja na rynku międzybankowym, na którym praktycznie nie 
zawiera się transakcji na okresy dłuższe niż tydzień, a stopy referencyjne (LIBOR, EURIBOR, WIBOR) nie mają od kilku lat charakteru rynkowego. Zniekształca to wycenę instrumentów finansowych i pogłębia kryzys zaufania.

Moral hazard $\mathrm{w}$ połączeniu $\mathrm{z}$ konfliktem interesów powoduje ograniczenie działania mechanizmów rynkowych. Moral hazard w pośrednictwie finansowym wzmacniany jest nie tylko przez permanentny konflikt interesów instytucji, które powinny uwiarygadniać system finansowy, w szczególności firm audytorskich i agencji ratingowych, lecz także przez asymetrię informacji. Asymetria informacji oraz związana z nią pokusa nadużycia szczególnie widoczne są w przypadku dystrybucji produktów bardziej skomplikowanych. Pośrednik finansowy, mający na celu zwiększenie sprzedaży, może świadomie prowadzić do sytuacji, gdzie klient będzie miał ograniczony dostęp do rzetelnych informacji o usłudze lub zostanie przytłoczony nadmiarem informacji, wynikających często z regulacji ostrożnościowych oraz natarczywej reklamy. Asymetria informacji i moral hazard ze strony pośredników finansowych doprowadziły m.in. do problemów związanych z nadmiernym zadłużeniem w kredytach denominowanych we frankach szwajcarskich czy też problemów związanych ze sprzedażą tzw. opcji walutowych zerokosztowych.

Rysunek 2. Moral hazard a kryzys zaufania

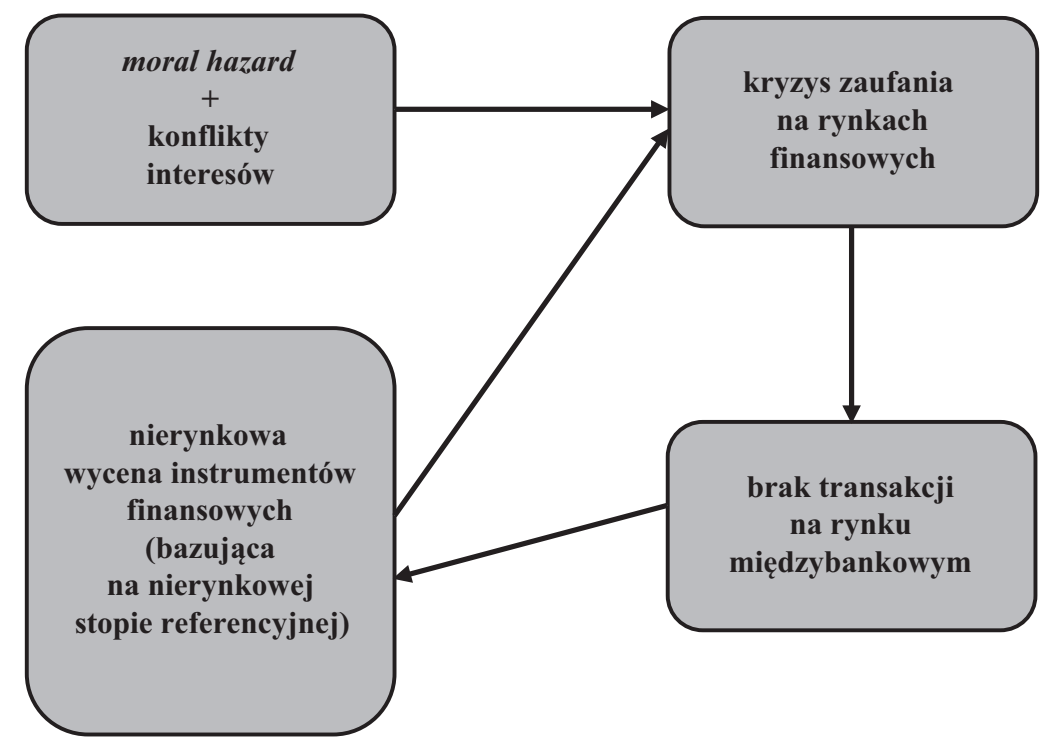

Źródło: opracowanie własne. 
Mikroekonomiczny mechanizm funkcjonowania sektora bankowego o relatywnie wysokim poziomie moral hazard kumuluje się z moral hazard w skali makro.

W skali makro uprawiają go głównie przedsiębiorstwa zbyt duże by upaść, głównie banki, politycy populiści, a także banki centralne postępujące jak twórcy piramid finansowych.

W Europie niewypłacalne duże banki, które zbankrutować nie moga, wspierane są przez bankrutujące kraje, które zadłużają się w bankrutujących bankach i dotowane są przez Europejski Bank Centralny. Usiłuje on zmniejszyć ryzyko rozpadu strefy euro i, pod pozorem ratowania płynności systemu bankowego, dotuje banki eurolandu w ramach operacji LTRO (Long Term Refinancing Operation), w oczekiwaniu na decyzje i rozwiązania systemowe, które nie mogą być skutecznie podjęte przez polityków, ponieważ dotyczą kosztów ryzyka i podziału strat, a nie populistycznych obietnic.

\section{Rysunek 3. Moral hazard wbudowany w system społeczno-gospodarczy}

\section{Hazard wbudowany w system}

bankrutujące banki wspierane są przez

bankrutujące kraje, które zadłużają się

w bankrutujących bankach, które dotuje

Europejski Bank Centralny

\section{Kto przejmie ryzyko?}

Źródło: opracowanie własne.

Niemoralny moral hazard wbudowany jest w system polityczny, w którym mechanizm zdobywania i utrzymania władzy stwarza presję na wzrost ryzyka dla bezpieczeństwa finansów publicznych. Moral hazard kreowany przez transgraniczne banki - zbyt duże, aby upaść i zbyt duże, aby je uratować - pogłębia ryzyko dla bezpieczeństwa finansów publicznych. Dodatkowo trudno przewidzieć, w którym kraju nastąpi nacjonalizacja strat. Korzyści z hazardu mają bowiem wymiar ponadnarodowy, a koszty ryzyka - narodowy.

Ostatnie lata pokazały, że w Europie ma miejsce wyjątkowo groźne sprzężenie zwrotne moral hazard kreowanego przez banki too-big-to-fail (TBTF) 
oraz przez populistycznych polityków. Będący wyrazem populizmu polityków wysoki dług publiczny znajdował swoje odzwierciedlenie w obniżeniu jakości aktywów banków, posiadających w swoich portfelach obligacje rządowe.

Skutki tego fatalnego sprzężenia zwrotnego, w którym coraz bardziej niewypłacalne kraje zadłużały się w coraz bardziej niewypłacalnych bankach, zostały odroczone przez powołanie Europejskiego Mechanizmu Stabilizacji Finansowej, który w intencji jego twórców powinien przyczynić się do przerwania sprzężenia między zadłużeniem rządów a sytuacją banków1. W ostatecznym kształcie ESM ma dysponować kapitałem 700 mld euro (z tego 620 mld euro to kapitał na żądanie) i będzie najprawdopodobniej największą globalną instytucją finansową. Do tej pory z pomocy ESM skorzystały Hiszpania i Cypr. Nie negując zasadności powołania ESM, warto zauważyć, że stanowi on kolejne zabezpieczenie dla banków i rządów przed ryzykiem rynkowym i groźbą bankructwa. Może zatem spowodować, że moral hazard banków TBTF przeniesiony zostanie ze szczebla narodowego na europejski.

Generalnie system ograniczający nadmierne ryzyko dla decydentów w gospodarce rynkowej, gospodarce, której cykliczny rozwój oparty jest na „chciwości” i „strachu” przed skutkami nieodpowiedzialnych działań, prowadzi do poczucia bezkarności, narastania moral hazard, kryzysu zaufania i ryzyka systemowego.

\section{Rysunek 4. Przerwać zaklęty krąg}

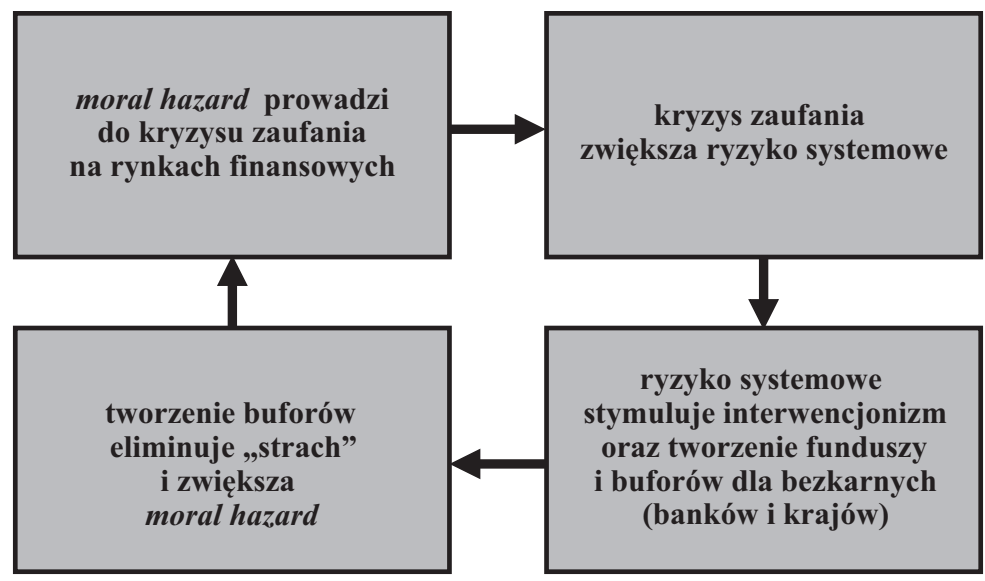

Źródło: opracowanie własne.

1 European Stability Mechanism (ESM) został powołany w 2012 roku traktatem podpisanym przez 17 państw eurolandu, głównie z obawy przed rozpadem strefy euro (ESM, 2018). 


\section{Czy nowe regulacje antymonopolistyczne i ostrożnościowe ograniczą niemoralny moral hazard?}

Odpowiedzią na narastający moral hazard w wymiarze transgranicznym jest koncepcja Unii Bankowej, regulacje wzmacniające ochronę konsumentów oraz wzmacniające wiarygodność banków i stabilność systemu bankowego (por. też KE, 2012).

Idea Unii Bankowej nie jest nowa. Oznacza $\mathrm{w}$ istocie przeniesienie na szczebel ponadnarodowy zarówno nadzoru nad sektorem bankowym, jaki i odpowiedzialności fiskalnej.

Unia Bankowa ma być oparta na trzech filarach:

- jednolitych ramach dla nadzoru bankowego (SSM);

- mechanizmie restrukturyzacji i uporządkowanej likwidacji banków, tzw. resolution mechanism, finansowanym przez sam sektor, a nie ze środków podatników;

- wspólnym systemie gwarancji depozytów.

Istnieje jednak wysokie ryzyko niedokończenia realizacji projektu Unii Bankowej w części związanej z przeniesieniem odpowiedzialności fiskalnej na szczebel ponadnarodowy, zarówno jeśli chodzi o utworzenie adekwatnego do zagrożeń europejskiego resolution fund, jak i europejskiego scentralizowanego modelu gwarantowania depozytów.

Nawet jeśli koncepcja Unii Bankowej zostałaby w pełni zrealizowana, oznaczałoby to de facto taką konstrukcję Unii Bankowej, która powodowałaby przeniesienie moral hazard na szczebel ponadnarodowy i odraczała w czasie ryzyko ponadnarodowej katastrofy, ale na znacznie większą skalę.

Wydaje się, że są tylko dwie rozsądne drogi na rozwiązanie tego problemu:

- pierwsza - to podział banków TBTF na jednostki mniejsze, które mogaz zbankrutować, nie powodując istotnego zagrożenia dla stabilności systemu finansowego; podział banków TBTF jest trudny do realizacji w europejskich uwarunkowaniach;

- druga - to opracowanie specjalnych procedur likwidacji banków TBTF, które nie destabilizowałyby systemu finansowego.

Jak dotychczas ta druga droga, tzw. resolution, dominowała w regulacyjnych inicjatywach rozwiązania problemu moral hazard kreowanego przez banki TBTF. Financial Stability Board w listopadzie 2011 roku opublikowała dokument, pn. „Key Attributes of Effective Resolution Regimes for Financial Institutions" (FSB, 2014), zawierający zasady, które powinny uwzględniać 
regulacje dotyczące restrukturyzacji i uporządkowanej likwidacji banków. Zasady te wykorzystane zostały przez Komisję Europejską, która opracowała dyrektywę BRR mającą na celu harmonizację regulacji prawnych krajów członkowskich UE w zakresie resolution. Proces resolution wg dyrektywy BRR ma zagwarantować taką restrukturyzację lub likwidację niewypłacalnego banku o znaczeniu systemowym, która zapewni ciągłość funkcji krytycznych banku² i ochronę finansów publicznych oraz deponentów objętych zakresem dyrektywy 2014/49/UE.

Dyrektywa BRR nie rozwiązuje jednak głównego problemu związanego $\mathrm{z}$ realną możliwością wykorzystania procedury resolution $\mathrm{w}$ stosunku do największych instytucji finansowych, tzw. G-SIBs. Sprowadza się on do pytania, kto zapłaci za niewypłacalność dużych transgranicznych instytucji finansowych (G-SIBs). Przewidziane w dyrektywie środki na finansowanie procesu resolution są skromne. Narodowe fundusze resolution powinny osiągnąc docelowo poziom 1\% depozytów gwarantowanych. European Resolution Fund, tzw. jednolity fundusz restrukturyzacji i uporządkowanej likwidacji będzie tworzony przez 8 lat i szacuje się, że jego środki wyniosą docelowo ok. $55 \mathrm{mld}$ euro. Są to środki dalece niewystarczające do skutecznego przeprowadzenia uporządkowanej likwidacji nawet pojedynczych G-SIBs, nie wspominając o kosztach ryzyka systemowego w sytuacji niewypłacalności kilku takich instytucji. Na marginesie warto zauważyć skalę dysproporcji między docelową kapitalizacją Funduszu EMS (700 mld euro) przeznaczonego, jak dotychczas, na ratowanie niewypłacalnych banków a kapitalizacją European Resolution Fund (55 mld euro) przeznaczonego w części na likwidację banków TBTF³.

European Resolution Fund stanowi z punktu widzenia stabilności systemu finansowego uzupełnienie kapitałów własnych banków oraz tych zobowiązań, które w sytuacji kryzysowej mogą odgrywać tę sama rolę dla pozostałych wierzycieli co kapitał własny. Stanowi wzmocnienie buforów bezpieczeństwa

2 Przez funkcje krytyczne rozumie się „taki rodzaj działalności pełnionej przez daną instytucję na rzecz strony trzeciej, która jest istotna dla funkcjonowania sfery realnej, gospodarki i dla utrzymania stabilności finansowej, a nagły brak lub zaburzenie w dostępności tej funkcji może mieć znaczny negatywny wpływ na strony trzecie, a także może być źródłem spadku ogólnego zaufania uczestników rynku” (por. Szczepańska, Dobrzańska i Zdanowicz, 2015).

3 Dodajmy, że Fundusz EMS tworzony jest ze środków publicznych, a European Resolution Fund ze środków prywatnych banków. Podstawą naliczania składki na jednolity fundusz restrukturyzacji i uporządkowanej likwidacji mają być zobowiązania banku pomniejszone o fundusze własne i depozyty gwarantowane, skorygowane o ryzyko podejmowane przez bank. Podstawą naliczania składki na Fundusz EMS jest klucz kapitałowy EBC, czyli średnie arytmetyczne z udziału poszczególnych państw w liczbie ludności i PKB w strefie euro. 
dla części wierzycieli i klientów banków w przypadku jego niewypłacalności. Podwyższa to niewątpliwie zaufanie do sektora bankowego, a co najważniejsze przenosi ze szczebla narodowego na europejski część odpowiedzialności za decyzje, które będą zapadały na szczeblu ponadnarodowym. Największą zaletą tego rozwiązania jest zatem próba przeniesienia kompetencji i odpowiedzialności na ten sam szczebel decyzyjny.

Rozwiązanie to wiąże się $\mathrm{z}$ ryzykiem innego typu. Tworzenie funduszy resolution na szczeblu narodowym czy ponadnarodowym jest alternatywa dla wyższych wymagań kapitałowych wobec indywidualnych banków. Te same środki mogłyby zostać bowiem przeznaczone na uzupełnienie kapitałów własnych poszczególnych banków. Wówczas pokusa nadużycia (hazard moralny) byłaby mniejsza. Tworzenie wspólnych funduszy gwarantujących bezpieczeństwo dla otoczenia, a szczególnie dla wierzycieli, osłabia bowiem dyscyplinę rynkową i może, w przypadku pojedynczych banków, stymulować zjawisko określane mianem free rider. Fundusze resolution mogą być postrzegane w pojedynczych bankach nie jako uzupełnienie kapitałów własnych, lecz jako ich substytut.

Jeśli obok skromnego europejskiego resolution fund pozostałby na szczeblu federalnym głównie Europejski Mechanizm Stabilizacyjny (ESM), którego misją nie jest umożliwienie upadłości lecz - przeciwnie - wspieranie banków kreujących (tworzących) ryzyko systemowe, konstrukcja Unii Bankowej powielałaby błędy systemu centralnego planowania.

W warunkach przedłużającego się kryzysu zaufania na rynkach finansowych należy docenić inicjatywy Financial Stability Board (FSB) (FSB, 2014a), które koncentrują się wokół redukcji skłonności do moral hazard przez największe transgraniczne instytucje finansowe. Inicjatywy te stanowią uzupełnienie Trzeciej Bazylejskiej Umowy Kapitałowej (Bazylea III). Bazylea III obejmuje co prawda kwestie dotyczące dodatkowego wyposażenia banków w kapitały własne i ich jakości, a także normy płynności i politykę ujawnień i nadzoru, które powinny ograniczyć ryzyko systemowe, ale nie zawiera regulacji dotyczących działania instytucji ważnych systemowo w skali globalnej.

Moral hazard w połączeniu z ryzykiem systemowym, głównie transgranicznym, stanowi ważne wyzwanie dla stabilności globalnego systemu finansowego, stąd zasadne wydaje się skoncentrowanie działań na poziomie FSB i G-20.

W Unii Europejskiej problem banków TBTF jest szczególnie istotny z powodu silnego uzależnienia gospodarki europejskiej od bankowych źródeł finansowania, a także niespotykanie wysokiej relacji aktywów banków do PKB. Relacja ta wynosi ok. 350\% PKB i jest znacząco większa niż w innych 
wysoko rozwiniętych gospodarkach (szerzej: Szczepańska, Dobrzańska i Zdanowicz, 2015).

Propozycja FSB zakłada wprowadzenie dodatkowych wymogów ostrożnościowych wobec trzydziestu największych banków, które zostaną uznane za najważniejsze w świetle kreowanego przez nie ryzyka systemowego. Wymogi te, określone mianem zdolności do całkowitej absorpcji strat (total loss absorbency capacity, TLAC), mają na celu zwiększenie możliwości rekapitalizacji banków w sytuacji ich uporządkowanej restrukturyzacji i likwidacji (resolution). W liście do przywódców zgromadzonych na spotkaniu G20 Mark Carney, Przewodniczący FSB, użył zwrotu ending too big to fail (skończyć ze „zbyt dużymi by upaść).

Zgodnie z propozycją, Globalne Systemowo Ważne Banki (G-SIBs) wskazane przez FSB, powinny począwszy od 1 stycznia 2019 r. dysponować rezerwą instrumentów kapitałowych i dłużnych o wartości co najmniej 16-20 proc. aktywów ważonych ryzykiem, które mogłyby zostać skonwertowane na kapitał w sytuacji kryzysowej.

Dodatkowym wymogiem jest, aby rezerwa ta była na poziomie co najmniej dwukrotności wskaźnika dźwigni stanowiącej inne narzędzie oceny adekwatności kapitałowej banku, niezależne od poziomu ryzyka finansowego. Proponowana rezerwa winna zapewnić kontynuowanie funkcji krytycznych banku w procesie jego uporządkowanej likwidacji oraz chronić podatników przed ponoszeniem kosztów takiej upadłości poprzez eliminowanie konieczności stosowania mechanizmu bail-out przez bank centralny bądź rząd.

Zdaniem ekspertów Europejskiego Kongresu Finansowego (EKF, 2015) projekt TLAC może ograniczyć moral hazard generowany przez G-SIBs, ale go nie wyeliminuje ${ }^{4}$.

Reasumując, nowe regulacje antymonopolowe, a szczególnie dyrektywa BRR, a także regulacje mające na celu ograniczenie poziomu dźwigni finansowej (TLAC i MREL), mają charakter prorynkowy i starają się ograniczyć ryzyko systemowe i moral hazard tworzone przez banki TBTF. Wdrażane są jednak w systemie obfitującym w konflikty interesów, co nie pozwala optymistycznie patrzeć w przyszłość.

${ }^{4}$ Ekspertyza grupowa przeprowadzona została przez autora niniejszego rozdziału za pomocą zmodyfikowanej metody delfickiej oraz przesłana do FSB jako opinia ekspertów Europejskiego Kongresu Finansowego. Wyniki badań i metodologię można znaleźć na stronie: https://www.efcongress.com/sites/default/files/2_stanowisko_ekf_dot._tlac.pdf oraz w artykule (Pawłowicz i Broniewski, 2015). 
Również regulacje wzmacniające ochronę konsumenta, wydają się tworzyć ogromną biurokrację, gąszcz instrukcji i regulaminów mających na celu głównie spełnienie wymogów formalnych przez pośredników finansowych. Nie wprowadzają dyscypliny rynkowej i funkcjonują w systemie motywacyjnym ukierunkowanym na wzrost sprzedaży i prowizyjnym wynagradzaniu. Nie niwelują konfliktu interesów ani moral bazard w pośrednictwie finansowym.

Wdrożeniem prorynkowych rozwiązań następuje zatem w warunkach asymetrii informacji i systemowego konfliktu interesów instytucji, które powinny uwiarygadniać system. Trudno więc oczekiwać istotnego przełomu w ograniczaniu moral hazard i ryzyka systemowego w obecnym ładzie instytucjonalnym.

\section{Literatura}

Barembruch, A. (2007). Modele współpracy pośredników kredytowych z bankami. W: A. Barembruch, E. Gostomski, B. Lepczyński, M. Penczar (red.), Pośrednictwo kredytowe - podręcznik dla praktyków (s. 87-101). Warszawa: CeDeWu.

Belka, M. (2015). Praca w systemie finansowym nie powinna być wyzwaniem moralnym. Pozyskano z: https://www.obserwatorfinansowy.pl/tematyka/bankowosc/praca-w-systemie-finansowymnie-powinna-byc-wyzwaniem-moralnym/.

Dembe, A. i Boden, L. (2000). Moral Hazard: A Question of Morality?. New Solutions A Journal of Environmental and Occupational Health Policy, 10(3), 257-79.

EKF. (2015). Koniec zasady „too big to fail”. Rekomendacja Europejskiego Kongresu Finansowego. Pozyskano z: http://www.efcongress.com/pl/koniec-zasady-too-big-fail (24.07.2018).

ESM. (2018). Factsheet - European Stability Mechanism. Pozyskano z: https://www.esm.europa. eu/sites/default/files/20180530esmfactsheet.pdf (24.07.2018).

FSB. (2014). Key Attributes of Effective Resolution Regimes for Financial Institutions. Pozyskano z: http://www.fsb.org/wp-content/uploads/r_111104cc.pdf (24.07.2018).

FSB. (2014a). Adequacy of loss-absorbing capacity of global systematically important banks in resolution. Consultating. Document 10 November 2014. Pozyskano z: http://www.fsb.org/wp-content/ uploads/TLAC-Condoc-6-Nov-2014-FINAL.pdf (24.07.2018).

KE. (2012). Komunikat Komisji Europejskiej „Plan działania na rzecz pogłębionej i rzeczywistej unii gospodarczej i walutowej" 30.11.2012. Bruksela: Komisja Europejska. Pozyskano z: https:// eur-lex.europa.eu/legal-content/PL/TXT/PDF/?uri=CELEX:52012DC0777R(01)\&from =PL (24.07.2018).

Klepczarek, E. (2015). Czy hazard moralny jest zaresze niemoralny. Pozyskano z: http://zbp.pl/public/ repozytorium/wydarzenia/images/czerwiec_2015/cosgrove/Praca_Emilii_Klepczarek.pdf.

Krugman, P. (2009). The return of Depression Economics and the Crisis of 2008. Nowy Jork: W.W. Norton\&Company Inc.

Lewicka-Strzałecka, A. (2005). Teoretyczne i praktyczne aspekty identyfikacji i ograniczania konfliktu interesów. W: A. Węgrzecki (red.), Konflikt interesów - konflikt wartości (s. 7-23). Kraków: Wydawnictwo Akademii Ekonomicznej.

Pawłowicz, L. (2015). Systemy wynagrodzeń ukierunkowane na wzrost wartości przedsiębiorstwa. W: J.K. Bielecki, L. Pawłowicz (red.), Zarzązanie wartościa spótki kapitatowej (s. 305-324). Warszawa: CeDeWu. 
Pawłowicz, L. i Broniewski, R. (2015). Nowe propozycje tylko ogranicza moralny bazard w bankach. Pozyskano z: http://www.obserwatorfinansowy.pl/tematyka/bankowosc/nowe-propozycjeogranicza-moralny-hazard-ale-go-nie-wyeliminuja/ (17.02.2015).

Szczepańska, O., Dobrzańska, A. i Zdanowicz, B. (2015). Resolution, czyli nowe podejście do banków zagrożonych upadtościa (s. 23). Warszawa: NBP.

Wikipedia.org. (2018). Moral hazard. Pozyskano z: https://en.wikipedia.org/wiki/Moral_hazard. Wikipedia.org. (2018a). Volenti non fit iniuria. Pozyskano z: https://pl.wikipedia.org/wiki/Volenti_ non_fit_iniuria. 



\section{Wptyw regulacji $i$ obciązeń finansowych na sektor bankowy w UE $i$ w Polsce ${ }^{1}$}

Reakcja na kryzys lat 2007-2008 byta fala regulacji sektora bankowego, majacych na celu poprawe jego bezpieczeństwa. Rozczarowanie częściowa zawodnościa rozwiazań Bazylei I i II oraz presja polityczna uruchomity liczne regulacje globalne, regionalne $i$ krajowe - nie zawsze spójne w zakresie rozwiazań $i$ roymogów. Tylko UE roydata okoto 60 wiodacych aktów prawnych, a także tysiace stron regulacji wdrażajacych $i$ standardów technicznych (RTS). Skala i szczegótowość biurokratycznych regulacji spotyka sie $z$ coraz szersza krytyka, ponieważ wywiera bezpośredni wptyw na liczone w miliardach dolarów koszty wdrażania ztożonych systemów, koszty raportowania $i$ rosnace wymogi kapitatowe ograniczajace zdolność sektora bankowego do rozwoju biznesu i finansowania jego potrzeb rozwojowych. Różnice regionalne i między krajami, a także między bankami $i$ innymi sektorami finansowymi w zakresie wdrażanych rozwiazań wywotuja liczne napięcia regulacyjne, powodujace arbitraż międzysektorowy $i$ rosnace ryzyko nadmiernej kompleksowości zarządzania. Rozwiazania biurokratyczne nie znalazty wiarygodnych uzasadnieńn w teorii ekonomii $i$ wynikaja raczej z doświadczenia $i$ przekonań legislatorów. Pojawia się pytanie badawcze, czy krańcowy poziom bezpieczeństwa banków nie przekracza krańcowego kosztu wdrażanych regulacji? Analiza empiryczna banków UE i specyficznie banków polskich wskazuje, że wokresie wdrażania regulacji sytuacja sektora bankowego uległa pogorszeniu, co wywiera również negatyrwny wptyw na znaczenie banków w rozwoju gospodarczym.

Słowa kluczowe: banki UE i Polski, regulacje bankowe, sektor bankowy.

* Dr hab. Krzysztof Kalicki, prof. ALK - Akademia Leona Koźmińskiego.

1 Rozdział stanowi addendum do opublikowanego rozdziału książki Grzegorza W. Kołodko pt. Management and Economic Policy for Development (Kalicki i Antczak, 2014). 


\section{THE IMPACT OF REGULATIONS AND FINANCIAL BURDENS ON THE BANKING SECTOR IN THE EU AND IN POLAND}

The 2007/8 crisis brought a response in the form of a wave of regulations in the banking sector, aimed at improving its security. Disappointment with the partial undependability of the Basel I and II solutions and the political pressures triggered numerous global, regional and national regulations which were not always consistent as regards the solutions and requirements. The EU only issued around 60 leading legal acts and thousands of pages of implementing regulations and technical standards (RTS). The scale and level of detail of the bureaucratic regulations is often received with widespread criticism because it exerts direct impact on the costs of implementation of complex systems and reporting costs amounting to billions of dollars, and the increasing capital requirements restrain the banking sector's ability to grow business and finance its development needs. The differences between regions and countries and between banks and other financial sectors as regards the implemented solutions cause numerous regulatory tensions, leading to inter-sectoral arbitrage and increasing risk of excessive complexity of management. The bureaucratic solutions did not find plausible justification in economic theory and follow rather from the experience and convictions of the legislators. An academic question arises whether the marginal level of banks' security does not exceed the marginal cost of the implemented regulations. An empirical analysis of $E U$ banks and, specifically, Polish banks indicates that during the implementation of the regulations the situation of the banking sector deteriorated, which also bas negative impact on the significance of banks in economic development.

Keywords: banks in EU and Poland, banking regulations, banking sector.

JEL: G21, G28, K23

\section{Wprowadzenie}

Źródłem i przyczyną fali regulacji był kryzys subprime z 2008 roku, który spowodował zaangażowanie finansów publicznych na kwoty: USA 1,6 biliona USD; UE 1,5 biliona EUR, powiększając tym samym drastycznie dług publiczny. Ujawniły się nowe rodzaje zagrożeń wychodzące poza zarządzane do tej pory ryzyko biznesowe, ale pojawiły się również sytuacje nadzwyczajne, np. wrażliwość na zarażanie się kryzysami ujawniającymi się w innych krajach, a nawet na innych kontynentach. Kryzys wskazał na niedostateczne kapitały i płynność w sektorze bankowym. Rozczarowanie Bazyleą I i Bazyleą II spowodowało uruchomienie uzupełniających się i pogłębiających regulacji odnoszących się do wymogów kapitałowych i płynnościowych, nakładając na sektor bankowy wysokie obciążenia, powodujące wzrost nie tylko kosztów finansowych, lecz także kosztów implementacyjnych, które wywierają wpływ na sytuację makroekonomiczną - droższy koszt finansowania, ogranicza- 
nie kredytowania, arbitraż regulacyjny. Kryzys gospodarczy lat 2007-2008 spowodował wśród polityków prostą reakcję biurokratyczną w formie fali regulacyjnej, gdzie Bazyla III i CRD IV stały się tylko początkiem nakładania kaftanów bezpieczeństwa przez polityków na banki. Sformułowano wiele agresywnych względem sektora bankowego opinii i postulatów - shrink the banks, put bankers in straitjackets, "własność finansowa ma być sługą”, „już nigdy podatnik nie będzie ratował upadających banków”, „na globalnym rynku regulacje muszą być globalne” i bardziej radykalne - „długi są fikcją trzeba je skasować - banki odpowiadają za dług”, „bankom odebrać marchewkę i uruchomić kij regulacyjny”. Regulacje biurokratyczne stały się podstawową odpowiedzią na kryzys. UE do $2018 \mathrm{r}$ wydała około 60 aktów prawnych, a także dziesiątki tysięcy stron regulacji wdrażających i technicznych.

Liczne regulacje mają swoje implikacje kosztowe i biznesowe, a formalne bezpieczeństwo instytucji w sposób oczywisty implikuje wysokie koszty alternatywne. Ten proces miał widoczne skutki nie tylko w USA i UE, lecz także w wielu innych krajach (Hanke, 2012). Niektóre z nich implementowały regulacje w sposób ostrzejszy od wymagań bazylejskich. W Polsce w minionych latach wymagania KNF nakładały ciężary większe niż ponosiły kraje Europy Zachodniej, obniżając rentowność sektora bankowego, ale i tworząc bariery dla rozwoju biznesu. Obserwuje się negatywne zjawisko tak zwanego „domiaru regulacyjnego” oraz arbitrażu regulacyjnego. Dalszą odpowiedzią na kryzys jest więc kolejne zwiększenie szczegółowości regulacji i raportowania, co, jak będę chciał wykazać, szkodzi dziś rozwojowi kraju.

Nadmierne lub niewłaściwe regulacje powodują arbitraż regulacyjny i przesuwają część biznesu do innych geograficznie regionów lub do shadow banking, czego symbolem w Polsce (nie jedynym) była afera Amber Gold czy ostatnio Getback. To zjawisko narasta również w innych krajach w postaci bardzo dużego wzrostu aktywów finansowych różnego rodzaju funduszy i pośredników finansowych, przy relatywnej stagnacji sektora bankowego. Do dziś nie pojawiła się silnie uzasadniona teoretycznie i praktycznie odpowiedź, jaki powinien być kapitał własny banku. $\mathrm{Na}$ to pytanie nie odpowiedziano ani przy wdrażaniu Bazylei III, ani przy projektowaniu już Bazylei IV, a co wywiera znaczący wpływ na zyskowność inwestycji w tym sektorze oraz zdolność sektora do konkurowania o kapitał na rynkach finansowych.

Problem ten jest już dostrzegany. Przeciwdziałając temu zjawisku, Prezydent Stanów Zjednoczonych Ameryki Północnej zapowiedział w ostatnim czasie rewizję, a wręcz uchylenie Dodd-Frank Act, który został określony przez służby administracyjne Białego Domu jako „tragiczna regulacja”, która „paraliżuje gospodarkę" zamiast przeciwdziałać przyszłym kryzysom finansowym. Donald 
Trump oskarża Demokratów, że stworzyli legislative Godzilla i chce uchylić 2300 stron tego dokumentu. Podnosi się, że Consumer Financial Protection Bureau wprowadziło 19 statutów chroniących biurokratycznie konsumenta. Koszty Dodd-Frank Act dla jedenastu agencji nadzorujących w USA przekroczyły kwotę 1,2 mld USD w ciągu pierwszych 3 lat (Wehinger, 2012).

Rodzą się uzasadnione pytania: czy krańcowy poziom bezpieczeństwa banków i klientów nie jest zbyt niski w stosunku do krańcowego kosztu wdrażanych regulacji; czy narzucanie modeli bazujących na danych z przeszłości pozwala oszacować potencjalne straty, które mogą się pojawić za 10 czy 20 lat? W globalnym świecie coraz bardziej ryzyko zależy od zdarzeń wynikających z polityki, w tym gospodarczej, będących często pod presją populizmu partii wygrywających w wyborach. W niniejszym rozdziale podjęto analizę skali i kompleksowości regulacji i ich wpływu na rozwój makroekonomiczny, a także analizę ilościową dynamikę zmian w sektorze bankowym UE w kontekście dekady największych wdrożeń regulacyjnych. Następnie podobnej analizie dla tego samego okresu poddano stan polskiego sektora bankowego. Podsumowanie zawiera krytyczne oceny polityków gospodarczych oraz wnioski nasuwające się z obu analiz.

\section{Wyzwania regulacyjne - ocean ich wpływu na rozwój gospodarczy}

Tempo narastania regulacji przeszło wszelkie wyobrażenia ${ }^{2}$, a w ciągu ostatnich lat miało charakter wykładniczy (wykres 1).

Od blisko 10 lat zarządzający bankami poświęcają prawie cały czas zagadnieniom regulacji i ich wdrażania. Jak ocenia Martin Wheatley, były szef FCA, „prezesi zarządów banków około 70\% swojego czasu poświęcają wdrażaniu przepisów (CEO's spend $70 \%$ of their time thinking about regulation E com-

2 Aby uzyskać wyobrażenie o skali regulacji warto zapoznać się z ilustracją problemu: JEDNA REGULACJA CRD IV i CRR - 480 stron - oraz akty implementacyjne; Rozporządzenie wykonawcze Komisji (UE) nr 680/2014 z dnia 16 kwietnia 2014 r. ustanawiające wykonawcze standardy techniczne dotyczące sprawozdawczości nadzorczej instytucji zgodnie z rozporządzeniem Parlamentu Europejskiego i Rady (UE) nr 575/2013 ma 1047 stron i zawiera 17 załączników, z których większość musi być wysyłana do organów nadzorczych w trybie kwartalnym. Tylko Załącznik I, dotyczący funduszy własnych, zawiera 29 arkuszy do wypełnienia, łącznie 1500 wierszy. Tego typu załączników na chwilę obecną jest ponad 20. MIFID i MIFIR mają 210 stron + akty implementujące 500 stron i wytyczne 310 stron, razem MIFID II ma 1250 stron. W ramach EMIR 330 giełd informuje na temat 35 milionów instrumentów. 
pliance)". Wraz z innymi uregulowaniami skala nowo kreowanych przepisów jest historycznie wyjątkowa. Pierwszy dokument Bazylea I w 1988 roku obejmował 30 stron, ostatni projekt dotyczący CRD4 to prawie 700 stron i 78 równań kalkulacyjnych ${ }^{3}$. Pojawia się pytanie, kto tak naprawdę zarządza biznesem bankowym - regulatorzy czy kierownictwo banków. Banki na całym świecie oponują przeciw takim praktykom.

\section{Wykres 1. Wyzwania regulacyjne}

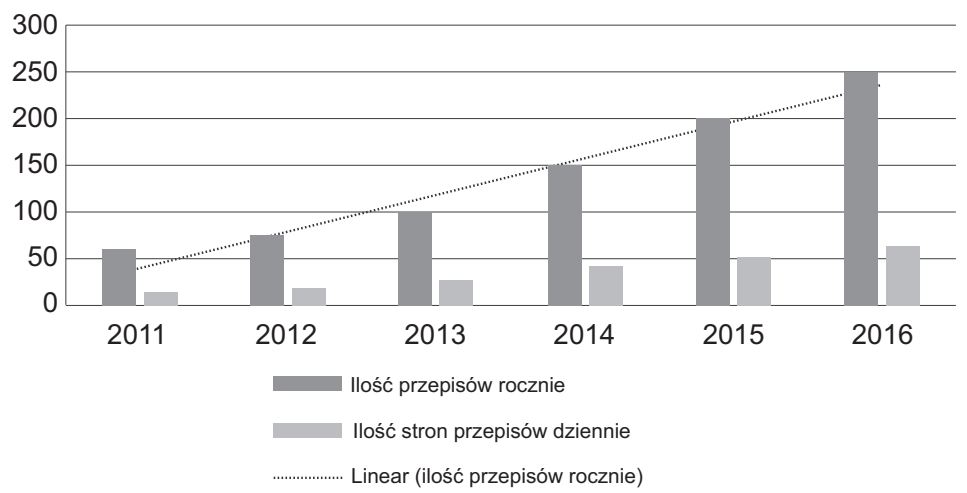

Żródło: BCC, Deutsche Bank Research, 2017.

W Polsce implikacje regulacyjne mają wieloraki i istotnie obciążający biznes bankowy charakter. Koszty i wysiłek organizacyjny zwiększają się znacząco. Wykres 2 pokazuje, jak w stosunku do wzrostu funduszy własnych (implikowanych regulacjami) rósł kredyt dla gospodarki. Przez ostatnie lata kredyt rósł w tempie praktycznie o połowę niższym niż fundusze własne. Ten stan, jak później wskażą inne dane, powoduje gwałtowne obniżenie rentowności biznesu bankowego i ogranicza dostęp do nowych funduszy własnych na rynkach kapitałowych (Slovik i Cournede, 2011; Santos i Elliott, 2012).

Wykresy 2 i 3 wskazują na kumulację regulacji. Warto prześledzić skalę wyzwań regulacyjnych oraz przyjrzeć się źródłom kosztów regulacji i skali ich wpływu na gospodarkę, choć ilość regulacji podstawowych oraz towarzyszących im regulacji oraz standardów wdrożeniowych jest trudna do prześledzenia. W celu ilustracji poniżej przedstawiono tylko najistotniejsze kierunki i regulacje, których akronimy jedynie dla nielicznych specjalistów są czytelne, jednak ich rozwinięcie wykroczyło by poza ramy narzucone przez formę rozdziału.

\footnotetext{
3 CRD4 wersja z 2012 r.
} 
Wykres 2. Dynamika funduszy własnych i kredytu oraz regulacje

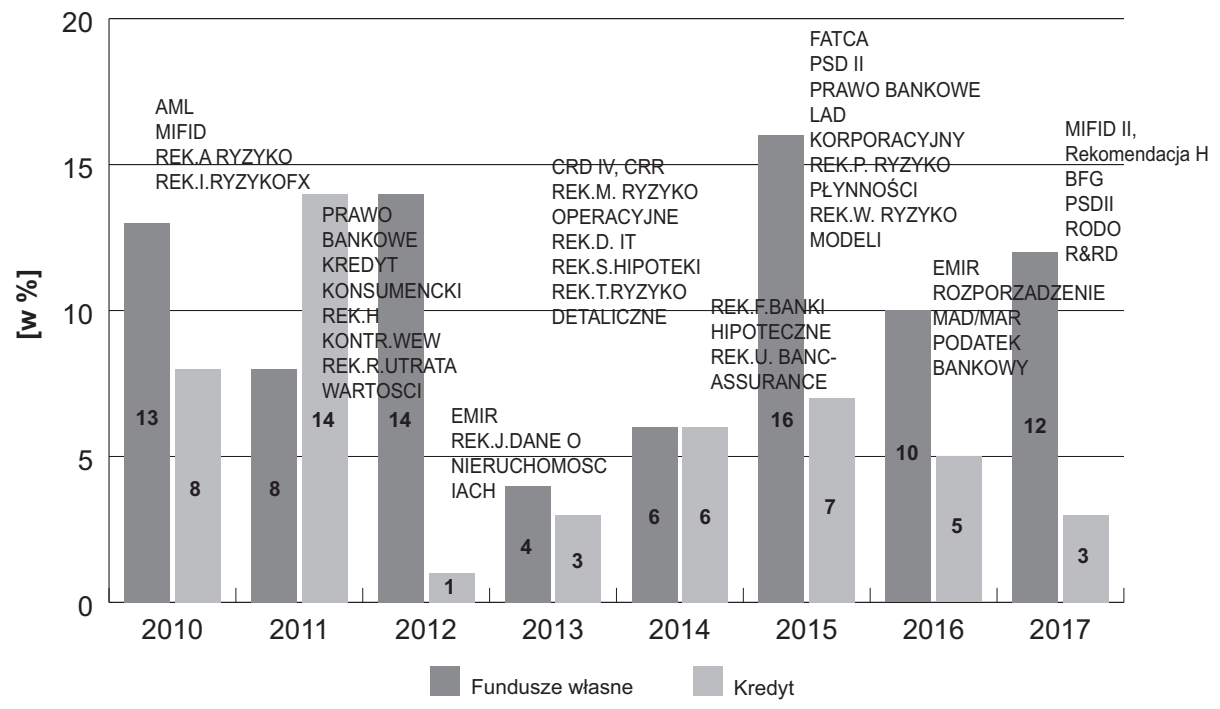

Źródło: opracowanie własne, dane KNF, NBP, regulacje.

\section{Wykres 3. Stała ekspansja regulacji}

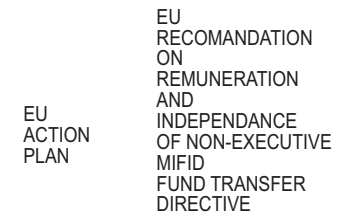

SHAREHOLDERS

RIGHTS MARISK

DIRECTIVE $\quad$ ECB ON RISK

SERP APETITE

GUIDELINES TLAC $16 / 19$

BCBS INSURANCE

PRINCIPLES DISTRIBUTION

FATCA DORECTIVE

MIFIDII MORTGAGE CREDIT

MAD, MAR ILAAP, ICAPDIRECTIVE

$\begin{array}{llll} & \text { BOARDS,EBA } & \text { MIFIDII } & \text { MORT } \\ \text { EU GREEN } & \text { GUIDELINES } & \text { MAD, MAR } & \text { ILAAP, I } \\ \text { PAPER } & \text { CGAP } & \text { CONSUMERRIGH } & \text { EMIR } \\ \text { REMUNERATION } & \text { EMPED } & \text { ISDIRETIVE, } & \text { ROZP }\end{array}$

REMUNERATION CGAP

GOVERNANCE,

TS DIRECTIVE,

PRIP

EAP, ICAPDIRECTIVE

AUDIT POLICY

PAD

ROZPORZAQDZENIE

MAD, MAR PL

CSD2014 PODATEK

REKOMENDACIA INSTYTUCJE KREDYT

$U$ FINANSOWE HIPOTECZNY

\section{$20002001 / 32004 / 52000200920102011201220132014201520162017$}

CPROPRATE

GOVERNANCE

ACTIONN PLAN

PSD

REKOMENDACJA

B, F, G, L

697 STRON REKOMENDACJI KNF

CREDIT
EU GREEN, $\quad$ CRDIV, CRR, LCR, FIT\&PROPER

PRZECIWDZIALANIE GUIDELINES

PRANIU

PIENIEDZY,

REKOMENDACJA

ERS RIGHTS

CONSUMER

DIRECTIVE

A, I

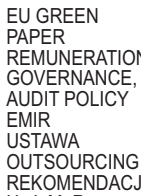

PAD

PAD

BRRD,BRR, MREL/14/15

AML DIRECTIVE

FATCAPL

USTAWA

RACHUNKI

UŚPIONE

CRDIV

POPRAWKA

REKOMENDACJAK,

Z, P,W
$\mathrm{PL}$

$$
\mathrm{H}, \mathrm{J}, \mathrm{M}, \mathrm{R}
$$

Źródło: opracowanie własne. 
Regulacje finansowe rozwijają się w kilku kierunkach (Cornillie, 2017):

- bezpieczeństwo banków i poprawa zarządzania - kapitał, płynność, lewar, ostrożność [Bazylea I, II, III, CRD IV, CRR (kapitały, bufory, płynność LCR, NSFR, CVA, Rekomendacja A, C, M, P), AQR];

- zarządzanie i kontrola [TLAC, MREL, ICAAP, ILAAP, FRTB, Dodd-Frank Voler Rule, German Bank Separation Act, Rekomendacja $\mathrm{H}, \mathrm{M}, \mathrm{Z}]$;

- ochrona inwestorów/deponentów i transparencji transakcji instrumentami finansowymi z klientami [MIFID I, II, SFTR, PRIIP, MAD, MAR, Recovery\&Resolution, GDPR/RODO, Rekomendacja T, S, U];

- infrastruktura oraz transparencja produktów bakowych [SEPA, CCD, CP\&SD, MCD, PAD, PSD II, IDD, RDP];

- kontroli przepływów finansowych i ich raportowania [AML, EMIR, FATCA, CRS, Split payment, STIR, Rekomendacja H];

- inne [UCIT V, AIFMD, Financial Transaction Tax, Podatek Bankowy, IFRS-9].

Na pewno pozytywnym efektem Bazylei I, II, III jest zwiększenie formalnego bezpieczeństwa, ale skutkiem zacieśnienia regulacji i zwiększenia wymogów jest relatywne zmniejszenie akcji kredytowej i wzrost kosztów ponoszonych przez banki. Głównym celem Bazylei III jest poprawa zdolności sektora bankowego do absorpcji szoków wynikających z gwałtownego pogarszania się sytuacji ekonomicznej - bez względu na przyczynę - i redukcja ryzyka rozprzestrzeniania się efektów z sektora bankowego na realną gospodarkę. Bazylea III jest kolejną odpowiedzią regulatorów na niedostatki regulacyjne w zakresie głównie gromadzenia kapitału, stosowanej dźwigni finansowej i płynności banków. Bazylea III wycofuje się częściowo ze swobody danej bankom przez Bazyleę II i ma spowodować skurczenie się sektora finansowego tak, aby zapewnić odpowiednie proporcje w stosunku do sektora realnego. Planowanym terminem wejścia $\mathrm{w}$ życie wszystkich uregulowań pakietu ma być rok 2019.

Dodatkowo bankom uznanym za globalnie i systemowo ważne narzuca się dalsze jeszcze wyższe wymogi kapitałowe. Ponadto, poprawia się także współczynnik wypłacalności po stronie mianownika, dzięki dokonaniu podwyższenia wartości aktywów ważonych ryzykiem (RWA - Risk Weighted Assets) poprzez wprowadzenie narzutu kapitałowego na ryzyko kredytowe pozycji w instrumentach pochodnych (Credit Value Adjustment - CVA).

Kolejną odpowiedzią regulatorów na ostatni kryzys jest pakiet regulacyjny opracowany przez Komitet Bazylejski, tzw. Bazylea III oraz ostatnia, 
znana jako Bazylea 3.5. Głównym czynnikiem, który ma poprawić nowy pakiet regulacyjny jest kolejne podniesienie wymogów kapitałowych oraz wprowadzenie wskaźników płynnościowych dla banków, ograniczenie lewaru, a także nowe wymogi płynnościowe LCR, NSFR. Z pewnością sytuacja na rynkach finansowych jest bardzo złożona i stanowi konsekwencję działania wielu czynników. Już w momencie pojawienia się tego pakietu wskazywano, że skutkiem wprowadzenia pakietu Bazylei III może być poważne osłabienie podaży pieniądza i kredytu, co implikuje osłabienie tempa wzrostu gospodarczego, a w niektórych krajach - wręcz recesję i wzrost bezrobocia. $\mathrm{Z}$ pewnością jeszcze nie wszystkie negatywne efekty regulacji się ujawniły, ze względu na poprawę koniunktury w UE - po wielu latach recesji lub stagnacji. Do roku 2020 oczekuje się ubytku PKB w USA, EU i Japonii między (w punktach procentowych) $-0,3$ a $-0,4 \%$, zatrudnienia zaś od $-0,1$ do $-0,3 \%$ (Angelini, Clerc, Curdia, Gambacorta, Gerali, Locarno, Motto, Roeger, Van den Heuvel i Vlcek, 2011) ${ }^{4}$.

Poniższe dane statystyczne do wykresów dotyczą 47 największych banków UE i pochodzą z DB Research Banks, European Banks Valuation z 2018 r. ${ }^{5}$.

\section{Analiza stanu sektora bankowego w UE}

Banki UE w drugiej dekadzie lat dwutysięcznych przechodziły poważny kryzys biznesowy (recesja lub stagnacja gospodarek) oraz borykały się z wyzwaniami regulacyjnymi pochłaniającymi miliardowe koszty. Jak można zauważyć na wykresie 4, dynamika aktywów i kredytu banków UE była niska, bliska stagnacji, a po roku 2015 oscylowała wokół 1,5\% nominalnie. W 2017 roku suma bilansowa 20 największych banków UE obniżyła się zaś o kolejne $4 \% 6$.

Obroną banków przed rosnącymi wymogami kapitałowymi była redukcja aktywów ważonych ryzykiem poprzez wdrożenie zaawansowanych metod szacowania ryzyka, między innymi wewnętrzne modele ratingowe - tzw. IRB. Badania EBA z 2013 roku, przeprowadzone dla 89 bankowych IRB pokazały, że modele te wykazują duże rozbieżności w wycenach wag ryzyka oraz stosowanych parametrach, które skutkują istotnym obniżeniem poziomu aktywów ważonych ryzykiem i tym samym zmniejszeniem potrzeb kapitałowych banków. Skracając okres zmiennych przyjmowanych do szacowania ryzyka,

${ }^{4}$ IIF staff estimates.

5 DB Research, Banks: European Banks Valuation Weekly, sector aggregate valuation. Report, 9 July 2018

6 DB Research, European Banks. Report, March 19, 2018. 


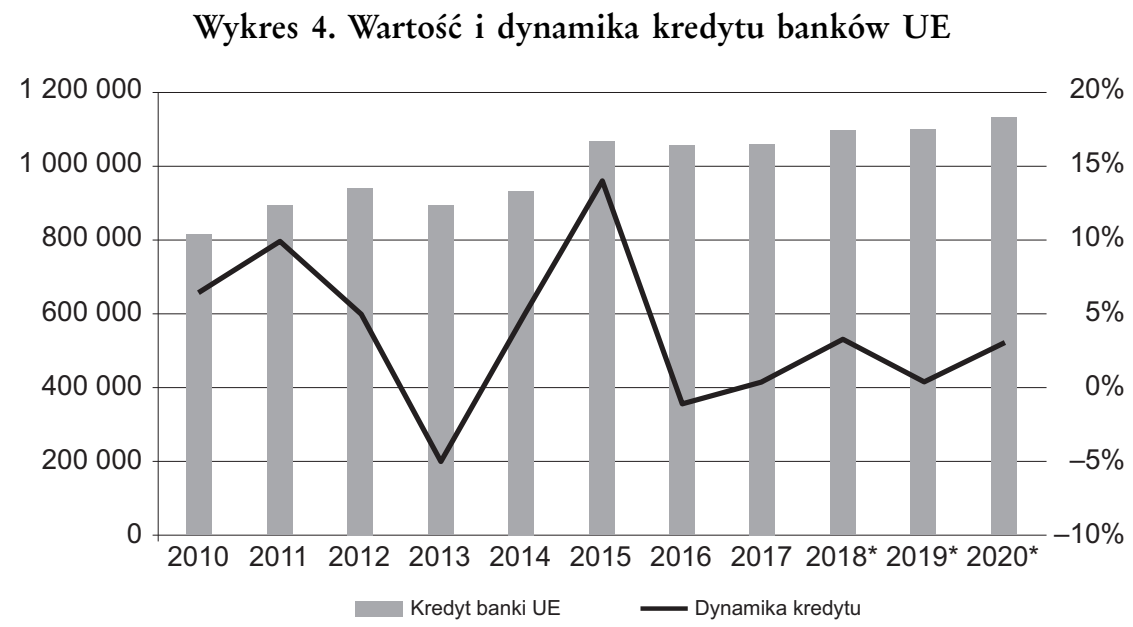

Źródło: opracowanie własne; dane DB Research, Banks: European Banks Valuation Weekly, sector aggregate valuation. Report, 11 June 2018 edition s. 5.

\section{Wykres 5. Aktywa ważone ryzykiem - banki UE - i ich dynamika}

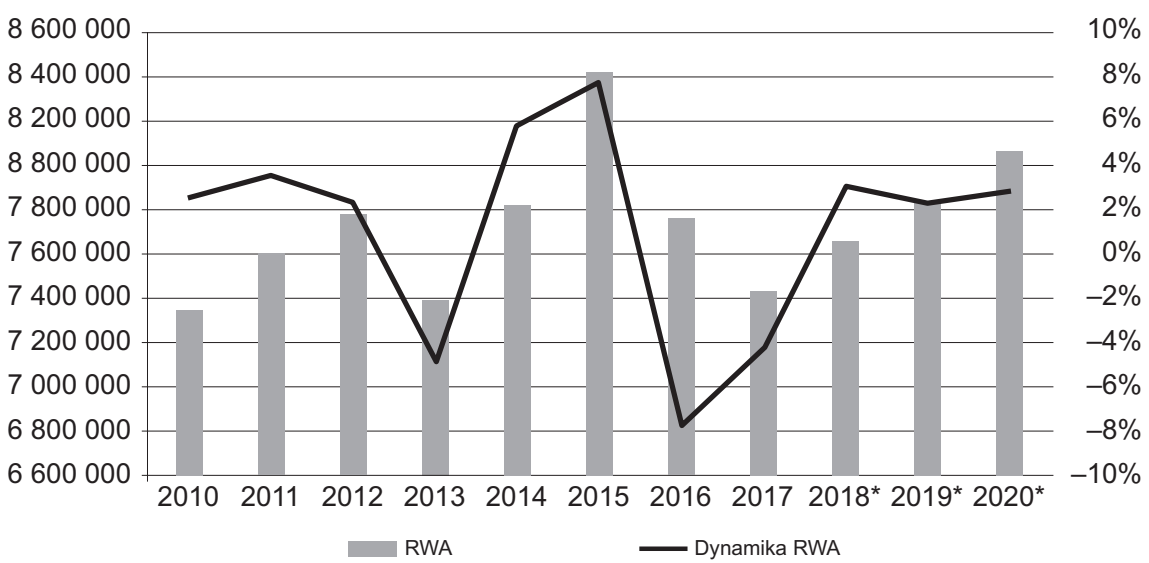

Źródło: opracowanie własne; dane DB Research, European Banks. Report, March 19, 2018.

np. z 5 do 2 lat, część z banków utrzymuje na pokrycie niektórych aktywów tylko 1/8 kapitału obliczanego przez inne banki. Jak widać czynnik administracyjny może mieć więc wpływ na zmianę struktury portfela. Bezpośrednim skutkiem może stać się racjonowanie kredytu w celu zmniejszania dźwigni w działalności banków. Wykres 5 wskazuje nawet na absolutny spadek RWA

7 Obliczenia DB Research, Basel eyes set periods for banks' models 19. DBnetwork, Feb. 19, 2013. 
(Risk-Weighted Assets, aktywa ważone ryzykiem) banków UE, a nawet ujemną dynamikę RWA w ostatnim okresie - mimo stosunkowo dobrej koniunktury, co jest efektem słabego wzrostu kredytu oraz dążeniem do zmniejszenia ryzyka portfeli, a także dostosowania zaawansowanych metod wewnętrznych modeli ratingowych IRB.

Skutki kolejnych regulacji przeprowadzonych $\mathrm{w}$ ramach ostatniej fazy Bazylei III analitycy szacują na około $90 \mathrm{mld}$ EUR, wbrew politycznym deklaracjom o neutralności ich wpływu na wymogi kapitałowe ${ }^{8}$ (BS.NET. Internetowy Serwis Bankowości Spółdzielczej, 2018). Wymóg dotyczący modeli IRB, według oczekiwań regulatorów, musi stanowić co najmniej 72,5\% obliczonego metodą standardową, IRB bowiem, zdaniem regulatorów, pomaga bankom zaniżać wymogi kapitałowe. Wymogi CET1 dla banków z Europy muszą wynosić 11,6\%, a dla G-SIB - 10,9\% (EU Commission Consultation Document Exploratory Consultation on the Finalisation of Basel III) ${ }^{9}$. Group of Governors and Heads of Supervision zaaprobowało pakiet poprawek do ram Bazylei - co ma stanowić zakończenie reformy Bazylei III:

1. Rewizja metody standardowej dla ryzyka kredytowego (SA-CR) w kierunku wzrostu skali i wrażliwości na ryzyko kredytowe.

2. Rewizja IRB dla ryzyka kredytowego, aby zmniejszyć zmienność w kalkulacjach banków RWA.

3. Minimalny haircut (zabezpieczenie jako procent wartości aktywów) na nieclearowane centralnie papiery wartościowe finansujące (STF) w celu ograniczenia procykliczności - ogranicznie lewaru dla systemu finansowego.

4. Naprawa CVA - usunięcie modelu wewnętrznego IMA i wprowadzenie rozwiązań bazowych (BA-CVA) i rewizja podejścia standardowego (SA-CVA), aby zwiększyć wrażliwość na ryzyko i spójność.

5. Nowy standard na ryzyko operacyjne (SA-OR) zastępujący istniejący standard i podejście zaawansowane do ryzyka w celu uproszczenia ram i wzrostu porównywalności.

6. Zastąpienie Basel II floor (bufor lewaru dla G-SIB) agregatowym wskaźnikiem bardziej wrażliwym na ryzyko, aby wdrożyć limit na korzyści z regulacyjnego kapitału wynikające z modeli wewnętrznych dopuszczonych przez Bazyleę II.

8 Komunikat G20 Baden-Baden 17-18 March 2017: Support for the Basel Committee on Banking Supervision to finalise the Basel III Framework Without Further Significantly Increasing Overall Capital Requirments Across the Banking Sector.

9 EU Commission Consultation Document Exploratory Consultation on the Finalisation of Basel III). 7.12.2017. 
Ad 1. Ma na celu wzmocnić due dilligence w bankach i doprowadzenie, aby wagi ryzyka (RW) były właściwe i ostrożne. Szczególnie dla ekspozycji nieratingowanych. Dla ratingowanych ekspozycji wobec banków nastąpi rekalibracja wag ryzyka - szczególnie dla covered bonds. Dla korporacji stworzone będą nowe tabele wag ryzyka specjalnie dla MŚP. Nowe kategoria ekspozycji to: finansowanie obiektowe oraz commodities finance. Nowe miary dla kredytów mieszkaniowych mają być bardziej wrażliwe na ryzyko i zależne LTV, a nie tylko na kategorię kredytu. Podobnie zostaną wprowadzone nowe wrażliwe miary na ryzyko dla commercial real estate. Nowe miary zostana też wdrożone dla pożyczek detalicznych - większa granulacja. Dla pozycji pozabilansowych miary będą bardziej wrażliwe na ryzyko - miara credit conversion factors (CCF) oraz wprowadzony zostanie pozytywny CCF dla unconditionaly cancellable commitments. Będzie też dokonana dalsza rekalibracja dla transakcji z zabezpieczeniami (collateral).

Ad. 2. Modele wyceny IRB mają być prostsze i mniej wrażliwe na zmiany struktury aktywów. Opcja A-IRB ma być usunięta dla niektórych klas aktywów - kredyty dla korporacji, MŚP oraz instytucji finansowych. Banki będą mogły używać fundation IRB (F-IRB). IRB nie będzie mogła być stosowana przy ekspozycjach na kapitały własne innych podmiotów - equity. Będą minimalne poziomy (floors) na PD dla F-IRB oraz A-IRB, a także LGD i EAD - rekalibracja parametrów.

Ad. 3. Bazylea III w 2011 roku wprowadziła wymóg kapitałowy na ryzyko mark to market instrumentów pochodnych - pogorszenie się ryzyka kontrahenta - counterparty (CVA). Zamiarem regulatorów jest usunięcie wszystkich modeli zaawansowanych do wyceny ryzyka i zastąpienie ich metodą standardową lub bazową (basic approach). Metoda standardowa będzie budowała modele na miarach wrażliwości, a metoda bazowa na bieżącej metodzie standardowej dla CVA. Dla tych, których ekspozycja na derywaty jest $<100 \mathrm{mld}$ (poza CCP) wymogi kapitałowe będą prostym mnożnikiem ryzyka kredytowego kontrahenta (counterparty).

Ad. 4. Tu ma nastąpić największa rewizja, ponieważ spełnienie się ryzyka było znacznie wyższe niż alokowany kapitał według wcześniejszych metod. Metody zaawansowane i standardowe będą zastąpione przez single risk-sensitive standardised approach (SA-OR). W efekcie ma też nastąpić zmiana definicji dochodu brutto (gross-income).

Ad. 5. Ograniczenie dla modeli IRB do $72,5 \%$ kalkulacji RWA z metody standardowej.

Jak widać uruchomienie jednej regulacji implikuje wdrażanie całego ciągu dalszych regulacji - coraz bardziej szczegółowych i bardziej skomplikowa- 
nych. W opinii wielu analityków mniejsze banki nie podołają tym wymogom i zostaną odcięte od wielu segmentów rynków finansowych. W takich sytuacjach wielkie banki uzyskają jeszcze większą przewagę konkurencyjną, ograniczając biznes banków małych i średnich do najprostszych i najmniej dochodowych produktów i usług bankowych.

Planowane od 2016 roku i częściowo wdrażane zmiany w ramach Bazylei 3,5 oraz ciągle dyskutowanej Bazylei IV spowodują kolejne zmiany w kapitałach banków. Deklarowanym celem jest wyeliminowanie dowolności i ujednolicenie kryteriów wyceny ryzyka i kapitałów. Planowane na lata 2018-2020 zmiany standardowych wag ryzyka, standardowych modeli ryzyka operacyjnego, kredytowego dla dużych korporacji i instytucji finansowych i CVA wywołują duże niezadowolenie banków z Europy. Dyskutowane wprowadzenie Bazylei IV zmieni wartość aktywów ważonych ryzykiem (RWA) między 18 a 30\%, co przełoży się na potrzebę wzrostu kapitału między 210 a 410 mld euro tylko dla banków europejskich. W sytuacji, gdy zwrot na kapitale powinien wynosić przynajmniej ok. 8\%, a lepiej, żeby było to blizej $10 \%$, to od 210 mld euro rocznie będzie on kosztował banki kapitał własny. Tymczasem marża kredytowa skorygowana o ryzyko w UE spadała z ponad 3\% w 1987 do około 2,25\%, w roku 2017. Rezerwy na ryzyko ze względu na proces derisking kształtują się na poziomie niskim - obecnie około 0,6\%. W dniu 16 czerwca 2017 roku odbyło się posiedzenie Rady do Spraw Gospodarczych i Finansowych (ECOFIN), w trakcie którego Rada potwierdziła swoje stanowisko w zakresie „szybkiej ścieżki” (fast track) zatwierdzenia niektórych pozycji pakietu CRDV/CRR2, w tym dotyczących MSSF 9, dużych zaangażowań i hierarchii kredytowej. Zamiana IAS39 na IFRS9, bazuje na oczekiwanej stracie (EL), wcześniejszym uznaniu strat na kredytach, zmianie prawdopodobieństwa niewypłacalności PD i oraz potencjalnych stratach - w przypadku bankructwa (LGD). Kolejnym efektem wdrożenia MSSF 9 jest wzrost odpisów na oczekiwaną stratę kredytową, a w konsekwencji nagłe obniżenie regulacyjnych współczynników kapitałowych. Przepisy w tym zakresie (MSSF 9) zaczęły obowiązywać od 1 stycznia 2018 roku.

Skutkiem takiej polityki regulacyjnej oraz dramatycznego wzrostu kosztów, a także braku wiary inwestorów w perspektywę rozwoju branży jest niski zwrot na kapitale obecnie 6,4\% (wykres 6). W 2017 roku 20 największych banków UE zmniejszyło przychody o $2 \%$, w tym prowizje o $3 \%{ }^{10}$.

10 Deutsche Bank Research, Fitness programme continues July 112018 . 
Ale jednocześnie odpisy na rezerwy na kredyty stracone spadły o $20 \%$, co poprawiło zyskowność o $4 \%$. Mimo poprawy, taki jednak poziom nie gwarantuje chęci inwestorów do zakupu akcji banków i ogranicza de facto dostęp do rynku kapitałowego. Poziom zwrotu na kapitale daleko odbiega od tego, który wynikałby z teorii CAPM (Lock i in., 2018).

Wykres 6. Zwrot na kapitale w bankach UE

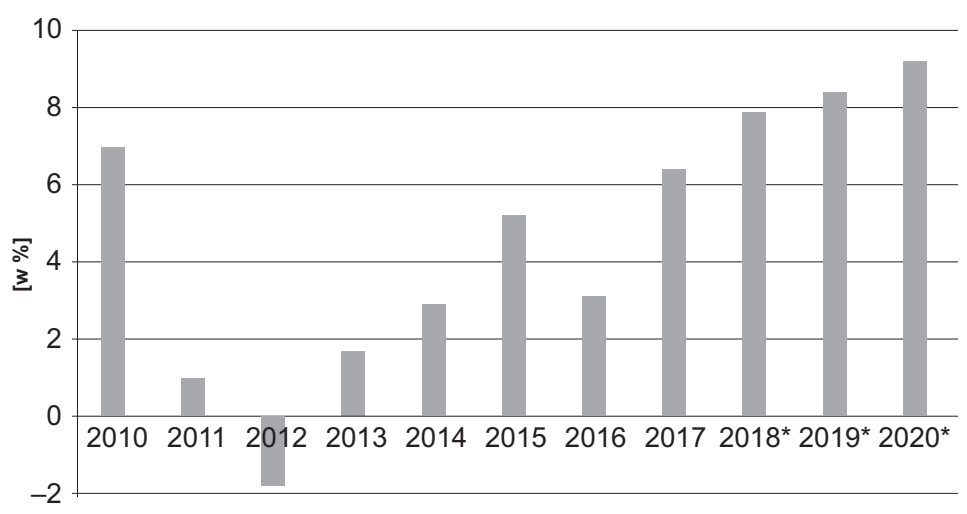

Źródło: jak wykresu 5.

Dwa kolejne wskaźniki - P/E i P/B niezbicie potwierdzają niską dochodowość sektora bankowego, brak perspektyw rozwojowych, a ich rynkowa wartość kapitału kształtuje się poniżej wartości księgowej $(0,95)$ (wykresy 7 i 8).

Wykres 7. P/E dla banków UE

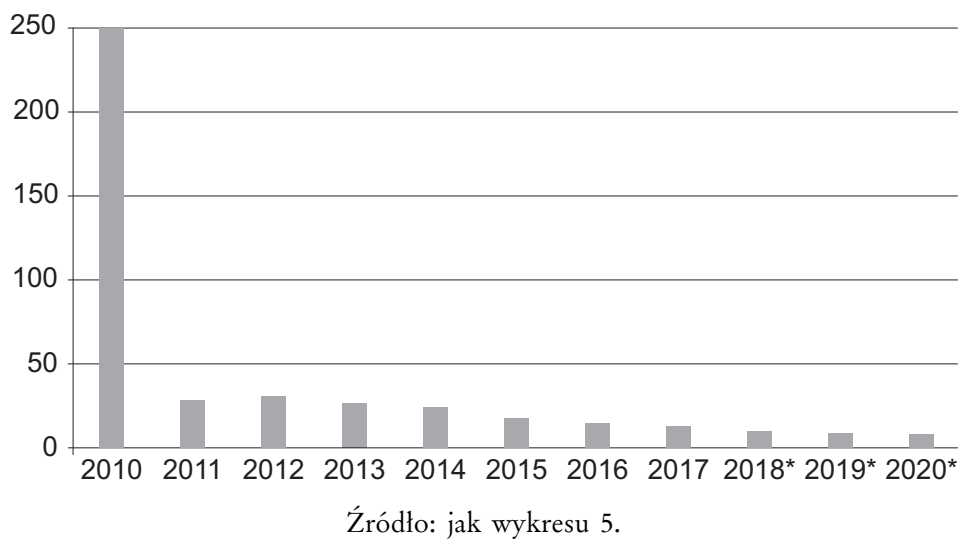




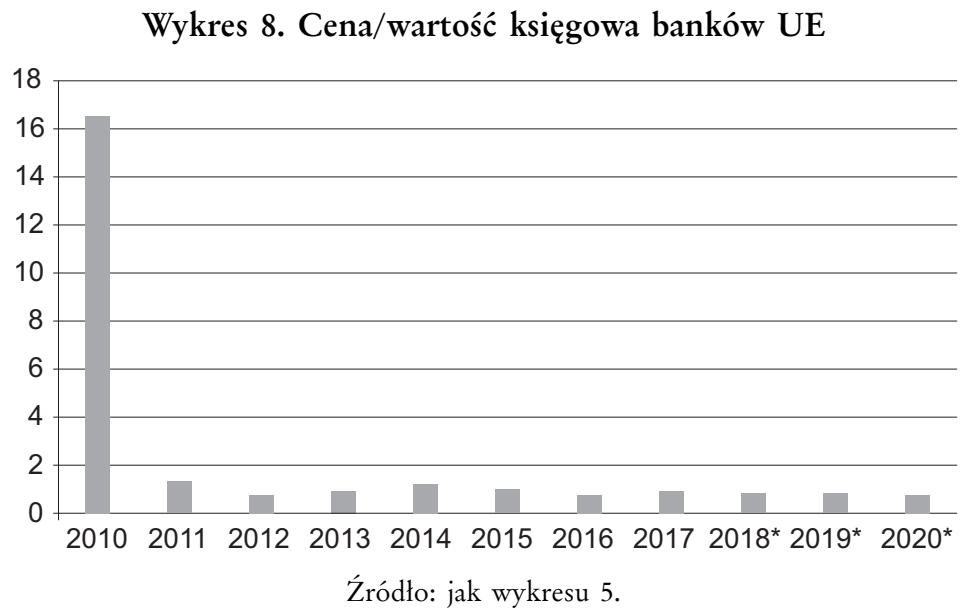

W efekcie sektor bankowy sygnalizuje utratę wrażliwości na ryzyko i prowadzi do niewłaściwej dyslokacji aktywów ważonych ryzykiem (RWA). Efektem kolejnej fali regulacji jest/będzie wzrost kosztów kapitału. Europie grozi wzrost CT1 o 250 bps, a RWA o 20\% (100 bps na ryzyko kredytowe, 80 bps na operacyjne, 20 bps na ryzyko rynkowe i 40 pbs na IFRS-9). W przypadku niektórych banków europejskich nowa wycena aktywów ważonych ryzykiem może wzrosnąć nawet o 50\% - włączając efekt IFRS-9. W przypadku Japonii szacowany wzrost RWA wyniesie tylko $10 \%$, ale RWA dla akcji w holdingach ze $120-160 \%$ wzrośnie do $250 \%$. Tylko w przypadku banków z USA zmiana wyceny RWA będzie bliska 0\%. Taki rozmiar popytu na kapitał jest równowartością 3-letnich zysków. To grozi stabilności finansowej banków i brakiem perspektyw wzrostu finansowania kredytem. Szacowana wartość współczynnika CT1 z obecnej wartości $12,5 \%$ spadnie do ok. $10 \%$ - 1 p.p. Credit RWA, $-0,2$ p.p. Market RWA, $-0,8$ p.p. operacyjne RWA, capital -0,1 p.p., IFRS-9 $-0,4$ p.p. Mało kto uświadamia sobie, że obok wpływu na kapitał taka polityka powoduje dodatkowy podatek nakładany na sektor bankowy, chociaż deklaracje polityczne podkreślały stabilizację obciążeń podatkowych - read my lips no new taxes. Jak widać inwestorzy $\mathrm{w}$ to nie wierzą i banki są sprzedawane na giełdach przy $0,81 * \mathrm{P} / \mathrm{B} 9,6 \% \mathrm{P} / \mathrm{E}$ oraz ROE $8,6 \%$. Historycznie od 1880 roku RoE w sektorze bankowym kształtowało się między 10 a 15\% ${ }^{11}$. Dzieje się tak mimo deklaracji Lorda Hilla - europejskiego komisarza do spraw Stabilności finansowej (financial stability is a prerequisite for growth). I want to be more proportionate - more ambitious about reducing reporting and disclosure require-

11 Autonomus Research. 
ment ${ }^{12}$. Na wykresie 9 można zauważyć, że obciążenie wszystkimi podatkami łącznie w UE kształtuje się na poziomie około $25 \%$.

Ocenia się, że dodatkowo Bazylea IV zmieni wartość aktywów ważonych ryzykiem od $18-30 \%$, co się przełoży na potrzebę wzrostu kapitału od 210-410 mld EUR, czyli koszt roczny od 21-41 mld EUR. Brak konsekwencji $\mathrm{w}$ regulowaniu i zachodzące zmiany powodują, że środki zainwestowane w modele IRB-A zostaną w dużej mierze utracone - w 2021 roku 55\% banków ma mieć standardowy model, a w 2025 roku - 75\%.

Wykres 9. Obciążenie podatkowe banków UE

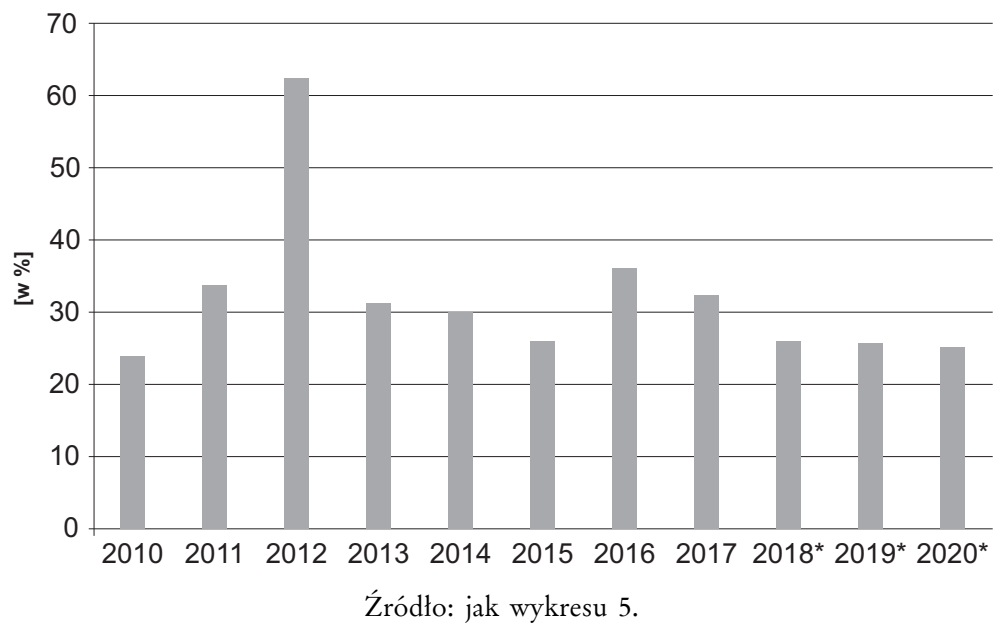

Dodatkowo na banki spoza USA (działające w USA) nakładane są nowe wymogi kapitałowe - kolidujące z regulacjami europejskimi ${ }^{13}$. W rezultacie, banki spoza USA będą musiały wpompować miliardy dolarów w swoje filie w USA lub ograniczyć działalność na terenie Stanów Zjednoczonych. Opublikowana Notice of Propsed Rulemaking FED nakazuje bankom zagranicznym o aktywach ponad 50 mld USD utrzymywanie lokalnie kapitałów na poziomie banków amerykańskich. Już takie banki, jak Deutsche Bank i Barcklays przesuwają dużą część bankowości inwestycyjnej do innych podmiotów prawnych. W 2012 r. Komitet Bazylejski szacował, że 102 największe banki międzynarodowe potrzebują jeszcze 374 mld EUR, aby spełnić

\footnotetext{
12 Jonathan Hill EU Commissioner for Financial Stability, Financial and Capital Market Union.

13 Daniel Tarullo z FED obowiązek banków zagranicznych zgodnie z Dodd-Frank Act - kolizje z regulacjami europejskimi.
} 
wymagania kapitałowe, co oznaczało spadek luki kapitałowej w stosunku do 2011 roku o 111 mld EUR. ECOFIN przewiduje, że systematycznie ważne instytucje finansowe (SIFI) będą musiały podwyższyć współczynniki wypłacalności od 1 do 3\%, a lokalni nadzorcy dla tych instytucji moga wymagać współczynników kapitałowych nawet o 5 punktów procentowych wyższych. Jak pokazuje wykres, banki UE w ciągu 7 lat podniosły kapitały o 363 mld euro i oczekuje się dalszego ich wzrostu. Szczególnie duża dynamika wzrostu kapitałów dotyczyła lat wdrażania Bazylei III - gdzie dochodziła nawet do $15 \%$ (wykres 10 ).

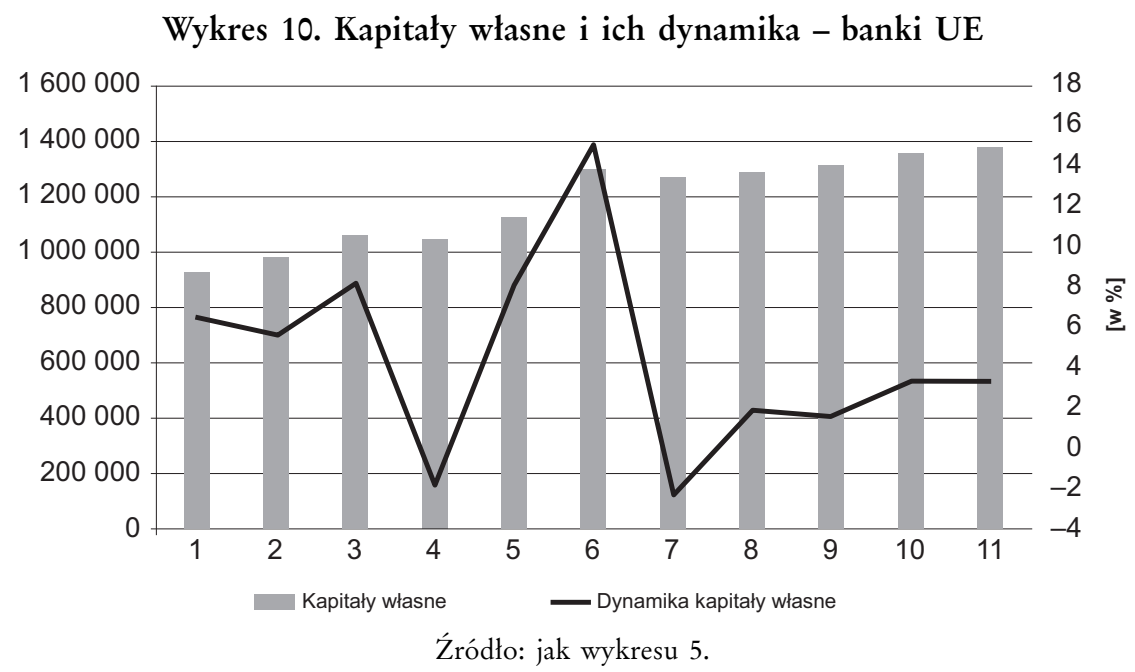

Analizując wykres 11 można zauważyć, że wysiłek akumulacji kapitału w bankach UE doprowadził do wzrostu współczynnika CT1 z 11,4 do 15,6\%, co wskazuje na rosnące bezpieczeństwo sektora bankowego.

Jeszcze w 2010 roku wskaźnik kosztów do dochodów C/I ratio w 20 największych bankach europejskich ledwo przekraczał $56 \%$, a obecnie jest to blisko $70 \%$ - W. Brytania 86\%, Włochy $78 \%$, Niemcy 74\%, Francja $68 \%$ (Moody's, 2017, s. 5). Wiele banków USA i z UE poniosło narzucone przez nadzorców gigantyczne kary, co oczywiście ma uzasadnienie, ale skala obciążeń zdecydowanie wpłynęła na sytuację sektora. Kwota kar zbliża się obecnie do 300 mld \$, gdzie Bank of America zapłacił 80 mld \$; JP Morgan $38 \mathrm{mld}$ \$; Lloyds $21 \mathrm{mld} \$$, a wiele innych banków od kilku do kilkunastu mld \$. Celem tych kar jest w USA finansowanie ulgi dla konsumentów (44,5 mld \$) oraz instytucji, takich jak Fannie \& Freddi (39 mld \$). 


\section{Wykres 11. Współczynnik CT1 banków UE}

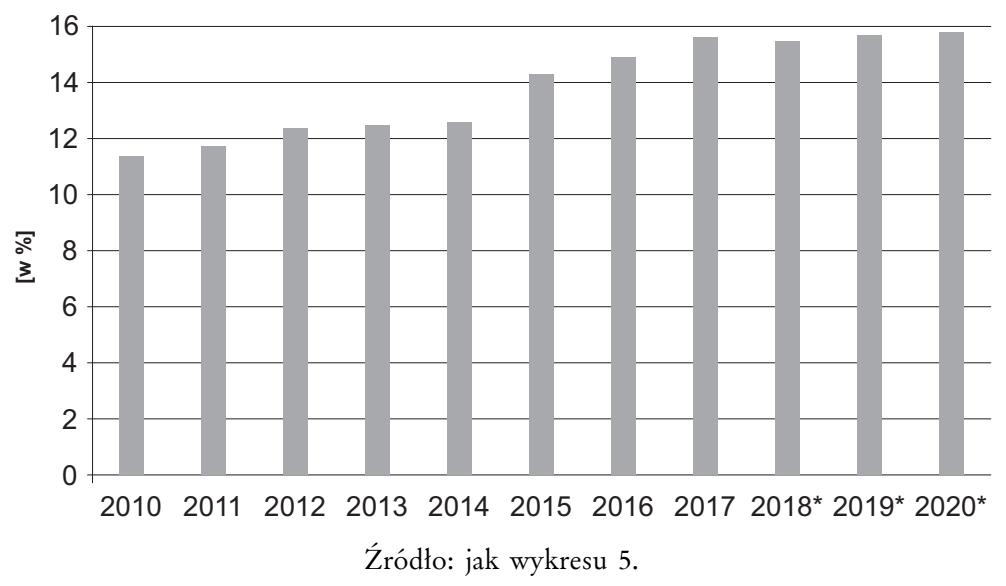

\section{Analiza stanu polskiego sektora bankowego}

Wydaje się, że sytuacja polskich banków nie przedstawia się dobrze. Kredyt rośnie stosunkowo wolno - wolniej niż depozyty (wykres 12).

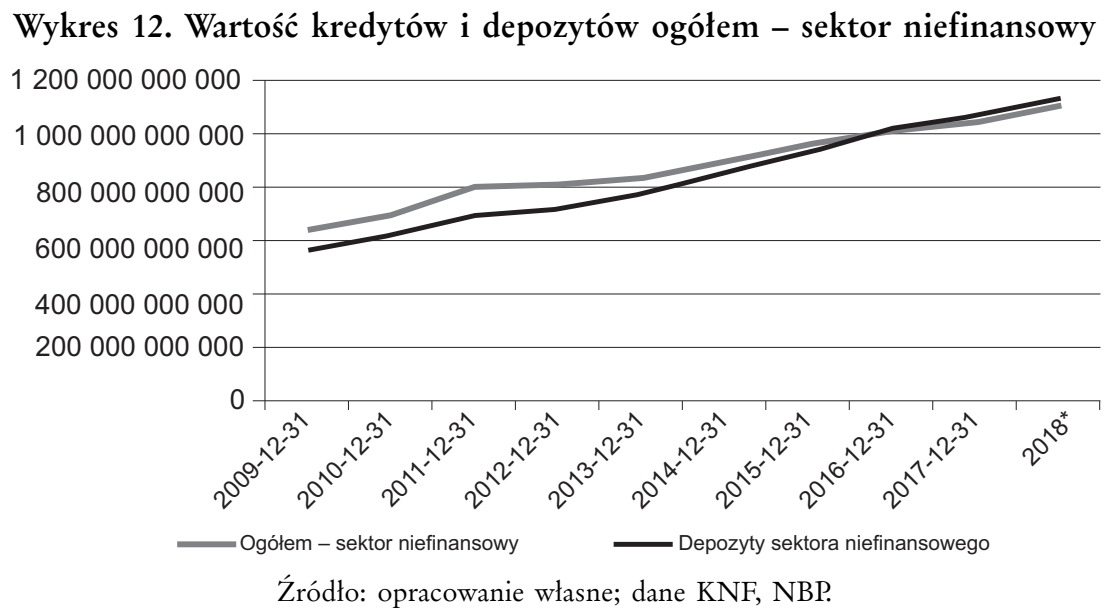

Wydaje się, że po 3 latach spadku dynamiki kredytów i depozytów można będzie oczekiwać wzrostu aktywności gospodarczej, a także przyrostu oszczędności oraz że ujemne realne stopy procentowe nie będą skłaniać do nadmiernych oszczędności (wykres 13). 
Wykres 13. Dynamika kredytu i depozytów ogółem - sektor niefinansowy

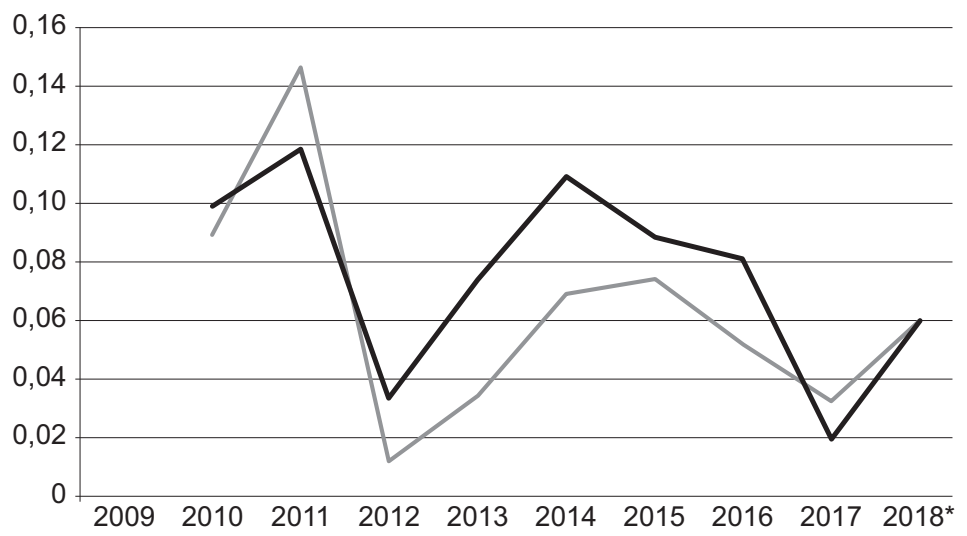

-Kredyt ogółem Depozyty instytucji niefinansowych ogółem

Źródło: opracowanie własne; dane NBP.

Wykres 14. Dynamika kredytu dla gospodarstw domowych

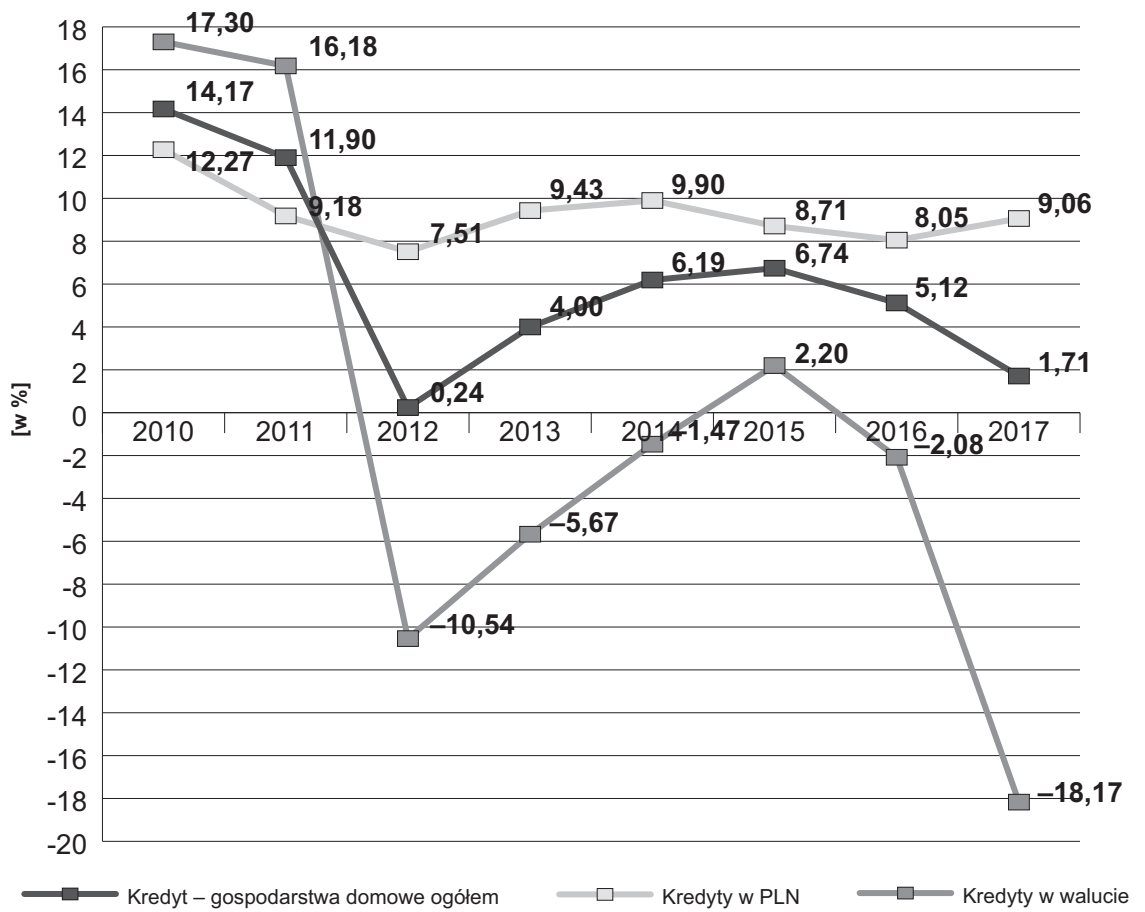

Źródło: jak wykresu 12. 
Należy zauważyć, że dynamika kredytu ogółem dla ludności w 2017 roku osiągnęła historyczne minima - na co składały się dwa czynniki - spłaty kredytów walutowych oraz lekka aprecjacja złotego do CHF w 2017 roku. Słabo także rósł kredyt złotowy - częściowo w wyniku zaostrzenia kryteriów, ale również ze względu na niewielki wzrost popytu ${ }^{14}$ (por. wykres 14).

Nieco lepiej rozwijała się dynamika kredytu dla przedsiębiorstw - szczególnie w odniesieniu do kredytów w złotych, ale przy spadku kredytowania walutowego - netto kredyt rósł poniżej nominalnego wzrostu PKB (wykres 15).

\section{Wykres 15. Dynamika kredytu dla przedsiębiorstw}

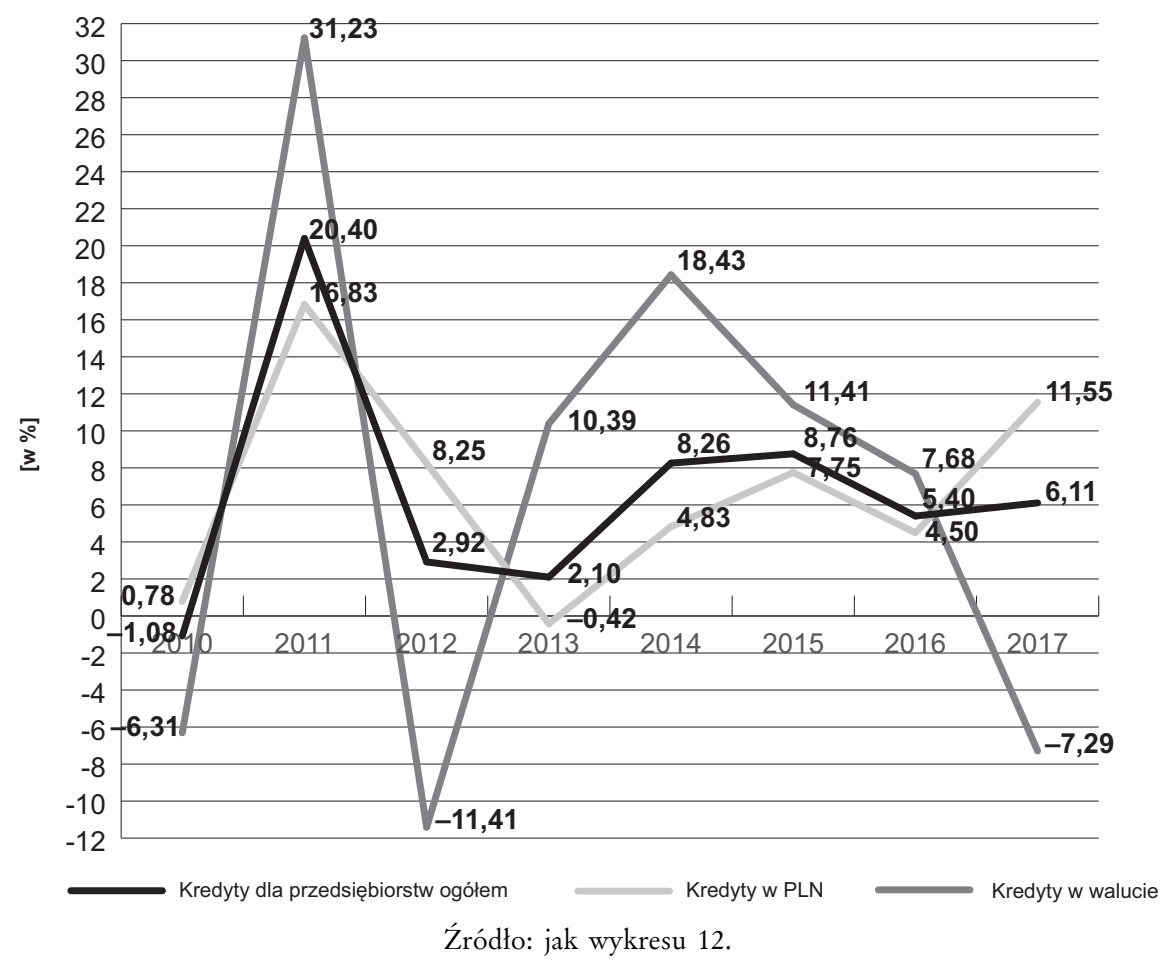

Interesujący jest spadek dynamiki depozytów podmiotów krajowych. O ile bowiem spadek depozytów terminowych, przy niskich stopach procentowych, jest zrozumiały, o tyle spadek dynamiki depozytów a vista może sygnalizować niedobór płynności i problemy płatnicze przedsiębiorstw (wykres 16).

14 ZBP Sektor bankowy w Polsce uwarunkowania rozwoju, Warszawa 11.06.2018. 


\section{Wykres 16. Dynamika depozytów}

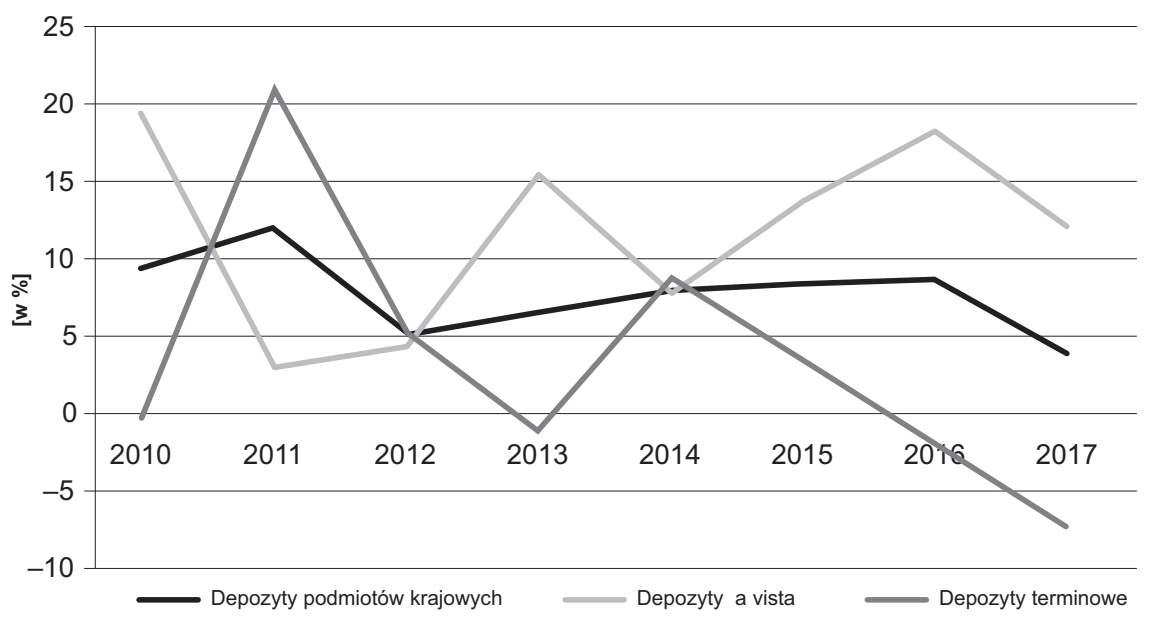

Źródło: jak wykresu 12.

Intrygujący jest wysoki wzrost, w przypadku depozytów a vista, dynamiki depozytów w walutach i spadek dynamiki depozytów w PLN, co może wskazywać na element spekulacyjny i zabezpieczenia wartości zasobów pieniężnych $\mathrm{w}$ walucie, co z kolei mogłoby świadczyć o oczekiwaniach inflacyjnych i deprecjacyjnych (wykres 17).

Wykres 17. Dynamika depozytów a vista

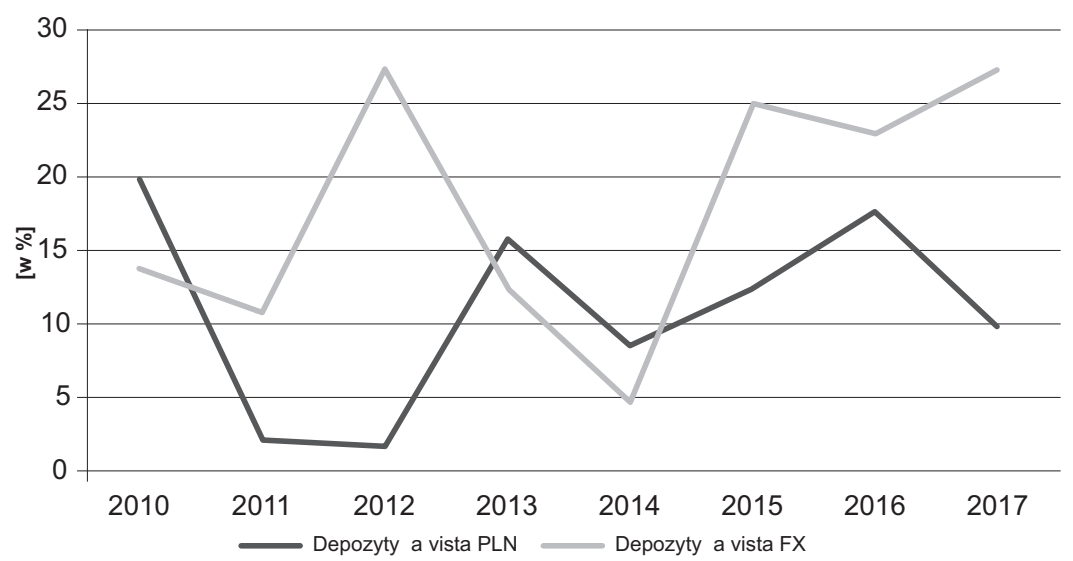

Źródło: jak wykresu 12. 
Silny spadek dynamiki depozytów terminowych w PLN i w walucie może być skutkiem niskich stóp procentowych i spadku realnej wartości oszczędności pieniężnych. Malejący popyt na pieniądz w formie depozytów terminowych może oznaczać malejące zaufanie w odniesieniu do pieniądza i skłonność do przechowywania wartości w innych aktywach finansowych (wykres 18).

Szczególnie niepokojąca jest malejąca dynamika oszczędności w postaci depozytów bankowych w stosunku do rosnącej dynamiki PKB. Mogłoby to wskazywać na przenoszenie konsumpcji z nadchodzących lat na dzień obecny - wysoka skłonność do konsumpcji kosztem oszczędności (wykres 19).

Wykres 18. Dynamika depozytów terminowych

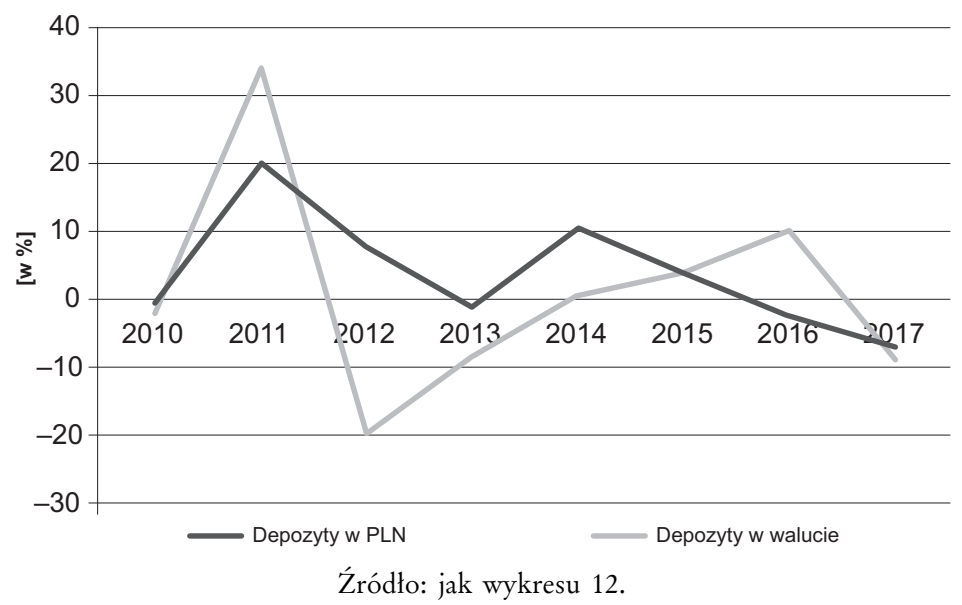

Wykres 19. Dynamika depozytów oraz nominalnego PKB

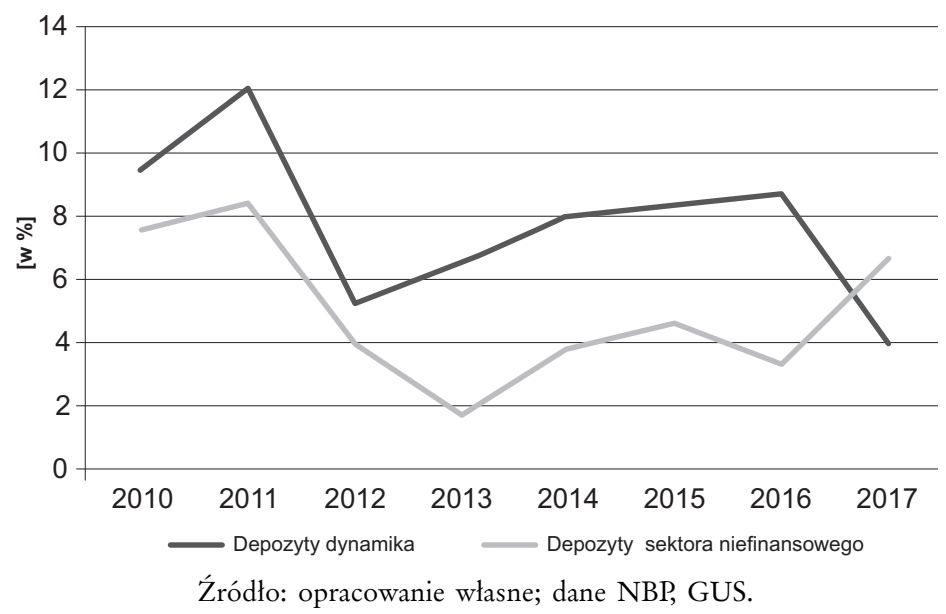


Znaczące spowolnienie dynamiki kredytu w stosunku do nominalnego wzrostu PKB w ostatnich latach może wskazywać na potencjalną możliwość pojawiania się w gospodarce wąskich gardeł w zakresie płynności (wykres 20). Warto w tym względzie przeanalizować czy rosnące wymogi kapitałowe nie stanowią bariery dla dalszego finansowania gospodarki narodowej przez sektor bankowy.

Wykres 20. Dynamika kredytów i nominalnego PKB

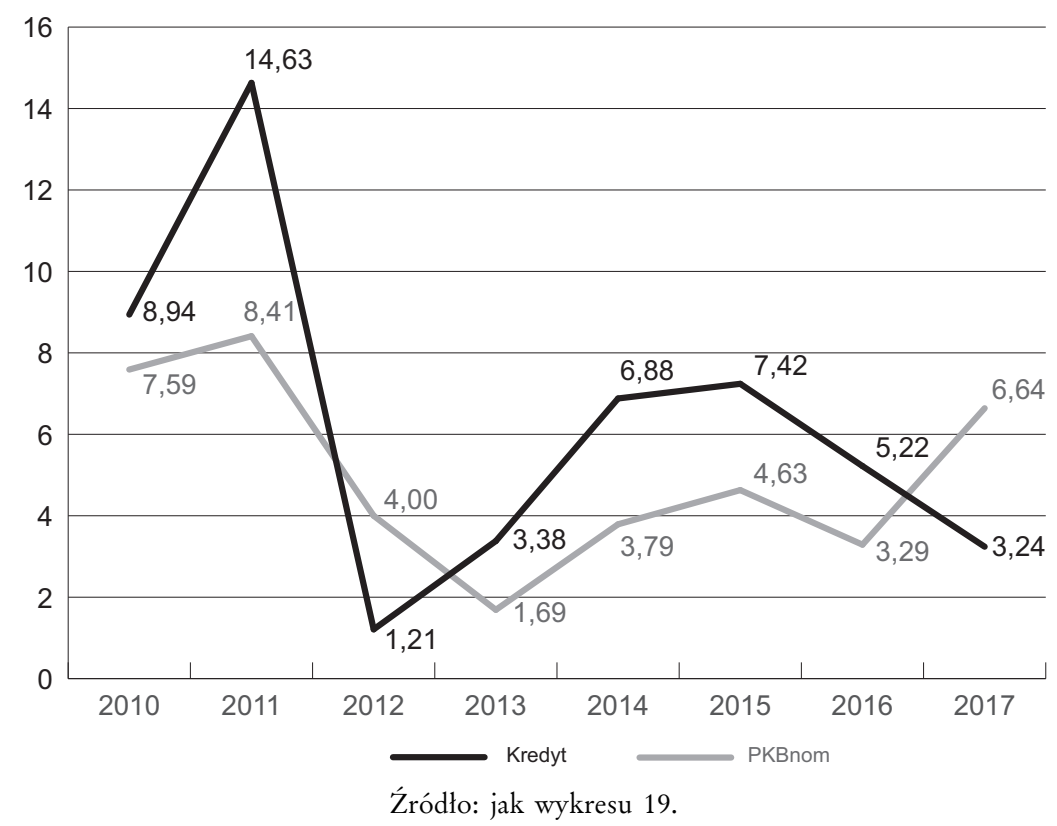

Znaczące zaniepokojenie może budzić spadek relacji nominalnej wartości kredytu dla gospodarki w stosunku do PKB (wykres 20). Tę obserwację potwierdza wykres 21. Za szybszym wzrostem PKB w 2017 roku nie podążył wzrost kredytowania. Gdyby ta tendencja miała się utrzymać, zachodzi pytanie o przyczyny - czy kwestie regulacyjne i kosztowe nie przekładają się na pojawianie się $\mathrm{w}$ polskim sektorze bariery kapitałowej, z powodu podatku od instytucji finansowych, rosnących marż i kosztów kredytu dla krajowych przedsiębiorstw.

Może zaniepokoić sytuacja, w której zarówno depozyty ludności per capita, jak i aktywa całego systemu bankowego per capita rosną wraz ze wzrostem $\mathrm{PKB} /$ capita znacznie wolniej niż w poprzednich latach (wykres 21 i 22). Tym bardziej, że w innych krajach dynamika wzrostu aktywów sektora bankowego i depozytów ludności per capita rośnie szybciej niż w Polsce. 
Wykres 21. PKB/capita a aktywa banków/capita

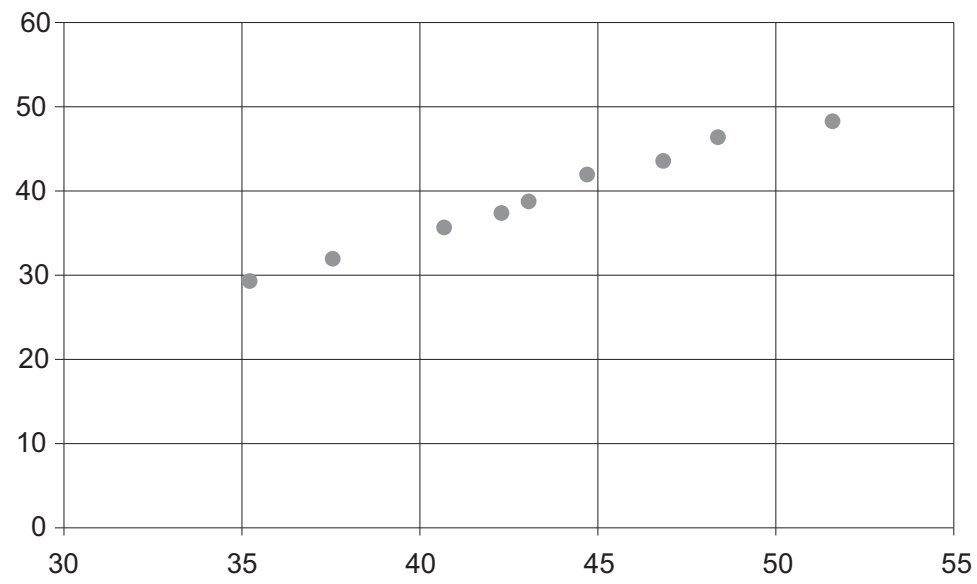

Źródło: opracowanie własne; dane KNF, NBP, GUS.

Wykres 22. Kredyt nominalny PKB

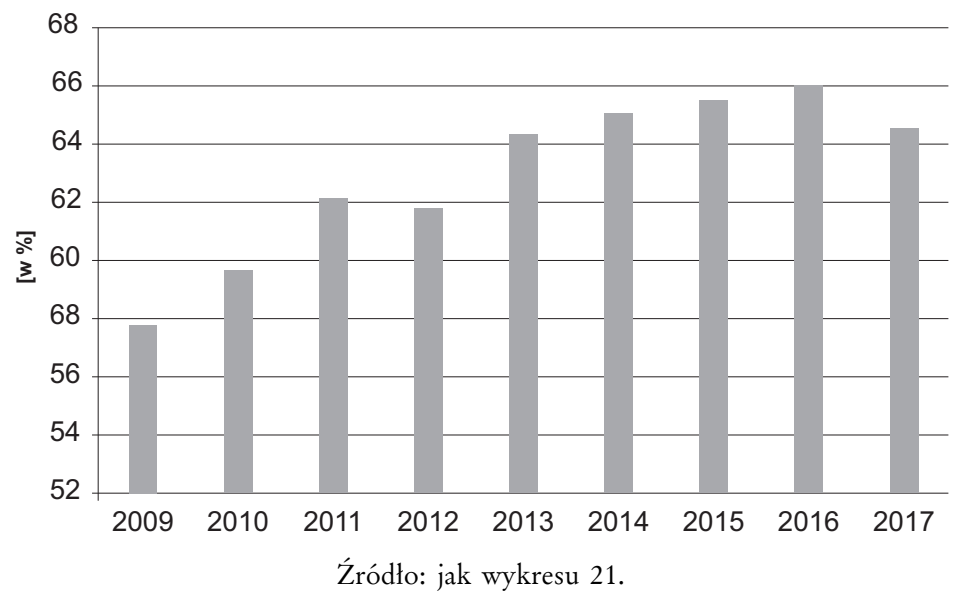

Wykres 23 wskazuje natomiast na spadającą rentowność kapitału w sektorze bankowym. Zysk do funduszy własnych jest na historycznie najniższym poziomie - istotnie niższym niż w innych krajach UE. Ten poziom zwrotu na kapitale $\mathrm{w}$ sektorze bankowym tworzy zagrożenie dla pozyskiwania nowego kapitału własnego do banków, bez którego ze względów regulacyjnych i ekonomicznych mogą powstawać bariery w finansowaniu krajowym gospodarki - zwiększając popyt na kredyty zagraniczne. 
Wykres 23. Zysk/fundusze własne

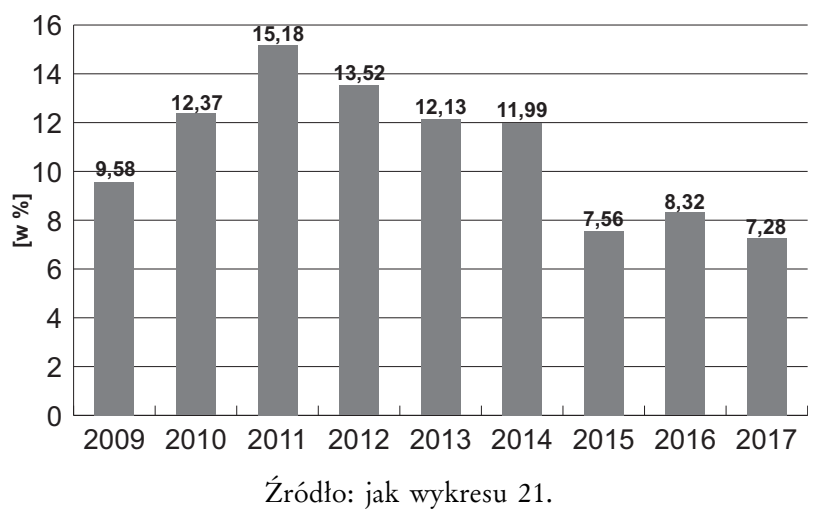

Kolejny wykres 24 wskazuje na rosnący udział odsetek w stosunku do prowizji w przychodach banków. Może to być efektem kompensowania sobie przez banki rosnących kosztów podatku od podmiotów finansowych oraz kosztów BFG. Oznacza to wzrost marży bankowej między relatywnie niżej oprocentowanymi depozytami a rosnącymi ze względu na podatek kosztami kredytu.

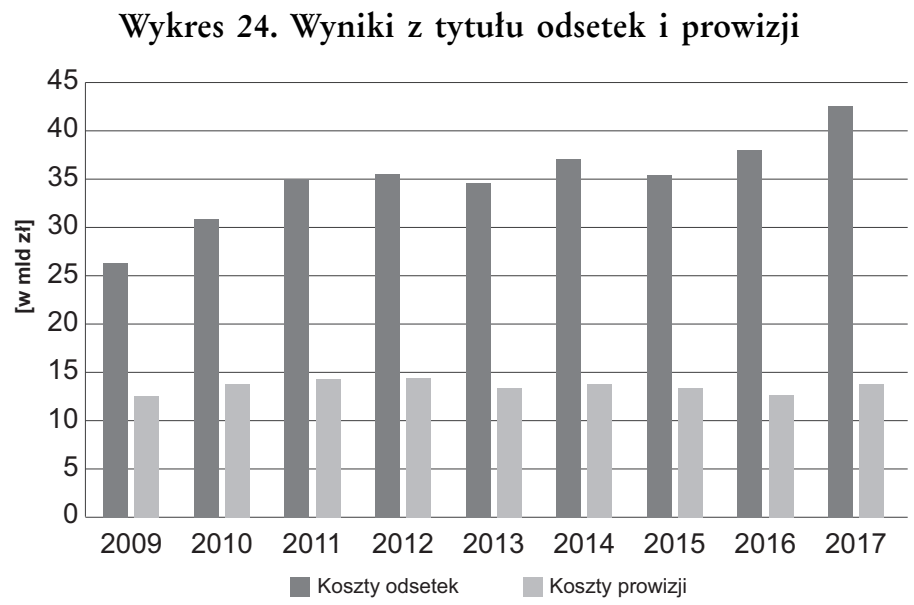

Źródło: opracowanie własne; dane KNF.

Wydaje się też, że wykres 25, pokazujący koszty banku w stosunku do kosztów ogólnego zarządu, doskonale odzwierciedla dramatyczny przyrost kosztów regulacyjnych i publicznych od 2013 roku. Koszty ogólnego zarządu (w tym podatki, obciążenia na BFG, inne koszty regulacyjne) zrównały się 
z kosztami działania banków. Polska jest również krajem obciążonym masowo kosztami zarówno ze względu na regulacje, jak i obciążenia publiczne. Dochodzi do paradoksów, takich jak podatek bankowy naliczany od rezerwy na podatek bankowy lub obciążanie banków podatkiem dochodowym naliczanym od kosztu wpłat na BFG oraz podatkiem dochodowym od podatku bankowego. Tylko podatek bankowy (podatek od aktywów) szacowany jest na 3,4 mld zł, a BFG na 2,3 mld PLN. Dodatkowo banki wpłaciły na fundusz wsparcia pożyczkobiorców $800 \mathrm{mln}$. Nie można też pominąć ponoszonych przez sektor kosztów usług, które decyzją państwa są świadczone nieodpłatnie. Obciążenia sektora z różnych tytułów przekraczają 7 mld PLN.

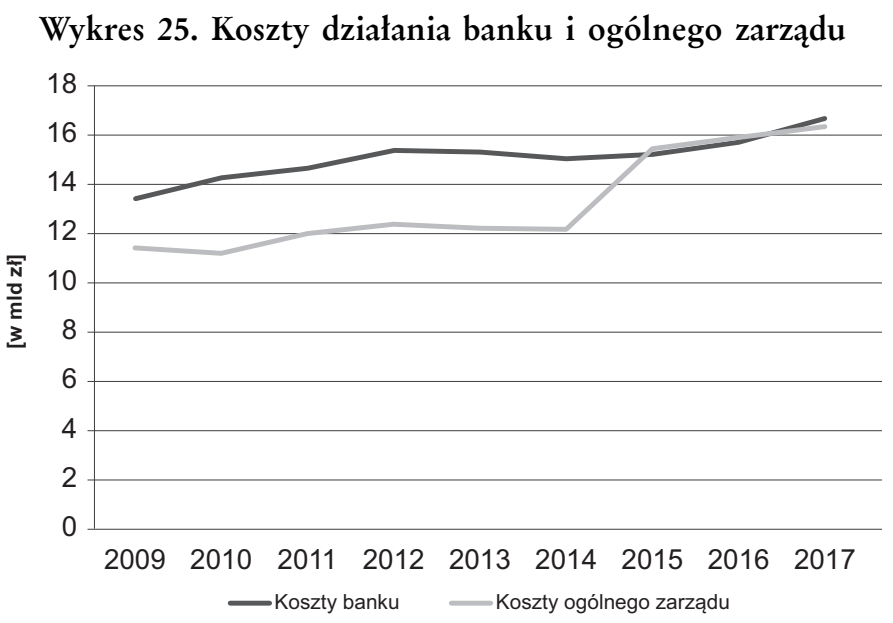

Źródło: opracowanie własne; dane KNF.

Dynamika kosztów w latach 2014-2016 (szczyt wdrożeń regulacyjnych w Polsce) okazała się istotnie wysoka (wykres 26). Implikacją tego stanu jest konieczność redukcji kosztów ogólnego zarządzania - redukcje nakładów na analizy makroekonomiczne, obniżenie serwisu informacyjnego dla klientów, redukcja wydatków reklamowych, sponsoringowych itp. Wstępne analizy wskazują, że banki będą musiały zredukować koszty od 5-10\%15. Są jednak i opinie, że banki będą musiały zredukować koszty operacyjne od 20-45\%, a swoje bilanse zmniejszyć o nawet 50\%16. Skutkiem ograniczeń nakładanych na banki jest również rosnąca fala zwolnień w sektorze bankowym. Innym

15 DB, Basel eyes set periods for banks' models 19. DBnetwork, 19 February 2013.

16 Insight B., How Europe's Banks Can Return to Health, free report: Top 10 Stocks 2013. 
działaniem może być przebudowa - z punktu widzenia ryzyka - portfela należności i przesunięcie finansowania w kierunku instytucji publicznych, instytucji finansowych i firm o wysokich ratingach kredytowych. Ubocznym efektem może być dalsze ograniczenie finansowania przedsiębiorstw o ratingach $\mathrm{B}+$ do B-, których to firm jest wiele w Polsce.

Wykres 26. Dynamika kosztów działania banków i ogólnego zarządu

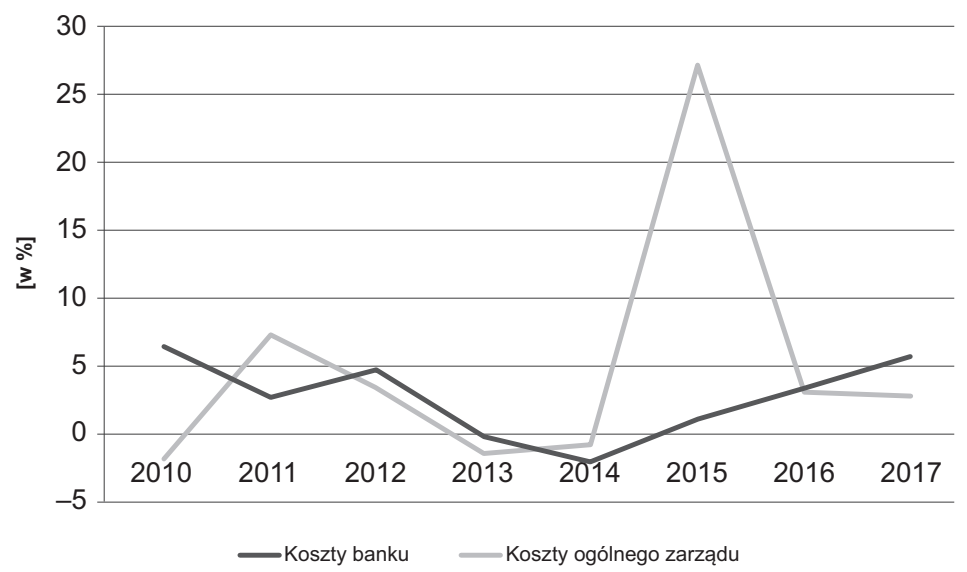

Źródło: jak wykresu 25.

Wysokie regulacyjne wymogi kapitałowe w stosunku do skali kredytów i ich ryzyka implikowały w sposób oczywisty dalszy wzrost kosztów i podatków ponoszonych przez sektor bankowy (wykres 27). Równocześnie w Polsce dodatkowy problem polega na tym, że współczynniki pokrycia kapitałami aktywów ważonych ryzykiem nie są porównywalne z obowiązującymi w innych krajach. Dotyczy to wag ryzyka przeliczających wymóg kapitałowy, które w Polsce są wyższe niż w EU. Na przykład w wielu krajach kredyty hipoteczne mają wagę ryzyka $35 \%$, podczas gdy u nas złotowe kredyty hipoteczne mają wagę od 35 do $75 \%$, a walutowe $100 \%$, na kredyty walutowe wprowadzono zaś wagę ryzyka nawet $150 \%$. W ten sposób ekwiwalentem naszego współczynnika wypłacalności około 17\% jest równowartość 24-26\% w innych krajach Europy. W ostatnim czasie wzrost kapitałów wzrósł dodatkowo - zgodnie z wymaganiami unijnymi - dyrektywą CRD IV o $12 \mathrm{mld}$ zł (bufor zabezpieczający (Tier1)). Dodatkowe wymagania KNF dotyczące domiaru kapitałowego wymaganego przez KNF od 14 banków zaangażowanych w kredyty mieszkaniowe w CHF podwyższyły potrzeby kapitałowe o kolejne $10 \mathrm{mld}$ zł. 


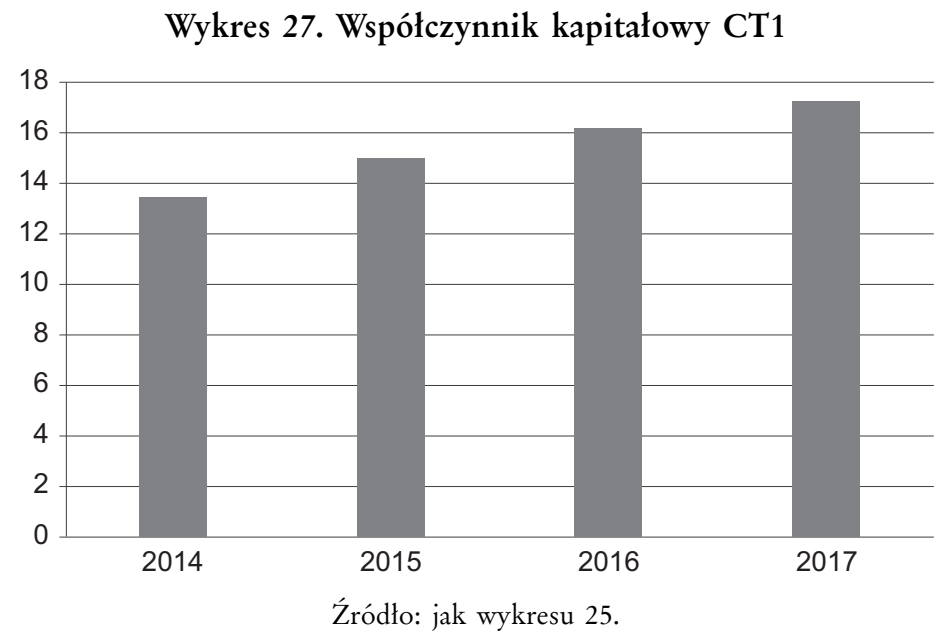

Ceną za poprawę relacji funduszy własnych do kredytu - czyli obniżania lewaru - jest oczywiście spadek rentowności sektora bankowego (wykres 28).

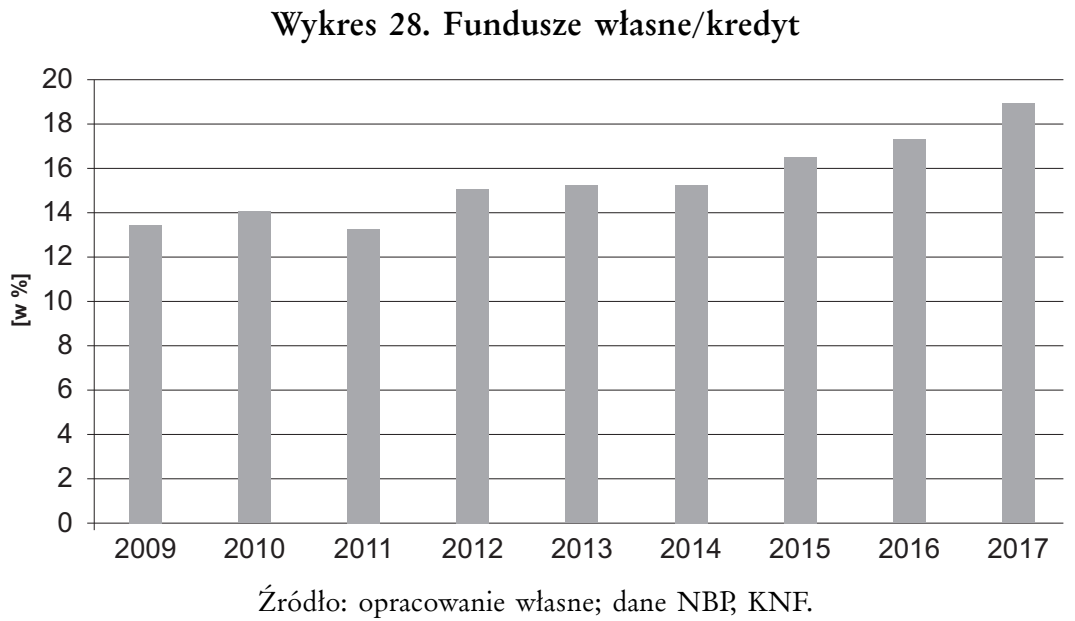

Skutkiem wzrostu obciążeń daninami publicznymi oraz kosztów regulacyjnych wyraźnie maleje dynamika zysku sektora bankowego. Byłaby ona również istotnie mniejsza w roku 2016, ale nadzwyczajne przychody z odkupu akcji VISA zakłóciły na jeden rok ten trend (wykres 29). 
Wykres 29. Dynamika zysku

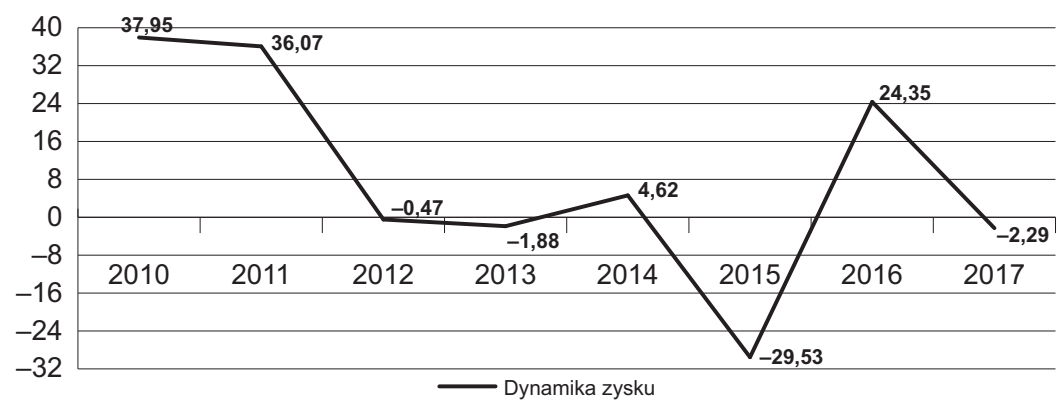

Źródło: jak wykresu 25.

Trend spadkowy zwrotu z funduszy własnych banków datuje się już od 2011 roku (wykres 30), ale skala spadku rentowności jest w ostatnich latach wyjątkowo wysoka - groźna dla dalszego rozwoju sektora i potrzeb finansowania gospodarki. A przecież wymogi regulacyjne jeszcze się nie zakończyły, czeka nas jeszcze regulacja MREL, która będzie wymagać dodatkowo ponad 50 mld złotych finansowania funduszami podporządkowanymi - wysoce kosztownymi. Drenowanie sektora bankowego z kapitału staje się niebezpieczne w sensie systemowym.

Wykres 30. Zysk/średni poziom funduszy własnych

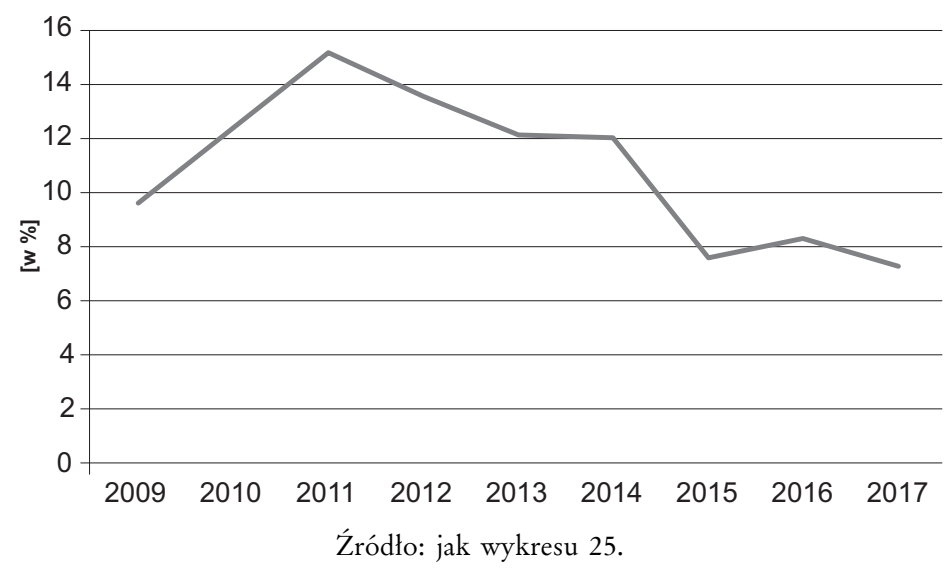

Spadek rentowności kapitałów (ze względu na obciążenia publiczne) następuje $\mathrm{w}$ fazie dobrej koniunktury i wyraźnego spadku należności przeterminowanych (wykres 31). 


\section{Wykres 31. Należności przeterminowane/kredyt dla gospodarki}

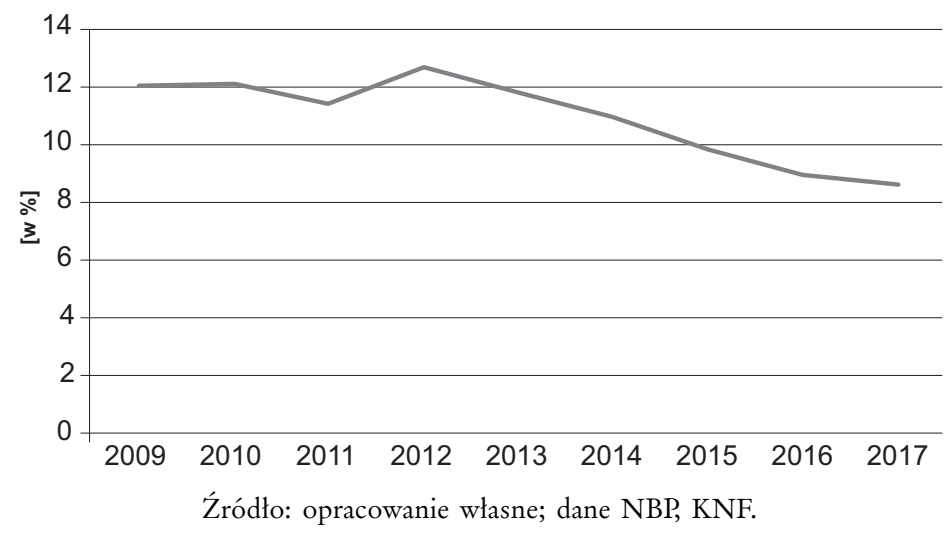

Dotychczasowe analizy wskazują na negatywny wpływ obciążen kapitałowych na wzrost gospodarczy. Tabela 1 podsumowuje wrażliwość spowolnienia PKB na każdy 1\% wzrostu współczynnika kapitałowego, co w przypadku Polski przelicza się na utratę wielu miliardów PKB rocznie.

Tabela 1. Wzrost obciążeń kapitałowych vs spowolnienie PKB

\begin{tabular}{|c|c|}
\hline Współczynnik kapitałowy (w \%) & Koszty (\% PKB) \\
\hline 7 & 0,00 \\
\hline 8 & 0,05 \\
\hline 9 & 0,10 \\
\hline 10 & 0,16 \\
\hline 11 & 0,21 \\
\hline 12 & 0,26 \\
\hline 13 & 0,31 \\
\hline 14 & 0,36 \\
\hline 15 & 0,41 \\
\hline 16 & 0,47 \\
\hline 17 & 0,52 \\
\hline 18 & 0,57 \\
\hline 19 & 0,62 \\
\hline
\end{tabular}

Źródło: Kalicki i Antczak, 2014.

Spadek zatrudnienia w sektorze bankowym jest już wyraźnie widoczny na wykresie 32. 
Wykres 32. Zatrudnienie w sektorze bankowym

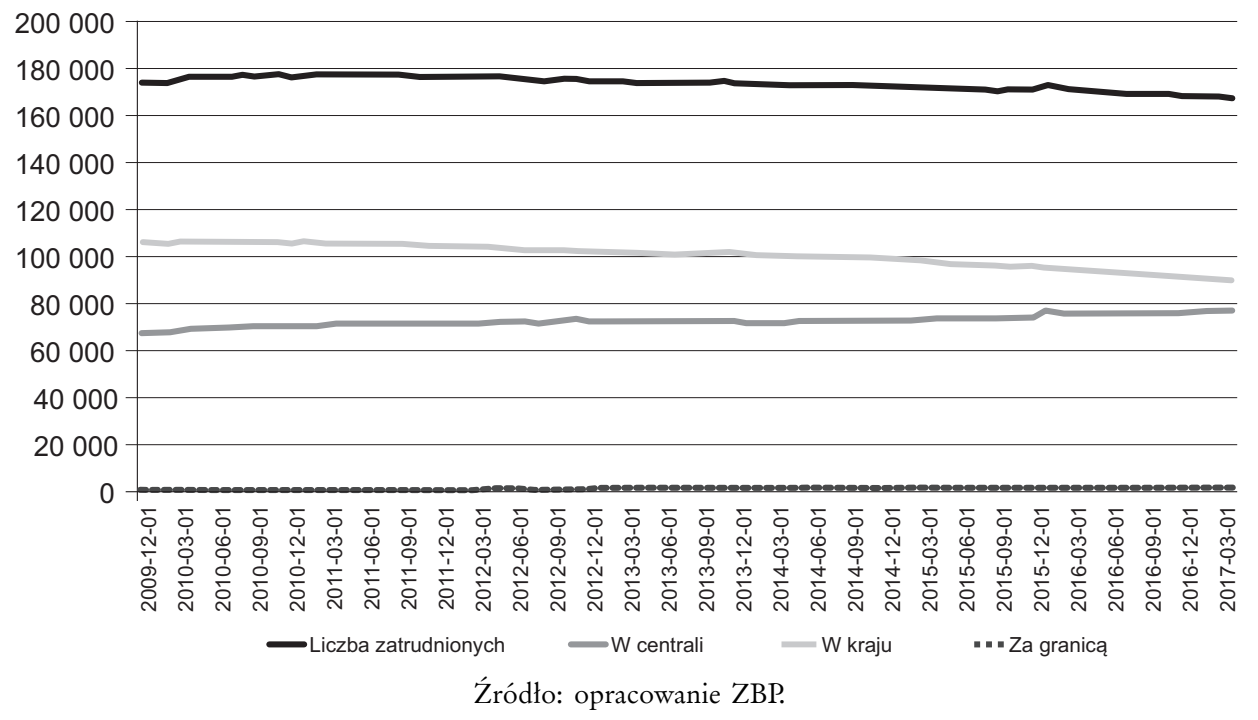

Wykres 33. Wybrane wskaźniki dla banków z przedstawionych krajów

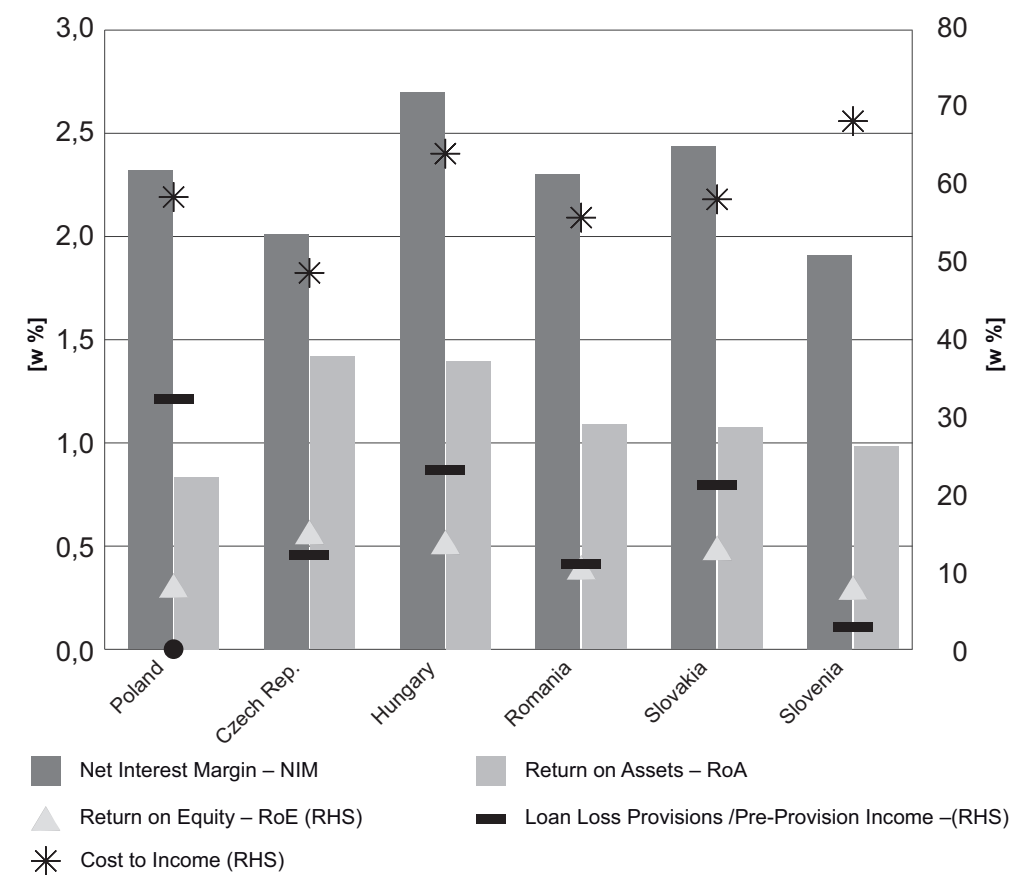

Źródło: Prezentacja Moody’s Investors Service 2017 (Central Banks/Regulators). 
Obciążenia kosztami publicznymi w Polsce są $\mathrm{w}$ pełni widoczne na tle sytuacji banków w krach Europy Wschodniej będącymi członkami UE (wykres 33). Przy podobnej skali marży odsetkowej (net interest margin) zwrot na aktywach i na kapitale jest w Polsce najniższy. Implikacją tego stanu jest wychodzenie wielu zagranicznych banków dobrze zakorzenionych banków z Polski, co w długim okresie będzie prowadzić do oligopolizacji rynku bankowego ze wszystkimi tego negatywnymi skutkami.

\section{Podsumowanie}

W środowiskach finansowych słychać wyraźne głosy protestu. Jacques de Larosiere ${ }^{17}$ ostro oponuje przeciw nadmiarowi regulacji w sektorze bankowym, wskazując, że prowadzi to do ograniczenia funkcji pośrednika kredytowego przez banki, a stosowanie tych samych regulacji dla wszystkich rodzajów banków nie wydaje się być racjonalne. Ponadto prawodawcy wprowadzają wiele regulacji, które obciążają banki dodatkowymi podatkami i opłatami oraz kosztami zwiększonych wymogów informacyjnych lub organizacyjnych, powodując dalsze pogarszanie się perspektyw dochodowych banków i zniechęcając inwestorów od nabywania akcji banków. Czynią to zarówno politycy z Europy, jak i ze Stanów Zjednoczonych, wciągając gospodarkę w kleszcze kolejnego credit crunch.

Wśród pracowników nauki opinie w tej sprawie nie są jednoznaczne. Profesorowie, jak David Miles z Banku Anglii, uważają, że to za mało kapitał banków powinien wynosić od 16 do 20\%. Innego zdania jest profesor Tim Congdon który uznaje, że 7\% CAD już oznacza przeregulowanie sektora bankowego. Brak jest jakiegokolwiek uzasadnienia teoretycznego pozwalającego odnieść się do kryteriów, skali kosztów i skali biurokracji związanych z tymi procesami. Prof. S. Hanke podkreśla, że wiele przepisów utrudnia rozwój gospodarki USA ${ }^{18}$. Nawet Financial Stability Board opublikował list Chairmana Marka Carney'a do G-20 oceniający reformy postkryzysowe i wskazujący ramy oceny postimplemetacyjnej skutków łącznie z niezamierzonymi skutkami reform. SEC Chairman, Jay Clayton, wskazał, że w licznych przypadkach efekty regulacji nie są spójne z oczekiwaniami. To jest kosztowna praktyka wychodząca za „ostrożne zarządzanie”

17 Przewodniczy grupie ekspertów w UE zajmujących się sprawami nadzoru finansowego.

18 Steve H.Hanke Bank Regulations Continue to Hinder the U.S.Recovery Cato publications, 2.12.2015. 
i architekturę kontroli19. Szefowa FED, J. Yelen, w 2017 roku stwierdzała: „zmiany $\mathrm{w}$ sferze regulacyjnej zasługują na uwagę - takie zmiany powinny dostosowanie do małych i średniej wielkości banków”.

Koszty te ostatecznie obciążają w pierwszej kolejności banki, a ostatecznie de facto całe społeczeństwo, spowalniając w efekcie kredyt dla całej gospodarki i obniżając dynamikę wzrostu gospodarczego. Implikacją walki z kosztami jest dalsza automatyzacja procesów bankowych, restrukturyzacja i redukcja zatrudnienia.

\section{Literatura}

Angelini, P., Clerc, L., Curdia, C., Gambacorta, L., Gerali, A., Locarno, A., Motto, R., Roeger, W., Van den Heuvel, S. i Vlcek, J. (2011). BASEL III: Long-term impact on economic performance and fluctuations. BIS Working Papers, No. 338, February.

Cornillie, J. (2017). Die Bankenunion leidet an dem selben Virus wie die Eurozone. IPG International Politik und Gesellschaft, 24 July.

Hanke, S.H. (2012). Fed Toys with Ratcheting Up the Credit Crunch. Nov. 302012.

Hanke, S.H. (2015). Bank Regulations Continue to Hinder the U.S. Recovery Cato publications. 2.12.2015

Kalicki, K. i Antczak, J. (2014). Impact of BaselII/CRD4 on the Situation in the Banking Sector. W: G.W. Kolodko (ed.), Management and Economic Policy for Development. New York: Nova Science Publishers.

Lock, D., Lakhani, K., Ulargui, I., Sabbione, P., Benhakoun, F., Goy, B., Bergoe, K., Singhal, R. i Hanamante, A. (2018). Banks Monitor: Interest rate sensitivities in a 40 year context, 2 July.

Santos, A.O. i Elliott, D. (2012). Estimating the Cost of Financial Regulation. IMF Staff Discussion Note, SDN12/11. IMF, 11 September.

Slovik, P. i Cournede, B. 92011). Macroeconomic Impact of Basel III. OECD Economics Department Working Papers, No. 844. OECD Publishing, 14 February.

Wehinger, G. (2012). The Financial Industry in the New Regulatory Landscape. OECD Journal Financial Market Trend, 11(2).

BS.NET | Internetowy Serwis Bankowości Spółdzielczej WWW.BS.NET.PL

19 SEC Chairmanship. Jay Clayton My Guide. 12.07.2017. 


\section{JERZY ŻYŻYŃSKI*}

\section{Pieniadz a instytucje finansowe}

Autor analizuje zależność między stanem agregatu pieniężnego a rozwojem rynkowego systemu finansowego. Porównuje relację pieniadza do PKB, poziom oszczędności w stosunku do PKB oraz wielkość kredytu udzielonego w gospodarce w różnych krajach - gtórwnie OECD. Obrazuje, że staby rozwój systemów finansowych w krajach postsocjalistycznych wynika z niskiego stanu agregatu pieniężnego. Pokazuje, że w Polsce byto to skutkiem grattownej utraty agregatu pieniężnego w 1990 r., gdy nie zwaloryzowano oszczędności ulokowanych w bankach.

Słowa kluczowe: pieniądz, agregaty pieniężne, oszczędności, kredyty, instytucje finansowe, transformacja gospodarki.

\section{MONEY AND FINANCIAL INSTITUTIONS}

The author analyzes the relationship between the state of the monetary aggregate and the development of the market financial system. He compares the relation of money to GDP, the level of savings in relation to GDP and the amount of credit granted in the economy in various countries - mainly OECD. He shows that the poor development of financial systems in the post-socialist countries is the result of a low level of financial aggregate. The author shows that in Poland this was the result of a sudden loss of the monetary aggregate in 1990, when the savings deposited in banks were not valorized.

Keywords: money, monetary aggregates, savings, credit, financial institutions, economic transformation.

JEL: E21, E22, E51, G20

Podstawowe znaczenie dla funkcjonowania systemu organizującego przepływy strumieni pieniądza w gospodarce mają instytucje finansowe. Marian Górski trafnie zauważył, że siłą napędową rozwoju gospodarczego jest proces

* Prof. dr hab. Jerzy Żyżyński - Wydział Zarządzania Uniwersytetu Warszawskiego. 
przekształcania oszczędności gospodarstw domowych w inwestycje produkcyjne (Górski, 2009, s. 75) - ale pod warunkiem, że w gospodarce są zorganizowane i sprawnie funkcjonujące instytucje finansowe, które znakomicie opisuje on w swej monografii.

Związek między oszczędnościami a inwestycjami jest od początku istnienia ekonomii jako nauki przedmiotem dyskusji, a nawet ostrych sporów między ekonomistami (Toporowski, 2017). Warto te kwestie metodologicznie uporządkować. Oszczędności to nic innego, jak wynik decyzji podmiotów gospodarczych - zarówno gospodarstw domowych, jak i przedsiębiorców, o niewydawaniu części pozyskanych w formie pieniędzy dochodów (czy szerszej - przychodów). Rozumienie samego pieniądza też jest jednak przedmiotem sporów (Górski, 2009, s. 13-15), bo nie wystarczy twierdzenie, że jego istotą jest pełnienie określonych funkcji ekonomicznych, których listę można znaleźć w każdym podręczniku ekonomicznym. Dla laików, ale też niektórych ekonomistów, kwestia formy wydaje się istotniejsza od funkcji, a w każdym razie uważają oni, że określona forma pieniądza, na przykład postać naturalna, najlepiej w formie kruszcu, jest niezbędna dla skutecznego pełnienia przezeń wszystkich funkcji. Niżej podpisany zaproponował najbardziej syntetyczne ujęcie tych funkcji przez zdefiniowanie pieniądza jako prawa do nabywania tego, co wytworzono w danej gospodarce. Ludzie produkują różne dobra i usługi - miarą ogólnej ich wartości jest PKB - a dla ich rozdzielenia, czyli dystrybucji w społeczeństwie, wynaleziono narzędzie zwane pieniądzem. Daje ono każdemu z członków tej społeczności prawo do nabycia części tych dóbr i usług, stosownie do wkładu, jaki on wniósł - w szerokim rozumieniu - do wytworzenia PKB. Tak więc prawo to otrzymujemy w zamian za to, co sami daliśmy społeczeństwu, przydzieloną każdemu część tych praw nazywamy wynagrodzeniem za pracę lub z tytułu wniesienia wkładu kapitałowego - praca i kapitał są źródłem dochodów. Nabywając dobra i usługi zaspokajające nasze potrzeby, przekazujemy je dalej i w ten sposób prawo to cyrkuluje jako pieniądz w obiegu. Miarą tej jego cyrkulującej ilości jest agregat pieniężny M1. Zaliczamy do niego pieniądz w obiegu oraz sumę tych kwot, które zapisane są na nieoprocentowanych rachunkach bieżących - wykorzystujemy je wszak do dokonywania płatności za zakupy kartą, czekiem czy przelewem.

Część tych praw przenosimy na konta depozytów bankowych. Jest to nazywane oszczędzaniem i stanowi strumień ${ }^{1}$ oderwany od strumienia

1 Warto zawsze podkreślać - bo przez nie ekonomistów ta kwestia często nie jest rozumiana, a wynikają z niej ważne wnioski co do funkcjonowania gospodarki i polityki gospodarczej - że pojęcia ekonomiczne dzielą się na dwie kategorie: strumienie i zasoby. 
dochodów i odłożony $\mathrm{w}$ wyniku rezygnacji z wydawania pieniędzy, czyli wykorzystania części praw do nabycia dóbr i usług w celu zaspokojenia bieżących potrzeb. Oszczędności to zatem, po pierwsze, strumień pieniędzy z dochodów niewydanych na zakupy dóbr i usług, odprowadzony do systemu bankowego. Deponowane na kontach bankowych środki tworzą pasywa banków i stanowią ich zobowiązania wobec klientów². W ten sposób odłożony pieniądz akumuluje się i tworzy tę część zasobu pieniądza, która po dodaniu do M1 tworzy razem z nim agregat M2. W ten sposób agregat pieniężny M2, składa się z dwóch części: pieniądza w obiegu oraz pieniądza zdeponowanego, zakumulowanego. Pieniądz zakumulowany staje się swego rodzaju bazą kapitałową i umożliwia funkcjonowanie innych instytucji systemu finansowego ${ }^{3}$.

Po drugie zatem, oszczędności są zasobem, zgromadzonym w wyniku wieloletniego procesu przekazywania do banków niewykorzystanych na zaspokojenie potrzeb praw do nabywania dóbr i usług. Te odłożone na później są „zawracane” do gospodarki, gdy banki udzielają kredytów lub gdy inne formy kredytowania realizowane są przez niebankowe instytucje finansowe. Środki kierowane do tych instytucji są "wyjmowane” z zasobu odłożonego na depozytach - ma wtedy miejsce zmniejszanie się drugiej, depozytowej części zasobu M2 i ewentualnie zwiększanie ilości pieniądza w obiegu, gdy deponenci przenoszą środki na rachunki bieżące - jednym z czynników skłaniających ich do tego może być niska stopa oprocentowania depozytów bankowych. Środkom kierowanym do instytucji finansowych towarzyszy przepływ w drugą stronę papierów wartościowych potwierdzających prawa wierzycieli - są to przede wszystkim obligacje - instrumenty dłużne (kredytowe) - oraz akcje - instrumenty własnościowe.

Dla sprawnego funkcjonowania i wspierania rozwoju gospodarki zasadnicze znaczenie ma zatem wielkość agregatu pieniężnego, zwłaszcza zawartego w nim zasobu zakumulowanych oszczędności i sposobów oraz kierunków ich wykorzystania. Przyjrzyjmy się podstawowym danym dla grupy krajów, by zobaczyć na ich tle dane dla Polski. W tabeli 1 przedstawiona jest wielkość szerokiego zasobu pieniądza, identyfikowanego z agregatem M3; w przypadku Polski różnica między M2 a M3 jest niewielka - około 10 mld zł.

2 Rolę banków w systemie syntetycznie opisał Górski, 2009, s. 115-202; por. też Kosiński i Nowak, 2011.

3 Niżej podpisany określił je jako „nogę transakcyjną” i „nogę kapitałową” agregatu pieniężnego M2. 


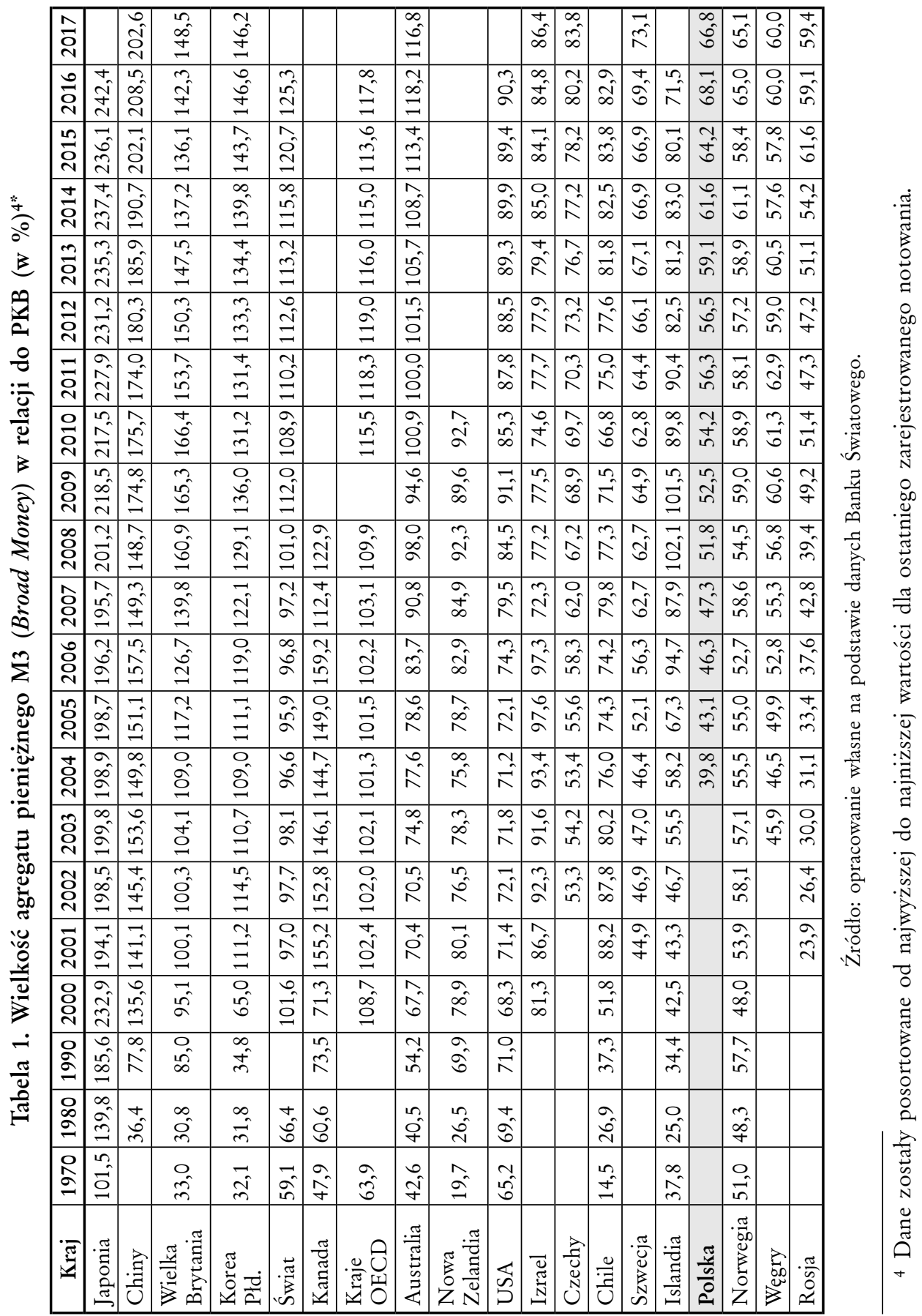


Przez broad money rozumie się gotówkę w obiegu (poza kasami banków); depozyty bieżące i na żądanie (oprócz środków rządu), depozyty walutowe (bez środków rządu), czeki bankowe i podróżne oraz certyfikaty depozytowe i krótkoterminowe instrumenty dłużne (weksle) poza bankami; depozyty na żądanie inne niż depozyty rządu centralnego; czas, oszczędności i depozyty w walutach obcych w sektorach rezydentów innych niż rząd centralny; czeki bankowe i podróżne; oraz inne papiery wartościowe, takie jak certyfikaty depozytowe i papiery komercyjne.

Celem badania było porównanie grupy krajów OECD poszerzonej o kilka ważniejszych krajów spoza tej grupy ${ }^{5}$. Niestety fatalny stan statystyki World Banku, jak również OECD nie pozwala na przeprowadzenie kompletnego porównania, gdyż dla wielu krajów szeregi danych zawierają wiele luk, a dla niektórych krajów w ogóle brakuje danych ${ }^{6}$. Niemniej jednak widzimy, że w Polsce zasób pieniądza w relacji do PKB jest relatywnie bardzo niski, około dwukrotnie niższy niż wynosi norma światowa i dla krajów OECD. W Japonii zasób pieniądza jest prawie 2,5-krotnie wyższy od PKB, w Chinach - dwukrotnie, w krajach rozwiniętych o kilkadziesiąt procent. Widzimy też, że relacja zasobu pieniądza do PKB wykazywała we wszystkich krajach długookresową tendencję wzrostową, była ona jednak bardzo zróżnicowana: od średniorocznego tempa zdecydowanie niższego od $1 \%$ (0,4\% dla Izraela, 0,5\% Norwegii i 0,7\% USA) do kilku procent - przede wszystkim dla krajów przekształcających gospodarki z socjalistycznych na kapitalistyczne $(5,9 \%$ dla Rosji, 4,7\% Chin, 4,1\% dla Polski, ale dla Węgier tylko 1,9\%); dla krajów OECD wskaźnik rocznego tempa wzrost zasobu pieniądza wyniósł 1,3\%, dla krajów o wysokim dochodzie 1,4\%, a dla świata $1,6 \%$.

Nie tempo jest jednak istotne, lecz poziom, źródła tworzenia i kierunki wykorzystania otrzymanych przez podmioty gospodarcze i gospodarstwa

5 Organizacja Współpracy Gospodarczej i Rozwoju (OECD), która powstała w $1961 \mathrm{r}$. obejmuje grupę państw założycieli, do których należą: Austria, Belgia, Dania, Francja, Grecja, Hiszpania, Holandia, Irlandia, Islandia, Kanada, Luksemburg, Niemcy, Norwegia, Portugalia, Stany Zjednoczone, Szwajcaria, Szwecja, Turcja, Wielka Brytania, Włochy; oraz państwa, które przystąpiły po jej utworzeniu: Japonia (1964), Polska (1996), Finlandia (1969), Korea Południowa (1996), Australia (1971), Słowacja (2000), Nowa Zelandia (1973), Chile (2010), Meksyk (1994), Słowenia (2010), Czechy (1995), Izrael (2010), Węgry (1996), Estonia (2010), Łotwa (2016).

${ }^{6}$ Jest znamienne, że brakuje danych dla krajów UE i strefy euro - choć jeszcze kilka lat temu dane te były $w$ tabelach prezentowanych przez tę instytucję. Jest trudne do zrozumienia, dlaczego sowicie opłacani pracownicy WB nie są w stanie zbudować solidnej bazy danych statystycznych dotyczących pieniądza. 
domowe praw do nabywania dóbr i usług, czyli pieniędzy. Przede wszystkim trzeba zauważyć, że środki niewydane przez gospodarstwa domowe i podmioty gospodarcze niekoniecznie muszą być odkładane $\mathrm{w}$ formie zakumulowanych na kontach zasobów depozytowych, które współtworzą szeroki pieniądz ujęty w agregacie M3. Mogą być bezpośrednio lokowane w niepieniężne formy aktywów na przykład na rynkach kapitałowych czy w nieruchomościach, albo za granicą - stąd stosunkowo niski (zdecydowanie poniżej $100 \% \mathrm{w}$ relacji do $\mathrm{PKB}$ ) jest zasób szerokiego pieniądza w krajach wysoko rozwiniętych, takich jak USA, Szwecja czy Izrael. Wyjątkowa jest pozycja Norwegii, która dzięki odkryciu w latach 60. i 70. XX wieku złóż ropy naftowej i gazu ziemnego pod dnem Morza Północnego, została jednym z najbogatszych krajów świata, ale, jak widzimy, wielkość zasobu pieniądza w relacji do PKB jest mniej więcej taka jak w Polsce, a nawet ostatnio nieco niższa. Świadczy to szerokim wykorzystywaniu innych niz pieniądz form lokat oszczędnościowych (podobnie jak w USA). Jest to o tyle ciekawe, że Norwegia jest krajem szczególnym ze względu na wysoką nadwyżkę handlową, sięgającą kilkunastu procent PKB. W latach 2010-2017 średnia wartość bilansu rachunku bieżącego dla Norwegii wynosiła 9,5\% PKB warto zauważyć, że w grupie krajów OECD lepsza była tylko Szwajcaria z wynikiem 10,4\%. Wysokie wartości nadwyżki rachunku bieżącego charakteryzowały tzw. Północ Europy, czyli Holandię (9,1\%), Danię (7,5\%), Niemcy $7,3 \%$, Luksemburg $(5,6 \%)$ i Szwecję (4,9\%).

Wysoka nadwyżka rachunku bieżącego była więc istotnym czynnikiem współtworzącym oszczędności krajowe. W tabeli 2 przedstawiono oszczędności (Gross Domestic Savings) w relacji do PKB, rozumiane strumieniowo jako wynik odjęcia od PKB wydatków konsumpcyjnych. Składają się na ten strumień oszczędności gospodarstw domowych, spółek prywatnych (przedsiębiorstw) i sektora publicznego.

Polska ze stopą oszczędności na poziomie $20 \%$ nie osiąga co prawda wartości średniej ani dla świata (ok. 25\%), ani dla Unii Europejskiej (22,7\%), ani tym bardziej dla strefy euro, która ma wskaźnik nieco wyższy od średniej unijnej $(24,2 \%)$, bliższy średniej dla świata, jest to jednak stopa oszczędności niewiele niższa od krajów OECD (ok. 22\%), ale co warto odnotować, wyższa niż dla takich krajów, jak USA, Kanada czy Wieka Brytania.

Bieżące oszczędzanie nie jest jednak tak istotne jak zasób zakumulowanych środków - który współtworzy agregat M3. Wielkość strumienia oszczędności jest powiązana bezpośrednio z pozostałymi strumieniami makroekonomicznymi: Toporowski w swej monografii (2017, s. 217) za Steindlem przypomina, że zgodnie z keynesowską tożsamością oszczędności $(S)$ stanowią przecież 


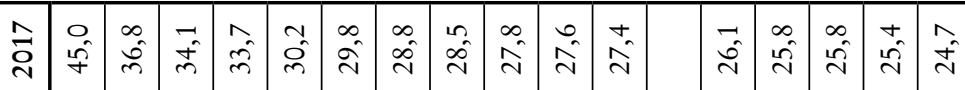

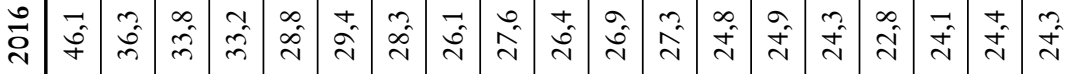

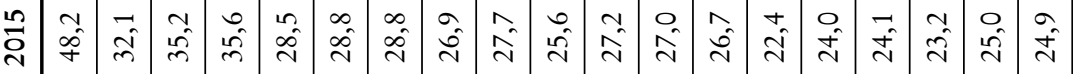

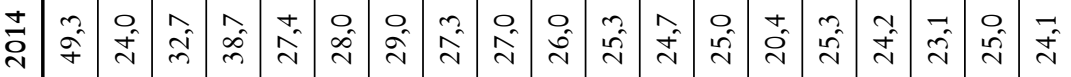

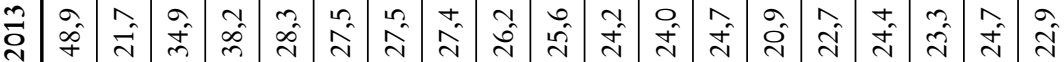

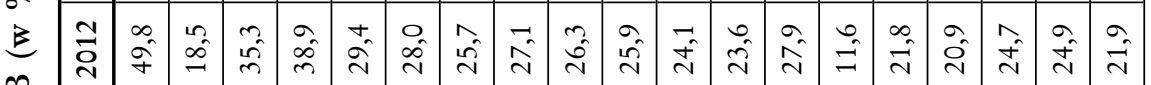

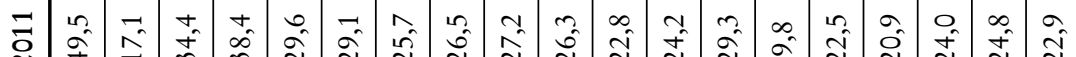

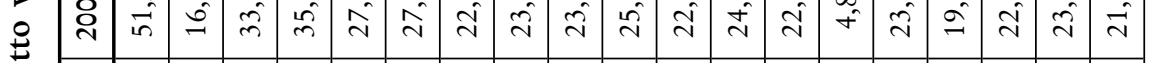

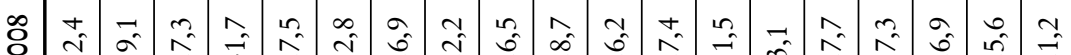

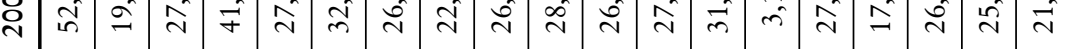

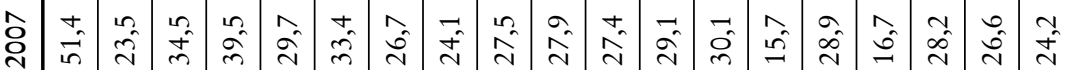

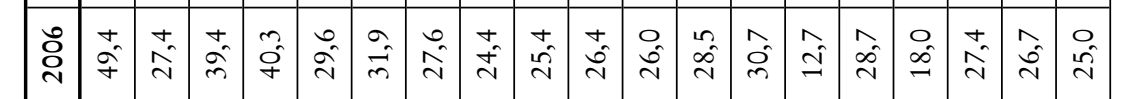

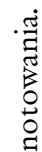
:

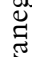
过

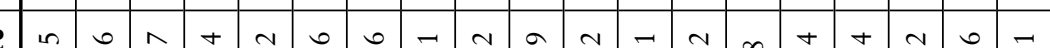

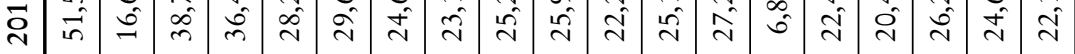

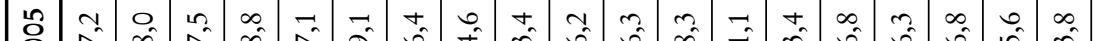

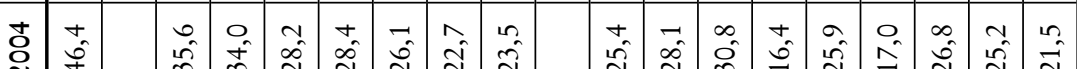

\begin{tabular}{|c|c|c|c|c|c|c|c|c|c|c|c|c|c|c|c|c|c|c|}
\hline$\stackrel{\sim}{f}$ & & $\vec{n}$ & $\left|\begin{array}{c}0 \\
-1 \\
m\end{array}\right|$ & $\stackrel{\sim}{\hat{N}}$ & $\begin{array}{c}\stackrel{n}{n} \\
\infty \\
\sim\end{array}$ & $\begin{array}{l}n \\
2 \\
2\end{array}$ & $\begin{array}{l}0 \\
\hat{v}\end{array}$ & $\overrightarrow{\vec{i}}$ & & $\mid$\begin{tabular}{l}
$\infty$ \\
\multirow{\sim}{\sim}{}
\end{tabular} & $\begin{array}{l}n \\
\hat{v}\end{array}$ & $\overrightarrow{\hat{a}}$ & $\overrightarrow{0}$ & $\begin{array}{l}n \\
\hat{n} \\
\tilde{v}\end{array}$ & $\left|\begin{array}{l}\infty \\
0 \\
0 \\
-1\end{array}\right|$ & $\overrightarrow{\hat{n}}$ & $\overrightarrow{\vec{d}}$ & ڤ̂̀ \\
\hline$\stackrel{n}{n}$ & & $\frac{m}{m}$ & $\left|\begin{array}{l}\infty \\
\tilde{n} \\
\tilde{n}\end{array}\right|$ & 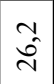 & $\stackrel{0}{\hat{\imath}}$ & $\begin{array}{l}m^{2} \\
\hat{n}^{2}\end{array}$ & $\hat{\vec{i}}$ & $\stackrel{\infty}{\hat{i}}$ & & 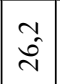 & $\hat{\imath}$ & $\mid \begin{array}{c}\hat{\imath} \\
\hat{\sim} \\
\tilde{v}\end{array}$ & $\begin{array}{l}0 \\
\tilde{U}\end{array}$ & $\begin{array}{l}\overrightarrow{0} \\
\stackrel{0}{2}\end{array}$ & $\tilde{\sigma}$ & 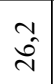 & $\begin{array}{c}0 \\
\hat{v}\end{array}$ & $\stackrel{\infty}{\stackrel{\infty}{=}}$ \\
\hline$\hat{\tilde{m}}$ & & $\vec{m}$ & $\begin{array}{l}m \\
\hat{n} \\
\tilde{n}\end{array}$ & $\stackrel{\sim}{\wedge}$ & $\widehat{\widehat{\curvearrowright}}$ & $\begin{array}{l}0 \\
\text { î } \\
\text { in }\end{array}$ & $\begin{array}{l}\infty \\
\hat{\imath} \\
\hat{v}\end{array}$ & $\begin{array}{l}\sigma \\
\vec{v}\end{array}$ & & $\overrightarrow{\hat{\infty}}$ & $\begin{array}{c}0 \\
0 \\
0 \\
N\end{array}$ & $\begin{array}{c}0 \\
\hat{m} \\
m\end{array}$ & $\begin{array}{l}+ \\
\stackrel{a}{二}\end{array}$ & $\begin{array}{l}n \\
\hat{\nu} \\
\nu_{1}^{2}\end{array}$ & \begin{tabular}{|l|}
$\infty$ \\
0 \\
0
\end{tabular} & & $\begin{array}{l}0 \\
\stackrel{+}{d}\end{array}$ & $\stackrel{\circ}{\vec{v}}$ \\
\hline . & 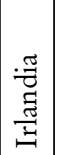 & 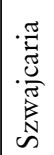 & $\left|\begin{array}{c}\cdot \frac{\pi}{2} \\
0 \\
0 \\
\tilde{z} \\
0 \\
z\end{array}\right|$ & 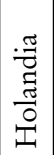 & 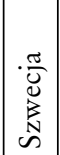 & 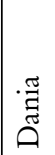 & 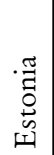 & 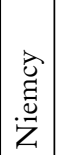 & 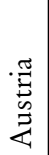 & $\left|\begin{array}{c}\hat{\theta} \\
\bar{U} \\
\text { U }\end{array}\right|$ & 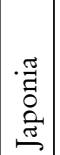 & 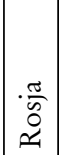 & 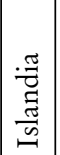 & 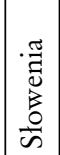 & 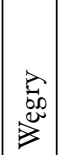 & $\frac{.5}{60}$ & 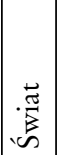 & $\begin{array}{l}\overline{\widetilde{N}} \\
\text { N }\end{array}$ \\
\hline
\end{tabular}




\begin{tabular}{|c|c|c|c|c|c|c|c|c|c|c|c|c|c|c|c|c|c|c|c|c|c|}
\hline$\vec{i}$ & $\stackrel{2}{\sim}^{2}$ & $\stackrel{N}{\sim}$ & $\hat{\tilde{v}}$ & $\hat{\tilde{v}}$ & $\begin{array}{l}\infty \\
\tilde{d}\end{array}$ & $\hat{\tilde{n}}$ & $\begin{array}{l}0 \\
\tilde{N}\end{array}$ & $\overrightarrow{\tilde{N}}$ & $\begin{array}{l}0 \\
\tilde{N}\end{array}$ & & $\hat{\hat{i}}$ & 只 & $\overrightarrow{\hat{i}}$ & Oे & $\hat{\sigma}_{2}$ & & & $\mid \begin{array}{l}0 \\
\infty \\
-0\end{array}$ & $\hat{\sigma}_{0}^{2}$ & $\stackrel{\Im}{\simeq}$ & $\begin{array}{l}+ \\
0 \\
0\end{array}$ \\
\hline$\frac{0}{8}$ & $\hat{\tilde{z}}$ & $\hat{\tilde{v}}$ & $\hat{\vec{i}}$ & $\begin{array}{l}\infty \\
\hat{i}\end{array}$ & $\stackrel{+}{\tilde{d}}$ & $\hat{\vec{\lambda}}$ & $\stackrel{n}{\vec{i}}$ & $\hat{\theta^{\prime}}$ & $\begin{array}{c}0 \\
\hat{v}\end{array}$ & $\stackrel{\infty}{\vec{i}}$ & $\stackrel{0}{\vec{i}}$ & $\hat{\sigma}$ & $\stackrel{t}{\sigma}$ & $\stackrel{0}{2}$ & $\stackrel{2}{2}$ & $\begin{array}{c}\infty \\
\infty \\
\infty \\
-1\end{array}$ & $\vec{\infty}$ & $\begin{array}{l}n \\
\hat{-}\end{array}$ & $\vec{n}$ & $\stackrel{+}{=}$ & $\overrightarrow{0}$ \\
\hline$\frac{n}{8}$ & 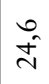 & $\overrightarrow{\hat{v}}$ & $\frac{\mathfrak{N}}{\hat{v}}$ & $\overrightarrow{0}$ & $\stackrel{+}{\vec{v}}$ & $\stackrel{\infty}{\vec{\lambda}}$ & $\stackrel{+}{\vec{v}}$ & $\begin{array}{l}n \\
\hat{N}\end{array}$ & $\begin{array}{l}\dot{v} \\
\tilde{v}\end{array}$ & 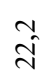 & $\hat{\vec{v}}$ & $\overrightarrow{\vec{v}}$ & $\stackrel{\sigma}{\sigma}$ & $\begin{array}{l}\infty \\
\infty \\
\infty\end{array}$ & $\stackrel{\infty}{\curvearrowright}$ & 2 & $\stackrel{+}{\sim}$ & $\begin{array}{l}0 \\
\infty \\
0\end{array}$ & $\stackrel{1}{\stackrel{5}{-}}$ & $\stackrel{\infty}{=}$ & $\begin{array}{l}0 \\
0 \\
0\end{array}$ \\
\hline 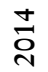 & $\begin{array}{l}\infty \\
\text { O }\end{array}$ & $\hat{\tilde{N}}$ & $\begin{array}{l}n \\
\infty \\
\infty\end{array}$ & $\hat{\sigma}$ & ڤn & $\stackrel{\vec{N}}{\vec{v}}$ & $\hat{\hat{D}^{\prime}}$ & $\hat{\sim}$ & $\begin{array}{l}\dot{v} \\
\tilde{N}\end{array}$ & $\hat{\vec{v}}$ & $\hat{\sim}$ & $\hat{\vec{v}}$ & $\stackrel{m}{\infty}$ & $\hat{\sigma}$ & $\begin{array}{c}\tilde{v} \\
\tilde{v}\end{array}$ & $\tilde{2}$ & $\stackrel{2}{2}$ & $\begin{array}{l}\dot{+} \\
\tilde{N}\end{array}$ & $\stackrel{\sim}{ \pm}$ & $\hat{\approx}$ & $\begin{array}{l}0 \\
\text { O }\end{array}$ \\
\hline$\stackrel{m}{\circ}$ & $\hat{\text { ?े }}$ & $\stackrel{0}{\tilde{N}}$ & $\begin{array}{l}n \\
\infty \\
\infty\end{array}$ & $\hat{\sigma}$ & ช̂. & $\begin{array}{l}\infty \\
\dot{0} \\
\dot{\gamma}\end{array}$ & $\begin{array}{l}\text { in } \\
\stackrel{0}{2}\end{array}$ & $\hat{\tilde{v}}$ & $\begin{array}{l}\tilde{z} \\
\tilde{z}\end{array}$ & $\stackrel{ }{N}$ & $\begin{array}{l}\stackrel{0}{\mathfrak{N}} \\
\text { in }\end{array}$ & $\stackrel{n}{\vec{N}}$ & $\stackrel{\infty}{\beth}$ & 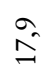 & $\begin{array}{l}\overrightarrow{0} \\
\vec{\sim}\end{array}$ & $\tilde{\sigma}^{2}$ & $\begin{array}{l}\stackrel{n}{0} \\
\infty \\
0\end{array}$ & $\begin{array}{l}+ \\
\dot{\theta} \\
\stackrel{N}{*}\end{array}$ & in & $\stackrel{0}{=}$ & $\hat{\sigma}$ \\
\hline$\stackrel{\text { ㄱ }}{\mathrm{O}}$ & $\begin{array}{l}n \\
\hat{2}\end{array}$ & î & $\stackrel{+}{\sim}$ & $\begin{array}{l}\infty \\
\hat{\sigma}\end{array}$ & $\hat{\sigma}$ & $\hat{\hat{o}}$ & $\begin{array}{l}0 \\
\ddot{0} \\
0\end{array}$ & $\begin{array}{l}\stackrel{1}{\sim} \\
\stackrel{\sim}{\sim}\end{array}$ & $\hat{\vec{v}}$ & $\stackrel{0}{\vec{i}}$ & $\begin{array}{l}0 \\
\tilde{d}\end{array}$ & $\stackrel{+}{i}$ & $\stackrel{ \pm}{\cong}$ & $\stackrel{n}{\cong}$ & $\hat{\sigma}$ & $\stackrel{2}{\approx}$ & $\begin{array}{l}0 \\
\infty \\
-\infty\end{array}$ & $\mid \begin{array}{l}0 \\
\infty \\
-0\end{array}$ & $\stackrel{+}{\sim}$ & $\stackrel{\infty}{=}$ & $\begin{array}{l}10 \\
\infty \\
\infty\end{array}$ \\
\hline$\overline{\bar{c}}$ & $\overrightarrow{0}$ & î & $\stackrel{\infty}{\vec{\sim}}$ & $\overrightarrow{\hat{v}}$ & $\begin{array}{l}0 \\
\infty \\
\infty\end{array}$ & $\stackrel{\vec{v}}{\vec{v}}$ & $\stackrel{\infty}{\vec{\sim}}$ & $\tilde{\sim}$ & $\begin{array}{l}2 \\
2\end{array}$ & 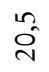 & $\overrightarrow{\tilde{N}}$ & $\stackrel{\vec{v}}{\hat{v}}$ & $\stackrel{ \pm}{\beth}$ & $\stackrel{2}{\cong}$ & $\hat{\sigma}$ & 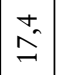 & $\begin{array}{l}0 \\
0 \\
0\end{array}$ & 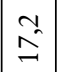 & $\hat{\jmath}$ & $\stackrel{0}{\sim}$ & $\begin{array}{l}\sigma_{f} \\
f\end{array}$ \\
\hline 응 & $\begin{array}{l}n \\
\text { in } \\
\text { ô }\end{array}$ & $\stackrel{0}{i}$ & $\stackrel{+}{\sim}$ & $\hat{\sim}$ & $\stackrel{0}{2}$ & $\begin{array}{c} \pm \\
\stackrel{Q}{N}\end{array}$ & $\stackrel{0}{\vec{i}}$ & $\hat{\vec{i}}$ & $\begin{array}{l}n \\
2 \\
2\end{array}$ & $\overrightarrow{\sigma^{2}}$ & $\stackrel{+}{\vec{v}}$ & $\begin{array}{l}\stackrel{n}{N} \\
\stackrel{N}{N}\end{array}$ & $\underbrace{0}_{0}$ & 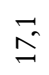 & $\stackrel{+}{\sigma}$ & $\stackrel{ \pm}{\check{\Xi}}$ & $\stackrel{m}{n}$ & $\mid \begin{array}{l}\infty \\
\hat{0} \\
-0\end{array}$ & $\hat{0}$ & $\begin{array}{l}0 \\
\simeq \\
\simeq\end{array}$ & $\begin{array}{l}0 \\
n^{n}\end{array}$ \\
\hline ઠ̊̀ & के & $\frac{0}{i}$ & $\stackrel{\hat{ \pm}}{\tilde{ \pm}}$ & $\hat{\vec{v}}$ & ช̂ & $\hat{\sigma}$ & $\begin{array}{l}0 \\
\stackrel{0}{0}\end{array}$ & $\hat{\tilde{v}}$ & $\begin{array}{l} \pm \\
\stackrel{ \pm}{=}\end{array}$ & $\stackrel{2}{\sigma}$ & $\tilde{\vartheta}^{2}$ & $\stackrel{\infty}{\tilde{N}}$ & $\underbrace{0}_{0}$ & $\stackrel{n}{\cong}$ & $\begin{array}{l}0 \\
\infty \\
\infty\end{array}$ & $\overrightarrow{0}$ & $\begin{array}{l}0 \\
\pm \\
\pm\end{array}$ & $\begin{array}{l}\infty \\
2\end{array}$ & $\hat{O}^{2}$ & $\stackrel{0}{=}$ & $\begin{array}{l}\sigma_{2} \\
n^{2}\end{array}$ \\
\hline ஜ̊ & $\hat{\tilde{N}}$ & $\hat{\tilde{v}}$ & $\begin{array}{l}0 \\
f \\
\tilde{m}\end{array}$ & $\hat{\tilde{v}}$ & $\stackrel{+}{0}$ & $\begin{array}{l}0 \\
\mathfrak{d}\end{array}$ & $\begin{array}{l}0 \\
\hat{n}\end{array}$ & $\hat{\vec{v}}$ & $\begin{array}{l}\hat{\tilde{N}} \\
\hat{n}\end{array}$ & $\stackrel{v}{N}$ & $\stackrel{+}{\tilde{d}}$ & $\stackrel{\infty}{\tilde{d}}$ & $\stackrel{0}{\infty}$ & $\stackrel{\circ}{\Omega}$ & 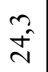 & $\begin{array}{c}\hat{n} \\
\hat{n}\end{array}$ & $\hat{n}$ & $\begin{array}{l}\tilde{m} \\
\pm \\
\pm\end{array}$ & $\begin{array}{l}n \\
0 \\
0\end{array}$ & $\vec{n}$ & $\overrightarrow{0}$ \\
\hline Oิ & $\hat{\tilde{N}}$ & $\stackrel{n}{\stackrel{n}{v}}$ & $\begin{array}{l}\infty \\
\stackrel{m}{m}\end{array}$ & $\hat{\hat{v}^{2}}$ & $\hat{\vec{v}}$ & $\tilde{v}^{2}$ & $\overrightarrow{ \pm}$ & $\frac{\sigma_{\hat{v}}}{\vec{v}}$ & $\begin{array}{c}0 \\
\hat{v}\end{array} \mid$ & $\begin{array}{l}0 \\
\text { i }\end{array}$ & $\stackrel{+}{\stackrel{i}{N}}$ & กิ & $\stackrel{\hat{\sigma}}{\sigma}$ & $\stackrel{\infty}{0}$ & $\begin{array}{l}n \\
\stackrel{+}{N}\end{array}$ & $\begin{array}{l}0 \\
\infty \\
\infty\end{array} \mid$ & $\stackrel{n}{\beth}$ & $\begin{array}{l}\infty \\
0 \\
0\end{array}$ & $\hat{\tilde{y}}$ & $\begin{array}{l}n \\
i n \\
n\end{array}$ & $\hat{\imath}$ \\
\hline ర్ & $\hat{\sim}$ & $\stackrel{\infty}{\hat{N}}$ & 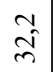 & $\overrightarrow{\mathbb{N}^{0}}$ & $\hat{\tilde{v}}$ & $\begin{array}{l}0 \\
\vec{u}\end{array}$ & $\stackrel{0}{\hat{v}}$ & $\stackrel{\infty}{\vec{N}}$ & $\stackrel{m}{\vec{v}}$ & $\hat{\tilde{N}}$ & $\begin{array}{l}\infty \\
\stackrel{-}{\beth}\end{array}$ & $\stackrel{n}{n}$ & $\stackrel{\infty}{\beth}$ & $\stackrel{+}{\stackrel{+}{N}}$ & $\begin{array}{l}0 \\
\stackrel{ \pm}{N}\end{array}$ & $\stackrel{0}{\stackrel{0}{\Omega}}$ & $\stackrel{2}{2}$ & $\overrightarrow{0}$ & ב̂ & $\begin{array}{l}0 \\
\text { in }\end{array}$ & $\begin{array}{c}\dot{y} \\
\dot{n}\end{array}$ \\
\hline ํㅗㅇ & $\stackrel{\circ}{\sim}$ & $\hat{\tilde{z}}$ & $\begin{array}{l}\sigma_{n} \\
\hat{m}\end{array}$ & $\begin{array}{c}\stackrel{1}{\infty} \\
\stackrel{N}{N}\end{array}$ & $\hat{\tilde{v}}$ & $\hat{\vec{\lambda}}$ & $\begin{array}{l}\infty \\
\hat{i}\end{array}$ & $\frac{0}{\vec{v}}$ & $\hat{\vec{v}}$ & $\overrightarrow{\tilde{a}}$ & $\begin{array}{l}0 \\
\tilde{N}\end{array}$ & $\hat{\vartheta}$ & $\cong$ & กิ & $\begin{array}{l}+ \\
\stackrel{ \pm}{v}\end{array}$ & $\hat{\Xi}$ & $\begin{array}{l}0 \\
0^{0} \\
0^{2}\end{array}$ & $\stackrel{0}{\Omega}$ & $\stackrel{+}{\sim}$ & $\begin{array}{l}0 \\
\stackrel{0}{n}\end{array}$ & $\begin{array}{c}0 \\
i n \\
n\end{array}$ \\
\hline ষ্ণ & $\hat{\sim}$ & $\overrightarrow{\hat{v}}$ & $\begin{array}{l}\hat{n} \\
\hat{n}\end{array}$ & $\hat{\imath}^{2}$ & $\overrightarrow{\tilde{v}}$ & $\stackrel{\infty}{\vec{\sim}}$ & $\stackrel{0}{\tilde{\imath}}$ & $\begin{array}{c}0 \\
\vec{v}\end{array}$ & $\begin{array}{l}n \\
0 \\
0 \\
\end{array} \mid$ & $\stackrel{\infty}{\vec{N}}$ & $\tilde{\sigma}^{-}$ & $\hat{\tilde{N}}$ & $\hat{ \pm}$ & $\stackrel{\infty}{0}$ & $\stackrel{0}{\tilde{v}}$ & $\begin{array}{l}0 \\
\text { O } \\
\text { in }\end{array}$ & $\hat{\approx}$ & $\begin{array}{l}n \\
n\end{array}$ & ñ & $\stackrel{0}{n}$ & $\begin{array}{l}n \\
\cong\end{array}$ \\
\hline ஷ̊̀ & $\stackrel{+}{\vec{v}}$ & ป̂ & $\begin{array}{l}\hat{\mathrm{s}} \\
\hat{\sim}\end{array}$ & $\stackrel{n}{\hat{N}}$ & $\hat{\vartheta}$ & $\stackrel{\sim}{\vec{v}}$ & $\begin{array}{l}0 \\
\tilde{u}\end{array}$ & $\overrightarrow{\vec{i}}$ & $\begin{array}{l}\dot{\sigma}_{n} \\
\stackrel{\hat{\sigma}}{ }\end{array}$ & $\stackrel{\sim}{\sim}$ & $\hat{\vec{N}}$ & $\hat{\hat{N}^{\prime}}$ & $\overbrace{}^{n}$ & ڤn & $\overrightarrow{\vec{v}}$ & $\hat{\vec{v}}$ & $\stackrel{n}{\bumpeq}$ & $\vec{n}$ & $\overrightarrow{0}$ & $\stackrel{2}{n}$ & $\vec{\infty}$ \\
\hline రิ & $\begin{array}{l}n \\
\text { in } \\
\text { ñ }\end{array}$ & $\begin{array}{l}0 \\
\tilde{N}\end{array}$ & $\begin{array}{l}0 \\
\infty_{0}^{0} \\
\sim\end{array}$ & $\hat{\hat{m}^{\prime}}$ & $\overrightarrow{\hat{v}}$ & $\stackrel{n}{\vec{v}}$ & $\overrightarrow{\hat{n}}$ & $\hat{\vec{v}}$ & $\hat{\tilde{v}}$ & $\stackrel{n}{\hat{N}}$ & 望 & $\stackrel{n}{\vec{N}}$ & $\hat{n}$ & $\overrightarrow{\vec{i}}$ & $\hat{\bar{v}}$ & $\begin{array}{l}\hat{\sigma} \\
\hat{\sigma}\end{array}$ & $\stackrel{m}{\infty}$ & $\begin{array}{l}n \\
n \\
n\end{array}$ & $\begin{array}{l}0 \\
气\end{array}$ & $\stackrel{\sim}{n}$ & $\hat{\sigma}$ \\
\hline$\overline{\mathrm{O}}$ & $\stackrel{\circ}{\vec{N}}$ & $\hat{\tilde{N}}$ & $\vec{m}$ & $\stackrel{\infty}{m}$ & $\stackrel{+}{\tilde{v}}$ & $\stackrel{\infty}{\vec{\sim}}$ & $\begin{array}{l}\stackrel{+}{\sim} \\
\stackrel{\sim}{N}\end{array}$ & $\begin{array}{l}\infty \\
\hat{\sim}\end{array}$ & 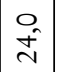 & $\hat{\tilde{v}}$ & $\tilde{\Omega}$ & $\hat{\vec{N}}$ & $\stackrel{ \pm}{\cong}$ & $\frac{v}{N}$ & $\begin{array}{l}0 \\
\tilde{N}\end{array}$ & $\begin{array}{l}\infty \\
\hat{\vec{v}}\end{array}$ & $\stackrel{0}{\stackrel{0}{2}}$ & $\stackrel{m}{ \pm}$ & $\hat{\tilde{A}}$ & $\begin{array}{l}n \\
n \\
n\end{array}$ & $\begin{array}{l}n \\
\infty \\
0\end{array}$ \\
\hline 牙 & 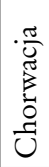 & 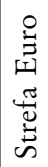 & 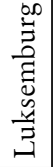 & 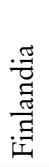 & 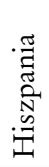 & 岇 & 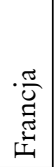 & 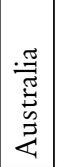 & $\left|\begin{array}{c}\frac{\pi}{v} \\
\frac{\pi}{\sigma} \\
\frac{\tilde{s}}{\omega} \\
\frac{\pi}{\omega}\end{array}\right|$ & $\overbrace{\substack{1 \\
0}}^{0}$ & 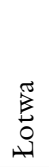 & $\frac{\stackrel{0}{ت}}{\tilde{U}}$ & $\frac{\frac{\pi}{4}}{0}$ & $\frac{\vec{A}}{\frac{\hat{U}}{0}}$ & 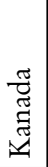 & 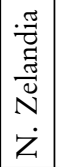 & 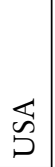 & 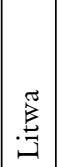 & 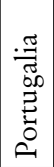 & 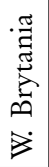 & 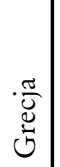 \\
\hline
\end{tabular}


sumę nakładów brutto na środki trwałe $(I)$, deficytu budżetowego $(G-T)$ oraz eksportu netto, czyli stanu bilansu handlowego $(X-Z)$ - zatem to w znacznej mierze wysoka nadwyżka handlowa była tym czynnikiem, który zdecydował o pozycji krajów o najwyższej stopie oszczędzania. Wynika to więc $\mathrm{z}$ tego trywialnego, ale podstawowego dla makroekonomii równania bilansów makroekonomicznych ${ }^{8}$ :

$$
S=I+(G-T)+(X-Z) .
$$

Oszczędności $(S)$ są generowane przez gospodarstwa domowe $\left(S_{H}\right)$ i przedsiębiorstwa (tzw. oszczędności kapitalistów $S_{F}$ ). Warto przypomniéc spostrzeżenie Kaleckiego, że to właśnie inwestycje firm określają poziom zysków zatrzymanych, czyli oszczędności firm, natomiast oszczędności gospodarstw domowych stanowią dla tych zysków ograniczenie finansowe (Toporowski, 2017). Jeśli zatem rozdzielimy $S$ na te dwa źródła ich generowania, to (Toporowski, 2017):

$$
S_{H}+S_{F}=I+(G-T)+(X-Z) .
$$

Zatem, jak zauważył Josef Steindl (1982; 1989, s. 71-78, za: Toporowski, 2017):

$$
S_{F}=I-S_{H}+(G-T)+(X-Z) .
$$

Jeśli więc dla uproszczenia obrazu założymy zbilansowanie wymiany z zagranicą i budżetu państwa, to bezpośrednio widać, że zatrzymane zyski firm $S_{F}$ są równe nakładom inwestycyjnym pomniejszonym o oszczędności gospodarstw domowych:

$$
\mathrm{S}_{\mathrm{F}}=\mathrm{I}-\mathrm{S}_{\mathrm{H}}
$$

Tak więc im większy strumień jest „wyrywany” z obiegu w formie oszczędności gospodarstw domowych, tym mniej zostanie firmom jako ich środki odłożone, muszą zatem korzystać z szerokich form kredytowania. I odwrotnie: przy niskich oszczędnościach gospodarstw domowych - co w Polsce jest oczywistą konsekwencją niskiego poziomu dochodów - wyższe są zyski

8 Niżej podpisany analizował je w wersji określającej poziom deficytu budżetowego: $(G-T)=(S-I)+(Z-X)$. Por. Żyżyński, 2010. 
zatrzymane firm, z których finansują one swe inwestycje - i w konsekwencji obserwuje się słabe tempo lub brak wzrostu inwestycji finansowanych kredytem. Źródłem kredytów, jako formy uaktywnienia pasywów instytucji finansowych, są między innymi właśnie tworzące te pasywa oszczędności gospodarstw domowych. Przyjrzyjmy się, jaka jest relacja między oszczędnościami jako strumieniem generowanym corocznie w gospodarce a kredytami, które są pewną miarą realnego zaangażowania inwestycyjnego w danej gospodarce.

W tabeli 3 ujęte zostały kredyty dla sektora prywatnego - jak zauważają analitycy IMF - większość badań empirycznych od lat 70. XX wieku stopień rozwoju systemu finansowego określa poprzez współczynnik relacji prywatnego kredytu do PKB (Sahay, Čihák i in., 2015, s. 6). W tym ujęciu chodzi o środki pieniężne dostarczane sektorowi prywatnemu w postaci pożyczek, różnych papierów dłużnych, kredytów handlowych itp. - zarówno przedsiębiorstwom, jak i gospodarstwom domowym - przez różne instytucje finansowe (banki, fundusze inwestycyjne, emerytalne, ubezpieczeniowe) nabywające do swych aktywów różne rodzaje instrumentów dłużnych.

Jak widzimy, Polska na tej liście zajmuje daleką pozycję, kredyty stanowią nieco ponad $50 \%$ PKB, podobnie jak w innych rajach postsocjalistycznych, podczas gdy w krajach rozwiniętych jest to zwykle ok. 100\% PKB, a nawet o kilkadziesiąt procent więcej, do prawie dwukrotności w USA. Na liście przodują właśnie USA oraz Szwajcaria, Dania, Japonia, Norwegia - i co szczególnie godne podkreślenia - Chiny, które nie poddały się wpływom tzw. Nowej Ekonomii. Wskaźnik dla krajów OECD jest prawie o połowę wyższy od PKB, norma światowa o 30\% przekracza PKB, ale Unia Europejska, jak można zauważyć, nie zdołała aktywnością kredytową przekroczyć wartości PKB, choć zdarzało się to, co prawda niewiele, o kilkanaście procent w latach wcześniejszych. Co ciekawe, gorzej wygląda sytuacja w strefie euro i w tak ważnych krajach, jak Niemcy, Austria, Włochy czy Belgia, plasujące się $\mathrm{w}$ dolnej części listy.

W momencie gdy rośnie aktywność gospodarcza w sferze realnej, rośnie również sektor finansowy - w odpowiedzi na rosnące zapotrzebowanie na jego usługi (Sahay, Čihák i in., 2015, s. 6). Jak lapidarnie stwierdziła, jeszcze w połowie ubiegłego wieku, Joan Robinson (1952, s. 86): where enterprise, leads, finance follows. Kilkanaście lat później, w 1998 roku, Levine i Zervos wykazali zaś, że istnieje wyraźny związek przyczynowy między rozwojem sfery finansów a wzrostem gospodarczym - pierwsze implikuje drugie (Sahay, Čihák $\mathrm{i}$ in., 2015, s. 8). Przywołani autorzy z IMF w wyniku swoich badań potwierdzili jednak, że jest coś takiego, jak nadmierny rozrost systemu finansowego, 


\begin{tabular}{|c|c|c|c|c|c|c|c|c|c|c|c|c|c|c|c|c|c|c|c|}
\hline 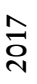 & & & $\begin{array}{l}0 \\
0 \\
0 \\
0\end{array}$ & & $\begin{array}{l}\infty \\
\hat{n}^{n} \\
n\end{array}$ & $\begin{array}{l}\text { mo } \\
f^{0}\end{array}$ & & & ô & 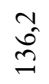 & $\begin{array}{l}\text { त̂ } \\
\text { }\end{array}$ & & & $\begin{array}{l}\tilde{n} \\
\stackrel{\Xi}{\Xi}\end{array}$ & $\stackrel{\infty}{\Xi}$ & $\begin{array}{l}\text { గ̂ } \\
\text { ठํ }\end{array}$ & $\begin{array}{l}\infty \\
\hat{\varrho} \\
\underline{0}\end{array}$ & $\begin{array}{l}\text { 오 } \\
\text { Oे }\end{array}$ & \\
\hline 을 & $\tilde{\mathfrak{z}}$ & $\stackrel{m}{n}$ & $\begin{array}{l}\hat{\sigma} \\
\hat{\sigma}\end{array}$ & $\hat{i}$ & 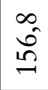 & $\begin{array}{l}\stackrel{\sigma}{ \pm} \\
\dot{ \pm}\end{array}$ & $\begin{array}{l}\infty \\
\mathbb{J}^{\prime} \\
-\end{array}$ & & $\stackrel{i n}{\stackrel{f}{ \pm}}$ & $\begin{array}{l}\stackrel{m}{2} \\
\stackrel{2}{2}\end{array}$ & 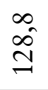 & $\begin{array}{l}a \\
\infty \\
\tilde{y} \\
\tilde{y}\end{array}$ & & $\begin{array}{l}\infty \\
\stackrel{0}{=}\end{array}$ & $\hat{n}$ & $\begin{array}{l}+ \\
\tilde{i} \\
\stackrel{-}{\sim}\end{array}$ & $\stackrel{\cong}{=}$ & $\stackrel{\infty}{=}$ & \\
\hline$\stackrel{n}{\stackrel{2}{2}}$ & $\begin{array}{l}\infty \\
\infty \\
\infty \\
\infty\end{array}$ & $\stackrel{t}{\stackrel{t}{\prime}}$ & $\begin{array}{l}\hat{o} \\
\stackrel{0}{2}\end{array}$ & $\begin{array}{l}\bar{a} \\
\underline{v}\end{array}$ & $\begin{array}{l}0 \\
\text { ñ } \\
n\end{array}$ & $\begin{array}{l}+ \\
\infty \\
\stackrel{\sim}{\sim}\end{array}$ & $\begin{array}{l}\tilde{A} \\
\text { İ }\end{array}$ & & $\begin{array}{l}0 \\
\overbrace{}^{0} \\
ٍ\end{array}$ & $\begin{array}{l}\infty \\
\text { â } \\
\end{array}$ & 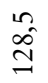 & $\begin{array}{l}0 \\
0 \\
\text { In }\end{array}$ & & ڤू & $\stackrel{\circ}{\varrho}$ & $\begin{array}{l}\dot{+} \\
\stackrel{\sigma}{\sigma}\end{array}$ & $\begin{array}{l}\stackrel{\circ}{\Xi} \\
\stackrel{\Rightarrow}{a}\end{array}$ & $\stackrel{\infty}{\stackrel{\infty}{\Xi}}$ & $\alpha$ \\
\hline$\underset{⿱ 乛}{\stackrel{\Xi}{d}}$ & 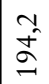 & ڤֵ & $\stackrel{m}{\cong}$ & $\hat{\hat{\delta}}$ & $\overrightarrow{\text { 守 }}$ & $\begin{array}{l}\stackrel{\sigma}{ } \\
\stackrel{\oplus}{\Xi}\end{array}$ & $\stackrel{\infty}{\vec{\Xi}}$ & & $\begin{array}{l}\hat{N} \\
\stackrel{\sim}{\simeq}\end{array}$ & $\stackrel{+}{\stackrel{2}{2}}$ & $\frac{\sim}{n}$ & $\begin{array}{l}0 \\
\tilde{I}\end{array}$ & & $\begin{array}{l}0 \\
0 \\
0 \\
0\end{array}$ & $\stackrel{+}{\stackrel{+}{0}}$ & $\begin{array}{l}\stackrel{0}{0} \\
\stackrel{0}{0}\end{array}$ & 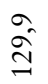 & $\hat{\beth}$ & $\vec{d}$ \\
\hline$\frac{m}{\sigma}$ & $\begin{array}{l}n \\
\hat{\Omega} \\
\Omega\end{array}$ & $\overbrace{0}^{2}$ & $\stackrel{0}{\stackrel{1}{\cong}}$ & ช్ర & $\hat{n}$ & \begin{tabular}{l}
$\infty$ \\
$\stackrel{+}{\beth}$ \\
\multirow{2}{*}{}
\end{tabular} & $\begin{array}{l}0 \\
\text { I } \\
\text { I }\end{array}$ & & $\begin{array}{l}\text { 오 } \\
\stackrel{\Xi}{\simeq}\end{array}$ & 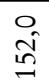 & $\begin{array}{l}\tilde{N} \\
\tilde{\approx}\end{array}$ & 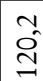 & & $\hat{n}$ & $\stackrel{\sim}{\cong}$ & $\stackrel{n}{a}$ & \begin{tabular}{l}
$\infty$ \\
$\dot{f}$ \\
\multirow{I}{n}{}
\end{tabular} & $\stackrel{m}{\tilde{z}}$ & $\begin{array}{l}0 \\
\text { o }\end{array}$ \\
\hline$\frac{\text { Tे }}{\mathrm{D}}$ & $\vec{a}$ & $\begin{array}{l}\hat{\sigma} \\
0\end{array}$ & $\overrightarrow{0}$ & $\begin{array}{l}\tilde{\sigma}^{\prime} \\
\stackrel{n}{n}\end{array}$ & $\begin{array}{l}10 \\
\hat{0} \\
\mathbb{N}\end{array}$ & $\hat{\tilde{\Xi}}$ & $\begin{array}{l}n \\
\hat{2}\end{array}$ & & $\hat{\Xi}$ & $\hat{\Omega}^{n}$ & $\overrightarrow{0}$ & $\vec{\Xi}$ & & $\begin{array}{l}2 \\
\text { fo } \\
0\end{array}$ & $\begin{array}{l}+ \\
\infty \\
=\end{array}$ & $\begin{array}{l}\mathcal{N} \\
\infty \\
\infty\end{array}$ & $\begin{array}{l}a \\
\hat{\delta} \\
\sim\end{array}$ & $\begin{array}{l}\hat{N} \\
\hat{n}\end{array}$ & 0 \\
\hline $\bar{\nabla}$ & $\stackrel{a}{\hat{\beth}}$ & $\begin{array}{l}0 \\
\text { Oீ } \\
\text { - }\end{array}$ & $\stackrel{N}{\infty}$ & $\begin{array}{l}0 \\
\stackrel{0}{n}\end{array}$ & $\begin{array}{l}\infty \\
\tilde{I}\end{array}$ & $\begin{array}{l}0 \\
\stackrel{\cong}{\simeq}\end{array}$ & 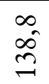 & & 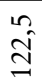 & $\stackrel{\stackrel{\sim}{\Omega}}{\bumpeq}$ & 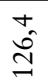 & 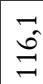 & & $\hat{0}$ & $\begin{array}{l}\infty \\
\stackrel{n}{=}\end{array}$ & $\begin{array}{l}t_{0} \\
\infty\end{array}$ & $\begin{array}{l}\infty \\
0 \\
0 \\
0\end{array}$ & గ్ & $\infty$ \\
\hline 응 & $\begin{array}{l}\stackrel{2}{N} \\
\infty \\
-\end{array}$ & $\stackrel{\hat{n}}{\stackrel{n}{n}}$ & $\stackrel{0}{\stackrel{2}{\sigma}}$ & $\begin{array}{l}\hat{\sigma} \\
\stackrel{n}{n}\end{array}$ & $\begin{array}{l}n \\
\stackrel{n}{2} \\
\end{array}$ & $\begin{array}{l}\stackrel{N}{O} \\
\stackrel{I}{\simeq}\end{array}$ & $\begin{array}{l}\text { O } \\
\text { 吾 }\end{array}$ & $\hat{\imath}$ & $\begin{array}{l}\hat{\beth} \\
\stackrel{\Xi}{\approx}\end{array}$ & $\begin{array}{l}\widehat{\sigma} \\
\hat{\infty} \\
\infty\end{array}$ & $\begin{array}{l} \pm \\
\stackrel{ \pm}{\Xi}\end{array}$ & $\stackrel{\mathfrak{I}}{\mathcal{I}}$ & & $\begin{array}{l}0 \\
\sigma\end{array}$ & $\stackrel{\vec{n}}{=}$ & $\begin{array}{l}\hat{\Omega} \\
\hat{\Omega}\end{array}$ & $\hat{n}$ & $\begin{array}{l}3 \\
n^{n} \\
n\end{array}$ & ڤn \\
\hline Oे & $\stackrel{\infty}{\stackrel{\infty}{=}}$ & $\begin{array}{l}\infty \\
\infty \\
\stackrel{0}{n}\end{array}$ & $\stackrel{3}{\tilde{N}}$ & $\begin{array}{l}\tilde{\sigma} \\
\hat{\theta}\end{array}$ & 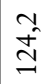 & $\begin{array}{l}\text { O0 } \\
\stackrel{\sim}{\simeq}\end{array}$ & $\begin{array}{l}\hat{\tilde{y}} \\
\text { 年 }\end{array}$ & $\vec{i}$ & $\begin{array}{l}\infty \\
\tilde{I}\end{array}$ & $\begin{array}{l}\sigma \\
\dot{\sigma} \\
\vec{\sigma}\end{array}$ & $\stackrel{\hat{\Xi}}{\cong}$ & \begin{tabular}{l}
\multirow{2}{*}{} \\
$\stackrel{1}{I}$
\end{tabular} & & ָี & $\stackrel{0}{\infty^{\circ}}$ & $\begin{array}{l}0 \\
\stackrel{0}{0}\end{array}$ & 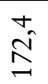 & $\begin{array}{l}\infty \\
\stackrel{\infty}{n} \\
\sim\end{array}$ & ก \\
\hline 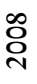 & $\begin{array}{l}0 \\
\infty \\
\infty \\
\infty\end{array}$ & $\stackrel{2}{q}^{2}$ & $\stackrel{\sim}{\approx}$ & 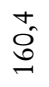 & $\hat{\overrightarrow{0}}$ & $\stackrel{\partial}{\underline{\Xi}}$ & $\begin{array}{l}\tilde{y} \\
\tilde{y}\end{array}$ & $\begin{array}{l}+ \\
+\end{array}$ & $\overrightarrow{\tilde{I}}$ & $\hat{\jmath}$ & $\begin{array}{l}0 \\
\stackrel{0}{0} \\
=\end{array}$ & $\begin{array}{l}+ \\
\text { Oे } \\
\text { v }\end{array}$ & $\begin{array}{l}+ \\
\stackrel{ \pm}{I}\end{array}$ & Ǒ & $\stackrel{\cong}{\Xi}$ & $\overrightarrow{0}$ & $\stackrel{\overbrace{}}{\stackrel{2}{\Omega}}$ & $\hat{n}$ & 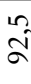 \\
\hline 宂 & 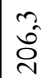 & $\begin{array}{l}\vec{\pi} \\
\stackrel{n}{=}\end{array}$ & $\begin{array}{l}n \\
+ \\
\infty \\
\infty\end{array}$ & $\begin{array}{l}\infty \\
\hat{\theta} \\
\underline{\theta}\end{array}$ & $\hat{n}$ & $\stackrel{n}{\stackrel{n}{O}}$ & $\stackrel{2}{\stackrel{2}{ \pm}}$ & $\begin{array}{l}0 \\
f\end{array}$ & $\begin{array}{l}\hat{O} \\
\hat{-}\end{array}$ & $\stackrel{2}{\triangleq}$ & $\stackrel{\infty}{\Xi}$ & $\begin{array}{l}\overrightarrow{0} \\
\stackrel{1}{1}\end{array}$ & $\hat{\tilde{\beth}}$ & $\hat{\infty}^{0}$ & $\stackrel{n}{\stackrel{n}{ \pm}}$ & $\begin{array}{l}+ \\
\dot{\delta} \\
\infty\end{array}$ & $\overrightarrow{\hat{\sigma}}$ & $\stackrel{\tilde{I}}{\tilde{I}}$ & $\infty$ \\
\hline ঃু & $\hat{\hat{\Xi}}$ & $\hat{\hat{n}}$ & $\begin{array}{l}0 \\
a_{0} \\
0\end{array}$ & 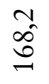 & مू & $\begin{array}{l}0 \\
\hat{a}\end{array}$ & $\begin{array}{l}0 \\
0 \\
0 \\
\pm \\
1\end{array}$ & $\tilde{2}^{2}$ & $\begin{array}{l}\text { O } \\
\stackrel{+}{=}\end{array}$ & $\begin{array}{l}0 \\
n \\
n \\
n\end{array}$ & $\hat{\overbrace{}}^{2}$ & $\overrightarrow{\hat{I}}$ & $\begin{array}{l}\infty \\
\infty \\
\infty\end{array}$ & $\stackrel{0}{\stackrel{1}{N}}$ & $\begin{array}{l}0 \\
\stackrel{+}{ \pm}\end{array}$ & $\begin{array}{l}n \\
n \\
n\end{array}$ & $\begin{array}{l}\vec{\delta} \\
\stackrel{n}{n}\end{array}$ & $\stackrel{+}{\stackrel{\sigma}{\Omega}}$ & $\infty$ \\
\hline 菅 & $\begin{array}{l}\infty \\
\stackrel{\infty}{\infty} \\
\infty\end{array}$ & $\begin{array}{l}\infty \\
\stackrel{q}{ \pm}\end{array}$ & $\begin{array}{l}n \\
\text { in }\end{array}$ & $\begin{array}{l}\hat{0} \\
\stackrel{2}{2}\end{array}$ & $\stackrel{\infty}{=}$ & $\begin{array}{l}\text { 응 } \\
\text { Oㅇ }\end{array}$ & $\underset{\Xi}{\stackrel{\sim}{ \pm}}$ & 0 & $\begin{array}{l}\text { ô } \\
\text { ô }\end{array}$ & $\begin{array}{l}\stackrel{+}{ \pm} \\
\stackrel{ \pm}{+}\end{array}$ & $\sigma_{\alpha}$ & 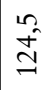 & $\hat{\tilde{N}}$ & $\stackrel{N}{\wedge}$ & $\begin{array}{l}n \\
\cong\end{array}$ & $\frac{\sigma}{\vec{\lambda}}$ & $\begin{array}{l}n \\
\cong \\
\cong\end{array}$ & $\stackrel{\widetilde{N}}{\stackrel{ \pm}{ \pm}}$ & $\overrightarrow{0}$ \\
\hline 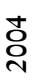 & $\begin{array}{l}\hat{\sigma} \\
\hat{\infty}\end{array}$ & $\begin{array}{l}\text { Î } \\
\text { f̂ }\end{array}$ & $\begin{array}{l}0 \\
\dot{f} \\
i^{n}\end{array}$ & $\stackrel{n}{\cong}$ & $\begin{array}{l}0 \\
\infty \\
=\end{array}$ & $\stackrel{+}{\stackrel{+}{0}}$ & $\begin{array}{l}\overrightarrow{\hat{\sigma}} \\
\stackrel{\sim}{\sim}\end{array}$ & $\begin{array}{l}0 \\
\stackrel{0}{0}\end{array}$ & $\overrightarrow{\hat{\sigma}}$ & $\begin{array}{l}+\dot{ } \\
\stackrel{\sim}{\sim}\end{array}$ & $\hat{\tilde{~}}$ & $\hat{\tilde{I}}$ & $\begin{array}{l}\sigma \\
\text { f́ } \\
\text { - }\end{array}$ & $\begin{array}{l}0 \\
0 \\
n\end{array}$ & 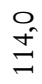 & $\begin{array}{l}0 \\
\dot{0}\end{array}$ & $\hat{\hat{n}}$ & $\vec{\Xi}$ & $\begin{array}{l}0 \\
\text { no }\end{array}$ \\
\hline Oֶ. & $\begin{array}{l}0 \\
\stackrel{0}{0} \\
\end{array}$ & 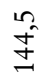 & $\overrightarrow{\underline{0}}$ & $\begin{array}{l}n \\
0 \\
\infty \\
\infty\end{array}$ & $\stackrel{\hat{\beth}}{\stackrel{n}{\beth}}$ & $\begin{array}{l}\hat{\sigma} \\
\stackrel{0}{0}\end{array}$ & $\overrightarrow{\hat{\Omega}}$ & $\hat{\sigma}$ & $\begin{array}{l}\dot{\sigma} \\
\alpha\end{array}$ & $\begin{array}{l}\hat{0} \\
\hat{n}\end{array}$ & $\begin{array}{l}\hat{\alpha} \\
\text { ó }\end{array}$ & 吉 & $\overrightarrow{\hat{j}}$ & $\hat{n}$ & $\overrightarrow{0}$ & â & $\begin{array}{l}+t \\
\dot{0}\end{array}$ & $\begin{array}{l}0 \\
\stackrel{0}{0}\end{array}$ & 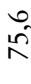 \\
\hline ర్రి & $\hat{\hat{0}}$ & $\vec{\exists}$ & $\begin{array}{l}0 \\
\stackrel{0}{ \pm}\end{array}$ & $\begin{array}{l}\infty \\
\stackrel{\infty}{0}\end{array}$ & $\stackrel{n}{\cong}$ & $\begin{array}{l}0 \\
\text { î } \\
\underline{1}\end{array}$ & $\begin{array}{l}\hat{\hat{v}} \\
\hat{\sim}\end{array}$ & 0 & $\frac{n}{\sigma}$ & 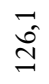 & $\begin{array}{l}\infty \\
\hat{\Omega}\end{array}$ & $\begin{array}{l}0 \\
\text { On } \\
\text { In }\end{array}$ & $\hat{\tilde{0}}$ & $\begin{array}{l}\sigma \\
\dot{N}\end{array}$ & $\hat{0}$ & $\hat{\kappa}^{2}$ & $\begin{array}{l}\dot{t} \\
\text { ă }\end{array}$ & $\begin{array}{l}\circ \\
\stackrel{\circ}{\equiv}\end{array}$ & تీ \\
\hline$\overline{\mathrm{D}}$ & $\stackrel{2}{2}$ & $\begin{array}{l}\text { O } \\
\text { ơ } \\
\end{array}$ & $\begin{array}{l}\infty \\
\infty \\
\stackrel{0}{2}\end{array}$ & $\stackrel{\sim}{\infty}$ & $\stackrel{\circ}{O}$ & $\hat{\sigma}^{2}$ & $\hat{\overbrace{}}$ & $\begin{array}{l}\hat{0} \\
0\end{array}$ & $\begin{array}{l}\hat{\infty} \\
\infty \\
\infty\end{array}$ & $\frac{a}{\vec{I}}$ & $\begin{array}{l}n \\
\text { ô }\end{array}$ & $\tilde{\tilde{\Omega}}$ & $\stackrel{\sim}{\curvearrowright}$ & $\stackrel{0}{n}$ & $\underline{\Xi}$ & $\begin{array}{l}\infty \\
\infty^{\infty}\end{array}$ & $\vec{n}$ & $\begin{array}{l}0 \\
\text { in } \\
=\end{array}$ & 읏 \\
\hline 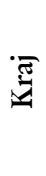 & 后 & 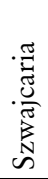 & 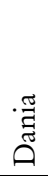 & 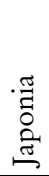 & 矛 & 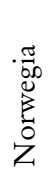 & $\overbrace{\substack{1 \\
0}}^{\theta}$ & $\begin{array}{l}\frac{\vec{J}}{0} \\
\text { N }\end{array}$ & 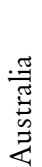 & 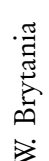 & $\cdot \frac{\pi}{0}$ & $\vec{\Xi}$ & శ్ర్ల & $\frac{0}{\pi}$ & $\begin{array}{l}\stackrel{\pi}{0} \\
\frac{\pi}{\pi} \\
0 \\
0\end{array}$ & 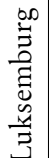 & 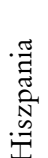 & 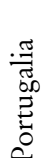 & \\
\hline
\end{tabular}




\begin{tabular}{|c|c|c|c|c|c|c|c|c|c|c|c|c|c|c|c|c|c|c|c|c|c|}
\hline 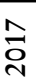 & $\begin{array}{l}\dot{t} \\
\text { gे }\end{array}$ & ڤn & 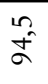 & $\begin{array}{l}\infty \\
\infty \\
\infty\end{array}$ & $\vec{\infty}$ & $\begin{array}{c}\infty \\
\tilde{\infty}^{n}\end{array}$ & $\hat{\infty}$ & $\hat{\wedge}$ & $\left|\begin{array}{l}2 \\
\hat{0} \\
0\end{array}\right|$ & & ช̂ & $\hat{\sigma}^{2}$ & $\hat{\tilde{n}}$ & $\hat{\hat{n}}$ & กิ & $\left|\begin{array}{c}0 \\
-1 \\
\text { in }\end{array}\right|$ & $\begin{array}{l}\infty \\
f^{\infty}\end{array}$ & $\mid \begin{array}{l}+ \\
\dot{f}\end{array}$ & $\hat{m}^{2}$ & 의 & $\stackrel{2}{\stackrel{f}{f}}$ \\
\hline 윰 & $\begin{array}{l}\infty \\
\hat{O}^{0} \\
0\end{array}$ & $\begin{array}{r}t_{0} \\
\sigma\end{array}$ & 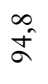 & $\begin{array}{l}\text { No } \\
\infty\end{array}$ & $\approx$ & $\begin{array}{l}\mathcal{N} \\
\stackrel{\infty}{\infty}\end{array}$ & $\hat{n}$ & $\stackrel{\sim}{\wedge}$ & \begin{tabular}{l|}
$n$ \\
$f f$ \\
\end{tabular} & $\begin{array}{l}0 \\
\hat{n} \\
0\end{array}$ & $\begin{array}{l}0 \\
\tilde{\sigma} \\
\end{array}$ & $\begin{array}{l}\text { 음 } \\
\text { in }\end{array}$ & $\begin{array}{l}n \\
0 \\
0\end{array}$ & $\stackrel{t}{\hat{n}}$ & \begin{tabular}{l|} 
\\
if \\
in
\end{tabular} & $\stackrel{m}{i n}$ & $\begin{array}{l}\hat{o} \\
\hat{f}\end{array}$ & $\begin{array}{l}+ \\
\stackrel{f}{f}\end{array}$ & $\vec{f}$ & $\hat{\text { yิ }}$ & $\frac{a}{\hat{n}}$ \\
\hline$\stackrel{n}{\circ}$ & $\stackrel{\infty}{\stackrel{\infty}{\Xi}}$ & $\stackrel{+}{a}$ & $\stackrel{\sim}{2}$ & ஜ̂ & $\begin{array}{l}\circ \\
\stackrel{\circ}{ }\end{array}$ & $\begin{array}{l}\infty \\
\hat{\infty}^{n}\end{array}$ & $\begin{array}{l}n \\
\hat{\infty} \\
\infty\end{array}$ & $\hat{\hat{\wedge}}$ & $\begin{array}{c}0 \\
6 \\
6\end{array} \mid$ & $\begin{array}{l}\hat{\theta} \\
\hat{\theta}\end{array}$ & $\left|\begin{array}{c}\infty \\
\infty \\
\infty \\
+\end{array}\right|$ & $\hat{n}$ & $\begin{array}{l}0 \\
f \\
f\end{array} \mid$ & $\begin{array}{l}+t \\
\hat{b} \\
i n\end{array}$ & $\begin{array}{c}0 \\
\hat{n} \\
i n\end{array} \mid$ & $\begin{array}{c}\hat{q} \\
\dot{q}\end{array}$ & $\begin{array}{l}\sigma_{m} \\
\sigma^{\prime}\end{array}$ & $\hat{n}$ & $\begin{array}{l}\infty \\
n \\
m\end{array}$ & $\stackrel{n}{f}$ & $\begin{array}{l}\sigma_{\hat{\sigma}} \\
\end{array}$ \\
\hline$\stackrel{ \pm}{\stackrel{D}{N}}$ & $\stackrel{\cong}{\varrho}$ & $\begin{array}{l}\infty \\
\hat{\sigma}\end{array}$ & $\stackrel{0}{\hat{\sigma}}$ & $\stackrel{2}{\hat{\sigma}}$ & $\hat{\hat{a}}$ & $\begin{array}{l}0 \\
\stackrel{\infty}{\infty}\end{array}$ & $\begin{array}{l}a \\
\infty \hat{0} \\
\infty\end{array}$ & $\stackrel{n}{\Omega}$ & $\begin{array}{c}2 \\
0 \\
n\end{array}$ & $\begin{array}{l}n \\
\hat{\theta}\end{array}$ & $\mid \begin{array}{c}+ \\
\stackrel{n}{\Rightarrow}\end{array}$ & $\begin{array}{l}\infty \\
\hat{q} \\
\hat{q}\end{array}$ & $\overrightarrow{\hat{o}_{0}^{0}}$ & $\hat{n}^{n}$ & $\begin{array}{l}\hat{2} \\
\hat{i}\end{array}$ & $\begin{array}{l}\infty \\
\sigma^{n}\end{array}$ & \begin{tabular}{l}
$n$ \\
\multirow{n}{n}{} \\
$\hat{n}^{2}$
\end{tabular} & $\mid \begin{array}{l}\infty \\
0 \\
\infty\end{array}$ & $\hat{\tilde{y}}$ & $\begin{array}{l}\infty \\
\text { ó }\end{array}$ & $\mid \begin{array}{c}1 \\
\infty \\
0 \\
0\end{array}$ \\
\hline$\stackrel{m}{\stackrel{2}{d}}$ & $\overrightarrow{\infty^{\prime}}$ & $\begin{array}{l}\hat{0} \\
\hat{0}\end{array}$ & $\stackrel{t}{\sigma}$ & $\stackrel{\cong}{\Xi}$ & $\hat{\sigma}$ & $\begin{array}{l}0 \\
\stackrel{i}{a}\end{array}$ & $\hat{\sigma}$ & $\hat{\vec{\infty}}$ & $\begin{array}{l}10 \\
\text { no } \\
\text { in }\end{array}$ & $\begin{array}{l}0 \\
\text { fo } \\
0\end{array}$ & $\begin{array}{l}\overrightarrow{1} \\
\text { in }\end{array}$ & $\begin{array}{l}0 \\
\infty \\
\infty \\
+\end{array}$ & $\begin{array}{c}0 \\
\hat{\sigma}\end{array}$ & $\frac{\sigma}{\hat{f}}$ & $\vec{m}$ & $\frac{r}{5}$ & $\begin{array}{l}\hat{0} \\
\hat{b}\end{array}$ & $\begin{array}{c}\hat{\sigma} \\
\hat{\sigma}\end{array}$ & $\begin{array}{l}\mathcal{y} \\
\text { fo }\end{array}$ & $\vec{f}$ & $\begin{array}{l}t \\
\hat{\sigma}\end{array}$ \\
\hline$\stackrel{7}{\stackrel{7}{2}}$ & $\begin{array}{l}\infty \\
\mathfrak{0}^{-} \\
=\end{array}$ & $\begin{array}{l}\infty \\
\infty \\
0 \\
0\end{array}$ & $\hat{\hat{a}}$ & $\begin{array}{l}0 \\
\stackrel{\vec{I}}{I}\end{array}$ & $\hat{\sigma}$ & \begin{tabular}{l} 
I \\
\multirow{2}{*}{}
\end{tabular} & $\begin{array}{l}+ \\
\dot{a}\end{array}$ & $\stackrel{+}{\hat{\infty}}$ & $\left|\begin{array}{c}0 \\
1 \\
i n\end{array}\right|$ & $\hat{\hat{\sigma}}$ & $\left|\begin{array}{l}\infty \\
\hat{f}\end{array}\right|$ & $\begin{array}{l}\infty \\
0 \\
f \\
f\end{array}$ & $\hat{\hat{\sigma}}$ & $\begin{array}{c}\hat{\sigma} \\
\hat{f}\end{array}$ & $\overrightarrow{0}$ & $\left|\begin{array}{l}\infty \\
\sigma^{n}\end{array}\right|$ & $\hat{\sigma}^{\prime}$ & $\stackrel{2}{=}$ & $\hat{\hat{n}}$ & \begin{tabular}{l}
0 \\
ô \\
\multirow{1}{*}{}
\end{tabular} & \begin{tabular}{|c}
$\infty$ \\
$i$ \\
$i$
\end{tabular} \\
\hline $\bar{\nabla}$ & $\stackrel{\cong}{\cong}$ & $\stackrel{0}{=}$ & $\hat{\sigma}^{2}$ & 高 & $\hat{\hat{\theta}}$ & $\overrightarrow{0}$ & $\begin{array}{l}\hat{\alpha} \\
\hat{\sigma}\end{array}$ & $\begin{array}{l}0 \\
\dot{+} \\
\infty\end{array}$ & $\begin{array}{c}0 \\
\text { in } \\
\text { nn }\end{array} \mid$ & $\begin{array}{l}0 \\
\hat{\sigma}^{\prime}\end{array}$ & $\left|\begin{array}{c}0 \\
0 \\
\infty\end{array}\right|$ & $\begin{array}{l}\hat{f} \\
\hat{f}\end{array}$ & $\overrightarrow{0}$ & $\begin{array}{l}0 \\
\vec{f}\end{array}$ & $\underset{\text { in }}{ \pm}$ & $\mid \begin{array}{c}\hat{0} \\
\infty \\
\dot{+}\end{array}$ & $\mid \begin{array}{c}\tilde{N} \\
\tilde{\infty}\end{array}$ & $\begin{array}{l}n \\
\stackrel{n}{=} \\
=\end{array}$ & $\begin{array}{l}\infty \\
\infty \\
i n\end{array}$ & $\begin{array}{l}0 \\
\stackrel{a}{q}\end{array}$ & $\overrightarrow{0^{0}}$ \\
\hline 응 & $\stackrel{0}{=}$ & $\stackrel{+}{\stackrel{ \pm}{\Xi}}$ & $\begin{array}{l}0 \\
\infty \\
\infty \\
\infty\end{array}$ & \begin{tabular}{l}
$a$ \\
\multirow{f}{0}{} \\
$\sigma$
\end{tabular} & $\stackrel{+}{\hat{O}}$ & $\begin{array}{l}n \\
\infty^{\prime}\end{array}$ & $\dot{\sigma}$ & $\begin{array}{l}0 \\
\infty \\
\infty \\
\infty\end{array}$ & $\left|\begin{array}{l}10 \\
0 \\
0 \\
10\end{array}\right|$ & $\begin{array}{l}\hat{0} \\
\hat{0}\end{array}$ & $\begin{array}{l}n \\
\hat{\alpha} \\
\alpha\end{array}$ & $\overrightarrow{f^{n}}$ & 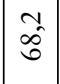 & $\begin{array}{l}\infty \\
i \\
f\end{array}$ & $\begin{array}{c}\hat{\hat{o}} \\
\hat{\sigma}\end{array}$ & $\begin{array}{l}\hat{\gamma} \\
\hat{f}\end{array}$ & $\stackrel{2}{2}$ & $\begin{array}{c}\tilde{n} \\
\tilde{n}\end{array}$ & $\begin{array}{l}\infty \\
0 \hat{0}\end{array}$ & $\begin{array}{l}\text { O) } \\
\text { in }\end{array}$ & $\begin{array}{l}0 \\
\hat{\sigma}\end{array}$ \\
\hline ठ̀े & $\begin{array}{l}0 \\
\infty \\
\infty \\
\infty\end{array}$ & $\stackrel{2}{\cong}$ & $\begin{array}{l}0 \\
\stackrel{\infty}{0}\end{array}$ & $\stackrel{+}{\stackrel{t}{\Omega}}$ & $\overrightarrow{0}$ & $\hat{\hat{\alpha}}$ & $\begin{array}{l}\infty \\
\hat{\infty} \\
\infty\end{array}$ & त̂ & $\begin{array}{c}n \\
0 \\
\infty \\
\text { in }\end{array}$ & $\begin{array}{l}0 \\
\hat{\sigma}\end{array}$ & & $\begin{array}{l}\sigma_{f} \\
f \\
f\end{array}$ & $\hat{\hat{b}}$ & $\stackrel{m}{f}^{2}$ & $\begin{array}{l}0 \\
\stackrel{9}{f}\end{array}$ & $\begin{array}{c}m \\
i f\end{array}$ & $\begin{array}{c}m \\
\infty \\
\infty\end{array}$ & $\begin{array}{l}\hat{x} \\
\hat{0} \\
-1\end{array}$ & $\begin{array}{l}0 \\
8 \\
0\end{array}$ & & $\stackrel{2}{-0}$ \\
\hline 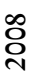 & $\begin{array}{l}2 \\
\infty \\
\infty\end{array}$ & $\begin{array}{l}\stackrel{0}{0} \\
\stackrel{n}{=}\end{array}$ & $\begin{array}{l}m \\
\hat{\infty}\end{array}$ & $\begin{array}{l}\stackrel{+}{2} \\
\stackrel{2}{\approx}\end{array}$ & $\stackrel{n}{\hat{\sigma}}$ & $\begin{array}{l}\infty \\
\hat{n} \\
\hat{\sigma}\end{array}$ & $\begin{array}{l}0 \\
+ \\
\infty\end{array}$ & 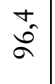 & $\begin{array}{l}2 \\
\hat{i}\end{array}$ & $\hat{\hat{R}}$ & & $\hat{\hat{q}}$ & $\begin{array}{c}\hat{\sigma} \\
\hat{\sigma}\end{array}$ & $\begin{array}{l}0 \\
\stackrel{f}{f}\end{array}$ & 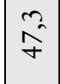 & $\begin{array}{c}+ \\
\dot{f}\end{array}$ & $\underbrace{t}$ & $\mid \begin{array}{c}a \\
\hat{\sigma} \\
0\end{array}$ & $\begin{array}{l}\dot{ } \\
\stackrel{n}{n}\end{array}$ & & $\mid \begin{array}{l}1 \\
8 \\
\Omega\end{array}$ \\
\hline ठ̀. & \begin{tabular}{l}
$n$ \\
\multirow{\infty}{*}{}
\end{tabular} & $\stackrel{O}{\Xi}$ & กู & $\begin{array}{l}\text { ñ } \\
\hat{o n} \\
\text { in }\end{array}$ & $\hat{\tilde{0}}$ & $\hat{\sigma}$ & $\overrightarrow{\tilde{N}}$ & $\begin{array}{l}0 \\
\stackrel{0}{\circ}\end{array}$ & $\begin{array}{c}1 \\
\hat{0} \\
0\end{array}$ & $\hat{\sigma}$ & & $\stackrel{+}{\stackrel{m}{m}}$ & $\frac{n}{6}$ & $\begin{array}{c}\infty \\
\stackrel{m}{m}\end{array}$ & $\overrightarrow{\hat{n}}$ & $\begin{array}{c}\sigma \\
\infty \\
\infty\end{array}$ & $\begin{array}{l}\hat{\sigma} \\
\hat{R}\end{array}$ & $\begin{array}{l}0 \\
0 \\
i n \\
n\end{array}$ & $\hat{n}$ & & \begin{tabular}{|l|}
0 \\
\multirow{5}{*}{} \\
$\infty$
\end{tabular} \\
\hline ஜั & $\hat{n}^{m}$ & $\begin{array}{l}0 \\
0 \\
0\end{array}$ & $\stackrel{n}{\wedge}$ & $\begin{array}{l}0 \\
\stackrel{i}{m}\end{array}$ & $\begin{array}{l}\infty \\
\infty \\
\infty\end{array}$ & $\begin{array}{l}+ \\
\dot{a}\end{array}$ & $\begin{array}{l}0 \\
\hat{n}\end{array}$ & $\hat{\hat{0}}$ & $\begin{array}{l}n \\
n \\
\delta \\
\delta\end{array} \mid$ & $\begin{array}{l}a \\
\stackrel{t}{n}\end{array}$ & & $\hat{m}^{\infty}$ & $\begin{array}{l}n \\
n \\
\infty \\
i n\end{array}$ & $\begin{array}{l}a \\
\hat{d}\end{array}$ & $\stackrel{\sim}{\approx}$ & \begin{tabular}{|c|}
0 \\
$f^{n}$
\end{tabular} & $\begin{array}{l}\infty \\
\sigma^{n}\end{array}$ & $\begin{array}{l}n \\
f \\
\pm \\
-1\end{array}$ & $\stackrel{+}{\stackrel{f}{f}}$ & & \begin{tabular}{|l|}
$n$ \\
$n$ \\
$n$ \\
$n$
\end{tabular} \\
\hline ஜ̊ & in & $\hat{\hat{0}}$ & $\stackrel{+}{\sigma}$ & $\underset{\vec{\sim}}{\stackrel{\vec{J}}{\vec{t}}}$ & on & \begin{tabular}{l}
2 \\
\multirow{2}{*}{}
\end{tabular} & $\frac{O_{n}}{n}$ & $\begin{array}{l}\stackrel{a}{\hat{0}} \\
\dot{\sigma}\end{array}$ & $\begin{array}{l}2 \\
\hat{\sigma}\end{array}$ & $\stackrel{2}{\wedge}$ & & & $\begin{array}{l}\sigma_{\hat{n}} \\
i n\end{array}$ & 今) & $\overrightarrow{\hat{\imath}}$ & $\begin{array}{l}+ \\
\stackrel{\sim}{v}\end{array}$ & $\overrightarrow{\hat{n}}$ & $\begin{array}{l}\mathbf{1} \\
\stackrel{ \pm}{I}\end{array}$ & $\hat{q}$ & & $\begin{array}{l}0 \\
i^{n}\end{array}$ \\
\hline 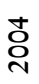 & $\hat{\tilde{\sigma}}$ & $\begin{array}{l}0 \\
\hat{\sigma}\end{array}$ & $\stackrel{\infty}{\hat{b}}$ & $\begin{array}{l}0 \\
\stackrel{2}{n}\end{array}$ & $\hat{\Omega}$ & $\begin{array}{l}\infty \\
\stackrel{n}{\infty} \\
\infty\end{array}$ & $\begin{array}{l}\hat{\sigma} \\
\hat{\sigma}\end{array}$ & $\overrightarrow{\mathrm{o}}$ & \begin{tabular}{|c|}
$n$ \\
0 \\
0
\end{tabular} & \begin{tabular}{l}
\multirow{2}{*}{} \\
$\stackrel{5}{N}$
\end{tabular} & & & $\begin{array}{l}\infty \\
\stackrel{n}{f}\end{array}$ & 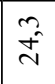 & ?ै & $\begin{array}{l}\infty \\
\stackrel{\infty}{n}\end{array}$ & $\tilde{O}^{\prime}$ & $\begin{array}{l}0 \\
\text { On } \\
0\end{array}$ & $\begin{array}{l}a \\
\infty_{\tilde{r}}\end{array}$ & & $\begin{array}{l}0 \\
0 \\
0 \\
q\end{array}$ \\
\hline O̊̀ & in & $\begin{array}{l}\dot{a} \\
\dot{\sigma}\end{array}$ & कृ & 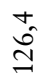 & $\stackrel{2}{\infty}$ & $\begin{array}{l}\infty \\
\stackrel{n}{\infty} \\
\infty\end{array}$ & $\begin{array}{l}n \\
n \\
n\end{array}$ & $\begin{array}{l}n^{2} \\
\stackrel{2}{O}\end{array}$ & ป̂ & $\begin{array}{l}n \\
n \\
n\end{array}$ & & & $\vec{f}$ & $\frac{N}{2}$ & $\begin{array}{l}+ \\
\stackrel{2}{二}\end{array}$ & $\begin{array}{l}+ \\
\stackrel{\sim}{v}\end{array}$ & & $\begin{array}{l}n \\
i n \\
\infty\end{array}$ & 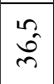 & & \\
\hline ర్ & $\hat{n}^{m}$ & ๙ે & $\begin{array}{l}n \\
\hat{n} \\
\hat{n}^{2}\end{array}$ & $\stackrel{\infty}{\hat{0}}$ & $\hat{m}_{\infty}$ & $\begin{array}{l}n \\
n \\
\infty \\
\infty \\
\infty\end{array}$ & $\hat{\tilde{\sigma}}$ & $\begin{array}{l}\hat{\sigma} \\
\stackrel{\theta}{=}\end{array}$ & $\begin{array}{l}\hat{\hat{b}} \\
\hat{\hat{b}}\end{array}$ & $\begin{array}{l}\hat{\imath} \\
\hat{\imath}\end{array}$ & & & $\stackrel{\circ}{\stackrel{f}{f}}$ & $\begin{array}{l}0 \\
\stackrel{0}{\infty}\end{array}$ & $\hat{\mathfrak{I}}$ & $\hat{\tilde{v}}$ & & $\begin{array}{c}+\dot{n} \\
\hat{n}\end{array}$ & $\begin{array}{l}m \\
\stackrel{m}{m}\end{array}$ & & \\
\hline$\overline{\mathrm{O}}$ & $\overrightarrow{0}$ & $\begin{array}{l}0 \\
\alpha \\
\alpha\end{array}$ & $\hat{\hat{n}}$ & $\stackrel{n}{\hat{N}}$ & $\begin{array}{l}3 \\
\infty \\
\infty\end{array}$ & $\hat{\hat{\infty}^{\prime}}$ & $\begin{array}{l}0 \\
\dot{\theta}\end{array}$ & $\begin{array}{l}0 \\
\mathfrak{I}\end{array}$ & $\begin{array}{l}\sigma \\
\hat{n}\end{array}$ & $\begin{array}{l}\infty \\
0 \\
\wp\end{array}$ & & & in & $\begin{array}{l}\infty \\
0^{\infty}\end{array}$ & $\stackrel{\vec{v}}{\tilde{v}}$ & $\stackrel{2}{\tilde{n}}$ & & $\frac{\sigma}{\vec{\lambda}}$ & $\begin{array}{l}0 \\
\text { in } \\
m\end{array}$ & & \\
\hline ป & $\begin{array}{l}\frac{\pi}{8} \\
\frac{0}{\tilde{U}}\end{array}$ & 岇 & 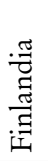 & 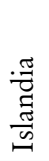 & 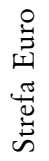 & 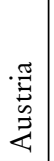 & $\begin{array}{l}\vec{\lambda} \\
\overrightarrow{0} \\
\frac{0}{3} \\
\end{array}$ & 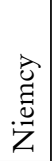 & $\mid \begin{array}{l}\cdot \frac{\pi}{00} \\
\frac{000}{00} \\
\infty\end{array}$ & $\begin{array}{l}\overline{\mathbb{N}} \\
\stackrel{\mathbb{N}}{\mathbb{N}}\end{array}$ & $\mid \begin{array}{c}\tilde{3} \\
0 \\
0 \\
+1\end{array}$ & 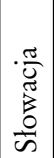 & $\mid \begin{array}{c}\frac{\pi}{0} \\
\frac{\pi}{3} \\
0 \\
\frac{\pi}{0} \\
0\end{array}$ & 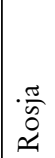 & $\frac{\pi}{\frac{\pi}{0}}$ & $\left|\begin{array}{c}\hat{\Xi} \\
\mathbb{U} \\
\mathcal{U}\end{array}\right|$ & $\mid \begin{array}{c}0 \\
\overline{0} \\
\tilde{z} \\
\frac{\tilde{n}}{n}\end{array}$ & 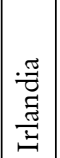 & 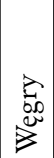 &.$\stackrel{3}{3}$ & 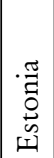 \\
\hline
\end{tabular}


a ponieważ nadmiernie rozbudowany nie służy bynajmniej wzrostowi gospodarczemu, istnieje pewna optymalna wielkość infrastruktury finansowej. Niekorzystne jest gdy jest za mała, ale także gdy jest zbyt rozrośnięta. Z jednej strony bowiem rozwój systemu finansowego pozwala uwalniać gospodarkę od różnego rodzaju ryzyka, dzięki temu, że redukuje ograniczenia finansowe i zwiększa zdolność firm i gospodarstw domowych do amortyzacji wstrząsów. Sprzyja również ich ekspansji, dostarczając kapitałów, a ponadto uwalnia konsumpcję od ograniczeń finansowych. Aby kupić jakieś kosztowniejsze dobro konsumpcyjne, nie trzeba bowiem oszczędzać, można wziąć kredyt, a to „wygładza” konsumpcję. Z drugiej zaś - finanse same z siebie generują zmienność gospodarczą i finansową oraz zwiększają prawdopodobieństwo kryzysu poprzez mobilizowanie do podejmowania większego ryzyka i korzystania z dźwigni finansowej, szczególnie gdy system finansowy jest źle uregulowany i nadzorowany.

Niby oczywiste, w gruncie rzeczy wszyscy o tym wiedza, a ostatni kryzys 2008 r. tylko potwierdził to, co ekonomiści wiedzą od dawna, ale gdy ci autorzy ponadnarodowej instytucji finansowej dochodzą do wniosku, że najbardziej optymalnej wielkości systemu finansowego dopracowała się Polska, to mam wątpliwości. Jak zauważył ostatnio W. Modzelewski, komentując rozwiązania wprowadzone przez Ministerstwo Finansów dla zwiększenia ściągalności podatku VAT (tzw. odwrotne obciążenie i podzieloną płatność (split payment)), problemem jest „atrofia, a w zasadzie brak kredytu obrotowego dla małych i średnich firm" (Modzelewski, 2018, s. 3). Autorzy szerokiej (sądząc po nazwiskach) palety narodowościowej z IMF nie wiedzą chyba, że w Polsce w transakcjach między przedsiębiorstwami słabo funkcjonuje weksel, a obligacje korporacyjne to margines systemu finansowego. Natomiast drobni i średni przedsiębiorcy boją się uzależniania od kredytów bankowych, gdyż uważają że z powodu silnej prawnej pozycji banków ich majątki mogą być łatwo przejęte, pomimo osłabienia tzw. bankowego tytułu egzekucyjnego przez przeprowadzone w poprzedniej kadencji zmiany legislacyjne i wyrok Trybunału Konstytucyjnego. Dlatego twierdzenia o takiej jakoby świetnej, optymalnej, najlepszej z punktu widzenia sprzyjania rozwojowi gospodarczemu pozycji naszego systemu finansowego są trudne do zaakceptowania.

Nie da się niestety zaprzeczyć, że dane te raczej potwierdzają słabość inwestycyjną krajów, zwłaszcza postsocjalistycznych. Co jednak istotne, wskaźnik zaangażowania kredytowego jest w zdecydowanej większości krajów wyraźnie wyższy od wskaźnika relacji oszczędności do PKB. Wysoka różnica między zaangażowaniem kredytowym a wielkością strumienia oszczędności świad- 
czy z jednej strony o sile kreacyjnej systemu finansowego, który tworzy pieniądz poprzez swą działalność kredytową. Wielkość kredytu udzielonego podmiotom prywatnym jest $\mathrm{w}$ krajach rozwiniętych o kilkadziesiąt do stu kilkudziesięciu punktów procentowych wyższa niż stopa oszczędności - i tak wyższej niż w Polsce innych krajach postsocjalistycznych. Co ciekawe, w kilku przypadkach (Polska w latach 2002-2003, Rosja na początku badanego okresu i sporadycznie niektóre inne kraje) zaangażowanie kredytowe było tak niskie, że bieżące oszczędności były wyższe od poziomu udzielonych kredytów.

Trzeba jednak mieć na uwadze to, że porównywane są tu dwie wielkości o różnym charakterze: kredyt jest wielkością zasobową mówi o ogólnym zadłużeniu kredytowym podmiotów za pomocą różnych instrumentów dłużnych o różnych okresach zapadalności, natomiast oszczędności są strumieniem oddzielonym $\mathrm{w}$ danym roku od strumienia dochodów. Są one wszak częścią wielkości strumieniowej, jaką jest PKB. Dlatego interesującym wskaźnikiem uzupełniającym obraz aktywności systemu finansowego jest wielkość stosunkowa - wielkości kredytu względem oszczędności (tab. 4).

W Polsce zaangażowanie kredytowe jest 2,5 do 3 razy wyższe od generowanych w ciągu roku oszczędności, podczas gdy w krajach rozwiniętych, jak można zauważyć w tabeli 4, przynajmniej od 4- do 10-krotnie, a nawet kilkunastokrotnie wyższe - $\mathrm{i}$ to w przypadku większości krajów rozwiniętych w stosunku do oszczędności relatywnie wyższych i w konsekwencji znacznie większego zasobu pieniądza.

Warto zauważyć, że te dane statystyczne, przecież i tak bardzo niekompletne, nie odzwierciedlają specyfiki współczesnego świata, w którym procesy ekonomiczne wychodzą poza tradycyjne mechanizmy i instytucje z nimi związane. Przykładem jest rozwój finansowania kredytów konsumenckich przez indywidualnych inwestorów i niebankowe instytucje - tzw. marketplace lending $\mathrm{z}$ wykorzystaniem platform pożyczkowych, takich jak Lending Club, które w USA w 2017 r. zrealizowały pożyczki o wartości 25,7 mld USD. Co prawda, w porównaniu z kredytem na kartach kredytowych szacowanym na ponad 1 bln USD (Kraussl, Kraussl, Pollet i Rinne, 2018) stanowi to $2,5 \%$, ale zważywszy na dynamiczny rozwój tego typu technologii uważa się, że stanowi to zagrożenie dla tradycyjnego kredytowania pożyczek konsumenckich i realizujących je instytucji pożyczkowych, podobnie jak dla rynku taksówkowego zagrożeniem jest swoisty wynalazek organizacyjny - Uber. Nasz rynek kredytowy i, ogólniej, finansowy jest zatem dalece niedostosowany do tego, co dzieje się we współczesnym świecie. 


\begin{tabular}{|c|c|c|c|c|c|c|c|c|c|c|c|c|c|c|c|c|c|c|c|}
\hline $\overrightarrow{\mathrm{d}}$ & & $\stackrel{n}{\circ}$ & $\hat{\sigma^{n}}$ & & & $\tilde{\sigma}_{\hat{\sigma}}$ & $\vec{t}_{6}^{+}$ & & $\hat{i n}$ & in & & & & $\stackrel{0}{+}$ & $\begin{array}{l}\stackrel{n}{f} \\
f\end{array}$ & $\begin{array}{l}\stackrel{+}{*} \\
\stackrel{f}{*}\end{array}$ & $\stackrel{+}{\stackrel{+}{+}}$ & $\stackrel{m}{\sim}$ & $\stackrel{\sim}{f}$ \\
\hline $\begin{array}{l}0 \\
\stackrel{0}{0} \\
\end{array}$ & $\begin{array}{l}0 \\
\stackrel{0}{0}\end{array}$ & $\stackrel{\infty}{=}$ & $\begin{array}{l}\infty \\
0^{\prime}\end{array}$ & & $\hat{\sigma}_{0}^{0}$ & $\hat{\sigma}$ & $\stackrel{\forall}{N}$ & हn & $\overbrace{0}^{0}$ & $\stackrel{0}{0}$ & $\stackrel{2}{n}$ & in & & On & $\begin{array}{l}\stackrel{n}{f} \\
f\end{array}$ & $\stackrel{\sim}{f}$ & $\begin{array}{l}+ \\
+\end{array}$ & $\stackrel{+}{+}$ & $\stackrel{+}{+}$ \\
\hline$\stackrel{n}{\circ}$ & $\hat{\sigma}^{-}$ & $\cong$ & $\stackrel{\cong}{=}$ & & $\vec{t}_{\sigma}$ & $\overrightarrow{0}$ & $\tilde{\infty}^{2}$ & Ố & $\hat{\hat{n}}$ & in & 요 & $\stackrel{\infty}{+}$ & & $\begin{array}{l}i^{n} \\
i^{2}\end{array}$ & \begin{tabular}{l}
+ \\
\multirow{\leftarrow}{*}{}
\end{tabular} & $\stackrel{n}{f}$ & $\begin{array}{l}\stackrel{2}{2} \\
+\end{array}$ & $\tilde{m}$ & $\stackrel{n}{\leftarrow}$ \\
\hline 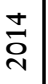 & $\begin{array}{l}\circ \\
\text { O }\end{array}$ & $\hat{\Rightarrow}$ & $\stackrel{0}{=}$ & & nీ & in & $\infty_{\infty}^{\infty}$ & $\hat{\sigma}^{0}$ & O0 & 요 & $\stackrel{\sigma}{f}$ & in & & $\hat{n}$ & $\begin{array}{l}0 \\
f^{\prime}\end{array}$ & $\begin{array}{l}\infty \\
+\end{array}$ & $\stackrel{f}{f}$ & $\stackrel{m}{m}$ & $\stackrel{\sim}{f}$ \\
\hline$\stackrel{m}{\grave{N}}$ & $\stackrel{+}{0}$ & $\vec{m}$ & $\tilde{\simeq}$ & & $\hat{\sigma}$ & in & $\stackrel{+}{\sigma}$ & $\mathfrak{\sigma}^{\infty}$ & $t_{\hat{\sigma}}^{+}$ & $\stackrel{\sigma}{\sigma}$ & $\stackrel{\sigma}{\hat{f}}$ & $\stackrel{\infty}{+}$ & & $\approx$ & $\begin{array}{l}\hat{f} \\
\hat{f}^{\prime}\end{array}$ & $\stackrel{\sigma}{f}$ & $\begin{array}{l}\infty \\
+ \\
+\end{array}$ & $m^{2}$ & in \\
\hline 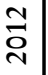 & 응 & $\stackrel{\infty}{=}$ & $\hat{\vec{g}}$ & & $\tilde{\sigma}_{0}^{0}$ & $\begin{array}{l}\text { On } \\
\text { in }\end{array}$ & $\stackrel{ \pm}{=}$ & $\hat{\sigma}^{\infty}$ & $\vec{n}$ & $\stackrel{\hat{f}}{ }$ & $\stackrel{\hat{f}}{\hat{f}}$ & $\hat{\sigma}$ & & $\begin{array}{l}0 \\
\infty\end{array}$ & $\hat{f}$ & $\stackrel{n}{f}$ & $\begin{array}{l}0 \\
+\end{array}$ & m & थे \\
\hline $\overrightarrow{\bar{D}}$ & $\Rightarrow$ & $\begin{array}{l}\infty \\
\mathfrak{I}\end{array}$ & $\overrightarrow{ \pm}$ & & 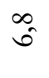 & in & $\stackrel{?}{\simeq}$ & $\mathfrak{b}^{0}$ & $\Re$ & $\stackrel{+}{+}$ & $\tilde{f}$ & $\stackrel{0}{+}$ & & $\hat{\infty}_{\hat{\infty}}$ & $\begin{array}{l}+ \\
+ \\
+\end{array}$ & $\stackrel{\circ}{\circ}$ & $\stackrel{2}{f}$ & $\stackrel{m}{m}$ & ำ \\
\hline$\stackrel{\text { 을 }}{\stackrel{2}{2}}$ & 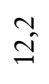 & $\stackrel{\sigma}{ \pm}$ & $\begin{array}{c}0 \\
\stackrel{0}{v}\end{array}$ & के & $N$ & $\begin{array}{l}\infty \\
\text { in }\end{array}$ & $\vec{n}$ & $\stackrel{t}{\sigma}$ & $\stackrel{\infty}{n}$ & $\stackrel{\circ}{\leftarrow}$ & $\stackrel{\sigma}{\sigma}$ & $\vec{f}$ & & $\hat{\infty^{\prime}}$ & $\begin{array}{l}0 \\
+ \\
+\end{array}$ & $\vec{m}$ & $\stackrel{\sim}{\leftarrow}$ & $\stackrel{n}{m}$ & $\begin{array}{l}0 \\
\text { in }\end{array}$ \\
\hline ઠ્રે & $\stackrel{\sim}{2}$ & $\stackrel{\infty}{\stackrel{\infty}{=}}$ & $\begin{array}{l}\infty \\
\pm \\
\pm\end{array}$ & $\stackrel{\infty}{\wedge}$ & $\hat{\hat{n}^{2}}$ & $\vec{n}$ & $\begin{array}{l}n \\
\stackrel{n}{n}\end{array}$ & જે & $\hat{\sigma}_{\hat{\infty}}$ & $\stackrel{n}{f}$ & $\stackrel{t}{n}$ & $\hat{\tilde{f}}$ & & $\begin{array}{l}n \\
\infty \\
\infty\end{array}$ & $\begin{array}{l}0 \\
+ \\
f\end{array}$ & $\stackrel{2}{n}$ & $\begin{array}{l}\stackrel{2}{2} \\
f\end{array}$ & $\stackrel{0}{m}$ & O̊ \\
\hline 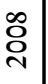 & $\stackrel{0}{\mathfrak{I}}$ & $\begin{array}{l}\infty \\
\pm\end{array}$ & $\begin{array}{l}\infty \\
\infty \\
\infty\end{array}$ & ๙2 & $\hat{\sigma}$ & $\begin{array}{l}0 \\
\text { in }\end{array}$ & $\stackrel{+}{ \pm}$ & हn & $\vec{n}$ & $\stackrel{+}{\leftarrow}$ & $\tilde{f}$ & in & $\vec{n}$ & $\overbrace{\infty}^{2}$ & $\hat{m}$ & $\vec{m}$ & $\stackrel{0}{n}$ & $\hat{\mathrm{i}}$ & $\hat{n}$ \\
\hline ڤ્̀ & $\stackrel{\infty}{=}$ & $\exists$ & to & $\tilde{n}$ & $\tilde{n}^{n}$ & $\hat{n}$ & $\Rightarrow$ & $\begin{array}{l}n \\
n\end{array}$ & $\hat{\sigma}_{\hat{0}}$ & $\stackrel{m}{m}$ & $\hat{f}$ & $\begin{array}{l}\stackrel{0}{f} \\
F^{5}\end{array}$ & $\vec{n}$ & $\hat{\varkappa^{2}}$ & $\hat{m}$ & $\tilde{v}$ & $\stackrel{m}{m}$ & $\hat{i}$ & $\stackrel{\infty}{+}$ \\
\hline 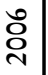 & ชู & $\begin{array}{l}\dot{t}_{0} \\
\stackrel{0}{ }\end{array}$ & $\begin{array}{l}\text { On } \\
\text { in }\end{array}$ & $\stackrel{0}{N}$ & $\dot{\theta}_{0}$ & in & $\underline{\hat{\theta}}$ & हि & $\overrightarrow{0}$ & $\vec{m}$ & $\stackrel{\infty}{+}$ & $\hat{m}$ & $\hat{n}$ & $\stackrel{\circ}{\wedge}$ & $\begin{array}{c}0 \\
m\end{array}$ & $\stackrel{\tilde{v}}{\mathrm{i}}$ & $\begin{array}{l}y \\
m\end{array}$ & $\stackrel{+}{i}$ & $\stackrel{\sim}{\digamma}$ \\
\hline$\stackrel{\text { ¿̊ }}{\mathrm{O}}$ & $\stackrel{+}{0}$ & $\tilde{a}$ & $\begin{array}{l}0 \\
\stackrel{f}{*}\end{array}$ & $\begin{array}{l}\infty \\
0 \\
0\end{array}$ & $\vec{t}_{\hat{\sigma}}$ & in & $\tilde{\sigma}$ & Ố & $\overbrace{0}^{0}$ & $\stackrel{m}{m}$ & $\stackrel{\sigma}{f}$ & $\stackrel{\circ}{\circ}$ & $\vec{n}$ & $0_{0}^{0}$ & $\begin{array}{l}n \\
m\end{array}$ & $\stackrel{\infty}{\rightarrow}$ & $\stackrel{t}{m}$ & $\begin{array}{l}\infty \\
i\end{array}$ & $\stackrel{\sim}{\sigma}$ \\
\hline ষ্ণ & $\stackrel{+}{0}$ & ñ & $\stackrel{0}{m}$ & in & $\overbrace{}^{2}$ & $\begin{array}{l}\infty \\
+ \\
f\end{array}$ & $\stackrel{\circ}{\infty}$ & ช̂ & $\begin{array}{l}0 \\
i n\end{array}$ & $\stackrel{+}{m}$ & $\stackrel{q}{f}$ & $\vec{t}$ & $\stackrel{\circ}{n}$ & on & $\hat{m}$ & $\stackrel{\infty}{\rightarrow}$ & $\stackrel{y}{m}$ & $\vec{m}$ & $\stackrel{+}{\leftarrow}$ \\
\hline$\stackrel{\Re}{O}$ & $\overrightarrow{0}$ & $\stackrel{n}{\infty}$ & $\stackrel{\sim}{m}$ & Or & $\tilde{n}^{n}$ & $\hat{f}$ & $\stackrel{n}{n}$ & $\tilde{\sigma}^{0}$ & $\begin{array}{l}n \\
i n\end{array}$ & $\hat{m}$ & in & $\vec{f}$ & $\stackrel{+}{N}$ & $\begin{array}{l}n \\
\stackrel{n}{f}\end{array}$ & $\stackrel{m}{m}$ & $\underset{i}{0}$ & $\stackrel{r}{m}$ & $\stackrel{+}{m}$ & $\stackrel{n}{+}$ \\
\hline ઠ઼ & $\begin{array}{l}\infty \\
\infty \\
\infty\end{array}$ & $\hat{\infty}$ & $\stackrel{\sim}{m}$ & $\stackrel{\sigma}{\sigma}$ & भु & $\stackrel{\sim}{f}$ & $\stackrel{\circ}{N}$ & $\mathfrak{b}^{0}$ & $\begin{array}{l}0 \\
i n\end{array}$ & $\stackrel{n}{n}$ & $\vec{n}$ & $\stackrel{n}{f}$ & $\stackrel{\infty}{n^{n}}$ & $\stackrel{2}{f}$ & $\hat{m}$ & $\underset{i}{+}$ & $\stackrel{+}{m}$ & $\vec{m}$ & $\stackrel{2}{f}$ \\
\hline$\overline{\mathrm{D}}$ & $\hat{\infty}$ & $\hat{\sigma}^{2}$ & $\hat{i}$ & $\stackrel{\sigma}{\sigma}$ & ชુ & $\stackrel{m}{\sim}$ & in & $\stackrel{+}{\sigma}$ & $\hat{n}$ & $\stackrel{n}{m}$ & $\vec{n}$ & $\stackrel{\sim}{f}$ & $\hat{n}$ & $\stackrel{\sim}{f}$ & $\tilde{m}$ & $\stackrel{+}{i}$ & $\tilde{m}$ & $\hat{i}$ & $\stackrel{m}{f}$ \\
\hline 牙 & 岕 & 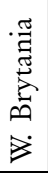 & $\begin{array}{l}\cdot \frac{\pi}{\Delta} \\
\stackrel{0}{J} \\
\end{array}$ & 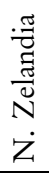 & $\underset{\text { 핑 }}{\Theta}$ & 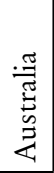 & 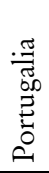 & 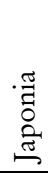 & 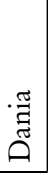 & 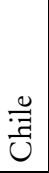 & 莺 & 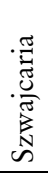 & 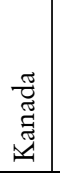 & 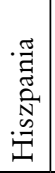 & 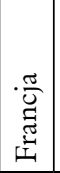 & 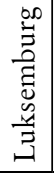 & 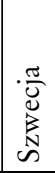 & $\begin{array}{l}\frac{\pi}{60} \\
0 \\
0 \\
0 \\
0 \\
z\end{array}$ & 딤 \\
\hline
\end{tabular}




\begin{tabular}{|c|c|c|c|c|c|c|c|c|c|c|c|c|c|c|c|c|c|c|c|c|c|}
\hline$\overline{\mathrm{N}}$ & $\vec{f}$ & $\stackrel{\circ}{f^{\prime}}$ & $\hat{m}$ & $\begin{array}{c}0 \\
m\end{array}$ & $\stackrel{n}{n}$ & $\stackrel{n}{m}$ & $\stackrel{\circ}{m}$ & $\hat{\mathrm{i}}$ & $\stackrel{\infty}{i}$ & $\hat{i}$ & & $\hat{\mathrm{i}}$ & $\begin{array}{l}0 \\
i\end{array}$ & $\stackrel{+}{i}$ & 우 & $\stackrel{\sigma}{\Rightarrow}$ & $\cong$ & 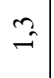 & $\stackrel{\sim}{\sim}$ & $\hat{\hat{O}^{\prime}}$ & $\overrightarrow{0}$ \\
\hline$\frac{0}{8}$ & $\stackrel{+}{+}$ & $\begin{array}{l}0 \\
\stackrel{f}{*}\end{array}$ & $\stackrel{O}{f}$ & $\begin{array}{c}\infty \\
m\end{array}$ & $\stackrel{n}{m}$ & $\stackrel{+}{m}$ & $\tilde{m}$ & m. & $\begin{array}{l}\infty \\
i\end{array}$ & $\stackrel{n}{i}$ & $\hat{i}$ & $\hat{\mathrm{i}}$ & $\begin{array}{l}\infty \\
i\end{array}$ & $\hat{i}$ & त̂ & 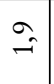 & 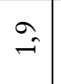 & $\stackrel{n}{=}$ & $\stackrel{2}{-}$ & $\begin{array}{l}0 \\
i\end{array}$ & $\begin{array}{l}\infty \\
i\end{array}$ \\
\hline$\frac{n}{8}$ & $\stackrel{\curvearrowright}{\sim}$ & $\stackrel{\sim}{*}$ & $\begin{array}{l}O \\
+\end{array}$ & $\dot{m}$ & $\stackrel{\circ}{+}$ & $\tilde{m}$ & $m^{2}$ & $\tilde{i}$ & $\stackrel{\infty}{\infty}$ & $\stackrel{+}{i}$ & $\hat{i}$ & $\hat{i}$ & $\hat{\mathrm{i}}$ & $\begin{array}{l}0 \\
i\end{array}$ & $\vec{i}$ & $\stackrel{\infty}{\rightarrow}$ & $\vec{i}$ & $\stackrel{n}{\rightarrow}$ & $\approx$ & $\vec{v}$ & $\begin{array}{l}0 \\
i\end{array}$ \\
\hline 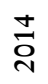 & $\stackrel{\sim}{f}$ & $\tilde{f}^{2}$ & $\stackrel{2}{+}$ & $\vec{f}$ & $\begin{array}{l}\infty \\
+\end{array}$ & $\stackrel{\infty}{i}$ & $\stackrel{+}{m}$ & $\stackrel{+}{i}$ & $\hat{\mathrm{i}}$ & $\tilde{u}$ & $\stackrel{\infty}{i}$ & $\stackrel{\sim}{i}$ & $\hat{i}$ & $m^{2}$ & $\vec{i}$ & $\stackrel{\circ}{i}$ & $\tilde{i}$ & $\stackrel{\infty}{\rightarrow}$ & $\stackrel{+}{m}$ & $\stackrel{\infty}{\rightarrow}$ & $\stackrel{n}{i}$ \\
\hline$\stackrel{m}{i}$ & $\vec{n}$ & $\hat{f}$ & $\vec{f}$ & $\begin{array}{l}+ \\
+\end{array}$ & $\stackrel{2}{n}$ & $\hat{\mathrm{i}}$ & $\stackrel{0}{n}$ & $\stackrel{0}{i}$ & $\vec{m}$ & $\tilde{v}$ & $\hat{\mathrm{i}}$ & $\stackrel{+}{i}$ & $\hat{i}$ & $\stackrel{+}{m}$ & 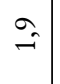 & $\vec{i}$ & $\hat{i}$ & $\approx$ & $\begin{array}{l}\infty \\
+\end{array}$ & $\vec{i}$ & $\stackrel{n}{i}$ \\
\hline 공 & $\underset{n}{\dot{n}_{n}}$ & $\begin{array}{l}+ \\
\leftarrow\end{array}$ & $\stackrel{\circ}{\circ}$ & $\begin{array}{l}n \\
f\end{array}$ & $\begin{array}{l}n \\
0 \\
0\end{array}$ & $\underset{i}{i}$ & $\stackrel{0}{n}$ & $\hat{\imath}$ & $\stackrel{\sim}{m}$ & $\tilde{v}$ & $\vec{m}$ & $\tilde{v}$ & $\hat{i}$ & $n_{n}^{n}$ & $\stackrel{0}{\sim}$ & $\vec{i}$ & $\hat{m}$ & $\stackrel{+}{i}$ & $\begin{array}{l}0 \\
0\end{array}$ & $\underset{\sim}{0}$ & $\hat{i}$ \\
\hline $\overrightarrow{\bar{d}}$ & $\begin{array}{c}\dot{+} \\
\dot{n}\end{array}$ & $\vec{f}$ & $\stackrel{m}{m}$ & $\begin{array}{l}0 \\
f\end{array}$ & $\begin{array}{l} \pm \\
\pm\end{array}$ & $\stackrel{n}{i}$ & $\hat{m}$ & $\stackrel{n}{n}$ & $\vec{m}$ & $\stackrel{+}{v}$ & $\stackrel{\circ}{m}$ & $\hat{v}$ & $\hat{\mathrm{i}}$ & $\stackrel{n}{n}$ & $\stackrel{ \pm}{\leftrightarrows}$ & $\vec{i}$ & $\begin{array}{c}0 \\
m\end{array} \mid$ & $\begin{array}{l}\infty \\
i\end{array}$ & $\begin{array}{l}\infty \\
\hat{0}\end{array}$ & $\overrightarrow{\hat{i}}$ & $\hat{i}$ \\
\hline 음 & $\begin{array}{l}n \\
\text { in }\end{array}$ & $\stackrel{\infty}{m}$ & $\vec{f}$ & $\begin{array}{l}\infty \\
+\end{array}$ & $\stackrel{?}{ \pm}$ & $\stackrel{n}{\sim}$ & $\stackrel{\infty}{m}$ & $\stackrel{n}{f}$ & $\stackrel{n}{m}$ & $\hat{\imath}$ & $\vec{m}$ & $\tilde{v}$ & $\stackrel{\circ}{m}$ & $\stackrel{m}{m}$ & $\stackrel{0}{=}$ & $\vec{i}$ & $\begin{array}{c}\infty \\
m\end{array}$ & m & $\begin{array}{l}0 \\
\infty\end{array}$ & $\stackrel{n}{m}$ & $\begin{array}{l}0 \\
f\end{array}$ \\
\hline ठ্ণ & On & $\hat{m}$ & $\stackrel{+}{\leftarrow}$ & $\vec{n}$ & $\begin{array}{l}\infty \\
\hat{\delta} \\
\hat{n}\end{array}$ & $\stackrel{+}{i}$ & $\stackrel{m}{m}$ & & $\vec{t}$ & $\begin{array}{l}0 \\
\hat{v}\end{array}$ & $\vec{m}$ & $\begin{array}{l}0 \\
i\end{array}$ & $\begin{array}{l}\infty \\
i\end{array}$ & $\stackrel{m}{m}$ & $\stackrel{0}{i}$ & $\stackrel{\circ}{i}$ & $\begin{array}{c}0 \\
m\end{array} \mid$ & $\vec{m}$ & $\hat{2}$ & & $\stackrel{?}{f}$ \\
\hline 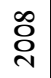 & $\begin{array}{l}+ \\
\dot{f}\end{array}$ & $\hat{\mathrm{i}}$ & $\vec{f}$ & $\begin{array}{l}n \\
f\end{array}$ & $\hat{\tilde{J}}$ & $\stackrel{\sigma}{\rightarrow}$ & $\stackrel{m}{m}$ & & $\stackrel{0}{m}$ & $\stackrel{\infty}{\rightarrow}$ & $\stackrel{m}{m}$ & $\hat{\imath}$ & $\begin{array}{l}0 \\
i\end{array}$ & $\begin{array}{l}\infty \\
i \\
i\end{array}$ & $\cong$ & 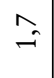 & $\begin{array}{l}\infty \\
i\end{array}$ & $\stackrel{+}{m}$ & $\hat{\hat{\infty}}$ & & $\vec{f}$ \\
\hline Ò̀ & ले & $\begin{array}{l}0 \\
i \\
i\end{array}$ & $\vec{m}$ & $\vec{f}$ & $\stackrel{a}{\hat{n}}$ & $\vec{i}$ & $\stackrel{m}{m}$ & & $\stackrel{n}{n}$ & $\stackrel{0}{\rightarrow}$ & $\stackrel{\infty}{i}$ & $\stackrel{+}{i}$ & 온 & $\hat{\mathrm{i}}$ & $\stackrel{2}{\sim}$ & $\stackrel{ \pm}{\rightarrow}$ & in & $\tilde{m}^{2}$ & $\hat{\sigma}$ & & $n^{n}$ \\
\hline ठั & $\hat{m}$ & $\begin{array}{l}0 \\
i \\
i\end{array}$ & $\vec{m}$ & $\stackrel{\tau}{f}$ & 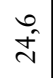 & $\tilde{v}$ & $\stackrel{0}{n}$ & & $\stackrel{\circ}{+}$ & $\stackrel{0}{\rightarrow}$ & $\stackrel{\circ}{m}$ & $\stackrel{+}{\sim}$ & $\stackrel{\infty}{\rightarrow}$ & $\begin{array}{l}n \\
i\end{array}$ & $\stackrel{0}{\rightarrow}$ & $\stackrel{2}{-}$ & $\vec{i}$ & $\begin{array}{l}0 \\
i\end{array}$ & $\begin{array}{l}2 \\
n\end{array}$ & & $\vec{m}$ \\
\hline 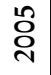 & $\stackrel{m}{m}$ & $\stackrel{\sim}{\sim}$ & $\stackrel{2}{f}$ & $\Rightarrow$ & $\begin{array}{l}0 \\
\infty \\
\rightarrow\end{array}$ & $\stackrel{+}{i}$ & $\begin{array}{l}0 \\
n\end{array}$ & & $\stackrel{n}{\stackrel{n}{f}}$ & & $\stackrel{n}{m}$ & $\stackrel{+}{i}$ & $\stackrel{0}{\rightarrow}$ & $\hat{\mathrm{v}}$ & $\stackrel{\infty}{0}$ & $\Rightarrow$ & $\stackrel{\sigma}{\approx}$ & $\begin{array}{l}0 \\
i\end{array}$ & $\begin{array}{l}n \\
f\end{array}$ & & $\stackrel{2}{i}$ \\
\hline ¿্ণ & $\stackrel{m}{m}$ & $\tilde{v}$ & $\begin{array}{l}\circ \\
\stackrel{+}{*}\end{array}$ & $\hat{m}$ & $\hat{a^{2}}$ & $\underset{\sim}{\sim}$ & & & $\stackrel{n}{f}$ & & $\tilde{n}^{n}$ & $\hat{i}$ & $\stackrel{\infty}{\rightarrow}$ & $\stackrel{0}{i}$ & $\infty_{0}^{\infty}$ & $\stackrel{\circ}{\rightarrow}$ & $\begin{array}{l}0 \\
0\end{array}$ & $\stackrel{i}{i}$ & & & $\stackrel{\infty}{\sim}$ \\
\hline ¿̊̀ & $\tilde{m}$ & $\tilde{v}$ & $\begin{array}{l}\circ \\
\stackrel{*}{f}\end{array}$ & $\begin{array}{l}0 \\
f\end{array}$ & $\stackrel{O}{n}^{n}$ & $\hat{\mathrm{v}}$ & & & in & & $\stackrel{\infty}{m}$ & $\stackrel{+}{i}$ & $\stackrel{\infty}{0}$ & $\vec{i}$ & $\hat{0}$ & $\stackrel{0}{\rightarrow}$ & & $\tilde{v}$ & & & \\
\hline రั & $\hat{\mathrm{i}}$ & $\stackrel{\infty}{\rightarrow}$ & $\stackrel{\sim}{f}$ & $\begin{array}{l}\dot{m} \\
\dot{m}\end{array}$ & $\begin{array}{l}n \\
\stackrel{n}{f}\end{array}$ & in & & & $\overrightarrow{0}$ & & $\stackrel{\circ}{\circ}$ & $\stackrel{+}{i}$ & $\stackrel{\infty}{0}$ & $\vec{i}$ & $\stackrel{0}{0}$ & $\hat{\sigma}_{\hat{\sigma}}$ & & $\stackrel{\infty}{\sim}$ & & & \\
\hline$\overline{\mathrm{O}}$ & $\hat{\mathrm{i}}$ & $\hat{\approx}$ & $\vec{f}$ & $\hat{m}$ & $\begin{array}{l}0 \\
\text { in }\end{array}$ & $\hat{\mathrm{i}}$ & & & $\overrightarrow{0}$ & & $\hat{m}$ & & $\stackrel{+}{\leftrightarrows}$ & $\approx$ & 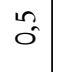 & $\cong$ & & $\stackrel{0}{\sim}$ & & & \\
\hline 牙 & 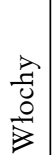 & 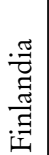 & 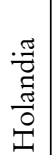 & 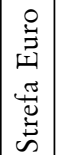 & 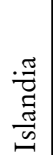 & . & 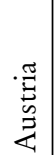 & مُ & 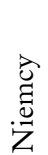 & $\begin{array}{l}\frac{\pi}{\omega} \\
\frac{\tilde{s}}{\tilde{s}} \\
\frac{0}{\omega}\end{array}$ & $\begin{array}{l}\widetilde{\Xi} \\
\stackrel{\mathbb{N}}{N}\end{array}$ & $\frac{\vec{a}}{\vec{b}}$ & $\frac{\frac{g}{4}}{0}$ & $\begin{array}{c}\cdot \frac{\pi}{0} \\
\tilde{\widetilde{s}} \\
0 \\
\frac{0}{0}\end{array}$ & $\begin{array}{l}\cdot \frac{\pi}{n} \\
0 \\
0\end{array} \mid$ & $\begin{array}{l}\hat{A} \\
\text { Uू } \\
\text { Uू }\end{array}$ & $\left|\begin{array}{c}\cdot \frac{\pi}{0} \\
\overline{0} \\
\frac{0}{0} \\
\frac{0}{\omega}\end{array}\right|$ & 竞 & 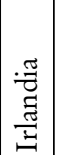 & 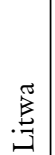 & 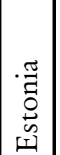 \\
\hline
\end{tabular}


Przedstawione dane wyraźnie wskazują, że system finansowy jest strukturalnie słaby, podstawową tego przyczyną jest niski poziom agregatu pieniężnego. Trzeba jednak podkreślić, że o jego wielkości decyduje wielkość zasobu oszczędności. W wyniku redukcji ich realnej wartości w 1990 r. agregat pieniężny został zredukowany z 60\% PKB do niecałych 30\% (rys. 1).

Rysunek 1. Pieniądz M2 w relacji do PKB w Polsce

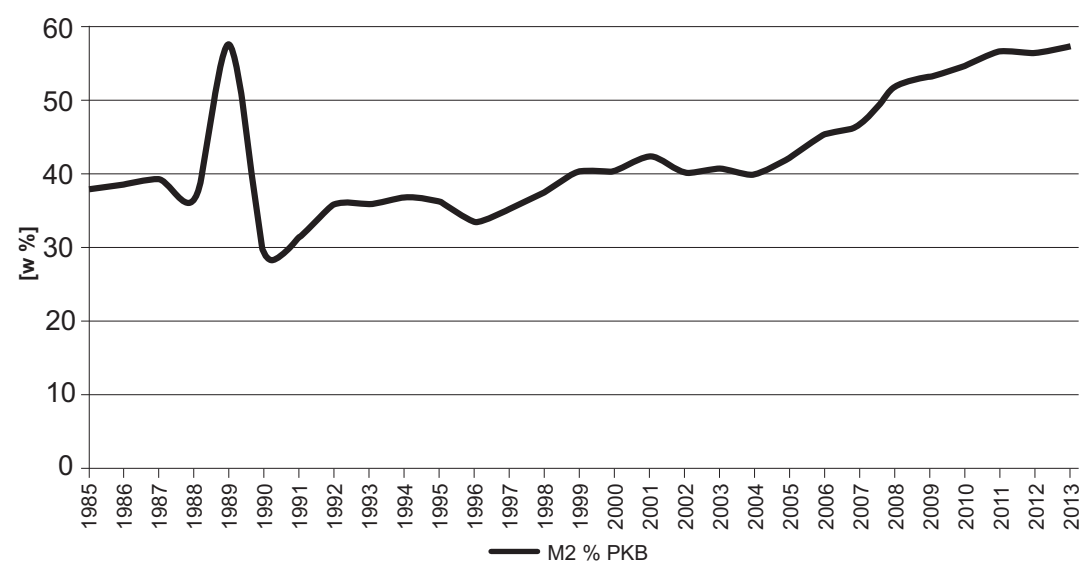

Źródło: Żyżyński, 2014.

Od 1991 roku poziom agregatu pieniężnego był stopniowo odbudowywany (Żyżyński, 2014), osiągając w 2004 r. niecałe 40\%11. Niedorozwój systemu, można powiedzieć „zintegrowany z niskim stanem zasobu pieniądza” był nie tylko efektem, lecz także doprowadził do upadku znacznej części przemysłu i ułatwił jego rabunkową prywatyzację oraz wrogie przejęcia - działały tu silne negatywne sprzężenia zwrotne.

Przyczyna niskiego poziomu zasobu pieniądza ma zatem charakter złożony i strukturalny, jest skutkiem wielu czynników, konsekwencją polityki czasu socjalizmu, gdy pieniądz odgrywał zasadniczo inną rolę w gospodarce, także błędów polityki gospodarczej początkowego okresu transformacji, ale częściowo też - i to jest kwestia, na którą warto zwrócić szczególną uwagę, jest bowiem nie tylko niedoceniana, lecz także niedostrzegana - nominalistycznego podejścia do pieniądza.

Nominalizm pieniężny - jest to pewna zasada prawna odniesiona do pieniądza, która umożliwia dłużnikowi zwolnienie się ze zobowiązania pie-

$11 \mathrm{Na}$ podstawie danych Banku Światowego. 
niężnego przez zapłatę wierzycielowi swojego długu w nominalnej wysokości, w jakiej został zaciągnięty, czyli bez uwzględniania ewentualnych zmian wartości pieniądza, które mogły zajść od momentu zaciągnięcia długu do momentu spłaty ${ }^{12}$. Zasada ta nie uwzględnia zatem zmiany siły nabywczej pieniądza, jaka zaszła pomiędzy powstaniem zobowiązania a jego wykonaniem - jest to zasada dla ekonomisty nie do zaakceptowania. Banki, stosując zasadę nominalizmu, traktują swój dług wobec deponentów nominalnie, uważają zatem, że są im winne z tytułu wniesienia do nich depozytów - tak jak każdy inny dłużnik - wartość nominalną, na którą dla skompensowania utraty wartości pieniądza nakładana jest dodatnia stopa procentowa łącząca kompensatę inflacji z realną stopą procentową. Miałaby ona być naszym „zarobkiem” za rezygnację z bieżącego wydania naszych dochodów na zaspokojenie potrzeb. Zasada ta dotyczy też kredytów i odnosi się do kapitałowej części zobowiązania kredytobiorcy. Tymczasem w latach końca ustroju socjalistycznego i pierwszych latach transformacji miał miejsce silny wzrost cen, określany jako hiperinflacja. Przypomnijmy, że w latach 1988-1991 wskaźnik wzrostu cen wyniósł kolejno 60,$2 ; 251,1 ; 585,8$ oraz $70,3 \%$, by potem stopniowo wygasać do poziomu 1,2\% w $2002 \mathrm{r}$. i po wahaniach między 1 a $4,3 \%$ osiągnąć wartość ujemną w 2015 r. Pierwsze cztery lata oznaczały zatem 65-krotne zwiększenie cen w stosunku do 1987 r. i zarazem takąż krotność spadku wartości pieniądza.

Zasada nominalizmu jest jednak ekonomicznie błędna, traktuje pieniądz tak, jakby miał on swą wewnętrzną wartość określoną przez nominał. Nie uwzględnia zatem zachowania prawa do nabywania dóbr i usług, co stanowi o istocie pieniądza. W zasadzie nominalizmu kapitał pieniężny jest w gruncie rzeczy traktowany tak, jakby pieniądz wciąż miał formę kruszcową lub był z kruszcem związany: pożyczyłes funt złota, to funt złota musisz zwrócić - gdyby to było złoto, prawo do nabywania dóbr i usług byłoby zachowane, pod warunkiem jednak, że ten funt złota miałby zachowaną siłę nabywczą.

Zdefiniowanie pieniądza jako „prawa do nabywania dóbr i usług” pozwala zrozumieć, że w gruncie rzeczy forma tego prawa nie ma znaczenia, a zasada nominalizmu oznacza złamanie tego prawa, jeśli pieniądz traci na wartości. Z zasady nominalizmu wynika bowiem postulat - skoro pożyczyłeś prawo do nabycia koszyka dóbr o określonym składzie i wartości, masz prawo oczekiwać, że twój dłużnik po określonym czasie zwróci ci prawo do nabycia tego samego koszyka - o tym samym składzie. Załóżmy na przy-

12 Wynika to z art. 358 kodeksu cywilnego. 
kład, że reprezentatywnym elementem tego koszyka jest telewizor, którego cena zmienia się w taki sam sposób jak biegnie inflacja, jeśli więc miałeś prawo do nabycia tego telewizora, to zwracający ci pożyczone pieniądze dłużnik powinien oddać ci prawo do nabycia takiego samego telewizora (pomijamy tu kwestie techniczne i tzw. zużycia moralnego czy ekonomicznego tego telewizora) oraz dodać wynagrodzenie w formie odsetek od kapitału.

Zasada nominalizmu jest $\mathrm{w}$ gruncie rzeczy bardzo wygodna i łatwa w realizacji. Zgodne $\mathrm{z}$ nią są stosowane od lat i prezentowane $\mathrm{w}$ podręcznikach wzory matematyki finansowej - kapitał ma określoną wartość nominalną, natomiast $\mathrm{w}$ przypadku stopy procentowej kwestia jej źródeł, czyli tego, w jakim stopniu uwzględnia ona inflację i część realną jest w sferze milczących założeń: stopa procentowa jest parametrem zewnętrznym. Jak jednak wykazał niżej podpisany (Żyżyński, 1988), w procesie transformacji należało jednak przyjąć zasadę waloryzacji kapitału stopą inflacj113 i dopiero na zwaloryzowany kapitał nakładać realną kilkuprocentową stopę procentową, stanowiącą (realny) dochód deponenta czy kredytodawcy. Wymagałoby to innych, zmodyfikowanych wzorów, a co więcej, zdaniem niżej podpisanego, te wzory powinny być stosowane nie tylko w procesie transformacji, lecz zawsze $\mathrm{w}$ warunkach inflacji, gdy pieniądz traci swą realną wartość - czyli przestaje być trwałym, stabilnym „prawem do nabywania dóbr i usług”. Oczywiście taka radykalna zmiana sposobu liczenia „pieniądza w czasie” wymagałaby oderwania się od tysiącletniej tradycji - raczej nie byłoby to możliwe w dzisiejszym świecie. Zresztą obecnie, gdy praktycznie nie ma inflacji, a nawet pojawia się niewielka deflacja ta kwestia straciła na znaczeniu ${ }^{14}$.

Taka zasada waloryzacyjna urealniałaby przepływy kapitału i stabilizowałaby realną wartość agregatu pieniężnego, zapobiegając jego gwałtownemu spadkowi, który bynajmniej nie powstrzymał inflacji - jej wygaszenie wymagało jeszcze całej dekady. Postulat sformułowany w tej pracy (Żyżyński, 1988)

13 Stopa inflacji odzwierciedlała wtedy zmiany cen wynikające $\mathrm{z}$ wycofywania dotacji w efekcie niektóre ceny rosły z powodu urealnienia kosztów, a niektóre nawet powstawały od zera - gdy dotowane dobro było dystrybuowane za darmo. Znaczenie pieniądza jako „prawa do nabywania dóbr i usług” nabrało jakby nowego wymiaru, pieniądz stał się nową jakością w porównaniu z tym, czym był w dobie centralnie planowanego systemu dotacji i nierynkowych (czyli niewynikających z dynamiki rynku) przepływów. W nowym systemie wynagrodzenia dawały zatem prawa do nabycia dóbr i usług, które otrzymały nowe, właściwe i prawdziwe ceny.

14 Wzory waloryzujące kapitał dla niskiej inflacji dają wyniki zbliżone do wzorów tradycyjnych, przy braku inflacji - identyczne. 
odnosił się jednak do pieniądza w obiegu, czyli agregatu pieniężnego M1, a powinno się go rozszerzyć na pieniądz M2, czyli depozytową część agregatu, którą określiłem później jako „bazę kapitałową” systemu finansowego (Żyżyński, 2014). W części kapitałowej zobowiązań powinny być bowiem realizowane i zachowane „prawa do nabywania dóbr i usług”. Pieniądz ma zachowywać nie jakąś iluzoryczną wartość kruszcu z nim związanego, lecz prawo do nabywania realnie takiej samej ilości dóbr jako części tego, co wytworzyło społeczeństwo, a sumarycznie jest ujęte jako PKB. Gdy inflacja zwiększa ceny tych dóbr, waloryzacja kapitału ma to skompensować, tak aby deponent zachował swe prawo nie dlatego, że wysoką stopa procentową dodaje mu się odsetek, ale dlatego, że urealnia się wartość kapitału, który przechowuje $\mathrm{w}$ banku.

Jak zatem powinno się było postąpić w pierwszych latach transformacji. Należało waloryzować depozyty oraz kapitałową część zobowiązań kredytobiorców. W rezultacie mielibyśmy zachowaną wartość agregatu pieniężnego w części depozytowej, nie nastąpiłby spadek podaży pieniądza, jego ilość odpowiadałaby potrzebom transformowanej na system kapitalistyczny gospodarki, w rezultacie harmonijnie rozwijałyby się instytucje rynkowego systemu finansowego, tak jak opisuje je w swej znakomitej pracy prof. Marian Górski. Kwestia ta niewątpliwie wciąż zasługuje na dogłębną dyskusję w gronie ekonomistów w kontekście analizy rynkowego systemu finansowego (Górski, 2009).

\section{Literatura}

Górski, M. (2009). Rynkowy system finansowy. Warszawa: PWE.

Kosiński, B. i Nowak, A. (2011). Podstawy wspótczesnej bankowości. Warszawa: Wydawnictwo Wydziału Zarządzania UW.

Kraussl, R., Kraussl, Z., Pollet, J. i Rinne, K. (2018). The Performance of Marketplace Lenders: Evidence from Lending Club Payment Data. 22nd International Conference on Macroeconomic Analysis and International Finance, 24-26 May, Rethymno, Greece.

Modzelewski, W. (2018). Drodzy czytelnicy. Artykuł wstępny. Doradztwo Podatkowe, Biuletym Instytutu Studiów podatkowych, 6.

Robinson, J. (1952). The Generalization of the General Theory. W: The Rate of Interest and Other Essays. London: Macmillan.

Sahay, R., Čihák, M., N’Diaye, P., Barajas, A., Bi, R., Ayala, D., Gao, Y., Kyobe, A., Nguyen, L., Saborowski, Ch., Svirydzenka, K. i Reza Yousefi, S. (2015). Rethinking Financial Deepening: Stability and Growth in Emerging Markets, IMF Staff Discussion Note, $\mathrm{SDN} / 15 / 08$, May.

Steindl, J. (1982). The Role of Household Saving in the Modern Economy. Banca Nazionale del Lavoro Quarterly Review, 140. 
Steindl, J. (1989). Saving and Debt. W: Money, Credit and Prices in Keynesian Perspective. London: Macmillan.

Toporowski, J. (2017). Kredyt i kryzys Od Marksa do Minsky'ego. Warszawa: Instytut Wydawniczy Książka i Prasa.

Żyżyński, J. (1988). Pieniadz a transformacja gospodarki (wyd. II zmienione). Warszawa: Wydawnictwo Naukowe Uniwersytetu Warszawskiego.

Żyżyński, J. (2010). Budżet i polityka podatkowa. Warszawa: PWN.

Żyżyński, J. (2014). Pieniądz egzogeniczny jako baza dla emerytur kapitałowych. W: J. Czekaj, S. Owsiak (red.), Finanse w rozwoju gospodarczym i spotecznym. Warszawa: PWE. 



\section{Upadek gospodarki PRL trzydzieści lat później. O wyobraźni ekonomistów}

Rozdziat stawia pytanie, na ile ekonomiści potrafili sformutować trafne $i$ przydatne diagnozy stanu gospodarki polskiej w stanie jej krytycznej niesprawności w końcowej dekadzie PRL? Osobiste doświadczenie autora z wczesnych lat transformacji zdobyte na krytycznym odcinku reformy wtasnościowej (prywatyzacji) oraz stworzenia regulacji i instytucji rynku kapitatowego pozwala postawić tezę, że rozwiązania transformacji miaty stabe wosparcie w diagnozach stanu wyjścia. Wyttumaczeniem może być, że ekonomiści, jak i inni nankowcy, $z$ wielkim trudem i niechęcia dopuszczaja zmianę paradygmatu - szeroko przyjętego sposobu widzenia rzeczywistości w danej dziedzinie.

Słowa kluczowe: diagnozy ekonomiczne, metodologia, paradygmat ekonomiczny, transformacja.

\section{ECONOMIC COLLAPSE OF THE PLANNED ECONOMY IN POLAND AFTER THIRTY YEARS. ON IMAGINATION OF ECONOMISTS}

In the article, a question is asked about how good economists were at formulating a true and useful diagnosis of the planned economy at its critical stage in the last decade of its existence in Poland. Personal experience of the author during the early transition years in the area of ownership reforms (privatization) and creation of institutions of capital markets from scratch allows for formulating the opinion that transition reforms had no support in a good diagnosis of the last decade of the planned economy. An explanation can be that economists, as other scientists, are deeply reluctant to accept a change of the paradigm a broadly accepted way of seeing the reality in their field.

Keywords: economic diagnostics, methodology, economic paradigm, transition.

JEL: B4, P2

* Dr hab. Grzegorz Jędrzejczak, prof. UW - Wydział Zarządzania Uniwersytetu Warszawskiego. 
Literatura przedmiotu jest usiana „malthusiańskimi” przewidywaniami na temat przyszłości gospodarki i społeczeństw, które po czasie okazały się żenująco nietrafione. Mimo nieraz bardzo dalekiego odejścia przewidywań od faktycznego przebiegu zjawisk, na ogół milcząco zakłada sie, że jest ono wynikiem niedostatku metodologii, a nie ograniczenia wyobraźni badaczy, która z kolei zależy od ich społecznego doświadczenia. To założenie naukowego pozytywizmu w jeszcze większym zakresie, niz przy przewidywaniu przyszłości, odnoszone jest do formułowania diagnoz rzeczywistości ekonomicznej. Przyjmuje się, że zła diagnoza jest wynikiem niedostatków źródłowych danych albo błędnej metodologii, a nie wynikiem niedostatków procesu „uzgodniania prawdy” w społecznym procesie uprawiania nauki (sformułowania: Th. Kuhna (1962)).

Jak starano się pokazać, z problemem tym mieliśmy do czynienia w diagnozowaniu gospodarki PRL w jej schyłkowej fazie lat 80. XX wieku.

Zbliża się trzydziesta rocznica końca niechlubnej historii PRL. W czasie tych 30 lat powstało zarówno w Polsce, jak i za granicą sporo interesujących, choć niefinalnych ocen przyczyn upadku gospodarki PRL. Są to jednak diagnozy ex post, których rezultaty najlepiej oddaje angielskie powiedzenie bindsight is always 20/20 czy nasze swojskie "mądry Polak po szkodzie". Brakuje natomiast ocen trafności diagnoz gospodarki tego okresu formułowanych w latach 80., a więc kiedy system gospodarczy PRL w sposób wyraźny chylił się ku upadkowi.

Przyczyn braku takich refleksji można się doszukiwać po pierwsze, w naturalnej niechęci do powrotu po latach do opinii i poglądów, które z dzisiejszej perspektywy mogą okazać się naiwne czy wręcz śmieszne. Po drugie, polska transformacja odniosła generalnie sukces (choć nie dla wszystkich), dlatego też zgodnie z zasadą „niesądzenia zwycięzców” uznano, że nie warto wracać do przeszłości.

Stanowisko takie wydaje mi się jednak problematyczne. Nawet jeśli po czasie diagnozy gospodarcze okazują się niepełne czy wręcz nietrafione, to jednak lekcje stąd wynikające mają olbrzymie znaczenie dla prowadzenia skutecznej polityki gospodarczej na przyszłość. Historia, wbrew oczekiwaniom niektórych, nie kończy się, a nawet przyspiesza. Co prawda można mieć uzasadnioną nadzieję, że Polska nie będzie ponownie wystawiona na tak dramatyczną próbę, jak PRL, to jednak bez wątpienia jesteśmy i będziemy wystawieni na coraz brutalniejszą konkurencję w zglobalizowanej gospodarce. Składa się na to wiele czynników, w pierwszej kolejności czynnik geopolityczny - rozszerzenie obszaru konkurencji o zasoby podażowe i popytowe ze strony krajów dotychczas niebędących istotnymi podmiotami gospodarki 
światowej. Czynnik geopolityczny jest w sposób rewolucyjny wzmacniany przez nowe technologie pozwalające na tworzenie globalnych elastycznych łańcuchów produkcji (alokacji kapitału) przy niskich kosztach transakcyjnych.

Można i trzeba postawić więc pytanie: na ile ekonomiści potrafili sformułować trafne i przydatne diagnozy stanu gospodarki polskiej w jej stanie krytycznej niesprawności końcowej dekady PRL?

Moje osobiste doświadczenie $\mathrm{z}$ wczesnych lat transformacji, zdobyte na krytycznym odcinku reformy własnościowej (prywatyzacji) oraz stworzenia regulacji i instytucji rynku kapitałowego pozwala mi postawić tezę, że rozwiązania transformacji miały słabe wsparcie $\mathrm{w}$ diagnozach stanu wyjścia, były tworzone na ogół ad hoc metodą „prób i błędów”.

Gospodarka PRL, mimo relatywnie krótkiego trwania i realizowania modelu gospodarki planowej, przechodziła dosyć zmienne koleje losu. W efekcie również produkt narodowy na osobę w porównaniu z rozwiniętymi krajami Zachodu zmieniał się dosyć istotnie.

Najwyższy wskaźnik relacji PKB per capita Polski i zachodniej Europy uzyskaliśmy w 1950 roku (Maddison Historical Statistics Project, b.d.), co było spowodowane zbiegiem dwóch niepowtarzalnych okoliczności - z jednej strony, gwałtownym spadkiem populacji Polski w wyniku wojny, przesunięciem kraju na zachód oraz bardzo intensywnym okresem powojennej odbudowy. Z drugiej zaś - relatywnie niskiej produktywności gospodarek krajów zachodu w wyniku zniszczeń wojennych. Efekt ten był jednak krótkotrwały.

Już we wczesnych latach 50. wskaźnik ten uległ znacznemu pogorszeniu $\mathrm{w}$ wyniku przyśpieszenia rozwoju Zachodu przez wprowadzenie Planu Marshalla oraz wyhamowaniu impetu odbudowy Polskiej gospodarki w miarę umacniania się komunizmu.

W efekcie złej struktury gospodarki oraz niskiej produktywności, w koncowych latach PRL, polski PKB per capita spadł do poziomu 34\% PKB per capita Zachodu. Był to jeden z najniższych poziomów tej relacji w historii. Wskazuje to na fałszywość pojawiających się poglądów o zaletach systemu realnego socjalizmu w odrabianiu opóźnień rozwojowych.

Nieskuteczność ekonomiczna PRL wygląda jeszcze gorzej w porównaniu z Koreą Południową. Jeszcze w latach 70. Polska miała PKB na głowę dwa razy wyższy niż Korea Południowa, aby już 20 lat później stanowił on tylko 60\% koreańskiego PKB per capita. Podobnie, chociaż nie tak samo dramatycznie, wygląda porównanie z Hiszpanią i Portugalią.

Ocena gospodarki to nie tylko PKB, lecz także charakterystyki strukturalne. Na tle krajów rozwiniętych, czy liderów rozwoju, Polska, w momencie upadku PRL, była krajem nienowoczesnym. Zatrudnienie w rolnictwie 
(25\%) było znacznie wyższe niż w Niemczech (4\%) czy w Hiszpanii (10\%). Warunki socjalne, teoretycznie uzasadnienie dla gospodarki socjalistycznej, również nie wyglądało dobrze. Śmiertelność dzieci poniżej 5 lat na poziomie 17 na 1000 urodzeń była znacząco wyższa niż w Niemczech (8) czy Hiszpanii (11); oczekiwany czas życia mężczyzn (66 lat) był znacząco niższy niż w Niemczech (72) czy Hiszpanii (73) (World Bank, 2014). Pełna i kompleksowa ocena stanu gospodarki musi też uwzględniać „poziom ulicy” - zjawisk dostrzegalnych w codziennym doświadczeniu gołym okiem, a więc sposobu, w jaki robimy zakupy, co jemy i pijemy, jak się ubieramy, jak wypoczywamy, jak mieszkamy, oraz w jaki sposób i jakim kosztem osiągamy te rezultaty.

Ekonomiści w swych ocenach mają tendencje do lekceważenia „oceny ulicy” jako subiektywnej i słabo mierzalnej. Jest to stanowisko zrozumiałe - jego opis wymaga odwołania do metodologii z punktu widzenia ekonomii „rozmytej”. Abstrahowanie od „oceny poziomu ulicy” pozbawia jednak diagnozę sytuacji gospodarczej możliwości zrozumienia potencjału napędzającego gospodarkę - zdolności poszczególnych uczestników gospodarki, ale i społeczeństwa jako całości, do poradzenia sobie z wyzwaniami rozwojowymi.

$\mathrm{Z}$ „poziomu ulicy” Polska końca lat 80 . XX wieku to zmory chronicznych niedoborów i kolejek oraz „załatwiania” jako podstawowego sposobu na życie. Widać to szczególnie wyraźnie w odniesieniu do obecnej sytuacji.

Ocena „poziomu ulicy” jest zwierciadłem zmian ekonomicznych zachowań. Druga wojna światowa i czas realnego socjalizmu premiowały ludzi zaradnych, zdolnych przetrwać horror wojny i radzić sobie z idiotyzmami systemu powojennego (w niezapomnianej opinii Kisiela, ustrój socjalistyczny walczył bohatersko z problemami, które sam stworzył). W Polsce, w odróżnieniu od innych krajów postsowieckich, człowiek zaradny był przypadkiem bardziej typowym niż szeroko analizowany homo sovieticus - osoba roszczeniowa i bezwolna.

Zaradność pozwalała jednostkom prosperować w realnym socjaliźmie, częstokroć w połączeniu z dalszą degradacją związków społecznych. Ograniczenia towarów zmuszały do zabiegania o wiele z nich „po znajomości”, co generalnie wzmacniało zwiazki personalne przy osłabieniu związków anonimowych, typowych dla gospodarek rynkowych. Paradoksalnie, proces ten odbywał sie przy poprawie powszechności edukacji, a więc czynnika sprzyjającego wychodzeniu poza wąską grupę rodziny i znajomych.

Ludzie zaradni stali się $\mathrm{w}$ decydującym stopniu motorem transformacji lat 90. Przyjęty zakres i praktyka reform stwarzały dostatecznie dużo przestrzeni dla idącej w miliony grupy ludzi zaradnych w tworzeniu małych firm 
i dla znaczącej poprawy swojej sytuacji materialnej. Szczególnie pionierzy działalności gospodarczej w początkowym okresie transformacji dorabiali się fortun, często nawet nieoczekiwanych przez nich samych.

Istnieje też jednak również ciemna strona polskiej zaradności - w swej istocie, mimo wielu podobieństw, nie może być ona bowiem utożsamiana z przedsiębiorczością. O ile bowiem rywalem, a jednocześnie kooperantem, przedsiębiorcy jest inny przedsiębiorca, a jego celem jest przekonanie klienta o wyższości proponowanej oferty - lepszego mixu jakości i ceny - o tyle rywalem i kooperantem czlowieka zaradnego jest władza. Władza rozumiana szeroko, od urzędnika wydającego licencje, przez urząd skarbowy, do policjanta. Dowodem tego są chociażby doroczne raporty Banku Światowego Doing Business, gdzie miejsce Polski w rankingu wynika głównie z bardzo dobrej pozycji w uzyskiwaniu kredytów, a więc usługi prywatnego sektora kierującego się kryteriami rynkowymi. W kontaktach z władzą sytuacja rysuje się znacznie gorzej. Polska znajduje się dużo dalej w rankingu, gdy rozpatrujemy jej miejsce pod kątem łatwości systemu płacenia podatków czy łatwości rozpoczęcia działalności gospodarczej.

Relatywne pogorszenie sytuacji Polski w okresie PRL w stosunku do rozwiniętych i wschodzących gospodarek miało miejsce, mimo deklarowanych ambicji i wysiłków stworzenia nowoczesnego społeczeństwa. Lista negatywów PRL, z punktu widzenia budowy nowoczesnego społeczeństwa, jest długa: blokowanie niekontrolowanych poziomych relacji współpracy, niszczenie zaufania do państwa, nagradzanie za bierność i konformizm, cynizm, blokowanie wymiany informacji z Zachodem, rekrutacja do władzy oparta na przynależności partyjnej a nie kryteriach merytorycznych. W efekcie, mimo deklaracji, społeczeństwo czasów PRL zostało w znacznej mierze ukształtowane jako przeciwieństwo społeczeństwa nowoczesnego - otwartego na wszystkie talenty, dającego szansę twórczości, przypisującego wartość różnorodności i potrafiącego zatrudnić różnorodność do twórczości, możliwości tworzenia biznesu, tolerancji ryzyka.

Postawmy pytanie, na ile ten obraz miał odbicie $w$ diagnozach końca PRL-u? Dla uniknięcia posądzenia o łatwą krytykę innych, w dalszej części pragnę dokonać „wiwisekcji” na pracy M. Górskiego i G. Jędrzejczaka wydanej 30 lat temu (Górski i Jędrzejczak, 1987).

Praca była próbą zdiagnozowania gospodarki realnego socjalizmu PRL w jej schyłkowej fazie. Metodologicznym punktem wyjścia była koncepcja twardości/miękkości budżetów podmiotów gospodarczych - gospodarstw domowych, przedsiębiorstw i państwa. Było to wykorzystanie popularnego w tym czasie podejścia proponowanego przez J. Kornaia, podejścia będącego 
próbą konstruktywnego wyjścia poza jałowe podejście marksistowskiej ekonomii politycznej socjalizmu, jednocześnie jednak odejście od dominującego w głównym nurcie ekonomii zachodniej podejścia równowagi ogólnej (Kornai, 1971; 1980).

Przyjętymi kryteriami oceny diagnostycznej były dwie właściwości gospodarki: (1) zdolności uzyskiwania stanu równowagi oraz (2) stabilności jako zdolności powrotu do stanu równowagi.

Choć podejście takie sprawia wrażenie wąsko technicznego, $\mathrm{w}$ istocie kryło się za nim głębsze pytanie o zdolność wspólistnienia w gospodarce realnego socjalizmu hierarchicznego planu, a więc istoty realnego socjalizmu, z autonomicznymi kontraktami podmiotów gospodarki, czyli istoty gospodarki rynkowej.

Centralność tego problemu dla przetrwania gospodarki socjalistycznej była znana - przynajmniej teoretycznie - od czasu dyskusji między Oskarem Lange i Ludwikiem von Misesem na temat zdolności gospodarki planowej do symulowania cen jako parametrów optymalnej alokacji w gospodarce bez rynku. O ile jednak tamta dyskusja miała wymiar czysto teoretyczny, o tyle w latach 80. problem miał już wymiar praktyczny - czy i jak możliwe jest wprowadzenie mechanizmów rynkowych bez utraty centralnej (monopolistycznej) kontroli nad decyzjami alokacyjnymi w konkretnej gospodarce i to znajdującej się w stanie głębokiego kryzysu?

Nasza analiza prowadziła do wniosku, że byłoby niezwykle trudne, jeśli nie niemożliwe, pogodzenie systemu centralnego planowania - hierarchicznego systemu alokacji ekonomicznych - z wymogami rynku czy swobodą kontraktu, w tym ustalania cen między autonomicznymi podmiotami gospodarki.

Ta trudność miała w naszym przekonaniu dwie przyczyny:

1) ryzyko utraty kontroli nad celami gospodarowania. „Ogólnie biorąc, głównym celem regulacji rynkowej jest stwarzanie takich warunków gospodarowania, w których maksymalizuje się makroekonomiczną efektywność wykorzystania zasobów czynników wytwórczych. Natomiast istotą planu jest mobilizowanie społecznych sił wytwórczych do realizacji celów społecznych i politycznych, których nie da się wyprowadzić z kryteriów formułowanych przez podmioty gospodarcze w skali mikro" (Górski i Jędrzejczak, 1987, s. 276);

2) opór podmiotów gospodarki (gospodarstwo domowe, przedsiębiorstwo, państwo) do przejścia od wypracowanych zachowań w ramach miękkich ograniczeń budżetowych realnego socjalizmu (zaradność), do operowania w ramach twardych ograniczeń gospodarki rynkowej (przedsiębiorczość). „Trudno oczekiwać, aby takie społeczne konse- 
kwencje mogły być w pełni zaakceptowane i przyswojone w społeczeństwie socjalistycznym, już bowiem w praktyce daje się zaobserwować daleko posuniętą nieufność społeczeństwa wobec reguł konkurencji rynkowej jako wyznacznika struktur społecznych. Oczekuje się wprawdzie, że konkurencja mogłaby przynieść pewne korzystne efekty ekonomiczne: likwidację kolejek, poprawę jakości wyrobów czy nawet spadek ich cen, jednocześnie jednak zdecydowanie odrzuca się inne jej skutki, jak np. ewentualność bezrobocia czy zróżnicowanie płac za ten sam rodzaj pracy. Przyczyn tej dwoistości postaw należy się doszukiwać w przewadze skłonności do solidaryzmu społecznego nad postawami konkurencyjnymi” (Górski i Jędrzejczak, 1987, s. 280)1․

Wnioski takie mogą wydawać się dzisiaj dosyć oczywiste, nawet z punktu widzenia pilnego studenta ekonomii, nie były one jednak tak oczywiste na początku transformacji, gdy powstało praktyczne pytanie, jak zarządzać „masą upadłościową” PRL, aby w politycznie akceptowalnym horyzoncie czasowym istotnie poprawić warunki materialne życia Polaków? Niemała grupa ekonomistów, głównie z renomowanych uczelni zachodnich, ale i polskich, argumentowała za wybraniem tzw. trzeciej drogi. Motywacje takich propozycji miały przede wszystkim charakter ideologiczny - marzenie o realizacji „prawdziwie lewicowych” idei samorządności pracowniczej, stworzenia „kapitalizmu bez kapitalistów"2. Paradoksalnie, politycy opcji postkomunistycznej bez większych problemów byli gotowi przyjąć rozwiązania prywatnej własności i kapitału. Pokolenie czterdziestolatków PZPR miało bardziej realistyczną (byli lepiej poinformowani) ocenę stopnia załamania gospodarki niż często lewicujące, lecz politycznie niedoświadczone środowiska opozycyjne. U tych ostatnich ocena zastanej rzeczywistości post-PRL-owskiej często opierała się na schemacie „tak, ale”. Przykładowo, „tak, gospodarka socjalistyczna była bardzo niewydajna, ale każdy miał pracę"3.

1 Wniosek taki, sformułowany w roku 1988, trzeba wręcz uznać za proroczy.

2 Symptomatyczne było nazwanie ministerstwa zajmującego się prywatyzacją i rynkiem kapitałowym Ministerstwem Przekształceń Własnościowych, nazwą bardziej strawną dla wielu polityków.

3 Propozycje trzeciej drogi pojawiają się również obecnie głównie pod hasłem „modelu szwedzkiego". Krytyczne oceny tzw. neoliberalnych reform okresu transformacji można spotkać z bardzo różnorodnych kierunków politycznych. Obecna sytuacja w porównaniu z okresem początku transformacji - kształtowania się systemu - jest jednak odmienna. Postulat „trzeciej drogi” musiałby „zmieścić się” w istniejącym systemie gospodarczym i politycznym. Szanse na to są $\mathrm{w}$ moim przekonaniu niewielkie, np. na uzyskanie politycznej zgody na znaczące podniesienie progresji podatkowej. 
W pracy nie sformułowano jednak dalszych wniosków o: prywatnej własności środków produkcji; rynkach kapitałowych oraz autonomicznej polityce pieniężnej jako warunkach koniecznych dla wyprowadzenia gospodarki polskiej ze strukturalnego kryzysu, w jakim się znalazła. Nie była to sytuacja w jakiś sposób szczególna; podejmowane próby zdiagnozowania gospodarki schyłku PRL i budowane propozycje na przyszłość mieściły się w nurcie reform systemu, nieraz dosyć egzotycznych, nawiązujących do jugosłowiańskiego samozarządzania czy izraelskiego kibucu.

Powstaje zatem pytanie o przyczynę braku „kropki na i” w diagnozach gospodarki schyłku PRL, które stanowiły by lepszy punkt wyjścia dla kluczowych decyzji transformacyjnych: prywatyzacji, stworzenia rynków kapitałowych, niezależnej polityki pieniężnej?

Szukając odpowiedzi na to pytanie, trzeba na wstępie odrzucić instytucjonalną niemożności krytyki systemu. Argument ten, prawdziwy do końca lat 70., w następnej dekadzie stracił racje bytu. System represji swobody badawczej „stracił zęby”, a można było wręcz wyczuć ostrożne otwarcie władz na pomysły ratujące wyraźnie walący się system gospodarki PRL. Niezależnie od intencji - strachu przed rewoltą czy też prób uwłaszczenia nomenklatury - zdemoralizowane władze komunistyczne były nawet w stanie przyjąć tzw. reformy Wilczka, de facto proponujące istotne rozszerzenie własności prywatnej. Tym samym zostało złamane tabu własności państwowej (społecznej) jako niezbywalnej cechy gospodarki socjalistycznej.

W moim przekonaniu, istotnym wytłumaczeniem było i jest instytucjonalne ograniczenie wewnątrz środowiskowe. Środowisko naukowe, nie tylko ekonomistów, z wielkim trudem i niechęcią dopuszcza zmianę paradygmatu (przyjętego sposobu widzenia rzeczywistości w danej dziedzinie), w ramach którego operuje. Jest to wynik nie tylko obrony karier, lecz także, a może przede wszystkim, znajomości i powszechności metodologii i podstawowych założeń, a więc języka, w którym grupa naukowców się porozumiewa. Konserwatyzm w obronie paradygmatu jest zjawiskiem powszechnym i ponadczasowym. Przykładowo, dzisiejsze amerykańskie uniwersytety dostarczają przykładów wręcz wynaturzonej ochrony paradygmatów nauk społecznych (paradoksalnie konserwatyzm ten jest przedstawiany jako obrona idei „progresywnych”).

Anegdotycznym przykładem na środowiskowe echo chamber - samowzmocnienie opinii środowiska - jest przypadek późniejszy, z czasu po globalnym kryzysie finansowym 2008 roku. Podczas wizyty królowej Elżbiety w London School of Economics, po briefingu na temat zaburzeń na międzynarodowych rynkach finansowych, królowa spytała „dlaczego nikt nie 
zauważył tego wcześniej?”. Niezmiernie ciekawa była odpowiedź dyrektora d/s badań departamentu zarządzania LSE: „Na każdym etapie, każdy polegał na kimś innym i w efekcie każdy myślał, że robi właściwe rzeczy” (Pierce, 2008) ${ }^{4}$. Przykład ten pokazuje, że brak dobrych diagnoz gospodarczych to nie wynik jakiejś szczególnej słabości polskich ekonomistów, ale dosyć powszechna "choroba zawodowa”.

Końcowy werdykt co do zdolności ekonomistów w budowaniu diagnoz jest $\mathrm{w}$ moim przekonaniu dosyć sceptyczny. Zdolność diagnozowania stanu rzeczywistości gospodarczej jest w sposób zasadniczy ograniczona przez konserwatywny proces „dochodzenia do prawdy”, a w środowisku ekonomistów dodatkowo narażony na wpływ poglądów „wyznawców” poszczególnych szkół ekonomicznych.

$\mathrm{Na}$ koniec trzeba stwierdzić, że powyższe uwagi nie deprecjonują w żaden sposób potrzeby wspierania różnorodności diagnozowania gospodarki, a wręcz uważam, że różnorodność jest najlepszym sposobem na wsparcie polityki gospodarczej dobrymi diagnozami. Brak różnorodności ocen, a co ważniejsze, płaszczyzn „ucywilizowanej” profesjonalnej dyskusji i osiągania konsensusu jest istotną słabością polskiego środowiska ekonomistów, a przez to i polityki gospodarczej.

\section{Literatura}

Górski, M. i Jędrzejczak, G. (1987). Równowaga i stabilność w gospodarce socjalistycznej. Warszawa: PWN.

Kornai, J. (1971). Anti-Equilibrium. Amsterdam: North-Holland Publishing Company.

Kornai, J. (1980). Economics of Shortage. Amsterdam: North-Holland Publishing Company.

Kuhn, T. (1962). The Structure of Scientific Revolutions. Chicago: The University of Chicago Press.

Maddison Historical Statistics Project. (b.d.). The Netherlands: University of Groningen. Pozyskano z: https://www.rug.nl/ggdc/historicaldevelopment/maddison/.

Pierce, A. (2008). The Queen asks why no one saw the credit crunch coming. The Telegraph, 5 November. Pozyskano z: https://www.telegraph.co.uk/news/uknews/theroyalfamily/3386353/ The-Queen-asks-why-no-one-saw-the-credit-crunch-coming.html.

World Bank. (2014). GDP per unit of energy use (constant 2011 PPP \$ per $\mathrm{kg}$ of oil equivalent). Washington, DC: OECD/IEA Statistics. Pozyskano z: http://data.worldbank.org/indicator/ EG.GDP.PUSE.KO.PP.KD? page $=4$.

${ }_{4}$ She was asking me if these things were so large how come everyone missed it. He told the Queen: At every stage, someone was relying on somebody else and everyone thought they were doing the right thing. 



\section{EWA KRAKOWIŃSKA*}

\section{Źródta finansowania podmiotów ekonomii spolecznej w Polsce}

Celem zaprezentowanej analizy jest wskazanie możliwości finansowania podmiotów ekonomii społecznej opartego na mechanizmach rynkowych. W opracowaniu omówiono gtówne źródta finansowania przedsiębiorstw spotecznych w Polsce oraz czynniki determinujace dostęp do potencjalnych źródet finansowania, a następnie na podstawie dostępnych badań $i$ opracowań GUS omówiono finansowanie przedsiębiorstw społecznych w praktyce. Dostęp do źródet finansowania jest obecnie jedna z podstawowych barier rozwoju przedsiębiorstw społecznych, możliwość wykorzystania instrumentów rynkowych w finansowaniu przedsiębiorstw spotecznych, tworzenie funduszy pożyczkowych i poręczeniowych oraz programy wsparcia na bazie instrumentów inżynierii finansowej, przyczynia sie do wzmocnienia ich kondycji finansowej $i$ większej niezależności od środków publicznych.

Słowa kluczowe: przedsiębiorstwo społeczne, finansowanie, Krajowy Program Rozwoju Ekonomii Społecznej.

\section{SOURCES OF FINANCING FOR SOCIAL ECONOMY ENTITIES IN POLAND}

The aim of the analysis is to indicate the possibility of financing social economy entities through market mechanisms. The paper discusses the main source of financing of social enterprises in Poland and the factors determining access to potential sources of funding. Furthermore, on the basis of available studies and reports prepared by the Central Statistical Office, financing of social enterprises in practice is discussed. Access to sources of financing is currently one of the main barriers to the development of social enterprises. The possibility to use market-based instruments to finance social enterprises, establish loan and credit guarantee funds and support programs on the basis of financial engineering instruments will increase their financial strength and allow their greater independence from public funds.

\footnotetext{
"Doc. dr Ewa Krakowińska - Wydział Zarządzania Uniwersytetu Warszawskiego.
} 
Keywords: social enterprise, financing, the National Program for the Development of the Social Economy.

JEL: D22

\section{Wprowadzenie}

Rośnie liczba i znaczenie przedsiębiorstw ekonomii społecznej (PES) w gospodarce. Choć obecnie powszechnie docenia się ich rolę w rozwoju społecznym i gospodarczym, to jednak teorie ekonomiczne nie potrafia w dostatecznym stopniu wyjaśnić ich istnienia i najczęściej redukują znaczenie PES do łagodzenia niedoskonałości rynku i państwa.

W teorii ekonomicznej niewiele uwagi poświęca się przedsiębiorstwom innym niż te, które są nastawione na zysk, a jeszcze mniej tym przedsiębiorstwom, które nie są zainteresowane osiąganiem czy maksymalizacją zysku i otwarcie dążą do realizacji celów społecznych.

Przedsiębiorstwa ekonomii społecznej należy zatem ulokować pomiędzy państwową a biznesową sferą gospodarowania, co wynika z łączenia celów społecznych z celami prowadzącymi do osiągnięcia zysków. Inaczej mówiąc, przedsiębiorstwa społeczne wykorzystują działalność komercyjną dla realizacji celów społecznych (Schimanek, 2015, s. 8).

Badania nad przedsiębiorstwami ekonomii społecznej w Polsce pokazały, że realizacji celów społecznych służą trzy podstawowe mechanizmy. Pierwszy z nich to integracja zawodowa i społeczna osób w trudnej sytuacji życiowej, które mają kłopoty z wejściem lub powrotem na rynek pracy, poprzez zatrudnienie ich w ramach prowadzonej działalności gospodarczej oraz objęcie wsparciem doradczym, szkoleniowym i psychologicznym (przedsiębiorstwa integracyjne). Drugi - to świadczenie w ramach działalności gospodarczej usług, które zaspokajają społeczne potrzeby, np. usługi opiekuńcze, socjalne, kulturalne, edukacyjne, w celu podniesienia jakości i poziomu życia wspólnot lokalnych. Trzeci mechanizm to przeznaczanie zysków z działalności gospodarczej na cele społecznie użyteczne, np. rehabilitację zatrudnionych osób niepełnosprawnych, a także usługi stwarzające osobom z niepełnosprawnościami niezdolnymi do podjęcia pracy możliwości rehabilitacji społecznej w zakresie przywracania umiejętności do samoobsługi, czy też stypendia dla dzieci z ubogich rodzin.

Realizacja celów społecznych, ich zakres i możliwości oddziaływania w dużej mierze zależą od ich kondycji finansowej oraz od możliwości pozyskiwania przez przedsiębiorstwa ekonomii społecznej środków na ich działalność. 
Dostęp do kapitału to jeden z najpoważniejszych problemów przedsiębiorstw ekonomii społecznej w Polsce i jedna z podstawowych barier rozwoju przedsiębiorstw. Zawarte w rozdziale rozważania mają na celu omówienie źródeł finansowania działalności przedsiębiorstw społecznych w Polsce i wskazania instrumentów finansowych wspierających rozwój przedsiębiorczości społecznej.

\section{Czynniki determinujące dostęp przedsiębiorstw ekonomii społecznej do kapitału}

Jedną z podstawowych barier rozwoju podmiotów działających w sektorze ekonomii społecznej jest dostęp do źródeł finansowania. Trudności w dostępie do kapitału wynikają ze zróżnicowania form organizacyjno-prawnych podmiotów, specyfiki ich działalności, słabości ekonomicznej, trudności z oceną wiarygodności finansowej, ryzyka związanego z prowadzoną działalnością, niskiej stabilności przychodów.

W sektorze ekonomii społecznej działają przedsiębiorstwa społeczne, których działalność gospodarcza stanowi warunek realizacji celu społecznego, podmioty reintegracyjne służące reintegracji społecznej i zawodowej osób zagrożonych wykluczeniem społecznym (Zakłady Aktywności Zawodowej - ZAZ, Warsztaty Terapii Zajęciowej - WTZ, Centra Integracji Społecznej-CIS, Kluby Integracji Społecznej - KIS). Podmioty te prowadzą działalność gospodarczą, a ich cele społeczne są realizowane w oparciu o nadwyżkę finansową. Do sektora ekonomii społecznej zalicza się również podmioty działające $\mathrm{w}$ sferze pożytku publicznego, których aktywność nie jest oparta na ryzyku ekonomicznym, prowadzą one działalność gospodarczą i zatrudniają pracowników:

- organizacje pozarządowe prowadzące działalność płatną i nieodpłatną pożytku publicznego;

- podmioty sfery gospodarczej, dla których cel społeczny jest racją bytu działalności komercyjnej lub tworzone są dla realizacji celu społecznego;

- organizacje pozarządowe;

- ZAZ prowadzące działalność gospodarczą;

- spółdzielnie socjalne;

- spółdzielnie o charakterze konsumenckim i wzajemnościowym;

- podmioty powstałe z inicjatyw o charakterze nieformalnym, np. kooperatywy spożywców, ruchy miejskie, lokatorskie i sąsiedzkie. 
Działające w sektorze ekonomii społecznej podmioty prowadzą zróżnicowaną działalność: usługi socjalne, ochrona zdrowia, edukacja, rozwój lokalny, turystyka, gastronomia, ochrona środowiska, inicjatywy obywatelskie, dlatego też trudno jest ustalić jednolite zasady pozyskiwania kapitału przez przedsiębiorstwa.

Słabość standingu ekonomicznego i niska wiarygodność wywiązania się $\mathrm{z}$ zaciągniętego zobowiązania wynikają z tego, że środki finansowe są przede wszystkim przekazywane na bieżącą realizację celów społecznych, a nie na pomnażanie majątku i maksymalizację zysku. Z punktu widzenia instytucji finansowych jako miernik oceny przedsięwzięć gospodarczych stosuje się kryterium rentowności i płynności finansowej, stosowanie tych kryteriów do przedsiębiorstw społecznych powoduje, że możliwości uzyskania wsparcia od instytucji finansowych są bardzo ograniczone.

Ocena wiarygodności finansowej przedsiębiorstw społecznych przez banki jest wykonywana według szablonów opisujących sposób i jakość zarządzania podmiotów gospodarczych, realizujących cele ekonomiczne i nie stosujących mierników oceny, które służą ocenie przedsiębiorstwa z punktu widzenia realizacji celów społecznych. W ujęciu tradycyjnej oceny, na zasoby przedsiębiorstwa składają się aktywa trwałe i obrotowe, w tym środki finansowe wyrażone wartościowo w bilansie i zestawione ze źródłami ich pochodzenia - kapitały własne i obce. W przypadku przedsiębiorstw ekonomii społecznej zasobami niebranymi pod uwagę $\mathrm{w}$ tradycyjnym bilansie i niewycenianymi, a pełniącymi funkcje kapitału są także: kapitał społeczny kształtujący podaż realizowaną przez przedsięwzięcie/przedsiębiorstwo (młodzi pracownicy, wykształceni, zaangażowani), kapitał społeczny kształtujący popyt (wizerunek organizacji, zaufanie społeczne), wolontariat i praca społeczna (Herbst, 2008, s. 9-10).

Istnieje zatem pilna potrzeba stworzenia jednolitych standardów oceny sprawności działania przedsiębiorstw ekonomii społecznej, co wymusza stosowanie odmiennego sposobu księgowości i innego zakresu publikowanych informacji finansowych. W ustawie o rachunkowości przewidziano uproszczone sprawozdania finansowe dla jednostek mikro, jeśli organ zarządzający podjął taką decyzję, sporządzanie uproszczonego sprawozdania finansowego nie wymaga rozbudowanej ewidencji na kontach księgowych, co stanowi duże ułatwienie dla przedsiębiorstw, ale ogranicza to wartość informacyjną sprawozdania dla osób trzecich, co może być istotne w wypadku ubiegania się o kredyt, pożyczkę lub środki europejskie (Winiarska, 2015, s. 99).

Bankowe regulacje ostrożnościowe, brak narzędzi wspomagających działalność przedsiębiorstw społecznych w zakresie zabezpieczeń i doradztwa 
finansowego, a także trudności z oszacowaniem ryzyka ich działalności to kolejne bariery w pozyskiwaniu kapitału.

Przedsiębiorstwa społeczne, które prowadzą działalność gospodarczą nie zawsze generują identyfikowalne przychody, takie jak wzrost popytu na dobra i usługi, wzrost wpływów podatkowych. Korzyści wynikające z ich działalności mogą być zidentyfikowane w dłuższym okresie, jak na przykład mniejsze wydatki na pomoc społeczną (zasiłki dla bezrobotnych, wydatki na ochronę zdrowia, wydatki na opiekę społeczną).

Przedsiębiorstwa społeczne cechuje niska stabilność przychodów, co uniemożliwia długookresowe planowanie ich działalności i obniża ich wiarygodność jako kapitałobiorców. Ograniczone możliwości dostępu przedsiębiorstw społecznych do kapitału powoduja, że skala ich działania jest mała, a nabyte kwalifikacje pracowników nie są w pełni wykorzystane, co wpływa na ograniczenie możliwości ich rozwoju w całym kraju.

Finansowanie działalności przedsiębiorstw społecznych wymaga długiego okresu zaangażowania środków, długiego okresu karencji w spłacie, względnie niskiego kosztu pozyskania i niskiego poziomu przekazanej kontroli zarządzania podmiotem (Pełka, 2012, s. 43).

\section{Główne źródła finansowania działalności podmiotów społecznych w Polsce}

Źródła finansowania podmiotów ekonomii społecznej można prezentować według różnych kryteriów. Biorąc pod uwagę pochodzenie kapitału, wyróżnia się własne i zewnętrzne źródła finansowania, natomiast ze względu na pochodzenie kapitału wyodrębnia się: środki własne z prowadzonej działalności gospodarczej i odpłatnej działalności statutowej; finansowanie bezzwrotne, czyli dotacje i granty pochodzenia rządowego, samorządowego lub z budżetu Unii Europejskiej; finansowanie zwrotne pochodzące od rynkowych instytucji finansowych, jak banki, fundusze pożyczkowe, fundusze poręczeniowe oraz środki prywatne (Waszak, 2010, s. 5).

Podstawowym źródłem finansowania przedsiębiorstwa społecznego powinna być prowadzona działalność gospodarcza związana ze sprzedażą usług i produktów. Przychód uzyskany z prowadzonej działalności jest wynikiem ekonomizacji sektora, należy jednak pamiętać, że o ile spółdzielnie (w tym socjalne) oraz spółki non-profit mogą prowadzić działalność gospodarczą bez żadnych ograniczeń, o tyle w przypadku organizacji pozarządowych działalność gospodarcza powinna być uzupełnieniem i mieć dodatkowy charakter wobec działalności statutowej. 
Oddzielnym źródłem finansowania $\mathrm{w}$ ramach działalności gospodarczej (lub statutowej odpłatnej) są zamówienia publiczne na świadczone przez podmiot usługi w oparciu o prawo zamówien publicznych, a także środki finansowe $\mathrm{z}$ dywidend, odsetek, środki $\mathrm{z}$ wynajmu lub sprzedaży majątku trwałego, środki z odpłatnej działalności statutowej (pobieranie opłat nieprzynoszących zysku, a jedynie pokrywających koszty) oraz przychody ze składek członkowskich.

Kolejnym źródłem finansowania w ramach działalności gospodarczej są dotacje na zadania publiczne realizowane w ramach działalności gospodarczej ze środków krajowych i unijnych, których cechą jest z góry określony cel, warunki wykorzystania, krótki termin finansowania, czasochłonne procedury ubiegania się o dotacje i rozliczanie ich.

W ramach działalności pożytku publicznego przedsiębiorstwa społeczne mogą realizować zadania publiczne zlecane w trybie otwartego konkursu ofert, jednak wysoki stopień sformalizowania pozyskiwania tych środków, a także możliwości podmiotów społecznych w pozyskiwaniu odbiorców usług i produktów niejednokrotnie stanowią źródło nieuczciwej konkurencji oraz konfliktów związanych z rozdziałem środków. Organizacje pozarządowe w ramach działalności pożytku publicznego mogą prowadzić działalność gospodarczą odpłatną, jednak przychody z niej mogą służyć tylko pokrywaniu kosztów związanych z tą działalnością.

Źródłem finansowania podmiotów społecznych są kredyty i pożyczki oraz poręczenia i gwarancje (instrumenty zwrotne), które w praktyce są mało dostępne dla podmiotów ekonomii społecznej, gdyż nie są one w stanie spełnić wymogów niezbędnych do uzyskania wsparcia zwrotnego na warunkach rynkowych. Instrumenty zwrotne charakteryzuje większa dowolność w dysponowaniu nimi, dłuższy okres finansowania umożliwiają realizację inwestycji, utrzymanie płynności finansowej oraz pozwalają na podejmowanie działań w dłuższym okresie.

$\mathrm{Na}$ działalność pożytku publicznego mogą być pozyskiwane środki finansowe ze źródeł prywatnych, zbiórki publiczne, darowizny i granty, środki z niepublicznych źródeł zagranicznych, odpisy $1 \%$ podatku dochodowego od osób fizycznych. Finansowanie działalności ze źródeł prywatnych daje podmiotom społecznym niezależność $\mathrm{w}$ realizacji misji i celów społecznych, a także nie występują zbiurokratyzowane formalności związane z ich pozyskaniem. Są to jednak środki trudne do pozyskania przez podmioty ekonomii społecznej (dotarcie do darczyńców, koszty reklamy itp.).

Określone prawnie formy działania przedsiębiorstw społecznych pozwalają na inne formy finansowania działalności, np.: stowarzyszenia mogą finanso- 
wać działalność ze składek członkowskich, spółki z udziałów, a spółdzielnie z udziałów i składek członkowskich. Dostępne są również dodatkowe formy wsparcia finansowego dla osób, które chcą założyć spółdzielnię socjalną lub dla osób, które chcą przystąpić do istniejącej spółdzielni socjalnej (środki z Funduszu Pracy, PEFRON).

\section{Finansowanie przedsiębiorstw społecznych}

W 2012 roku niewiele więcej niż połowa podmiotów ekonomii społecznej potwierdziła prowadzenie działalności gospodarczej (53\%). Wśród podmiotów prowadzących działalność gospodarczą $96 \%$ wykazało uzyskiwanie przychodów: do 1 tys. $-1 \%$; od 1 do 10 tys. - 4\%; od 10 do 100 tys. $24 \%$; od 100 tys. do $1 \mathrm{mln}-46 \%$; powyżej $1 \mathrm{mln}-25 \%$ organizacji (GUS, 2013, s. 67). Pomiędzy rokiem 2010 i 2012 wzrosła liczba podmiotów ekonomii społecznej prowadzących działalność gospodarczą (o 22\%), a także suma środków finansowych uzyskanych przez podmioty, co spowodowało wzrost przeciętnego poziomu ich przychodów z 1,7 do 1,9 mln zł (GUS, 2013, s. 67).

Analiza udziału poszczególnych źródeł przychodów w budżetach przedsiębiorstw społecznych prowadzących działalność gospodarczą wykazała, że największą część wszystkich uzyskanych funduszy stanowity ich przychody własne (65\% wszystkich zgromadzonych funduszy) (GUS, 2013, s. 69). Znaczącymi źródłami finansowania były też środki z dotacji subwencji publicznych (pozyskało je 47\% badanych podmiotów społecznych), które stanowiły $23 \%$ wszystkich przychodów, w tym $9 \%$ przychodów, stanowiły środki przekazane z publicznych źródeł zagranicznych.

Podmioty społeczne prowadzące działalność gospodarczą (71\%) uzyskiwały również środki przekazane przez osoby fizyczne, podmioty gospodarcze nastawione na zysk oraz inne organizacje pozarządowe. Jednakże ich wkład do sumy wszystkich zgromadzonych funduszy był niewielki (11\%). Środki pochodzące z niepublicznych źródeł zagranicznych uzyskało 5\% podmiotów, a ich udział $w$ zgromadzonych funduszach wynosił $1 \%$.

Struktura przychodów wszystkich badanych podmiotów społecznych w 2012 roku wykazała, że największa część wszystkich uzyskanych przychodów pochodziła ze źródeł o charakterze nierynkowym i uzyskało je 72\% organizacji, które wykazały posiadanie przychodów, natomiast nieco mniejsza rolę odgrywały środki pochodzące ze źródeł rynkowych, których posiadanie wykazało 38\% podmiotów (GUS, 2014, s. 119-120). 
Suma wszystkich poniesionych kosztów w 2012 roku przez organizacje prowadzące działalność gospodarczą wynosiła 6,9 mld zł, z czego $47 \%$ przeznaczono na prowadzenie działalności statutowej, $40 \%$ na prowadzenie działalności gospodarczej, a 12\% na koszty administracyjne funkcjonowania samej organizacji.

Dobra kondycja finansowa podmiotów społecznych prowadzących działalność gospodarczą wynika z faktu, że w całej analizowanej zbiorowości 54\% podmiotów uzyskało w 2012 roku dodatni wynik finansowy, w zrównoważonej sytuacji finansowej było $24 \%$ organizacji, a $22 \%$ organizacji osiągnęło deficyt budżetowy (GUS, 2013, s. 70-71).

W 2014 roku budżety ponad połowy badanych organizacji społecznych były zasilane przez krajowe środki na realizację zadán publicznych:

- ze źródeł samorządowych i administracji centralnej (60\% organizacji);

- ze składek członkowskich, dotyczy to tylko stowarzyszeń (60\% organizacji);

- z darowizn finansowych i rzeczowych od osób indywidualnych, przedsiębiorców lub instytucji (56\% organizacji);

- z przychodów z działalności gospodarczej, odpłatnej lub majątku własnego (26\% organizacji);

- z przychodów od $1 \%$ podatku dochodowego od osób fizycznych (23\% organizacji);

- z zagranicznych środków publicznych: UE, Komisja Europejska itd. (18\% organizacji);

- $\mathrm{z}$ dotacji od innych krajowych lub zagranicznych organizacji (14\% organizacji) (Adamiak, Charycka i Gumkowska, 2015, s. 15).

Roczny budżet przeciętnego podmiotu ekonomii społecznej w 2014 roku wynosił 27 tys. zł, a trzy lata wcześniej - 18 tys. zł. Przeciętna wysokość przychodów w 2014 roku była zróżnicowana w zależności od branży, a także od wieku organizacji i ich zlokalizowania w miejscowościach różniących się wielkością.

Mimo wzrostu przychodów poważnym problemem organizacji jest brak stabilności i przewidywalności finansowania. Spośród badanych organizacji tylko $56 \%$ organizacji miało zapewnione nie więcej niż połowę budżetu na 2015 rok, a $17 \%$ organizacji miało zagwarantowane $3 / 4$ budżetu. Zapewnienie stabilnego finansowania w dłuższej perspektywie na 2016 rok dla większości organizacji pozostawało poza zasięgiem (http://fakty.ngo.pl/wiadomości/1889353.html).

Struktura przychodów organizacji świadczących usługi integracji społeczno-zawodowej według źródeł była w 2016 roku zbliżona do struktury 
przychodów ogółu organizacji społecznych. Dominowały w niej przychody ze źródeł publicznych $(58,7 \%)$, w tym $27 \%$ stanowity przychody od administracji samorządowej, a tylko $1 / 3$ przychodów $(29,1 \%)$ pochodziła ze źródeł o charakterze rynkowym, z czego $13,4 \%$ były to środki z działalności gospodarczej. Relatywnie niewielką część przychodów (9\%) stanowiły przychody ze źródeł niepublicznych, a jeszcze mniejszą - ze składek członkowskich (GUS, 2018a, s. 54).

Przeprowadzona analiza źródeł finansowania podmiotów ekonomii społecznej pokazuje jedynie fragmentaryczny obraz finansowania przedsiębiorstw społecznych, gdyż nie istnieją spójne i kompleksowe dane dotyczące ich wykorzystania w praktyce. Niemniej jednak można zauważyć, że przedsiębiorczość społeczna w Polsce rozwija się dzięki wsparciu ze źródeł publicznych, głównie europejskich. W latach 2005-2008 w znacznej mierze były to środki Europejskiego Funduszu Społecznego (IW EQUAL), program Ministra Pracy i Polityki Społecznej „Wspieranie rozwoju spółdzielczości socjalnej”, Program Operacyjny Kapitał Ludzki. W nowej perspektywie finansowej na lata 2014-2020 w Krajowym Programie Rozwoju Krajowej Przedsiębiorczości Społecznej na realizację działań społecznych przewidziano 2,74 mld zł. Udział poszczególnych źródeł finansowania w ogólnej puli środków na realizację KPRES ma być następujący: 58,5\% środki z UE; 20,4\% państwowe fundusze celowe; $11,5 \%$ państwo; $7,9 \%$ samorządy terytorialne; $1,7 \%$ krajowe środki prywatne (Schimanek, 2015, s. 15).

Badania wskazują, że dość słaba kondycja finansowa podmiotów ekonomii społecznej wynika z trudności w pozyskiwaniu środków na ich działalność (Badania podmiotów..., 2015, s. 65), że większość tych przedsiębiorstw nie powstałaby bez dofinansowania ze środków europejskich, niewielki zaś procent opiera swoją działalność na przychodach z działalności gospodarczej, oczekując raczej na środki publiczne jako główne źródło finansowania.

Nieco więcej informacji można uzyskać na temat źródeł finansowania w przypadku spółdzielni socjalnych, działało ich w 2016 roku 1,4 tys. i ich liczba wzrosła o blisko $1 / 5 \mathrm{w}$ ciągu ostatnich 3 lat. Przeciętne roczne przychody spółdzielni socjalnej w 2016 roku wynosiły 308 tys. zł. Największą część spółdzielni socjalnych tworzyły jednostki osiągające roczne przychody powyżej 100 tys. zł (56\%) i grupa ta generowała największą część przychodów badanej zbiorowości (61\%). Spółdzielnie socjalne o przychodach od 10 tys. do $1 \mathrm{mln}$ zł rocznie stanowiły 35\% badanej zbiorowości, ale udział środków finansowych zgromadzonych przez te podmioty w całości osiągniętych przychodów wynosił $6 \%$. Spółdzielnie socjalne o najwyższych wpływach (powyżej $1 \mathrm{mln}$ zł) generowały zaś ponad 1/3 łącznych przycho- 
dów uzyskanych przez spółdzielnie socjalne (GUS, 2018b, s. 5). Na koniec 2016 roku zrównoważony wynik finansowy osiągnęło 4 na 10 spółdzielni socjalnych $(39 \%)$, tj. odnotowały przychody na poziomie kosztów. Podobny odsetek spółdzielni $(37 \%)$ zadeklarowało, że przychody nie pozwoliły na pokrycie kosztów działalności, a nadwyżkę przychodów nad kosztami osiągnęło 24\% spółdzielni socjalnych (GUS, 2018b, s. 5).

Spółdzielnie socjalne korzystają również ze wsparcia publicznego zarówno na etapie tworzenia spółdzielni, jak i na późniejszych etapach działalności w postaci dotacji na przystąpienie do spółdzielni socjalnej z Funduszu Pracy (FP) i PEFRON oraz ze wsparcia w początkowej fazie funkcjonowania spółdzielni - refundacji składek z FP. W 2016 roku ze środków PEFRON i FP przekazano środki w wysokości 623,6 tys. zł na rozpoczęcie działalności gospodarczej w spółdzielniach socjalnych i objęto nim 41 osób. Pomiędzy 2014 i 2016 rokiem liczba osób objętych wsparciem zmniejszyła się ponad 5-krotnie, co wskazuje na spadek zainteresowania tą formą aktywizacji (GUS, 2018b, s. 6).

Ważnym instrumentem wsparcia finansowego spółdzielni socjalnych są środki z EFS w ramach projektów dotyczących ekonomii społecznej realizowanych przez Ośrodki Wsparcia Ekonomii Społecznej (OWES) oraz Regionalne Ośrodki Polityki Społecznej (ROPS). W 2016 roku w ramach regionalnych programów operacyjnych wsparciem finansowym i pozafinansowym objęto 341 spółdzielni socjalnych (38\% aktywnych podmiotów) (GUS, 2018b, s. 7).

Wśród instrumentów wsparcia współfinansowanych ze środków europejskich są również preferencyjne pożyczki oferowane przez Bank Gospodarstwa Krajowego (BGK) na rozwój działalności i tworzenie nowych miejsc pracy. W 2016 roku udzielono spółdzielniom socjalnym 55 pożyczek na kwotę 3,7 mln zł. Natomiast w latach 2013-2016 udzielono łącznie ponad 500 pożyczek dla 401 przedsiębiorstw społecznych (w tym 256 spółdzielniom socjalnym) na kwotę 39 mln zł (GUS, 2018b, s. 8; http://esfundusz.pl/?p=2319).

$\mathrm{Z}$ analizy danych dotyczących możliwych źródeł finansowania i kondycji finansowej przedsiębiorstw ekonomii społecznej wynika, że znaczący jest udział środków publicznych w finansowaniu ich działalności, a szczególnie dotyczy to spółdzielni socjalnych. Natomiast w niewielkim zakresie przedsiębiorstwa społeczne korzystają z instrumentów zwrotnych: kredytów na finansowanie inwestycji, kredytów obrotowych na finansowanie bieżących potrzeb związanych z prowadzoną działalnością oraz kredytów pomostowych na przedsięwzięcia refinansowane ze środków UE, mikropożyczek i poręczeń. 
Przyjęty w sierpniu 2014 roku Krajowy Program Rozwoju Ekonomii Społecznej wskazuje na potrzebę wsparcia ekonomii społecznej w dostępie do zewnętrznych źródeł finansowania i wdrożenia programu finansowania podmiotów społecznych opartego na zwrotnych instrumentach finansowych.

Towarzystwo Inwestycji Społeczno-Ekonomicznych SA, w ramach podpisanej z BGK S.A. umowy, udzielało preferencyjnych pożyczek dla przedsiębiorstw społecznych ze środków PO KL 2007-2013 i były one udzielane do końca 2015 roku - wartość udzielonych pożyczek 30,2 mln zł, udzielono 382 pożyczki i wsparto 311 podmiotów PES. Po tym czasie planowane jest rozszerzenie oferty wsparcia PES $w$ ramach perspektywy finansowej 2014-2020 ze środków Programu Operacyjnego Wiedza, Edukacja Rozwój, poza preferencyjnymi pożyczkami od 2017 roku oferta zostanie rozszerzona o gwarancje i reporęczenia. Pożyczki mają być przeznaczane na rozszerzenie prowadzonej działalności, wzmocnienie podstawowej działalności PES lub realizację nowych przedsięwzięć. PES w ramach przedsięwzięcia objętego dofinansowaniem powinien generować korzyści społeczne. Dla PES, które nie działają dłużej niż 12 miesięcy przewidziane są pożyczki na start w wysokości do 100 tys. zł, na następujących warunkach: maksymalny okres spłaty 5 lat, karencja w spłacie do 6 miesięcy, brak prowizji i opłat, oprocentowanie na poziomie spłaty redyskonta weksli NBP (obniżenie do $1 / 2$ redyskonta weksli NBP, gdy celem przedsięwzięcia jest m.in. utworzenie nowego miejsca pracy w ramach pożyczki). Dla PES, które działają powyżej 12 miesięcy dedykowana jest pożyczka na rozwój do 500 tys. zł, na warunkach: okres spłaty 7 lat, karencja w spłacie do 6 miesięcy, brak prowizji i opłat, oprocentowanie uzależnione od kwoty pożyczki (do 100 tys. zł na poziomie stopy redyskonta weksli NBP, z możliwością obniżenia do $1 / 2$ stopy redyskonta weksli (nowe miejsce pracy), powyżej 100 tys. zł na poziomie rynkowym, możliwość obniżenia do wysokości stopy redyskonta weksli, gdy w ramach przedsięwzięcia utworzona zostanie liczba miejsc pracy odpowiadająca kwocie zaciągniętej pożyczki w proporcjach, zgodnie z którymi 100 tys. zł pożyczki przekłada się na 1 miejsce pracy).

4 kwietnia 2017 roku odbyła się konferencja otwierająca program realizowany przez BGK S.A. na zlecenie Ministra Rodziny i Polityki Społecznej, oferujący kompleksowe wsparcie dla podmiotów ekonomii społecznej $\mathrm{z}$ wykorzystaniem instrumentów finansowych. W projekcie przewidziano ponad $135 \mathrm{mln}$ zł na preferencyjne pożyczki oraz ponad $4 \mathrm{mln}$ zł na reporęczenia. Fundusze pochodzą z Programu Wiedza Edukacja Rozwój. Dzięki tym środkom wsparcie otrzyma minimum 2030 PES i powstanie 1250 miejsc pracy w obszarze ekonomii społecznej. 
W 2017 roku Ministerstwo Rodziny, Pracy i Polityki Społecznej podpisało z BGK S.A. umowę, która powołała Fundusz Gwarancyjny Krajowego Funduszu Przedsiębiorczości Społecznej. W ramach funduszu, podmiotom ekonomii społecznej zostaną udostępnione gwarancje, które pozwolą zwiększyć dostępność rynkowych źródeł finansowania, dzięki istotnemu zmniejszeniu ryzyka zobowiązań zaciąganych przez te podmioty $w$ instytucjach finansowych działających na warunkach komercyjnych. Uzyskane od instytucji finansowych środki istotnie wpłyną na funkcjonowanie PES i umożliwią im finansowanie celów statutowych, a także dokonanie inwestycji na rozwój infrastruktury oraz budowę jej zaplecza finansowego. Lepsza kondycja finansowa PES pozwoli im lepiej konkurować na rynku z innymi usługodawcami, a prowadzenie dokładniejszej księgowości będzie wywierało korzystny wpływ na efektywność zarządzania organizacją.

Zaproponowane w KPRES rozwiązania zwrotnego finansowania podmiotów ekonomii społecznej będą zapewne impulsem do rozwinięcia działalności gospodarczej, w szczególności poczynienia niezbędnych w tym celu inwestycji. Na wyniki podjętych działań trzeba będzie jednak poczekać.

\section{Podsumowanie}

Z przeprowadzonej analizy wynika, że przedsiębiorstwa społeczne znajdują się w nie najlepszej sytuacji finansowej, która pozwala im jedynie utrzymywać działalność na minimalnym poziomie. Ich niewielkie przychody oraz mały udział w działalności gospodarczej powodują, że nie są w stanie samodzielnie zadbać o podstawy bytu i w większości przypadków funkcjonują jako beneficjanci pomocy społecznej w postaci dotacji.

Rosnący udział środków publicznych w finansowaniu działalności PES wywołuje ich mniejsze zainteresowanie rozwijaniem działalności gospodarczej, a wybór przedmiotu ich działalności dokonywany jest nie na podstawie analizy rynku, a realizacji z góry wyznaczonego celu społecznego dopasowanego do możliwości pracowników przedsiębiorstwa.

Działalność przedsiębiorstw społecznych może być finansowana z różnych źródeł: środków własnych wypracowanych w ramach prowadzonej działalności gospodarczej; finansowania bezzwrotnego (dotacje i granty rządowe i samorządowe lub z budżetu UE); finansowania zwrotnego (kredyty, mikropożyczki, poręczenia i gwarancje), a także ze środków prywatnych (udziały, darowizny). Przedsiębiorstwa społeczne w niewielkim zakresie korzystają z instrumentów zwrotnych, których oferta była dotychczas dla przedsię- 
biorstw społecznych niewielka, a podmioty ekonomii społecznej nie miały doświadczenia $\mathrm{w}$ korzystaniu $\mathrm{z}$ niej.

Obecnie wykorzystanie finansowania zwrotnego jako narzędzia zabezpieczenia płynności i źródła finansowania rozwoju przedsiębiorczości społecznej zostały zawarte w KPRES, a przełożenie zawartych w nim ogólnych zapisów na działania operacyjne i ich konsekwentna realizacja spowoduje, że przedsiębiorstwa społeczne w mniejszym stopniu będą uzależnione od środków publicznych, w większym zaś będą mogły budować swoją samodzielność finansową.

Przedsiębiorstwa społeczne mają szansę dzięki wykorzystaniu instrumentów zwrotnych na finansowanie działalności, stworzyć trwałe podstawy swojego funkcjonowania poprzez równoważenie celów społecznych i ekonomicznych.

\section{Literatura}

Adamiak, P., Charycka, B. i Gumkowska M. (2015). Polskie Organizacje Pozarzadowe 2015. Warszawa: Stowarzyszenie Klon/Jawor. Pozyskano z: http://fakty.ngo.pl/files/fakty.ngo.pl/ public/kondycja_2015/KondycjaNGO2015.pdf.

Badania podmiotów ekonomii społecznej w subregionie południowym województwa śląskiego. (2015). Bielsko-Biała: Stowarzyszenie Bielskie Centrum Przedsiębiorczości.

GUS. (2013). Raport końcowy pomiaru wptywu EFS na poziom zatrudnienia i ekonomizacje podmiotów ekonomii spotecznej w ramach badania SOF-1 za rok 2012. Warszawa: GUS.

GUS. (2014). Trzeci sektor w Polsce. Stowarzyszenia, fundacje, spoteczne podmioty wyznaniowe, organizacje samorzadu zawodowego, gospodarczego i pracodawców w 2012 roku. Warszawa: GUS.

GUS. (2018a). Rola sektora non-profit w dostarczaniu ustug spotecznych w latach 2014-2016. Kraków: GUS.

GUS. (2018b). Spótdzielnie socjalne w 2016 roku. Informacja sygnalna. Warszawa: GUS.

Herbst, I. (2008). Analiza możliwości finansowania podmiotów ekonomii spotecznej. Warszawa: Bank DnBNORD.

http://esfundusz.pl/?p=2319 (25.06.2018).

http://fakty.ngo.pl/wiadomości/1889353.html (29.06.2018).

Pełka, W. (2012). Rynkowe instrumenty finansowania działalności przedsiębiorstw społecznych w Polsce. Ekonomia Spoteczna, 2.

Schimanek, T. (2015). Finansowanie przedsiębiorstw społecznych w Polsce. Ekonomia Społeczna, 2.

Waszak, Ł. (2010). Finansowanie ekonomii spotecznej w Polsce. Wyzwania na przysztość. Warszawa: Ogólnopolska Federacja Organizacji Pozarządowych.

Winiarska, K. (2015). Jednostki mikro według ustawy o rachunkowości. W: M. Postuła, J. Turyna (red.), Finansowe uwarunkowania rozwoju organizacji gospodarczych. Zarzadzanie finansami a efektywność. Warszawa: Wydawnictwo Naukowe Wydziału Zarządzania UW. 



\section{RENATA KARKOWSKA*, ANDRZEJ SOPOĆKO**}

\section{Zjawisko zmienności $i$ wspótzależności indeksów na rynku kapitatowym}

Krajobraz rynku kapitatowego po globalnym kryzysie finansowym 2008-2009 cechuje względnie niskie ryzyko zmian cen aktywów finansowych, ale zjawisko pogtębiającej się integracji rynków sprzyja procesom zarażania zmiennościa rynkowa. Proces ten stawia pod znakiem zapytania możliwości dywersyfikacji ryzyka. Rozdziat prezentuje wyniki analizy zmienności $i$ wspótzależności pomiędzy gietdami finansowymi. Badanie zostato wykonane na podstawie reskaźników zmienności $i$ korelacji cen pomiędzy indeksami gietdowymi: SEP500, Dow Jones, FTSE100, DAX, NIKKEI225, Hang Seng, WIG, BUX w latach 2005-2015. Wyniki dowiodty, że ryzyko systematyczne na rynku kapitatowym ma charakter stabilny w okresie po globalnym kryzysie finansowym 2008-2009, natomiast zmienia się w czasie $i$ jest coraz silniejsza wspótzależność pomiędzy badanymi rynkami.

Słowa kluczowe: rynek kapitałowy, zmienność cen aktywów, efekt zarażania, korelacja cen.

\section{VOLATILITY AND INTERDEPENDENCE OF INDICES ON THE CAPITAL MARKET}

After the global financial crisis of 2008-2009, the capital market is characterized by a relatively low risk of price volatility of financial assets, but the deepening integration of markets favors the effect of contagion. This process makes it difficult to diversify risk. The article presents the results of an analysis of volatility and interdependencies between stock exchanges. The study was based on volatility indices and price correlation ratios between stock exchange indices: SEP500, Dow Jones, FTSE100, DAX, NIKKEI225, Hang Seng, WIG, BUX in the 2005-2015 period. The results proved that the systemic risk on the capital market was stable in the period after the global financial crisis

\footnotetext{
" Dr hab. Renata Karkowska - Wydział Zarządzania Uniwersytetu Warszawskiego.

* Prof. dr hab. Andrzej Sopoćko - Wydział Zarządzania Uniwersytetu Warszawskiego.
} 
of 2008-2009. However, it is changing over time and the correlation between capital markets is growing..

Keywords: capital market, volatility of asset prices, contagion effect, price correlation.

JEL: G1, G11, G10, M21

\section{Wprowadzenie}

Zjawisko współzależności zmian cen aktywów finansowych nie jest nowe, nabrało ono jednak zasadniczego znaczenia $\mathrm{w}$ dobie szybkiego transferu informacji. W literaturze przedmiotu często jest ono określane pojęciami zapożyczonymi z medycyny jako "efekt zarażenia” (contagion effect) czy przyrody jako „efekt monsunowy” (Budnikowski, 2006). Określenie to znajduje również swoje zastosowanie na rynku finansowym. Efekt zarażania na rynkach kapitałowych jest definiowany głównie jako korelacja między cenami aktywów giełdowych. Definicja zarażania została rozwinięta w literaturze teoretycznej, przy minimalnym udziale literatury empirycznej. Dlatego zaproponowane badanie ma na celu weryfikację ryzyka zmienności cen aktywów na rynku kapitałowym oraz analizę współzależności cen. Autorzy zakładaja, że spadek zmienności indeksów giełdowych, jaki ma miejsce po globalnym kryzysie finansowym 2008-2009, nie oznacza bezpieczniejszej sytuacji dla inwestorów finansowych. Przyczyna leży w rosnącym zjawisku współzależności cen aktywów, co ogranicza możliwości skutecznej dywersyfikacji portfela inwestycyjnego. Celem Autorów było spojrzenie na zjawisko z perspektywy globalnej oraz w czasie obejmującym okres przed i po kryzysie finansowym 2008-2009. Badanie zostało poprzedzone studiami literaturowymi (teoretycznymi i empirycznymi).

Analiza ma charakter teoretyczno-empiryczny i składa się z czterech części: przeglądu literatury przedmiotu, opisu metody badawczej, prezentacji wyników dokonanych analiz oraz wniosków końcowych.

\section{Przegląd literatury}

Pierwsze badania na temat zmienności rynków finansowych koncentrowały się na makroekonomicznych determinantach niestabilności rynku finansowego (Schwert, 1989). W kolejnych krokach zostały wykorzystane do opracowania udoskonalonych modeli prognozowania zmienności, szcze- 
gólnie w długich okresach (Engle i Rangel, 2008; Engle i in., 2013). Paye (2012) i Christiansen i in. (2012) analizują związek między niestabilnością finansową a warunkami makroekonomicznymi. W warunkach globalizacji rynków finansowych zmienność przepływów kapitałowych staje się przyczyną niestabilności i narastania ryzyka zmian cen aktywów. Strumienie kapitału inwestycyjnego i krótkoterminowego spekulacyjnego powodują większą zmienność cen na rynku, co prowadzi do zwiększonej niepewności i ryzyka rynkowego. Według teorii portfelowej procesem służącym zabezpieczeniu ryzyka rynkowego służy dywersyfikacja. Dywersyfikacja ryzyka sprowadza się do alokowania aktywów pomiędzy różne podmioty, branże, gałęzie i struktury gospodarki. Zasadą jest, że inwestowanie w wiele projektów jest mniej ryzykowne niż inwestycje w jeden obciążony ryzykiem. Zaletą tego jest niewątpliwie fakt, że finansowaniu podlegają również przedsięwzięcia obarczone większą niepewnością. Jednak procesy integracji gospodarek krajów powoduje, że zmiany stóp procentowych i kursów walutowych oraz płynność rynków finansowych nie są już wynikiem działania polityki makroekonomicznej danego kraju. I to nie one stanowią w głównej mierze o ryzyku rynkowym inwestycji, ale poziom współzależności pomiędzy podmiotami i rynkami. Ostatni kryzys finansowy był tego dobrym przykładem, jak ważne jest, aby spojrzeć na powiązania pomiędzy instytucjami finansowymi. Doświadczenia pokazały, że większe zakłócenia, takie jak upadłość czy problemy rozliczeniowe niektórych instytucji szybko rozprzestrzeniły się na cały system finansowy. Elsinger, Lehar i Summer (2004; 2006) dowiedli, że korelacja między papierami na rynku powoduje mniejsze korzyści z dywersyfikacji oraz większe ryzyko związane ze stosowaniem dźwigni finansowej. Badanie zostało oparte na powiązaniach systemowych na rynku międzybankowym oraz wpływie ryzyka kredytowego i rynkowego na wartość banku w Austrii. Jako wartość banku przyjęli kapitały własne skorygowane o lokaty i kredyty w innych bankach oraz o oszacowany wynik z portfela kredytowego i z tytułu obrotu papierami wartościowymi dla sektora pozabankowego.

$\mathrm{Z}$ punktu widzenia niniejszego opracowania niezwykle przydatną okazała się klasyfikacja metod pomiaru integracji rynków finansowych, zestawiona przez U. Mrzygłód (2011) (zob. tab. 1).

Niestety integracja rynków finansowych ma również swoje wady. Szczególnie istotnym minusem jest efekt zarażania. Zjawisko to można rozpatrywać w kontekście: 1) wymiany transgranicznej (narastania powiązań między krajami); 2) asymetrii faz cyklu koniunkturalnego kraju, regionu czy świata; 3) psychologicznego efektu zachowania inwestorów. Schuler (2002) wskazuje na szok: międzysektorowy (przenoszenie niestabilności z podmiotu 
działającego w danej grupie kapitałowej na inny podmiot będący w tej samej grupie), mikroekonomiczny (przenoszący się poprzez informację lub zaangażowanie kapitałowe instytucji na rynku międzybankowym bądź w systemie płatniczym) i makroekonomiczny (pogorszenie koniunktury gospodarczej, wzrost zmienności na rynkach finansowych).

Tabela 1. Główne miary integracji rynków finansowych

\begin{tabular}{|c|c|c|}
\hline $\begin{array}{c}\text { Podstawa } \\
\text { budowy } \\
\text { wskaźników }\end{array}$ & Rynek akcji & Rynek obligacji \\
\hline Cena & $\begin{array}{l}\text { - korelacja stóp zwrotu z aktywów } \\
\text { - korelacja indeksów giełdowych } \\
\text { - kointegracja indeksów giełdowych } \\
\text { - wielkość zróżnicowania stóp zwro- } \\
\text { tu z aktywów pomiędzy krajami }\end{array}$ & $\begin{array}{l}\text { - zróżnicowanie stóp dochodowości (ana- } \\
\text { liza spreadów) } \\
\text { - konwergencja stóp dochodowości } \\
\text { - korelacje stóp dochodowości } \\
\text { - stopień determinacji stóp dochodowości } \\
\text { - przez czynniki lokalne kraju } \\
\text { - porównanie oceny kredytowej (rating) } \\
\text { testy parytetu stóp procentowych }\end{array}$ \\
\hline \multirow[t]{2}{*}{$\begin{array}{l}\text { Wielkość } \\
\text { rynku }\end{array}$} & $\begin{array}{l}\text { - udział podmiotów zagranicznych } \\
\text { na krajowym rynku papierów } \\
\text { udziałowych } \\
\text { - udział zagranicznych akcji w port- } \\
\text { felu krajowych inwestorów indywi- } \\
\text { dualnych oraz instytucjonalnych } \\
\text { - wielkość emisji zagranicznych akcji }\end{array}$ & $\begin{array}{l}\text { - udział podmiotów zagranicznych na kra- } \\
\text { jowym rynku obligacji } \\
\text { - udział zagranicznych obligacji w portfelu } \\
\text { krajowych inwestorów instytucjonalnych } \\
\text { i indywidualnych } \\
\text { - wielkość emisji zagranicznych obligacji } \\
\text { oraz dostęp krajowych spółek do zagra- } \\
\text { nicznych rynków obligacji }\end{array}$ \\
\hline & \multicolumn{2}{|c|}{$\begin{array}{l}\text { - międzynarodowe przepływy kapitału w oparciu o bilans płatniczy } \\
\text { - fuzje i przejęcia międzynarodowe } \\
\text { - stopień rozłożenia ryzyka } \\
\text { - międzynarodowa pozycja inwestycyjna (otwartość gospodarki na inwestorów) }\end{array}$} \\
\hline Informacje & \multicolumn{2}{|c|}{$\begin{array}{l}\text { - analiza wariancji stóp zwrotu z indeksów giełdowych (wpływ czynników świa- } \\
\text { towej i lokalnej na stopy zwrotu i zmiany cen aktywów) }\end{array}$} \\
\hline
\end{tabular}

Źródło: Karkowska, 2015; za: Adam et al., 2002; Baele et al., 2004; Buch, 2004, s. 15-38; Baltzer et al., 2008; Mrzygłód, 2011, s. 16-18.

Interesujące wnioski na temat efektu współzależności na rynkach finansowych wnosi do literatury światowej Sell (2001), który wskazuje na kanały jej rozprzestrzeniania:

- zachowania stadne inwestorów instytucjonalnych w warunkach niepelnej informacji, powodujące efekt domina;

- centralne procedury instytucji finansowych w zakresie zarządzania ryzykiem, generujące ryzyko systemowe w rejonach odległych geograficznie od źródła niestabilności; 
- spekulacje wykorzystujące arbitraż stóp procentowych i prawny między lokalnymi rynkami finansowymi;

- instrumenty pochodne wykorzystujące nadmiernie dźwignię finansową, łączące rynki finansowe w skali globalnej;

- kryzys zaufania na rynkach finansowych wywołany nieodpowiedzialnością działań polityków;

- znaczny deficyt bilansu płatniczego, powodujący zaburzenia równowagi makroekonomicznej;

- powiązania handlowe, gdzie kryzys w jednym kraju prowadzi do zastojów gospodarczych w krajach, dla których jest on rynkiem zbytu; dzieje się tak bez względu na początkową stabilność makroekonomiczną (Solarz, 2008).

Efekt zarażania podczas kryzysów walutowych w krajach azjatyckich i latynoamerykańskich w postaci: powiązań handlowych, niespójności polityki monetarnej, cyklu koniunkturalnego oraz zachowań inwestorów zauważyli Eichengreen i in. (1995; 1996; 1998) oraz Lowell i in. (1998). Częstym źródłem przenoszenia niestabilności jest bieżąca ocena inwestorów, którzy łączą problemy kraju inwestycji z bieżącymi problemami krajów o podobnym ryzyku makroekonomicznym (Chang i Majnoni, 2000). Równie popularną formą przenoszenia zaburzeń jest mechanizm współzależności między centrum a strefami pobocznymi niestabilności. Efekt przenoszenia niestabilności cen aktywów przybiera najczęściej następujące formy: gospodarczy, psychologiczny oraz zarażania pomiędzy spółkami matką i córką (por. tab. 2).

Tabela 2. Formy przenoszenia zmian cen aktywów

\begin{tabular}{|l|l|}
\hline \multicolumn{1}{|c|}{ Forma } & \multicolumn{1}{c|}{ Opis } \\
\hline $\begin{array}{l}\text { Gospodarczy efekt zara- } \\
\text { żania }\end{array}$ & $\begin{array}{l}\text { sytuacja gospodarcza danego kraju jest bliska sytuacji kraju dotknię- } \\
\text { tego kryzysem }\end{array}$ \\
\hline Efekt psychologiczny & $\begin{array}{l}\text { inwestorzy traca zaufanie do wszystkich krajów danego regionu, } \\
\text { gdy wybucha kryzys tylko w jednym kraju, należy zaznaczyć, ze } \\
\text { parametry ekonomiczne tych krajów nie wskazują na złą sytuację } \\
\text { gospodarczą. Ten mechanizm zarażenia się jest bliski krajom rynków } \\
\text { wschodzących }\end{array}$ \\
\hline $\begin{array}{l}\text { Zarażenie spółki córki } \\
\text { przez spółkę matkę }\end{array}$ & $\begin{array}{l}\text { sytuacja szczególnie istotna w krajach wschodzących, ze względu na } \\
\text { strukturę własności instytucji finansowych, gdzie przeważa kapitał } \\
\text { zagraniczny. Spółka matka, która przeżywa problemy finansowe, } \\
\text { transferuje straty do córki, co może w efekcie prowadzić do ban- } \\
\text { kructwa tej drugiej }\end{array}$ \\
\hline
\end{tabular}


W kontekście rozważań nad efektami zarażania należy zwrócić uwagę na zjawisko pogłębiającej się integracji rynków finansowych. Przez integrację rynków finansowych rozumiane jest zjawisko, którego podłożem są procesy zachodzące $\mathrm{w}$ gospodarce światowej, generujące możliwość wolnego przepływu usług i kapitału finansowego. W polskiej literaturze obszernie na temat integracji rynków pisze Iwanicz-Drozdowska (2007). Procesy integracji rynków finansowych zbiegły się ze światową tendencją do globalizacji. Jako zaletę integracji rynków finansowych wymienia się:

- obniżenie kosztów transakcyjnych dla instrumentów finansowych,

- redukcję kosztów transakcyjnych związanych z przeprowadzaniem rozliczeń i płatności,

- bogatszy dostęp do finansowania, co powinno przyczynić się do pobudzenia inwestycji,

- poprawę oceny ryzyka kredytowego, a tym samym - docelowo - do obniżenia ceny kredytu,

- możliwość swobodnego wejścia instytucji finansowych na rynki lokalne przyczynia się do wzrostu konkurencji, a tym samym powinny mieć pozytywny wpływ zarówno na jakość świadczonych usług, jak i ich ceny (Karkowska, 2015).

Przegląd literatury dotyczącej efektów zarażania kryzysem wskazuje na bogate treści teoretyczne, ale i braki w badaniach empirycznych nad znalezieniem wspólnych czynników wywołujących mechanizm zaburzeń. Nie jest to zapewne sprawa prosta, ze względu na nakładanie się kryzysów politycznych na efekt zarażania ryzykiem systemowym. Niektórzy badacze podkreślają, że panaceum na efekt zarażania jest powolne tempo rozprzestrzeniania się kryzysu, co pozwala przewidzieć ich reakcję i przygotować mechanizmy obronne (Kim, 2004).

\section{Opis metody badawczej}

Studia literaturowe skłoniły autorów do pogłębienia wcześniejszego wnioskowania o podatności danego rynku kapitałowego na szoki płynące z zewnątrz i na tzw. efekt zarażania. Zgodnie ze współczesnymi standardami metodycznymi, obiektem analizy były współczynniki zmienności. Podczas badania związków między wskaźnikami zmienności różnych giełd pojawia się problem: którą zmienną wziąć: historyczną czy implikowana. Jak się wyda- 
je, w tym przypadku argumenty przemawiają jednoznaczne za historyczną. Trzeba jednak $\mathrm{w}$ tej sytuacji odpowiedzieć na pytanie, dlaczego tak, jeśli w praktyce stosuje się zmienność implikowaną. Otóż dla celów utylitarnych parametr zmienność stosuje się przede wszystkim do wyceny instrumentów pochodnych. Chodzi o podanie takiej ceny, która daje jednakowe korzyści dla długiej i krótkiej pozycji. Oznacza to, że przy danej cenie wartości korzyści i strat dla każdej ze stron są takie same. Problemu by nie było, gdyby na rynku bazowym występowałyby stacjonarne procesy stochastyczne, odpowiadające np. ruchom Browna. Tak jednak nie jest. Na rynku pojawiają się bowiem dłuższe i krótsze fale czy załamania trendów. Przeoczenie nadejścia dłuższej fali jest jak stawianie żagli w wariancie lekkiego wietrzyku, kiedy nadchodzi burza. Podobnie na rynku finansowym. Te same instrumenty będą miały różne parametry zachowań, w zależności od jego stanu.

Przyjmuje się na ogół istnienie dwu aksjomatów. Pierwszy: rynek najlepiej wyczuwa sytuację, która ma nastąpić. Drugi - i tak często się myli. Jest więc najlepszym źródłem wiedzy o przyszłości, ale nie można na nim do końca polegać. Dobrym obrazem niedoskonałości rynku jest kształtowanie implikowanego współczynnika zmienności w okresie stosunkowo dużych niepokojów rynkowych. Otóż prawidłowym obrazem byłby tzw. uśmiech krzywej zmienności. Parametr zmienności implikowanej nie jest bowiem stały. Zmienia się wraz z odległością ceny bazowej od ceny wykonania. Najniższy jest dla strike price równej cenie bazowej. Dla obu opcji: call i put, najwyższy w sytuacji wysoko in the money (rys. 1 linia przerywana).

Rzeczywistą i teoretyczną zmienność wskaźnika zmienności można przedstawić w decylach odległości od punktu ATM, gdzie strike price równa cenie bazowej. Jeśli cały obszar zmienności ceny bazowej określimy w decylach i weźmiemy dla opcji put decyle w lewo od ATM, a dla opcji call - na prawo, to powinniśmy otrzymać wspomniany wyżej uśmiech. Okazuje się jednak, że w rzeczywistości rzadko tak jest. $\mathrm{Na}$ rysunku 1 przedstawiono zmienność parametru volatility $\mathrm{w}$ Polsce, w okresie, gdy gospodarka w kraju i na świecie znajdowała się w fazie wychodzenia z kryzysu. Okazuje się, że tylko dla pochodnych wystawionych 21 listopada 2008 r. kształt krzywej rzeczywistej był, w pewnym stopniu, zbliżony do postaci teoretycznej. Taki stan rzeczy tłumaczy się na ogół niską płynności pochodnych o strike price istotnie odbiegających od ceny bazowej i sentymentu rynku. Przy oczekiwaniu utrzymywania się trendu zwyżkowego cen, opcje put były wysoce niedowartościowane i przy rzadkich transakcjach, ceny powielały wysokość z poprzednich sesji. 
Rysunek 1. Zmienność teoretyczna i rzeczywista wskaźnika implied volativity na rynku FX w Polsce dla opcji wystawianych w kolejnych miesiącach

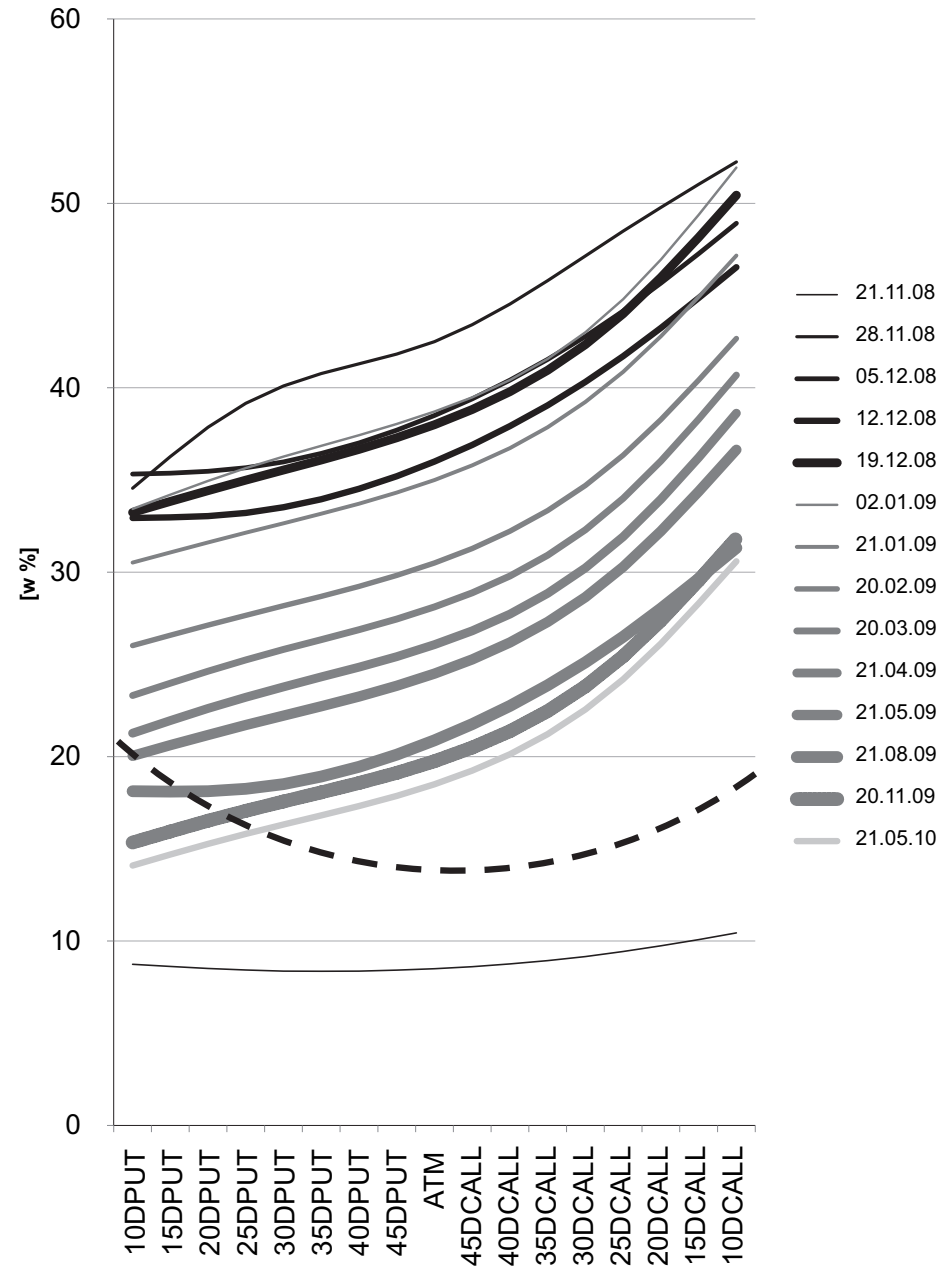

Źródło: Bloomberg. Zmienność teoretyczna (linia przerywana), zmienność rzeczywista (linie ciągłe).

Z rysunku 1 wynika, że w licznych sytuacjach wartości zmiennej implikowanej ulegają silnym emocjom uczestników rynku i wcale nie są dobrym odwzorowaniem zmienności rzeczywistej. Jako obszar oceny związków między poszczególnymi rynkami mają wartość wątpliwą. Co prawda, do prognozowania przyszłych stanów rynku i tak są najlepsze, ale branie ich do analizy zależności z przeszłości mija się z celem. Chodzi tu przecież nie o to, by dobrze typować przyszłe parametry, ale określić ich cechę, jaka 
w przeszłości wydawała się występować. Do diagnozowania mechanizmów ekonomicznych nie stosujemy przecież związków między prognozami, ale między ich stanami a właściwościami parametrów. Stąd sięgnięcie po zmienne historyczne wydało się jedynym racjonalnym rozwiązaniem.

W dalszej analizie wykorzystano najbardziej popularne w skali globalnej indeksy giełdowe: amerykańskie: S\&P500 i Dow Jones, europejskie: FTSE oraz indeks DAX, azjatyckie: indeks Nikkei 225 oraz indeks Hang Seng oraz lokalne indeksy krajów mniej rozwiniętych: warszawski WIG i węgierski BUX. W tabeli 3 przedstawiono statystykę opisową dla stóp zwrotu $\mathrm{z}$ analizowanych indeksów giełdowych, obejmujących 3130 sesji, odbytych w ciągu 10 lat (2005-2015). Prezentowane wartości statystyk opisowych indeksów zostały obliczone na podstawie kursów na zamknięcie sesji. Analiza wykazała, że największą zmiennością charakteryzowały się indeksy azjatyckie - NIKKEI (1,51), HANG SENG $(1,50)$, oraz warszawski WIG $(1,22)$ i węgierski BUX $(1,57)$.

Tabela 3. Statystyka opisowa

\begin{tabular}{|l|c|c|c|c|c|}
\hline \multicolumn{1}{|c|}{ Zmienna } & Obs & Średnia & Odch. stand. & Min & Max \\
\hline SPX & 3130 & 0,0269334 & 1,209482 & $-9,034980$ & 11,580040 \\
\hline DJI & 3130 & 0,0257163 & 1,116665 & $-7,873277$ & 11,080330 \\
\hline FTSE & 3130 & 0,0191685 & 1,173742 & $-8,849275$ & 9,838771 \\
\hline GDAXI & 3130 & 0,0411434 & 1,374355 & $-7,163902$ & 11,401950 \\
\hline N225 & 3130 & 0,0278311 & 1,518207 & $-11,406370$ & 14,150300 \\
\hline HSI & 3130 & 0,0252258 & 1,505191 & $-12,700050$ & 14,347070 \\
\hline WIG & 3130 & 0,0292322 & 1,228442 & $-7,954595$ & 6,272617 \\
\hline BUX & 3130 & 0,0371002 & 1,571063 & $-11,88166$ & 14,085440 \\
\hline
\end{tabular}

Źródło: opracowanie własne na podstawie danych Thomson Reuters Eikon.

$\mathrm{Na}$ podstawie zmian dziennych wartości indeksów giełdowych zostały oszacowane wskaźniki zmienności. W tym celu w badaniu posłużono się miarą odchylenia standardowego dziennych stóp zwrotu indeksu skorygowaną liczbą dni w roku. W drugim kroku badania oszacowane zostało zjawisko współzależności pomiędzy wskazanymi giełdami. W tym celu wykorzystano wskaźniki korelacji pomiędzy dziennymi wartościami indeksów giełdowych w poszczególnych latach. Badanie obejmowało okres przed i po kryzysie finansowym 2005-2015. Celem badania jest wskazanie, w jakim stopniu zmiany cen aktywów są podyktowane zmianami płynącymi z zewnątrz czy zmien- 
ność jednego indeksu wpływa na zmienność innych, czy zjawiska nasilające trend na jednym rynku wpływają na pozostałe i w jakim stopniu?

\section{Wyniki}

W tabeli 4 zostały zaprezentowane wskaźniki zmienności historycznej analizowanych indeksów giełdowych w kolejności narastającej w latach 2005-2015.

Tabela 4. Wskaźniki zmienności historycznej indeksów giełdowych w latach 2005-2015

\begin{tabular}{|c|c|c|c|c|c|c|c|c|}
\hline ROK & SPX & \multicolumn{1}{|c|}{ DJI } & FTSE & GDAXI & N225 & HSI & WIG & BUX \\
\hline 2005 & 9,97 & 9,93 & 8,44 & 11,88 & 13,96 & 11,38 & 13,12 & 22,42 \\
\hline 2006 & 9,73 & 9,50 & 11,85 & 14,64 & 17,60 & 16,30 & 19,92 & 22,83 \\
\hline 2007 & 14,90 & 13,52 & 17,58 & 15,88 & 20,65 & 31,40 & 19,87 & 19,28 \\
\hline 2008 & 34,75 & 32,45 & 32,78 & 33,00 & 38,83 & 47,03 & 28,23 & 36,55 \\
\hline 2009 & 25,06 & 22,10 & 20,64 & 25,85 & 23,53 & 22,06 & 27,11 & 34,00 \\
\hline 2010 & 16,53 & 14,79 & 15,98 & 16,71 & 21,66 & 18,07 & 15,14 & 23,82 \\
\hline 2011 & 20,42 & 18,40 & 19,54 & 26,72 & 17,74 & 22,85 & 19,21 & 25,65 \\
\hline 2012 & 12,30 & 11,37 & 13,24 & 17,62 & 18,56 & 14,82 & 13,60 & 16,95 \\
\hline 2013 & 10,64 & 9,58 & 11,11 & 13,61 & 25,32 & 13,73 & 14,26 & 16,80 \\
\hline 2014 & 10,33 & 9,88 & 10,94 & 16,50 & 15,99 & 19,81 & 12,65 & 17,15 \\
\hline 2015 & 14,34 & 14,43 & 18,23 & 24,63 & 24,69 & 18,29 & 13,70 & 16,53 \\
\hline Średnia & $\mathbf{1 6 , 2 7}$ & $\mathbf{1 5 , 0 9}$ & $\mathbf{1 6 , 3 9}$ & $\mathbf{1 9 , 7 3}$ & $\mathbf{2 1 , 6 9}$ & $\mathbf{2 1 , 4 3}$ & $\mathbf{1 7 , 8 9}$ & $\mathbf{2 2 , 9 1}$ \\
\hline Min. & $\mathbf{9 , 7 3}$ & $\mathbf{9 , 5 0}$ & $\mathbf{8 , 4 4}$ & $\mathbf{1 1 , 8 8}$ & $\mathbf{1 3 , 9 6}$ & 11,38 & $\mathbf{1 2 , 6 5}$ & $\mathbf{1 6 , 5 3}$ \\
\hline Maks. & $\mathbf{3 4 , 7 5}$ & $\mathbf{3 2 , 4 5}$ & $\mathbf{3 2 , 7 8}$ & $\mathbf{3 3 , 0 0}$ & $\mathbf{3 8 , 8 3}$ & $\mathbf{4 7 , 0 3}$ & $\mathbf{2 8 , 2 3}$ & $\mathbf{3 6 , 5 5}$ \\
\hline
\end{tabular}

Źródło: jak tab. 3.

Można zaobserwować, że ryzyko zmienności cen aktywów na rynku kapitałowym przybiera $\mathrm{w}$ ostatnich latach tendencję zniżkową. W większości przypadków średnia roczna zmienność w ostatnim roku analizy 2015 przyjęła wartość poniżej średniej z analizowanych 10 lat. Można zatem założyć, że po latach globalnego kryzysu 2008-2009 sytuacja na rynku kapitałowym ustabilizowała się. Czy jednak inwestorzy nie muszą obawiać się o swoje portfele aktywów finansowych? Niestety odpowiedź na to pytanie nie jest tak jednoznaczna. Pomocna może okazać się analiza współzależności zmian, jakie następują na rynkach kapitałowych zlokalizowanych w różnych częściach 
świata. Wyniki badania współczynników korelacji pomiędzy poszczególnymi indeksami giełdowymi wykazały, że wraz z upływem lat okresu analizy 2005-2015 mamy do czynienia $\mathrm{z}$ istotnym wzrostem poziomów korelacji. Innymi słowy zmiany cen aktywów na jednym rynku wpływają silnie na zmiany innych. Macierze korelacji zostały zamieszczone w tabeli 5 dla roku 2005, w tabeli 6 dla roku 2010, oraz w tabeli 7 dla roku 2015. Względem popularnego indeksu S\&P500 korelacja wzrosła odpowiednio: dla indeksu FTSE z 0,32 do 0,58; dla indeksu DAX z 0,35 do 0,51; dla indeksu Nikkei 225 z 0,03 do 0,24; dla indeksu Hnag Seng z 0,06 do 0,29; dla indeksu WIG z 0,17 do 0,46 oraz dla indeksu BUX z 0,04 do 0,26. Graficzna postać badanego zjawiska współzależności została zaprezentowana w Załączniku A.

Tabela 5. Macierz korelacji indeksów giełdowych w roku 2005

\begin{tabular}{|l|c|c|c|c|c|c|c|c|}
\cline { 2 - 9 } \multicolumn{1}{c|}{} & SPX & DJI & FTSE & GDAXI & N225 & HSI & WIG & BUX \\
\hline SPX & 1,0000 & & & & & & & \\
\hline DJI & $0,9574 *$ & 1,0000 & & & & & & \\
\hline FTSE & $0,3200 *$ & $0,3344 *$ & 1,0000 & & & & & \\
\hline GDAXI & $0,3520 *$ & $0,3764 *$ & $0,7558^{*}$ & 1,0000 & & & & \\
\hline N225 & 0,0364 & 0,0608 & $0,3252^{*}$ & $0,3280 *$ & 1,0000 & & & \\
\hline HSI & 0,0615 & 0,0608 & $0,2519 *$ & $0,2645^{*}$ & $0,5110 *$ & 1,0000 & & \\
\hline WIG & $0,1772 *$ & $0,1855^{*}$ & $0,4443 *$ & $0,3185^{*}$ & $0,2802 *$ & $0,3376 *$ & 1,0000 & \\
\hline BUX & 0,0411 & 0,0646 & $0,3538^{*}$ & $0,2396 *$ & $0,2735^{*}$ & $0,2134 *$ & $0,6554 *$ & 1,0000 \\
\hline
\end{tabular}

* poziom istotności od 0,01 .

Źródło: jak tab. 3.

Tabela 6. Macierz korelacji indeksów giełdowych w roku 2010

\begin{tabular}{|l|l|l|l|l|l|l|l|l|}
\cline { 2 - 9 } \multicolumn{1}{c|}{} & SPX & DJI & FTSE & GDAXI & N225 & HSI & WIG & BUX \\
\hline SPX & 1,0000 & & & & & & & \\
\hline DJI & $0,9825 *$ & 1,0000 & & & & & & \\
\hline FTSE & $0,6772 *$ & $0,6835 *$ & 1,0000 & & & & & \\
\hline GDAXI & $0,6786 *$ & $0,6834 *$ & $0,9113 *$ & 1,0000 & & & & \\
\hline N225 & $0,2220 *$ & $0,2401 *$ & $0,3322^{*}$ & $0,3025 *$ & 1,0000 & & & \\
\hline HSI & $0,2472 *$ & $0,2493 *$ & $0,4361 *$ & $0,3925 *$ & $0,5526 *$ & 1,0000 & & \\
\hline WIG & $0,4922 *$ & $0,4878 *$ & $0,7071 *$ & $0,7016 *$ & $0,3418^{*}$ & $0,4464 *$ & 1,0000 & \\
\hline BUX & $0,4764 *$ & $0,4918 *$ & $0,6620 *$ & $0,6559 *$ & $0,2608 *$ & $0,3793 *$ & $0,6975 *$ & 1,0000 \\
\hline
\end{tabular}

* poziom istotności od 0,01 .

Źródło: jak tab. 3. 
Tabela 7. Macierz korelacji indeksów giełdowych w roku 2015

\begin{tabular}{|c|c|c|c|c|c|c|c|c|}
\hline & SPX & DJI & FTSE & GDAXI & N225 & HSI & WIG & BUX \\
\hline SPX & 1,0000 & & & & & & & \\
\hline DJI & $0,9821 *$ & 1,0000 & & & & & & \\
\hline FTSE & $0,5835^{*}$ & $0,5824 *$ & 1,0000 & & & & & \\
\hline GDAXI & $0,5147 *$ & $0,5265 \%$ & $0,8100 *$ & 1,0000 & & & & \\
\hline N225 & $0,2480 *$ & $0,2366^{*}$ & $0,3749 *$ & $0,2561 *$ & 1,0000 & & & \\
\hline HSI & $0,2913^{*}$ & $0,2655^{*}$ & $0,4353^{*}$ & $0,3588^{*}$ & $0,4752 \%$ & 1,0000 & & \\
\hline WIG & $0,4638^{*}$ & $0,4413 *$ & $0,5896^{*}$ & $0,5494 *$ & $0,2665^{*}$ & $0,3778 *$ & 1,0000 & \\
\hline BUX & $0,2627^{*}$ & $0,2521^{*}$ & $0,4290 *$ & $0,4158 *$ & $0,2116^{*}$ & $0,3341 \%$ & $0,4841 *$ & 1,0000 \\
\hline
\end{tabular}

* poziom istotności od 0,01 .

Źródło: jak tab. 3.

\section{Podsumowanie}

Badanie miało na celu weryfikację ryzyka zmienności i współzależności pomiędzy cenami indeksów giełdowych w skali globalnej: S\&P500, Dow Jones, FTSE100, DAX, NIKKEI225, Hang Seng, WIG, BUX w latach 2005-2015. Wyniki dowiodły, że w okresie po globalnym kryzysie finansowym 2008-2009 ryzyko systematyczne, mierzone zmiennością cen aktywów na rynku kapitałowym ma charakter stabilny, natomiast zmienia się w czasie i jest coraz silniejsza współzależność pomiędzy badanymi rynkami. Badanie potwierdziło, postawianą hipotezę, że spadek zmienności indeksów giełdowych, jaki ma miejsce po globalnym kryzysie finansowym 2008-2009, nie oznacza bezpieczniejszej sytuacji dla inwestorów finansowych.

Należy zauważyć, że zjawisko zdecydowanie utrudnia możliwość stosowania skutecznej dywersyfikacji portfela inwestycyjnego. Może być to szczególne istotne dla inwestorów wybierających kraje rozwijające się jako cel alokacji kapitałów. Przenoszenie aktywów na rynki mniej rozwinięte w oczekiwaniu na wysokie stopy zwrotu, ale i wyższe ryzyko jest szczególnie niepokojące z przypadku sytuacji kryzysowych, kiedy kapitał inwestycyjny „odpływa” z rynku goszczącego.

\section{Literatura}

Adam, K., Jappelli, T., Menichini, A., Padula, M. i Pagano, M. (2002). Analyse, Compare, and Apply Alternative Indicators and Monitoring Methodologies to Measure the Evolution of Capital Markets Integration in the European Union, University of Salerno, 28 January. 
Baele, L., Fernando, A., Hordähl, P. i Krylova, E. (2004). Measuring European Financial Integration. ECB, Occasional Paper, 14.

Baltzer, M., Capiello, L., Santis, de R.A. i Manganelli, S. (2008). Measuring Financial Integration in the New EU Member States. ECB, Occasional Paper, 81.

Buch, C.M. (2004). Globalization of Financial Markets: Causes of Incomplete Integration and Consequences for Economic Policy. Berlin: Springer.

Budnikowski, A. (2006). Międzynarodowe stosunki gospodarcze. Warszawa: Polskie Wydawnictwo Ekonomiczne.

Chang, R. i Majnoni, G. (2000). International Contagion: Implications for Policy. Washington: The World Bank.

Christiansen, C., Schmeling, M. i Schrimpf, A., (2012). A comprehensive look at financial volatility prediction by economic variables. Journal of Applied Econometrics, 27(6), 956-977. Pozyskano z: http://doi.wiley.com/10.1002/jae.2298.

Eichengreen, B., Matchieson, D., Chandha, B., Jensen, A., Kodres, L. i Sharma, S. (1998). Hedge funds and financial markets dynamic. IMF Occasional Paper, 166, May.

Eichengreen, B., Rose, A.K. i Wyplosz, C. (1995). Exchange Market Mayhem: The Antecedents and Aftermath of Speculative Attacks. Economic Policy, 21, 249-312.

Eichengreen, B., Rose, A.K. i Wyplosz, C. (1996). Contagious Currency Crises. NBER Working Paper, 5681.

Elsinger, H., Lehar, A. i Summer, M. (2004). Analyzing Systemic Risk in the European Banking System: A Portfolio Approach. Uniwersytet Wiedeński. Working Paper.

Elsinger, H., Lehar, A. i Summer, M. (2006). Risk assessment for banking systems. Management Science, 52(9).

Engle, R.F. i Rangel, J.G. (2008). The Spline-GARCH Model for Low-Frequency Volatility and Its Global Macroeconomic Causes. Review of Financial Studies, 21(3), 1187-1222. Pozyskano z: https://academic.oup.com/rfs/article-lookup/doi/10.1093/rfs/hhn004.

Engle, R.F., Ghysels, E. i Sohn, B. (2013). Stock Market Volatility and Macroeconomic Fundamentals. Review of Economics and Statistics, 95 (3), 776-797. Pozyskano z: http://www.mitpressjournals. org/doi/10.1162/REST_a_00300.

Iwanicz-Drozdowska, M. (2007). Integracja rynków finansowych - jej rodzaje i znaczenie. Bank $i$ Kredyt, 1.

Karkowska, R. (2015). Ryzyko systemowe: charakter i źródta indywidualizacji w sektorze bankowym. Kraków: Wolters Kluwer.

Lowell, J., Neu, C.R. i Tong, D. (1998). Financial Crises and Contagion in Emerging Market Countries. RAND, MR-962.

Mrzygłód, U. (2011). Procesy integracyjne na rynkach kapitałowych Unii Europejskiej. Materiaty i Studia NBP, 257.

Paye, B.S. (2012), 'Déjà vol': Predictive regressions for aggregate stock market volatility using macroeconomic variables. Journal of Financial Economics, 106(3), 527-546. Available at: https:// www.sciencedirect.com/science/article/pii/S0304405X12001316.

Schuler, K. (2002). The future of dollarization in Ecuador. Guayquil: Instituto Ecuatoriano de Economia Politica.

Schwert, G.W. (1989). Why Does Stock Market Volatility Change Over Time? The Journal of Finance, 44(5), 1115-1153. Pozyskano z: http://doi.wiley.com/10.1111/j.1540-6261.1989. tb02647.x.

Sell, F.L. (2001). Contagion in Financial Markets. Cheltenham: Edward Elgar.

Solarz, J. (2008). Zarzadzanie ryzykiem system finansowego. Warszawa: Wydawnictwo PWN. 


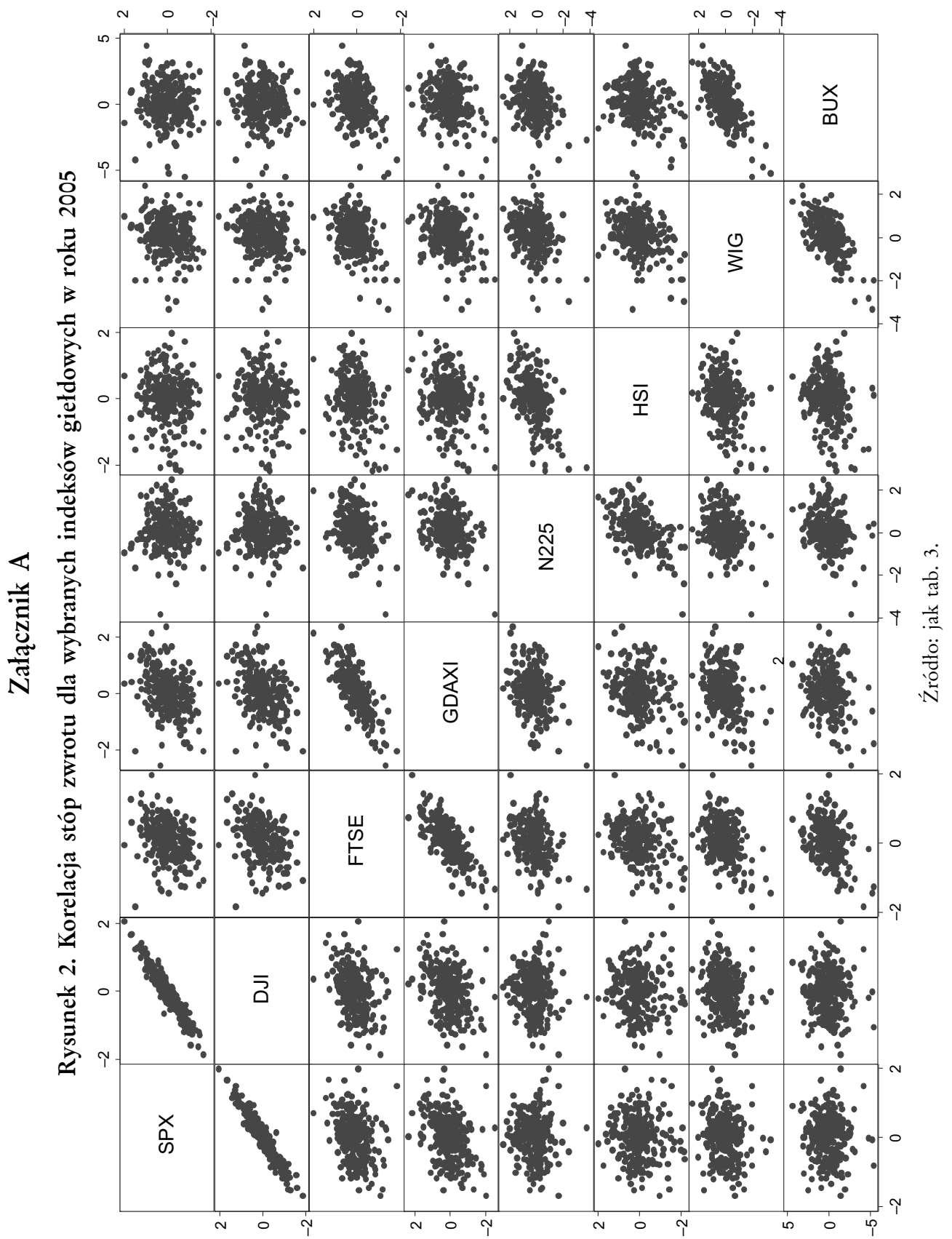




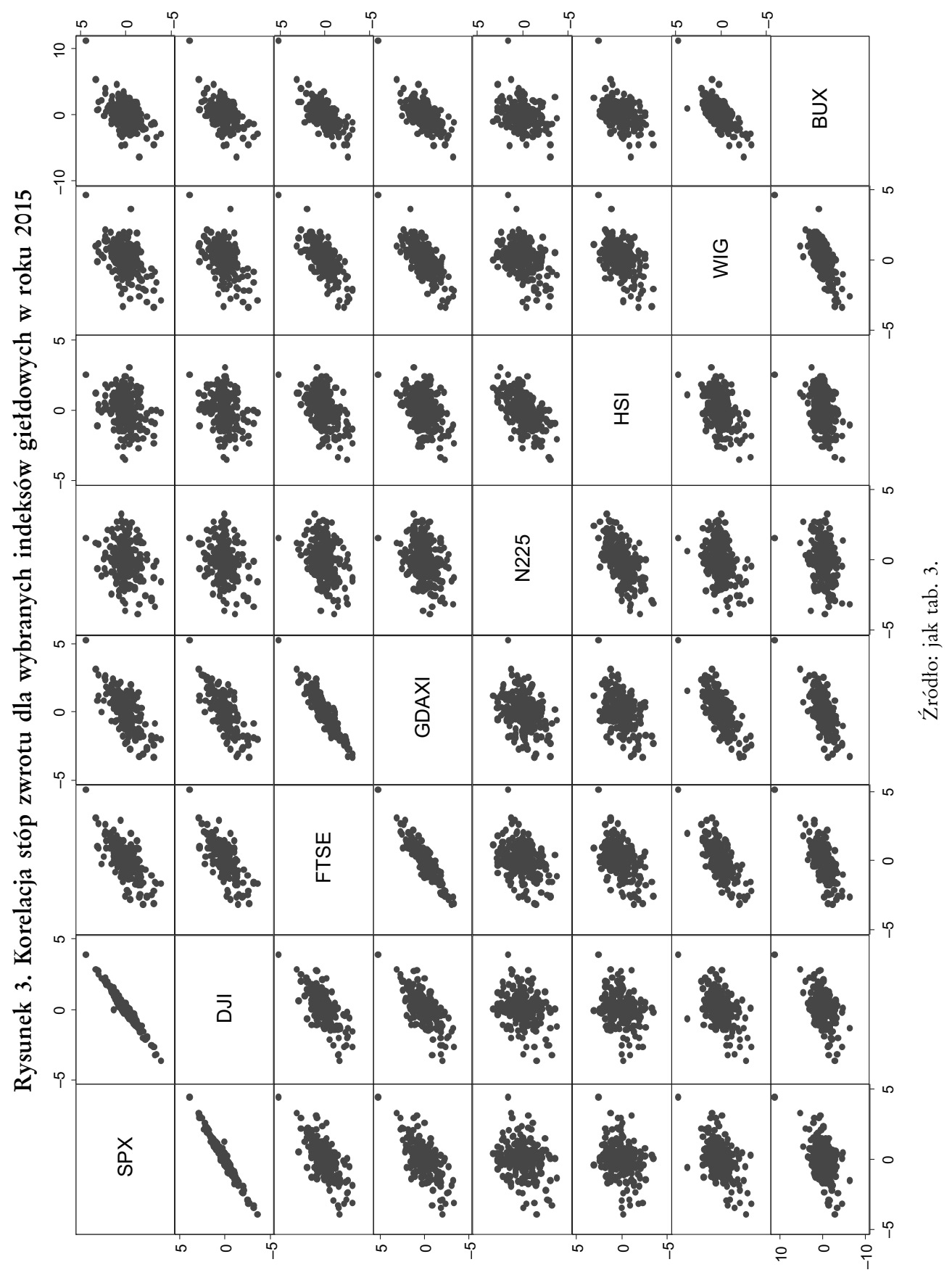





\section{MAEGORZATA OLSZAK*}

\section{Rezerwy na ryzyko kredytowe w standardach adekwatności kapitatowej}

Rozdziat podejmuje próbe badania roli rezerw na ryzyko kredytowe w standardach adekwatności kapitatowej. Z analizy wynika, że, po pierwsze, występuja istotne różnice w siatce pojęciowej w standardach adekwatności kapitatowej stosowanej w odniesieniu do strat ponoszonych przez banki na ekspozycjach kredytowych $i$ w standardach rachunkowości. Po drugie, nie ma spójności między IFRS9 i Bazylea III w zakresie szacowania oczekiwanej straty. Po trzecie, banki stosuja zróżnicowane podejście do tworzenia rezerw na ryzyko (i straty) kredytowe. To zróżnicowanie podejścia ma istotny statystycznie i ekonomicznie wptyw na związek między stopa wzrostu kredytów i wspótczynnikiem kapitatowym banku.

Słowa kluczowe: standardy adekwatności kapitałowej, rezerwy na ryzyko kredytowe, aktywność kredytowa.

\section{LOAN-LOSS PROVISIONS AND CAPITAL ADEQUACY STANDARDS}

The aim of this paper is to determine the role of loan-loss provisions in capital adequacy standards of banks. The analysis shows that there are significant differences in concepts applied to loan-loss provisions in capital adequacy standards and accounting standards. There is no common approach in the assessment of the expected loss between IAS 9 and Basel III. Banks tend to apply diversified approaches in the creation of loan-loss allowance and loan-loss provisions. This diversity significantly affects the link between loan growth and the capital adequacy ratio.

Keywords: Capital adequacy standards, loan-loss provisions, lending activity.

JEL: G21, G28, G32, M41

* Dr hab. Małgorzata Olszak - Wydział Zarządzania Uniwersytetu Warszawskiego. 


\section{Wprowadzenie}

Standardy adekwatności kapitałowej oraz standardy rachunkowości dotyczące tworzenia rezerw (lub odpisów) na straty kredytowe stanowią regulacje istotne dla praktycznej działalności banków (por. Górski, 2013, s. 174 i n. oraz s. 259). Poprzez wpływ na postrzeganie przez szeroko rozumianych interesariuszy banku ryzyka banku i jego efektywności, kształtują one wizerunek banku. Rozdział podejmuje próbę badania roli rezerw na ryzyko kredytowe w standardach adekwatności kapitałowej.

Analiza będzie koncentrować się na kilku problemach. Po pierwsze, odnosić się będzie do problemu ujęcia rezerw na ryzyko kredytowe w standardach adekwatności kapitałowej na przestrzeni całego okresu stosowania standardów adekwatności kapitałowej. Po drugie, zwróci ona uwagę na związek między metodami wyceny ekspozycji kredytowych i rezerwami na ryzyko kredytowe definiowanymi w standardach adekwatności kapitałowej. Po trzecie, poszukiwać będzie odpowiedzi na pytanie, co mówią badania empiryczne o roli rezerw na ryzyko kredytowe dla związku między aktywnością kredytową i adekwatnością kapitałową banku. W opracowaniu, biorąc pod uwagę specyfikę problemów w nim sformułowanych, posłużono się analizą krytyczną dokumentów i wcześniejszych prac badawczych.

Dalsza część opracowania składa się z trzech sekcji, z których pierwsza (punkt 2) dotyczy ewolucji standardów adekwatności kapitałowej. Kolejna sekcja (3) obejmuje prezentację specyfiki rezerw na ryzyko kredytowe według standardów adekwatności kapitałowej i standardów rachunkowości i wskazuje na istotne różnice w ujmowaniu strat kredytowych widoczne we współcześnie stosowanych standardach. W sekcji tej przedstawiono również najważniejsze wnioski płynące z badań nad rolą podejścia stosowanego przez banki do tworzenia rezerw na ryzyko kredytowe $\mathrm{w}$ związku między aktywnością kredytową i adekwatnością kapitałową. Ostatnia sekcja zawiera wnioski końcowe.

\section{O ewolucji standardów adekwatności kapitałowej}

\subsection{Od Bazylei I do Bazylei II}

Standardy adekwatności kapitałowej jako regulacyjne narzędzie tworzenia równych warunków gry są obecne w międzynarodowym sektorze bankowym od trzydziestu lat. Pierwsza uzgodniona wersja tych standardów, zwana Bazyleą I, została przyjęta przez Bank Rozrachunków Międzynarodowych 
w 1988 roku. Była ona rozwiązaniem nowatorskim w tamtym okresie - przynajmniej w ujęciu regulacyjnym ${ }^{1}$. $Z$ perspektywy teoretycznej rozwiązywała ona przynajmniej część problemu pokusy nadużyć (moral hazard), która cechuje relacje między akcjonariuszami banku (inwestorami) i deponentami (jako wierzycielami) i wynika $\mathrm{z}$ funkcjonowania systemu gwarantowania depozytów. Akcjonariusze banku - mając świadomość niskiej zdolności drobnych deponentów do nadzorowania ryzyka banku (tym bardziej, że drobne depozyty posiadają ubezpieczenie w publicznym systemie gwarantowania), mają skłonność do podejmowania decyzji inwestycyjnych, których ryzyko nie jest $\mathrm{w}$ pełni odzwierciedlone $\mathrm{w}$ poziomie oprocentowania depozytów. Idea tego standardu sprowadzała się do wprowadzenia stałej relacji między kapitałami własnymi banku i ważonymi ryzykiem aktywami i pozycjami pozabilansowymi. Według oczekiwań Bazylei I taka stała relacja powinna wynosić $8 \%$.

Kolejne lata po przyjęciu oryginalnego tekstu Bazylei I to okres doskonalenia (i co za tym idzie znacznego rozbudowywania) standardu, by uwzględnić w nim coraz szersze spektrum ryzyka (por. Olszak, 2009a, s. 21 i n.). O ile w pierwotnej wersji Bazylea I pokrywała wyłącznie skutki ryzyka kredytowego, to już poprawka wprowadzona w 1996 roku, nakazywała bankom utrzymywanie kapitałów, które pokryją straty związane z ryzykiem rynkowym (zarówno cenowym, jak i specyficznym). Pod koniec lat 90. XX wieku, uznano jednak, że konieczne jest dalsze rozwijanie tych standardów adekwatności kapitałowej, w celu zapewnienia im zdolności do większej wrażliwości na ryzyko (co odnosiło się szczególnie do ryzyka kredytowego), oraz uwzględnienia pomijanego przez lata, a istotnego z perspektywy stabilnego działania banku, ryzyka operacyjnego. W pracach nad tymi standardami dążono również do jak najlepszego uwzględnienia osiągnięć nauki (zarówno w sferze teoretycznej, jak i empirycznej) i techniki (postęp w zakresie zastosowania komputerów i oprogramowania statystycznego do analizy ryzyka), w pomiarze ryzyka kredytowego (por. Olszak, 2009a, s. 25 i n. oraz Olszak 2015, s. 134 i n.). Efektem tych prac było uzgodnienie w 2004 roku finalnej wersji Bazylei II, która została zaprezentowana w jednym dokumencie w 2006 roku (por. BCBS, 2006). Nowatorskość Bazylei II polegała na wprowadzeniu trzech filarów pomiaru adekwatności kapitałowej banków. Przy czym pierwszy filar obejmował pomiar minimalnego poziomu kapitału regulacyjnego,

1 Z niektórych opracowań dotyczących okresu wdrożenia Bazylei I wynika, że ten międzynarodowy standard przyjęto m.in. by zmniejszyć udział banków japońskich w rynkach kredytowych grupy G10, a szczególnie amerykańskim rynku kredytowym (por. Olszak, 2009a, s. 20 i n.). 
niezbędnego do pokrycia nieoczekiwanych strat w działalności banku. Filar drugi dotyczył oceny nadzorczej procesu pomiaru adekwatności kapitałowej banków. Z kolei filar trzeci koncentrował się na takim pomiarze adekwatności kapitałowej, który będzie wynikał z oceny szeroko rozumianych interesatriuszy banku². Warto jednak zauważyć, że Bazylea II utrzymała w mocy minimalnym poziom współczynnika adekwatności kapitałowej na poziomie $8 \%$.

Generalnie w filarze I Bazylei II, w odróżnieniu od Bazylei I, w standardzie z 2004 r. wprowadzono wrażliwość wag ekspozycji kredytowych na ryzyko kredytowe. Skala tej wrażliwości zależała od metody (standardowej, Standardised approach, SA, lub wewnętrznych ratingów, Internal ratings based approach, IRB) pomiaru ekspozycji na ryzyko kredytowe. W przypadku metody standardowej waga ta zależała od ratingu kredytowego (credit rating) zewnętrznego nadanego przez tzw. uznaną agencję ratingową (por. Olszak, 2009a, s. 38 i n.). Stąd $\mathrm{z}$ założenia różnicowanie wag $\mathrm{w}$ zależności od ratingu kredytowego mogło dotyczyć tych aktywów banku, których dłużnicy mieli nadany rating kredytowy (tj. głównie ekspozycji wobec rządów i podmiotów instytucjonalnych, posiadających osobowość prawną) i nie mogło dotyczyć ekspozycji detalicznych, tj. np. kredytów konsumpcyjnych lub kredytów hipotecznych udzielonych osobom fizycznym. Te ostatnie ekspozycje miały ustalone jednolite stałe wagi ryzyka kredytowego (por. Olszak, 2015, s. 158 i 159).

Natomiast w przypadku metody wewnętrznych ratingów, wagi ryzyka były (i nadal są) bardzo zróżnicowane (maksymalny ich poziom to $1250 \%$, podobnie jak w przypadku metody standardowej) i zależą od ratingu kredytowego ustalonego $\mathrm{w}$ procesie oceny zdolności kredytowej banku.

Jak już podkreślano, do istotnych nowości, wprowadzonych przez standard Bazylea II, należy również zaliczyć podniesienie rangi dialogu między bankiem (jako podmiotem nadzorowanym) oraz nadzorca - co zostało uwzględnione w tzw. filarze drugim Bazylei II, o nazwie „Proces przeglądu nadzorczego" (Supervisory Review Process) 3 oraz szeroko rozumianymi interesariuszami banku - co zostało uwzględnione w tzw. filarze trzecim Bazylei II, o nazwie „Dyscyplina rynkowa”. Głównym celem filaru II było zapewnienie, że bank posiada kapitał własny adekwatny do pokrycia skutków tego ryzyka, które nie jest uwzględnione w filarze I, a które może mieć istotny wpływ na bezpieczeństwo funkcjonowania banku. Przyjęto, że nadzór publiczny (państwowy) nad bankiem, jest kompetentny do tego, aby

2 Podkreślenia wymaga fakt, że Bazylea I odnosiła się jedynie do pomiaru minimalnych wymogów kapitałowych, a zatem w istocie sprowadzała się do filaru I Bazylei II.

3 W Polsce nadzór publiczny nad bankami realizuje założenia tego procesu w tzw. BIONie (Badaniu i Ocenie Nadzorczej). 
wesprzeć bank w doskonaleniu wewnętrznego procesu adekwatności kapitałowej (tzw. ICAAP, Internal Capital Adequacy Assessment Process). Natomiast Filar III, miał skłaniać bank do zwiększenia przejrzystości działania, poprzez ujednolicenie zakresu i sposobu publikacji informacji o adekwatności kapitałowej banku, w efekcie obawy o pogorszenie ratingu zewnętrznego bank miał dobrowolnie utrzymywać bufor kapitałowy ( $\mathrm{t} j$. nadwyżkę kapitału ponad minimum wynikające z Filaru I i II $)^{4}$.

\subsection{Bazylea III jako odpowiedź na kryzys finansowy 2007-2008}

W efekcie negatywnych następstw dla sfery realnej ostatniego Globalnego Kryzysu Finansowego, Komitet Bazylejski istotnie zrewidował (i zaostrzył) standardy adekwatności określone w Bazylei II. Zmiany te miały wymiar mikroostrożnościowy i makroostrożnościowy, co powinno dać w efekcie nie tylko stabilne finansowo pojedyncze banki, lecz także stabilny i bezpiecznych sektor bankowy (i finansowy) i dotyczyły głównie filaru I (tj. pomiaru adekwatności kapitałowej). Z perspektywy mikroostrożnościowej (por. Olszak, 2011; 2015, s. 403 i n.; Olszak i Olszak, 2014): (1) zaostrzono kryteria doboru składu kapitałów własnych, szczególnie kapitału pierwszej kategorii (tzw. Tier 1) i kapitału zwykłego (tzw. CET 1, Common Equity tier 1); (2) podwyższono poziom minimalnego współczynnika kapitałowego CET 1 (z 2 do 4,5\%) i Tier 1 (z 4 do 6\%); (3) obniżono znaczenie kapitału drugiej kategorii; (4) wprowadzono wskaźnik dźwigni, będący relacją kapitału pierwszej kategorii do sumy aktywów i pozycji pozabilansowych i wynoszący minimum 3\%; (5) powiązano standardy adekwatności kapitałowej z pomiarem ryzyka płynności, poprzez wprowadzenie wskaźnika pokrycia płynności (LCR) oraz wskaźnik stabilnego finansowania (NSFR) (por. Olszak i Olszak, 2014).

Natomiast z perspektywy makroostrożnościowej, wprowadzono m.in. antycykliczny bufor kapitałowy oraz dodatkowe obciążenie kapitałowe dla instytucji finansowych istotnych systemowo (por. Olszak, 2015, s. 420-423). Wskaźnik dźwigni, ze względu na jego zdolność do ograniczania skali ryzyka ogółem banku, jest również uznawany, na równi z LCR i NSFR, za narzędzie sterowania ryzykiem systemowym (Olszak, 2015, s. 419).

Zatem współcześnie standardy adekwatności kapitałowej, stanowią regulację, która ma na celu zapewnienie stabilnego działania pojedynczych ban-

\footnotetext{
4 Proces ten nawiązywał do wyników badań nad rolą dyscypliny rynkowej w bankowości (por. Olszak, 2009b).
} 
ków oraz stabilnego sektora bankowego. Potencjał makroostrożnościowy standardów kapitałowych został potwierdzony w badaniach empirycznych (por. badanie Olszak i in., 2016 i 2018 oraz cytowaną tam literaturę).

\section{Dlaczego rezerwy na ryzyko mają istotne znaczenie dla działania standardów kapitałowych banków}

\subsection{Rezerwy na ryzyko kredytowe w umowach bazylejskich I, II i III}

Rezerwy na ryzyko kredytowe mają istotne znaczenie dla kształtowania się adekwatności kapitałowej banków. Bazylejskie standardy adekwatności kapitałowej (tj. zarówno tzw. Bazylea I, II, jak i III) wyróżniają dwie kategorie rezerw na ryzyko kredytowe banków, tj. rezerwy ogólne (general provisions) oraz rezerwy specyficzne (specific provisions) ${ }^{5}$. Rezerwy ogólne są utrzymywane w celu pokrycia przyszłych strat, które nie zostały zidentyfikowane $\mathrm{w}$ chwili ich tworzenia, ale które z dużym prawdopodobieństwem mogą ujawnić się w krótkim horyzoncie czasowym (por. np. BIS, 2017, s. 2). Natomiast rezerwy specyficzne dotyczą tych aktywów i pozycji pozabilansowych, ujmowanych zarówno indywidualnie (tj. takich, które w sensie ekonomicznym są indywidualnie istotne ${ }^{6}$ ), jak i grupowo, które dotknęło pogorszenie jakości kredytowej związane m.in. z opóźnieniem kredytobiorcy w spłacie długu. Rezerwy ogólne, zgodnie z Bazyleą I oraz metodą standardową Bazylei II i III, mogą być zaliczone do kapitałów własnych drugiej kategorii (tzw. Tier 2) do poziomu nieprzekraczającego 1,25\% ekspozycji kredytowych ważonych ryzykiem. Rezerwy specyficzne nie mogą być włączone do kapitałów własnych i pomniejszają wartość ekspozycji kredytowych, które mają być mnożone przez wagi ryzyka. Natomiast rezerwy ogólne są uwzględnione w poziomie ekspozycji kredytowej’

W przypadku metody wewnętrznych ratingów (zarówno w Bazylei II, jak i III), całkowita kwota rezerw na ryzyko kredytowe (tzw. Total eligible provisions) obejmuje szeroką grupę strat kredytowych poniesionych faktycznie i takich, które mogą być poniesione, tj.: rezerwy specyficzne (w ujęciu

5 Por. np. par. 49 (iv) do 49(x) w dokumencie znanym jako Bazylea II (BIS, 2006).

6 Podział taki wprowadzony został w MSR39.

$7 \mathrm{Ta}$ cecha nadaje im charakter zbliżony do rezerw na ryzyko ogólne tworzonych przez banki stosujące Polskie Standardy Rachunkowości (por. Olszak, 2015, s. 150). Jednakże w świetle polskiego wdrożenia standardów adekwatności kapitałowej rezerwy na ryzyko ogólne nie mogły być zaliczane do kapitałów Tier 2 (tzw. kapitały uzupełniające). 
indywidualnym i grupowym), częściowe odpisy, rezerwy ogólne w ujęciu portfelowym, inne rezerwy ogólne oraz dyskonta wartości aktywów, które dotknięte zostały niewypłacalnością dłużnika. Z kwoty tych rezerw są wyłączone rezerwy specyficzne utworzone na utratę wartości ekspozycji wynikających $\mathrm{z}$ inwestycji banku w akcje oraz ekspozycje sekurytyzacyjne.

Poziom całkowitej kwoty rezerw na ryzyko kredytowe w przypadku metody IRB zależy od regulacyjnego pomiaru ${ }^{8}$ wysokości oczekiwanej straty (Expected Loss, EL) właściwej ekspozycji kredytowej, będącej iloczynem prawdopodobieństwa niewykonania zobowiązania przez dłużnika (probability of default, PD), współczynnika straty w momencie niewykonania zobowiązania (loss given defalut, LGD) oraz wartości ekspozycji kredytowej w momencie niewykonania zobowiązania (exposure at default, EAD). W przypadku gdy całkowita kwota rezerw na ryzyko kredytowe jest niższa niż regulacyjny pomiar EL, różnica między obiema kwotami jest odejmowana od kapitału CET1 (bez uwzględnienia efektu podatkowego). Natomiast każda nadwyżka całkowitej kwoty rezerw na ryzyko kredytowe ponad regulacyjny pomiar EL jest dodawana do kwoty kapitału drugiej kategorii (Tier 2), do poziomu nie wyższego niż $0.6 \%$ ekspozycji ważonej ryzykiem kredytowym według metody IRB. Ekspozycja ważona ryzykiem kredytowym w przypadku metody IRB jest ekspozycją brutto i obejmuje wszystkie rezerwy tak specyficzne, jak i ogólne.

Zauważyć należy, że w praktyce stosowania standardów adekwatności kapitałowej na świecie, widoczne jest istotne zróżnicowanie w zakresie uwzględniania rezerw na ryzyko kredytowe w kapitałach własnych (por. BCBS, 2016 i 2017; Olszak i in., 2017a). Nawet w obrębie Unii Europejskiej, pomimo stosowania jednolitych dyrektyw dotyczących sektora bankowego, nie ma w tym zakresie jednorodności (por. Olszak i in., 2017a).

\subsection{Rezerwy na ryzyko kredytowe w umowach bazylejskich a standardy rachunkowości}

Wprawdzie rezerwy na ryzyko kredytowe oddziałują na adekwatność kapitałową banków, to jednak nie istnieje wspólna siatka pojęciowa między standardami ostrożnościowymi banków oraz standardami rachunkowości w tym zakresie. Każdy z tych standardów posiada bowiem swój zestaw pojęć i definicji tych pojęć. Oznacza to zatem, pewien stopień uznaniowości banków

8 Sformułowanie „regulacyjny pomiar”, wskazuje na pomiar zgodnie z wymogami regulatora (co jest określone w przepisach prawa) i pozwala na odróżnienie bankowego sposobu oceny oczekiwanej straty, który może odbiegać istotnie od regulacyjnego oszacowania. 
(i władz ich nadzorujących lub twórców regulacji bankowych) w zakresie tworzenia poszczególnych kategorii rezerw na ryzyko kredytowe. Standardy rachunkowości w tym obszarze przede wszystkim stanowią propozycję wyceny ekspozycji kredytowych. Tutaj odniosę się do tych, które są przechowywane w księgach bankowych, bo właśnie te ekspozycje odgrywają istotną rolę $\mathrm{w}$ kształtowaniu się ryzyka systemowego i są uwzględniane $\mathrm{w}$ polityce makroostrożnościowej (szczególnie tej antycyklicznej) (por. Olszak, 2015).

Zauważyć należy, że wycena instrumentów finansowych, które tworzą ekspozycję na ryzyko banku jest bardzo istotna z kilku powodów. Przede wszystkim jest ona wykorzystywana przy opracowywaniu raportów i sprawozdań finansowych banków oraz służy jako ważna zmienna wejściowa do pomiaru ryzyka. Efekty pomiaru ryzyka - odpowiednio opracowane w postaci miar i wskaźników - są również zamieszczane w odpowiednich raportach finansowych banków. Informacja finansowa opracowana przez bank na podstawie danych wynikających z wyceny trafia na rynki finansowe różnymi kanałami i staje się narzędziem dyscyplinowania działalności banków przez uczestników rynków - tzw. szeroko rozumianych interesariuszy banków. Informacja ta staje się dla kadry zarządzającej bankiem jedną z podstawowych determinant decyzji inwestycyjnych. Jak widać więc, wycena jest jednym z kluczowych czynników oddziałujących na działalność banku (Olszak, 2015, s. 202).

Metoda pomiaru rezerw na ryzyko kredytowe oraz zasady ich uwzględniania $\mathrm{w}$ bilansie mają istotne znaczenie z perspektywy kondycji kapitałowej banków, ze względu na to, że konieczność utworzenia rezerwy oddziałuje na poziom kapitałów własnych. Rezerwy specyficzne pomniejszają poziom dochodów banków i w efekcie poziom kapitałów własnych o kwotę w przybliżeniu równą iloczynowi rezerw specyficznych netto (tj. różnicy między kwotą utworzonej rezerwy specyficznej i rozwiązanej rezerwy specyficznej w okresie rozrachunkowym) oraz liczbie 1 pomniejszonej o wysokości stopy podatkowej.

Natomiast jeżeli banki w danym kraju są zobligowane do tworzenia rezerw generalnych, to ich sposób wpływu na poziom kapitałów własnych zależy od tego czy i jak są one uwzględniane w kapitałach. Jeżeli kwota utworzonej w danym okresie rezerwy generalnej wchodzi w skład kapitałów własnych to wtedy przyrost kapitałów własnych jest równy kwocie utworzonej rezerwy generalnej pomnożonej przez stopę opodatkowania ${ }^{9}$. Natomiast jeżeli kwota

9 Wynika to z tego, że zysk netto banku jest uzyskiwany z iloczynu zysku brutto i (1-stopa opodatkowania). A zysk brutto równy jest dochodom operacyjnym banku pomniejszonym o kwotę rezerw specyficznych i rezerw generalnych. 
rezerwy generalnej nie jest włączana do kapitałów własnych, to wtedy poziom kapitałów własnych jest korygowany o kwotę równą iloczynowi utworzonej w danym okresie rezerwy generalnej i (1-stopa opodatkowania).

Standardy rachunkowości w zakresie wyceny ekspozycji kredytowych podlegają ewolucji, choć nie tak dynamicznej, jak regulacje bankowe w zakresie adekwatności kapitałowej. Odnosząc się do polskiego sektora bankowego, można zauważyć, że model szacowania utraty wartości ekspozycji kredytowych ulegał wielu zmianom w ostatnim trzydziestoleciu (por. Olszak, 2015, s. 219 i n.). Do roku 2004 banki mogły identyfikować ekspozycje przeterminowane (co jest niezbędne do określenia rezerw specyficznych, zdefiniowanych w standardach adekwatności kapitałowej) przy użyciu tzw. Polskich Standardów Rachunkowości (tzw. PSR-y) - co w ujęciu technicznym było opisane w rozporządzeniu Ministra Finansów ${ }^{10}$. Natomiast od przełomu roku 2004/2005 banki mogły przejść na stosowanie Międzynarodowych Standarów Rachunkowości (tzw. MSR-y) (por. Olszak, 2011). W okresie 2004-2017 kwestie tworzenia odpisów z tytułu utraty wartości ekspozycji kredytowych regulował MSR 3911. W myśl MSR 39 (dalej: IFRS 39) banki tworzą jedynie odpisy tytułu utraty wartości aktywów wynikające ze strat faktycznie poniesionych, co pozwala zidentyfikować rezerwy specyficzne (istotne z perspektywy pomiaru adekwatności kapitałowej). Zatem nie istnieje w myśl tego standardu kategoria oczekiwanych strat $\mathrm{i}$ oczywiście nie ma w nich miejsca na rezerwy ogólne, które mogłyby być włączone do kapitału Tier 2.

Natomiast od stycznia 2018 roku IFRS 39 został zastąpiony IFSR 912, który ma rozwiązać problem potencjalnej procykliczności metod wyceny księgowej ekspozycji kredytowych (por. Olszak, 2015, s. 434-437). W standardzie tym, model poniesionej faktycznie straty na ekspozycjach kredytowych i odpisów został zastąpiony tzw. modelem oczekiwanej straty kredytowej (expected credit loss model, ECL). Nowy model szacowania rezerw na straty oczekiwane wymaga od banku rozpoznawania oczekiwanych strat $\mathrm{w}$ każdym momencie raportowania $\mathrm{w}$ celu uwzględnienia zmian w ryzyku kredytowym instrumentu finansowego. W odróżnieniu od MSR

${ }_{10}$ W latach 90. XX wieku było to Zarządzenie Prezesa NBP i Uchwała Komisji Nadzoru Bankowego (por. Olszak, 2015, s. 220-221).

11 Oczywiście nie wszystkie banki stosują od tego momentu MSR 39. Bardzo duża grupa banków spółdzielczych pozostała przy PSR-ach.

12 MSR 9 został zaproponowany przez International Accounting Standards Board (IASB), którego standardy są stosowane w wielu krajach, z wyjątkiem Stanów Zjednoczonych. W Stanach Zjednoczonych standard zbliżony w istocie do MSR 9, zaproponował US Financial Accounting Standards Board (FASB). 
39, jest to model uwzględniający potencjalne następstwa przyszłych zdarzeń (tzw. forward-looking). W szczególności, decyzja o utworzeniu rezerwy nie jest uzależniona od wystąpienia zdarzenia istotnie wpływającego na wartość ekspozycji kredytowej, jak również bank może uwzględniać informacje historyczne, bieżące oraz wynikające z prognoz.

\section{Specyfika pomiaru utraty wartości wedtug IFRS 9 a standardy adekwatności kapitałowej}

W tabeli 1 przedstawiono sposób szacowania oczekiwanej straty według IFRS $9 \mathrm{w}$ zależności od jakości kredytowej ekspozycji. W okresie trwania ekspozycji (tj. od momentu udzielenia kredytu do jego spłaty) wyodrębnić można trzy etapy. W pierwszym znajdują się ekspozycje, które zostały nowo utworzone, a więc $\mathrm{w}$ odniesieniu do nich nie widać objawów pogorszenia jakości kredytowej. W odniesieniu do tych ekspozycji bank zobligowany jest do szacowania 12-miesięcznej oczekiwanej straty równej iloczynowi ekspozycji przez prawdopodobieństwo niewykonania zobowiązania (PD) i współczynnik straty na ekspozycji kredytowej (LGD). Wartość tak utworzonej straty jest kosztem w rachunku zysków i strat banku. Strata ta nie pomniejsza wartości ekspozycji kredytowej, lecz jest włączana do bilansu (w pasywach) jako kwota rezerwy na ryzyko kredytowe (tzw. loan loss allowance). Ten rodzaj oczekiwanej straty można utożsamiać z oczekiwaną stratą zdefiniowaną $\mathrm{w}$ rozdziale 1 ( $\mathrm{w}$ sensie ekonomicznym) i rezerwą generalną (w sensie finansowym). Metoda pomiaru tej straty w wersji zaproponowanej przez IASB w IFRS 9 nie pozwala na uchwycenie niedociągnięć pomiaru ryzyka, o których była mowa $\mathrm{w}$ rozdziale 3 . Biorąc bowiem pod uwagę wnioski płynące $\mathrm{z}$ analizy zawartej $\mathrm{w}$ rozdziale 3 - w szczególności to, że wartości PD i LGD są zmiennymi stochastycznymi, skorelowanymi ze sobą, należałoby dążyć do tego, aby kwota oczekiwanej straty była wyższa, niż wynika to z prostego iloczynu parametrów ryzyka kredytowego. W ten sposób bank mógłby gromadzić wyższą kwotę rezerw w fazie wzrostowej cyklu koniunkturalnego (oraz finansowego) i niższą w okresie spadkowej, co prowadziłoby do stabilizacji dochodów i mogłoby - w świetle wniosków płynących z rozdziału 6 - ograniczać procykliczny wpływ kapitałów własnych na aktywność kredytową.

Pozostałe dwa etapy dotyczą ekspozycji, w odniesieniu do których istnieją przesłanki do uznania ich za tracące wartość. Na drugim etapie znajdują się ekspozycje, w odniesieniu do których odnotowano przypadki pogorszenia jakości kredytowej, np. ze względu na pogorszenie uwarunkowań ekonomicznych funk- 
cjonowania branży, której inwestycje są finansowane przez bank. W odniesieniu do tych ekspozycji tworzona jest kwota rezerwy (przy zastosowaniu podejścia indywidualnego lub kolektywnego, zbliżonego $\mathrm{w}$ istocie to funkcjonującego w MSR 39 podejścia szacowania strat dla ekspozycji włączonych do grupy tzw. IBNR (identified but not reported loss, zidentyfikowane, ale nie zaraportowane straty) - nazywanej oczekiwaną stratą na okres pozostały do końca terminu zapadalności. Jeżeli ustaną przesłanki wskazujące na wzrost ryzyka niewykonania zobowiązania przez dłużnika, ekspozycja ta wraca do etapu 1.

Natomiast na etapie trzecim znajdują się ekspozycje kredytowe, które ze względu na zaprzestanie wykonania zobowiązań przez kredytobiorcę, bank musi uznać za niepracujące i spisać w straty kredytowe.

Tabela 1. Rodzaje oczekiwanych strat na ekspozycjach kredytowych wycenianych według zamortyzowanego kosztu w myśl standardu IFRS 9

\begin{tabular}{|c|c|c|}
\hline \multicolumn{3}{|c|}{ Rodzaj rozpoznawanych oczekiwanych strat } \\
\hline $\begin{array}{l}\text { 12-miesięczne oczekiwane } \\
\text { straty }\end{array}$ & $\begin{array}{c}\text { oczekiwane straty na okres } \\
\text { pozostały do terminu } \\
\text { zapadalności }\end{array}$ & $\begin{array}{c}\text { oczekiwane straty na okres } \\
\text { pozostały do terminu } \\
\text { zapadalności }\end{array}$ \\
\hline \multicolumn{3}{|c|}{ sposób uwzględniania dochodów odsetkowych } \\
\hline $\begin{array}{l}\text { efektywne odsetki naliczane od } \\
\text { wartości brutto ekspozycji }\end{array}$ & $\begin{array}{l}\text { efektywne odsetki naliczane od } \\
\text { wartości brutto ekspozycji }\end{array}$ & $\begin{array}{l}\text { efektywne odsetki naliczane } \\
\text { od wartości netto ekspozycji } \\
\text { (pomniejszonej o kwotę straty) }\end{array}$ \\
\hline etap 1: & etap 2: & etap 3: \\
\hline ekspozycje pracujące & ekspozycje pod obserwacją & ekspozycje zagrożone \\
\hline $\begin{array}{l}\text { ujęcie początkowe - aktywa bez } \\
\text { utraty wartości i bez wysokiego } \\
\text { ryzyka kredytowego }\end{array}$ & $\begin{array}{l}\text { aktywa, w przypadku których } \\
\text { zanotowano znaczny wzrost } \\
\text { ryzyka kredytowego w porów- } \\
\text { naniu do ujęcia początkowego }\end{array}$ & $\begin{array}{l}\text { aktywa, których jakość kredy- } \\
\text { towa znacząco się pogorszyła }\end{array}$ \\
\hline
\end{tabular}

Źródło: Olszak, 2015, s. 436.

Jak słusznie podkreśla Komitet Bazylejski (BCBS, 2015, s. 16), porównanie modelu ECL i metody szacowania EL w przypadku banków stosujących IRB prowadzi do identyfikacji istotnych różnic w zakresie pomiaru oczekiwanej straty (a zatem rezerw ogólnych) oraz straty poniesionej (a zatem rezerw specyficznych). Różnice te dotyczą przede wszystkim kredytów pracujących (na etapie 1) oraz kredytów wchodzących w strefę zagrożenia brakiem spłaty 
(na etapie 2). W przypadku kredytów nowo udzielonych, PD jest oszacowywane dla okresu 12 miesięcy zarówno w ECL, jak i IRB, ale występują różnice w szacunku LGD i EAD (por. tab. 2). Natomiast w przypadku kredytów zagrożonych brakiem spłaty (etap $2 \mathrm{w}$ tab. 1) banki określają PD dla całego okresu trwania umowy kredytowej, co oznacza znaczny wzrost poziomu rezerw na ryzyko kredytowe (w porównaniu z rozwiązaniami określonymi w MSR 39 czy też PSR). W efekcie wpłynie to istotnie na adekwatność kapitałową banków, ograniczając poziom wskaźników kapitałowych banków. By zapobiec problemowi zagrożenia wypłacalności banków w związku z przejściem na model ECL, Komitet Bazylejski (2017) zaproponował standard pozwalający bankom na stopniowe aplikowanie rozwiązań ECL do szacunków adekwatności kapitałowej (por. też EBA, 2016).

Tabela 2. Porównanie ujmowania pracujących i niepracujących ekspozycji kredytowych w IFRS 9 i w metodzie IRB w standardach adekwatności kapitałowej

\begin{tabular}{|c|c|c|c|}
\hline $\begin{array}{c}\text { Parametr } \\
\text { ryzyka } \\
\text { kredytowego }\end{array}$ & $\begin{array}{l}\text { Kryterium } \\
\text { porównania }\end{array}$ & IFRS 9 & Bazylea III \\
\hline \multirow[b]{2}{*}{ PD } & $\begin{array}{l}\text { okres wybrany do } \\
\text { szacowania PD }\end{array}$ & $\begin{array}{l}12 \text { miesięcy (na etapie } 1 \text { ) } \\
\text { cały okres pozostały do końca } \\
\text { umowy kredytowej (na etapie } 2 \text { ) }\end{array}$ & 12 miesięcy \\
\hline & $\begin{array}{l}\text { wrażliwość na cykl } \\
\text { koniunkturalny }\end{array}$ & $\begin{array}{l}\text { ocena PD ma charakter bieżą- } \\
\text { cy (tzw. Point-in-Time, PiT"), } \\
\text { uwzględniającej wyprzedzająca (for- } \\
\text { ward - looking) informację, w tym } \\
\text { czynniki makroekonomiczne }\end{array}$ & $\begin{array}{l}\text { oszacowanie z pełnego } \\
\text { cyklu koniunkturalnego }\end{array}$ \\
\hline LGD/EAD & metoda pomiaru & $\begin{array}{l}\text { neutralne oszacowanie, uwzględ- } \\
\text { niające wyprzedzającą (forward - } \\
\text { looking) informację, w tym czynniki } \\
\text { makroekonomiczne }\end{array}$ & $\begin{array}{l}\text { oszacowanie z okresu } \\
\text { spowolnienia gospo- } \\
\text { darczego }\end{array}$ \\
\hline
\end{tabular}

"Wyjaśnienie pojęcia PiT można znaleźć w: Olszak (2015).

Źródło: BCBS, 2016, s. 16.

\subsection{Rezerwy na ryzyko kredytowe a związek między aktywnością kredytową banków i wskaźnikiem kapitałowym w świetle badań empirycznych}

Z rozważán przedstawionych w poprzednich punktach wynika, że rezerwy na ryzyko kredytowe oddziałują na adekwatnośc kapitałową banku, a nie tylko aktywność kredytową. Z badań empirycznych wiadomo, że aktywność 
kredytowa również jest kształtowana przez standardy adekwatności kapitałowej (por. Olszak, 2009a i 2015). Nasuwa się zatem pytanie, co mówią badania empiryczne na temat wpływu rezerw na ryzyko kredytowe na związek między aktywnością kredytową i współczynnikiem kapitałowym (czy też współczynnikiem adekwatności kapitałowej). Badania w tym zakresie nie są liczne. Dotyczą one Stanów Zjednoczonych (por. Beatty i Liao, 2011), Unii Europejskiej (por. Olszak i in., 2015) oraz Polski (Olszak i in., 2017).

Z badań przeprowadzonych przez Beatty i Liao (2011) wynika, że aktywność kredytowa dużych banków, które z opóźnieniem tworzą rezerwy na straty kredytowe, jest bardziej wrażliwa na współczynnik adekwatności kapitałowej, szczególnie w okresie recesji. Oznacza to, że duże banki, które opóźniają tworzenie rezerw, mają większe trudności z rozwijaniem akcji kredytowej ze względy na wskaźnik kapitałowy niż banki, które tworzą więcej rezerw z wyprzedzeniem.

Olszak i in. (2015) badają wpływ wygładzania dochodów (income-smoothing $)^{13}$ przy użyciu rezerw na ryzyko kredytowe oraz wpływ wrażliwości rezerw na cykl koniunkturalny (tzw. procykliczność) na związek między stopą wzrostu kredytów i współczynnikiem kapitałowym w dużych bankach z Unii Europejskiej. Z tych badań wynika, że banki duże, stosujące w mniejszym zakresie wygładzanie dochodów, cechuje silniejszy związek między stopą wzrostu kredytów oraz współczynnikiem kapitałowym w okresie dobrej koniunktury gospodarczej. Wygładzenie dochodów nie ma jednak istotnego wpływu na ten związek w okresie dekoniunktury w Unii Europejskiej. Natomiast banki duże, których rezerwy cechują się większą wrażliwością rezerw na cykl koniunkturalny (tj. których rezerwy są relatywnie bardziej procykliczne) cechuje istotny statystycznie związek między stopą wzrostu kredytów i współczynnikiem kapitałowym w okresie dobrych uwarunkowań makroekonomicznych.

Badania Olszak i in. (2017b) ${ }^{14}$ stanowią rozwinięcie koncepcji badań Olszak i in. (2015b), ponieważ posługują się unikalną bazą danych finansowych kwartalnych dotyczących wszystkich banków komercyjnych prowadzących działalność w Polsce w okresie 1999-2012. Z badań tych wynika, że nadmierne wygładzanie dochodów wiąże się ze wzrostem wrażliwości stopy wzrostu kredytów na współczynnik adekwatności kapitałowej w okre-

13 Więcej o zjawisku wygładzania dochodów pisze Olszak (2015) i Skała (2015).

14 Wyniki tych badań były prezentowane na międzynarodowych konferencjach naukowych w 2018 r., tj. podczas: Financial Engeneering and Banking Society 2018 Conference, Internatioanal Risk Management Conference 2018 oraz International Conference on Finance INFINITI 2018. 
sie dekoniunktury. Zjawisko to szczególnie istotnie oddziałuje na związek między aktywnością kredytową i współczynnikiem adekwatności kapitałowej w przypadku banków, które są słabo dokapitalizowane. Badania te pokazują również, że banki o niższym stopniu procykliczności rezerw cechuje brak wrażliwości stopy wzrostu kredytów na współczynnik adekwatności kapitałowej w okresie dekoniunktury. To ograniczenie wpływu dotyczy szczególnie banków dobrze dokapitalizowanych.

\section{Wnioski}

Przeprowadzona w opracowaniu analiza prowadzi do następujących wniosków. Po pierwsze, na przestrzeni trzydziestu lat stosowania standardów adekwatności kapitałowej, występują istotne różnice w stosowanej w nich siatce pojęciowej w odniesieniu do strat ponoszonych przez banki na ekspozycjach kredytowych i w standardach rachunkowości. Przede wszystkim zauważyć należy, że standardom rachunkowości obce są pojęcia „rezerw specyficznych” i „rezerw ogólnych”.

Po drugie, wprowadzony współcześnie standard IFRS 9, określający zasady tworzenia oczekiwanej straty kredytowej, znacząco odmiennie definiuje podstawowe parametry ryzyka kredytowego, tj. PD, LGD i EAD, niz np. Bazylea III. Zatem nie ma spójności między IFRS9 i Bazyleą III w zakresie szacowania oczekiwanej straty.

Po trzecie, banki stosują zróżnicowane podejście do tworzenia rezerw na ryzyko (i straty) kredytowe. To zróżnicowanie podejścia ma istotny statystycznie i ekonomicznie wpływ na związek między stopą wzrostu kredytów i współczynnikiem kapitałowym banku.

\section{Literatura}

Basel Committee on Banking Supervision. (1988). International convergence of capital measurement and capital standards, July. Pozyskano z: www.bis.org/publ/bcbsc111.pdf, known as Basel I.

Basel Committee on Banking Supervision. (2006). International Convergence of Capital Measurement and Capital Standards: A Revised Framework (comprehensive version), June. Pozyskano z: www. bis.org/publ/bcbs128.htm, known as Basel II.

Basel Committee on Banking Supervision. (2011). Basel III: A global regulatory framework for more resilient banks and banking systems, June. Pozyskano z: www.bis.org/publ/bcbs189.pdf.

Basel Committee on Banking Supervision. (2017). Regulatory treatment of accounting provisionsinterim approach and transitional arrangements, March. 
European Banking Authority. (2016). Report on results from the EBA impact assessment of IFRS, 9, 10 November.

Górski, M. (2013). Rynkowy system finansowy. Warszawa: PWE.

Olszak, M. (2009a). Normy adekwatności kapitatowej. Warszawa: Wydawnictwo Naukowe Wydziału Zarządzania UW.

Olszak, M. (2009b). Dyscyplina rynkowa w bankowości z uwzględnieniem III Filara Nowej Umowy Kapitałowej. W: W. Szczęsny, J. Turyna (red.), Finansowe uwarunkowania rozwoju organizacji gospodarczych. Warszawa: Wydawnictwo Naukowe Wydziału Zarządzania UW.

Olszak, M. (2011). Bankowe normy ostrożnościowe. Białystok: Wydawnictwo Temida 2.

Olszak, M. i Olszak, M. (2014). Bazylea III - nowe standardy adekwatności kapitałowej i płynności. Przeglad Ustawodarestwa Gospodarczego. Pozyskano z: http://www.pug.pl/archiwum/ przeglad_ustawodawstwa,p1151403411?drukuj=1.

Olszak, M. (2015). Procykliczność dziatalności bankowej. Warszawa: C.H. Beck. https://www.ksiegarnia.beck.pl/ekonomia-finanse/id13466,Procyklicznosc-dzialalnosci-bankowej.html.

Olszak, M., Pipień, M. i Roszkowska, S. (2015). Do loan loss provisions accounting and procyclicality matter for the effects of capital on loan growth of big banks in the EU?. Research papers of Wroctaw University of Economics, 397, 171-181. Pozyskano z: http://www.dbc.wroc.pl/dlibra/ docmetadata? $\mathrm{id}=30186 \&$ from $=$ publication .

Olszak, M., Kowalska, I. i Roszkowska, S. (2016). Do macroprudential policy instruments affect the link between lending and capital ratio? - cross-country evidence. Faculty of Management Working Paper Series, 2. Faculty of Management, University of Warsaw. Pozyskano z: http:// www.wz.uw.edu.pl/portaleFiles/5630-Faculty of M/WP/WPS22016_olszak_roszkowska_kowalska_(1).pdf.

Olszak, M., Pipień, M., Kowalska, I. i Roszkowska, S. (2017a). What drives heterogeneity of cyclicality of loan loss provisions in the EU? Journal of Financial Services Research, 51(1), 55-96. https://doi.org/10.1007/s10693-015-0238-6.

Olszak, M., Kowalska, I., Świtała, F. i Chodnicka-Jaworska, P. (2017). The effect of capital ratio on lending- Do loan-loss provisioning practices matter? UW Faculty of Management Working Paper Series, 2, December.

Olszak, M., Kowalska, I. i Roszkowska, S. (2018). Macroprudential policy instruments and procyclicality of loan-loss provisions - cross-country evidence. International Journal of Financial Institutions, Markets and Money, Elsevier, 54(C), 228-257. https://doi.org/10.1016/j.intfin.2018.01.001.

Skała, D. (2015). Saving on a Rainy Day? Income Smoothing and Procyclicality of Loan-Loss Provisions in Central European Banks. International Finance, 18(1), 25-46. 



\section{PATRYCJA CHODNICKA-JAWORSKA*, PIOTR JAWORSKI**, KATARZYNA NIEWINSSKA***}

\section{Wptyw credit ratingów krajów na zmienność kursów akcji banków europejskich}

Celem rozdzialu jest badanie wptywu zmian credit ratingów krajów na zmienność kursów akcji banków europejskich. Dokonano przegladu literaturowego, a na jego podstawie postawiono następująca bipotezę badawcza: zmiana credit ratingu krajów wptywa istotnie statystycznie na zmienność kursów akcji bankówe europejskich. Do badania reykorzystano dtugoterminowe credit ratingi publikowane przez SEP w latach 2004-2015. Do analizy zastosowano zmienność 90-dniowa. Jako zmienne zależne użyto zmiennych makroekonomicznych oraz finansowych banków. Dane pobrano z bazy danych Thomson Reuters Database, Bloomberg oraz bazy Banku Światowego.

Słowa kluczowe: credit rating, zmienność, kursy akcji.

\section{THE IMPACT OF SOVEREIGN CREDIT RATINGS ON VOLATILITY OF BANKS' STOCK PRICES}

The purpose of the paper is to study the impact of changes in sovereign credit ratings on the volatility of share prices of European banks. A literature reviewe was conducted, and the following hypothesis was put forward: a change in sovereign credit ratings has a statistically significant impact on the volatility of share prices of European banks. Long-term issuer credit ratings published by SEP in the years 2004-2015 were used. The 90-day variation was used. Macroeconomic and financial variables of banks were used as dependent variables. Data was collected from the Thomson Reuters database, Bloomberg database and the World Bank database.

Keywords: credit rating, volatility, stock prices.

JEL: C23, G21, G24

* Dr Patrycja Chodnicka-Jaworska - Wydział Zarządzania Uniwersytetu Warszawskiego.

* Dr Piotr Jaworski - Wydział Zarządzania Uniwersytetu Warszawskiego.

**: Dr Katarzyna Niewińska - Wydział Zarządzania Uniwersytetu Warszawskiego. 


\section{Wprowadzenie}

Estymacja zmienności stóp zwrotu z cen akcji na podstawie danych historycznych może posłużyć jako miara ryzyka co do przyszłej wartości stopy zwrotu z danej akcji (Hull, 1998). Dokonując przeglądu literatury światowej na temat zmienności kursów akcji, można odnaleźć wiele badań dotyczących przede wszystkim predykcji jej przyszłej wartści. Mało publikacji naukowych koncetruje się na określeniu wpłwu determinat zmienności kursów akcji. Duża część ekonimstów podjęła próbę określenia czynników wpływających tylko na stopy zwrotu z cen akcji. Dowiedziono w nich przede wszystkim, że wpływają na nie determinanty makroekonomiczne i rynkowe (m.in. Chen Roll, 1986, s. 383-403; Kaul, 1987, s. 253-276; Mauro, 2000; Geetha, Mohidin, Chandran i Chong, 2001), a także w niektórych przypadkach wewnętrzne parametry spółki giełdowej (m.in. Banz, 1981, s. 3-18; Basu, 1983, s. 129-156; Bahandari, 1988, s. 444-455; Campbell, 1991, s. 157-179; Fama i French, 1992; Cooper, Jackson i Gary, 2003, s. 817-885; Beccalli, Casu i Girardone, 2006, s. 245-262; Castrén, Fitzpatrick i Sydow, 2006). Rezulaty tych badań wskazują, że tylko niektóre czynniki wpływają istotnie statystycznie, lecz często dopasowanie tych modeli jest bardzo niskie (Chodnicka-Jaworska i Niewińska, 2016, s. 39-47). Stąd wydało się zasadne postawienia pytania, jaki wpływ mają oceny ratingowe agencji S\&P oraz wybranych czynników zewnętrznych na 90-dniową zmienność historyczną z kursów akcji banków w Europie. Credit rating kraju jest to prospektywna opinia na temat wiarygodności kredytowej kraju w odniesieniu do konkretnego zobowiązania finansowego, szczególnej kategorii zobowiązań finansowych lub określonego programu finansowego (w tym ratingów średnioterminowych programów papierowych). W badaniu jako cedit rating kraju rozumie się, credit rating nadany instrumentom dłużnym (obligacjom) dotyczący zobowiązań wyrażonych w walucie obcej. Opinia odzwierciedla pogląd S\&P Global Ratings na temat zdolności dłużnika i gotowości do wywiązywania się z zaciągniętych zobowiązań finansowych w terminie wymagalności, a niniejsza opinia może oceniać warunki, takie jak zabezpieczenie i podporządkowanie zabezpieczeń, które mogą wpłynąć na ostateczną płatność w przypadku niewykonania zobowiązania.

Poszerzenie obecnej wiedzy odnośnie do wpływu oceny ratingowej danego kraju oraz zmiennych makroekonomicznych na zmienności dla rynku akcji banków ma znaczenie przede wszystkim w kontekście inwestycji portfelowych. Autorzy skoncetrowali się na sektorze bankowym, ponieważ powyższe badanie ma sens tylko dla dóbr o wysokiej płynności i jednorodności. Wydaje się, że akcje dla tego sektora są najlepsze do tego typu analizy ze względu 
na wysoką płynność (są to instytucje o wysokim kapitale) i wysoki poziom transparentności (ze względu np. na wymagania nadzoru). Aktywa składające się $\mathrm{z}$ akcji instytucji finansowych są jedną z najważniejszych pozycji portfeli inwestycyjnych, stąd określenie parametru zmienności wydaje się mieć bardzo wysoką wartość dla prawidłowej oceny inwestycji.

Powyższy rozdział składa się z czterech części. W pierwszej przedstawiono przegląd literatury z zakresu zmienności kursów akcji ze wskazaniem luki w dotychczasowym dorobku. W następnej części tej analizy opisano badania baz danych oraz użytą metodę badawczą. W części trzeciej zaprezentowano uzyskane wyniki wraz $\mathrm{z}$ ich interpretacją $\mathrm{w}$ świetle przyjętych założeń. W ostatniej części zawarto główne wnioski płynące $\mathrm{z}$ analizy.

\section{Przegląd literatury}

Dokonując przeglądu literatury dotyczącej zmienności historycznej kursów akcji, można zauważyć, że istnieje bardzo duża koncentracja przeprowadzonych badań w tym zakresie i dotyczą one jej predykcji na podstawie przede wszystkim historycznych wartości zmienności. Jest bardzo mało badań, które starają się określić i opisać mechanizm jej kształtowania. Obejmują te prace próbę identyfikacji determinant, ale liczba tego typu prac jest znacząco mniejsza niż prac dotyczących predykcji opartych przede wszystkim na modelach GARCH i ARCH (Pagan i Schwert, 1990, s. 267-290; Alberg Shalit i Yosef, 2008, s. 1201-1208).

W roku $1997 \mathrm{~K}$. Daly podjąt próbę określenia determinant zmienności stóp zwrotu z akcji na giełdzie w Australii. Analiza w jego pracy opierała się na danych indeksu Australian All Industrials Stock Market Index w przedziale czasowym pomiędzy lipcem 1972 a styczniem 1994 roku z częstotliwością miesięczną. W pracy został zastosowany uogólniony model najmniejszych kwadratów (Generalized Least Squares - GLS). Daly wykorzystał w tej analizie zmienne niezależne, takie jak: stopy zwrotu $\mathrm{z}$ wspomnianego wcześniej indeksu giełdowego, stopy procentowe (oprocentowanie 3-miesięcznych bonów bankowych w Australii), zmienność miesięcznego wskaźnika cen hurtowych, zmienność miesięcznej zmiany procentowej indeksu produkcji przemysłowej, zmienność podaży pieniądza, deficyt obrotów bieżących (zmienność deficytu na rachunku obrotów bieżących bilansu płatniczego w Australii) oraz zmienność waluty zagranicznej. Na podstawie uzyskanych wyników zostało wykazane, że jedynie zmienność na rynku walutowym nie wpływa istotnie statystycznie na badaną zmienność kursu głównego indeksu 
na ausytralijskiej giełdzie. Następne szerokie badanie dotyczące czynników zmienności przeprowadził Antonio Mele (2007). Do analizy wykorzytsał dłuższy szereg czasowy, ponieważ zawierał on aż 660 miesięcznych obserwacji (styczeń 1948-grudzień 2002). Podstawowym celem tego badania było wyodrębnienie wpływu determinant cyklu koniunkturalnego na zmienność stóp zwrotu z cen akcji. Uzyskanne wynniki wskazuja, że czynnikami wpływającymi na zmienność kursu akcji są: wskaźnik ceny akcji do dywidendy, miesięczne zmiany wskaźnika ceny akcji do dywidendy, stale zmniejszające się realne stopy zwrotu, deflacja nominalnych odpowiedników CPI, miesięczna rentowność bonów skarbowych, przyrost zmienności stóp zwrotu. W roku 2013 Mele wraz z Corradi i Distaso rozwineli jego wcześniejsze badanie i podjeli próbę określenia, jaki wpływ mają dane makroekonomiczne i zmienne nieobserwowalne na zmienność kursów akcji. Użyto modelu statystycznego no-arbitrage model, a zmienną objaśnianą był miesięczny poziom VIX, czyli zmienność implikowana indeksu S\&P500. Przyjęto szereg czasowy pomiędzy styczniem 1990 a grudniem 2006 roku (204 obserwacji w czasie). Zmienne niezależne, które oddziaływały na zmienność to: zmiana indeksu CPI i zmiana indeksu produkcji przemysłowej (672 obserwacje). Wyniki badań mówią, że wzrost produkcji przemysłowej odgrywa bardzo ważną rolę. Stały poziom produkcji przemysłowej prowadzi w dłuższym okresie do redukcji średniego poziomu zmienności o $10 \%$. A także udowodniono, że ok. $1 / 3$ poziomu zmienności można wytłumaczyć wskaźnikami makroekonomicznymi. Engle, Ghysels i Sohn (2008) zbadali również wpływ inflacji i wzrostu produkcji przemysłowej na codzienne zmienności rentowności akcji. Potwierdzili oni także, że zmienne makroekonomiczne (w postaci inflacji i wzrostu produkcji przemysłowej) wpływają istotnie statystycznie na zmienność stóp zwrotu z akcji. W 2012 roku została opublikowana praca Christiansena, Schmelinga i Schrimpfa, oparta na badaniach dotyczących determinant zmienności makroekonomicznych i finansowych. W publikacji tej badacze przede wszystkim koncentrują się na analizie zmienności stóp zwrotu z kursów akcji. W modelu zawarto aż 38 czynników makroekonomicznych i finansowych. Zespół ten podkreślał w swojej pracy, że zrozumienie ruchów zmienności jest bardzo ważne, ponieważ może być konsekwencją wejścia w inwestycję i decyzji o alokacji aktywów przez inwestorów na rynku. Głębsze zrozumienie wpływu makroekonomicznych wahań na zmienność na rynku akcji jest interesujące samo w sobie, ponieważ pomaga odkryć powiązania między zmianami cen akcji a czynnikami ryzyka, a także zmiennymi cyklicznymi. Wykazali również, że wiedza ta jest pomocna do przewidywania przyszłych dochodów na giełdzie. 
Przeprowadzona analiza literatury przedmiotu wskazuje na lukę badawczą na temat determinant zmienności, a także wykazuje, że większość analiz dotyczących determinat zmienności opiera się na zmiennych niezależnych opisywanych przez indeksy giełdowe (m.in.: Grossman i Shiller, 1981 s. 222-227; Daly, 1997; Mele, Corradi i Distaso, 2012). Dlatego w pracy tej poddana zostanie analizie 90-dniowa zmienność kursu akcji dla banków w Europie, których średnia kapitalizacja giełdowa w badanym okresie jest powyżej $100 \mathrm{mln}$ euro.

Istnieje luka badawcza na temat wpływu credit ratingów na zmienność cen akcji. Avramov, Chordia, Jostova i Philipov (2009), analizując wpływ kursów akcji na zmiany credit ratingów S\&P w latach 1985-2003, dowiedli że, inwestorzy oczekują premii za wyższe ryzyko. Jednocześnie wskazali istotny wpływ tylko w przypadku spadku ratingów. Prowadzone przez nich badania wskazują, że przeciętne stopy zwrotu nie różną się w grupach ryzyka w okresie stabilizacji lub poprawy uwarunkowań kredytowych, w $90 \%$ próbie obserwacji. Li, Jeon, Cho i Chiang (2008), wykonując badanie na kursach akcji podmiotów z 5 krajów azjatyckich w latach 1990-2003, dowiedli występowania efektu zakażania między krajami w związku ze zmianą credit ratingów, w szczególności w okresie kryzysu. Arezki i in. (2011) z kolei, wykonując analizy na krajach europejskich i zmianach ratingów i kursów akcji i CDS spreadów w latach 2007-2010, dowiedli występowania efektu zakażania CDS spreadów i rynku akcji. Dostrzegli jednocześnie wpływ obniżki ratingów na efekt zakażania między krajami.

W związku z tym celem rozdziału stało się zbadanie wpływu zmian credit ratingów krajów na zmienność kursów akcji banków europejskich. Postawiono następującą hipotezę badawczą: zmiana credit ratingu krajów wpływa istotnie statystycznie na zmienność kursów akcji banków europejskich.

\section{Opis danych i metody badawczej}

Badanie zostało przeprowadzone dla europejskich banków europejskich notowanych na giełdach papierów wartościowych, których średnia kapitalizacja wynosiła powyżej $100 \mathrm{mln}$ euro. Do badania wykorzystano długoterminowe credit ratingi emitenta dotyczące zobowiązań wyrażonych w walucie zagranicznej nadawane przez S\&P krajom europejskim ${ }^{1}$. Dane

1 Austria, Belgia, Chorwacja, Cypr, Dania, Finlandia, Francja, Grecja, Hiszpania, Holandia, Irlandia, Malta, Niemcy, Norwegia, Polska, Portugalia, Rosja, Rumunia, Serbia, Słowacja, Szwajcaria, Szwecja, Turcja, Węgry, Wielka Brytania, Włochy. 
dla lat 2004-2015 w ujęciu kwartalnym zebrano z bazy Thomson Reuters. Do analizy zastosowano liniową metodę dekompozycji zaproponowaną przez Ferri, Liu i Stiglitza (1999). Wyniki dekompozycji zaprezentowano w tabeli 1.

Tabela 1. Dekompozycja liniowa dla długoterminowych credit ratingów emitenta dotyczących zobowiązań wyrażonych $\mathrm{w}$ walucie obcej

\begin{tabular}{|l|c||l|l||l|c|}
\hline Rating & Kod & Rating & Kod & Rating & Kod \\
\hline AAA & 100 & BBB + & 65 & CCC + & 20 \\
\hline AA + & 95 & BBB & 60 & CCC & 15 \\
\hline AA & 90 & BBB- & 55 & CCC- & 10 \\
\hline AA- & 85 & BB+ & 50 & CC & 5 \\
\hline A+ & 80 & BB & 45 & NR & 0 \\
\hline A & 75 & BB- & 40 & SD, D & -5 \\
\hline A- & 70 & B + & 35 & NULL & 0 \\
\hline & & B & 30 & & \\
\hline & & B- & 25 & & \\
\hline
\end{tabular}

Źródło: opracowanie własne.

Weryfikacja hipotezy badawczej została przeprowadzona przy wykorzystaniu modeli panelowych. Model został zaprezentowany poniższym wzorem:

$$
Y_{i t}^{*}=\beta F_{i t}^{\prime}+\gamma Z_{i t}+\delta(F * Z)_{i t}=\varepsilon_{i t},
$$

gdzie:

$Y_{i t}^{*}$ - zmienna zależna mierząca 90-dniową zmienność kursów akcji banków europejskich;

$F_{i t}^{\prime}$ - wektor zmiennych niezależnych, gdzie:

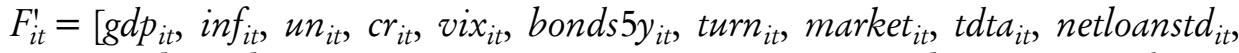
operlvg $_{i t}$, lvgratio $_{i t}$, tier $_{i t}$, iiti $_{i t}$, noniiti $i_{i t}$, totaicapital $i t, p e_{i t}$, eps $i t, b v p s_{i t}$, roa $_{i t}$, roe $_{i t}$, ptbv $_{i t}$, netloansta $i$, short $_{i t}$, long $\left._{i t}\right]$

gdzie:

$g d p_{i t}$ - stopa wzrostu PKB; inf $f_{i t}$ - stopa inflacji; $u n_{i t}$ - stopa bezrobocia; $c r_{i t}$ - długoterminowy credit rating kraju nadawany przez S\&P zobowiązaniom wyrażonym w walucie zagranicznej; vix $x_{i t}$ - indeks VIX; bonds $5 y_{i t}$ - oprocentowanie 5-letnich obligacji skarbowych; $t_{u r n}$ - zmiana wielkości obro- 
tu na rynku akcji; market $_{i t}$ - zmiana kapitalizacji rynkowej giełdy; $t_{t} t a_{i t}$ to netloanstd $_{i t}$ - kredyty netto do depozytów; operlvg $g_{i t}$ - dźwignia operacyjna; lvgratio $_{i t}$ - dźwignia finansowa; tier $_{i t}$ to Tier 1 ; iiti $_{i t}$ - dochody odsetkowe do dochody ogólem; noniiti $i_{i t}$ - dochody nieodsetkowe do dochody ogółem; totaicapital $_{i t}$ - kapitały własne do aktywów; $p e_{i t}$ - cena do zysku; eps $s_{i t}$ zysk na akcję; brps $i_{i t}$ - wartość księgowa na akcję; roa ${ }_{i t}$ - stopa zwrotu z aktywów; roe $e_{i t}$ - stopa zwrotu z kapitałów własnych; $p t b v_{i t}$ - cena do wartości księgowej; netloansta ${ }_{i t}$ - kredyty netto do aktywów ogółem; short ${ }_{i t}$ - inwestycje krótkoterminowe do aktywów ogółem; long ${ }_{i t}$ - inwestycje długoterminowe do aktywów ogółem;

$Z_{i t}$ - regresory niezmienne czasowe, które są ogólnie zmiennymi losowymi; $\varepsilon_{i t}-$ błąd losowy.

\section{Wyniki}

Przeprowadzona analiza dotyczy dwóch grup czynników: makroekonomicznych oraz finansowych. Spośród pierwszej grupy czynników należy wyróżnić stopę wzrostu PKB, stopę inflacji, stopę bezrobocia oraz credit rating. Okazuje się, że wraz ze wzrostem stopy wzrostu PKB rośnie zmienność kursów akcji. Jednocześnie inflacja nie należy do istotnych czynników makroekonomicznych w badanym modelu ekonometrycznym. Wzrost stopy bezrobocia powoduje silny wysoki wzrost zmienności. Świadczy to o pogarszającej się kondycji gospodarki, a to powinno wywołać spadek cen akcji na rynku giełdowym, ponieważ inwestorzy, pod wpływem pojawiania się gorszych informacji na rynku, mogą zrezygnować z inwestycji na rynku akcji na rzecz bardziej płynnych aktywów.

Silny istotny statystycznie wpływ obserwowany jest również w przypadku zmian credit ratingów krajów. Zmiana credit ratingów przyciąga lub odpycha inwestorów. Silniejszy wpływ zgodnie z dotychczasowymi badaniami obserwowany jest w przypadku obniżenia credit ratingu. Inwestorzy w obawie przed utratą zainwestowanego kapitału wycofują go. Poniższe badania to potwierdzają, ponieważ podwyższenie ratingu wywołuje spadek zmienności, co oznacza, że stabilizuje się cena akcji.

Spośród zmiennych rynkowych zaobserwowano nieistotny wpływ indeksu VIX oraz zmiennej opisujące zmianę kapitalizacji rynku kapitałowego w badanych krajach.

Istotnymi zmiennymi finansowymi są wskaźniki, tj.: kredyty do depozytów, cena do zysku, zysk na jedną akcję, wartość księgowa na jedną akcję 
oraz inwestycje długoterminowe do aktywów ogółem. Wskaźnik kredytów do depozytów oraz cena do zysku wpływają istotnie statystycznie na badaną zmienną zależną, ale zmiany wywołane wzrostem tych czynników są minimalne.

Kolejną zmienną finansową, która istotnie statystycznie wpływa na zmienność kursu akcji jest zysk na jedną akcję. Wzrost tego czynnika spowoduje spadek zmienności, a jego wzrost oznacza, że bank osiągnął wyższy zysk $\mathrm{i}$ jest go więcej do dystrybucji dla jego akcjonariuszy. Wzrost tej zmiennej powinien spowodować zatem wzrost ceny akcji, a co za tym idzie spowodować spadek zmienności. Ten sam kierunek oddziaływania ma zmienna wartość księgowa na jedną akcję. Wzrost wartości księgowej banku jest pozytywnie odbierany przez Inwestorów i zostało to również potwierdzone w przeprowadzonej analizie.

Wskaźnik inwestycji długoterminowych do aktywów ogółem mocno oraz istotnie statystycznie oddziałuje na badaną zmienną zależną. Jego zmiana o jeden punkt procentowy spowoduje spadek zmienności kursu akcji banku. Wzrost udziału inwestycji długoterminowych w bankach może świadczyć o stabilności instytucji finansowej. Nie jest zmienną posiadającą znaczący wpływ, co wynika ze specyfiki tego wskaźnika, stąd tak silne oddziaływanie, na badaną zmienność. Z punktu widzenia inwestorów wzrost inwestycji długoterminowych w udziale aktywów świadczy o wzroście wartości banku, co z kolei powinno wpłynąć na wzrost cen.

Tabela 2. Wyniki estymacji wpływu determinant na zmienność kursów akcji banków europejskich

\begin{tabular}{|l|r|c|c|c|c|c|c|c|}
\hline volatility90d & \multicolumn{1}{c|}{ Coef. } & P > z & \multicolumn{1}{c|}{ Coef. } & P > z & Coef. & P > z & Coef. & $P>z$ \\
\hline gdp & 0,5573 & 0,03 & 0,3573 & 0,07 & 0,3558 & 0,01 & & \\
\hline inf & $-1,1574$ & 0,27 & $-0,0754$ & 0,93 & $-1,8511$ & 0,01 & & \\
\hline un & 4,4457 & 0,00 & 3,3697 & 0,01 & 4,9748 & 0,00 & & \\
\hline cr & $-0,6337$ & 0,04 & $-0,4795$ & 0,04 & $-0,1433$ & 0,05 & $-0,9633$ & 0,03 \\
\hline vix & $-0,0047$ & 0,94 & 0,0618 & 0,17 & 0,0222 & 0,58 & & \\
\hline bonds5y & $-1,2858$ & 0,05 & $-0,3113$ & 0,66 & $-1,5253$ & 0,00 & & \\
\hline turn & 0,0732 & 0,78 & $-0,3186$ & 0,22 & $-0,3385$ & 0,01 & & \\
\hline market & 5,7144 & 0,32 & 2,6288 & 0,63 & 0,8361 & 0,72 & & \\
\hline tdta & 0,4938 & 0,94 & $-4,2300$ & 0,21 & & & & \\
\hline netloanstd & 0,0014 & 0,00 & 0,0012 & 0,00 & & & & \\
\hline
\end{tabular}




\begin{tabular}{|l|r|r|r|l|l|l|l|l|}
\hline volatility90d & \multicolumn{1}{c|}{ Coef. } & $\mathrm{P}>\mathrm{z}$ & \multicolumn{1}{c|}{ Coef. } & $\mathrm{P}>\mathrm{z}$ & Coef. & $\mathrm{P}>\mathrm{z}$ & Coef. & $\mathrm{P}>\mathrm{z}$ \\
\hline tier1 & $-0,0162$ & 0,99 & & & & & & \\
\hline totalcapital & 0,8925 & 0,42 & 0,8663 & 0,11 & & & & \\
\hline pe & 0,0049 & 0,06 & 0,0046 & 0,02 & & & & \\
\hline eps & $-1,5040$ & 0,00 & $-1,1916$ & 0,07 & & & & \\
\hline bvps & $-0,2496$ & 0,03 & $-0,1983$ & 0,03 & & & & \\
\hline roa & 6,6536 & 0,06 & 4,4997 & 0,37 & & & & \\
\hline roe & 0,0745 & 0,55 & 0,0374 & 0,75 & & & & \\
\hline ptbv & $-12,9745$ & 0,00 & $-6,0663$ & 0,07 & & & & \\
\hline operlvg & $-0,0027$ & 0,57 & $-0,0024$ & 0,58 & & & & \\
\hline lvgratio & $-0,0039$ & 0,59 & $-0,0047$ & 0,36 & & & & \\
\hline iiti & 0,0616 & 0,01 & 0,0602 & 0,01 & & & & \\
\hline noniiti & $-0,0781$ & 0,21 & $-0,1066$ & 0,25 & & & & \\
\hline netloansta & $-33,9842$ & 0,20 & $-23,2912$ & 0,09 & & & & \\
\hline shortterminvta & $-14,0236$ & 0,40 & 1,3601 & 0,93 & & & & \\
\hline longterminvta & $-897,0669$ & 0,00 & $-164,4077$ & 0,02 & & & & \\
\hline cons & 30,5315 & 0,00 & 30,8738 & 0,00 & 31,2701 & 0,00 & 34,0610 & 0,00 \\
\hline & & & & & & & & \\
\hline no obs & 738 & & 935 & & 4359 & & 7302 & \\
\hline no group & 45 & & 49 & & 140 & & 177 & \\
\hline Wald & 0,0000 & & 0,0000 & & 0,0000 & & 0,0322 & \\
\hline
\end{tabular}

Źródło: opracowanie własne.

\section{Podsumowanie}

Konkludując powyższą analizę zmienności kursów akcji sektora bankowego w Europie, dowiedziono, że niektóre czynniki makroekonomiczne oraz finansowe wpływają istotnie statystycznie na badaną zmienną zależną, tj.: zmiana PKB, stopa bezrobocia, kredyty do depozytów, cena do zysku, zysk na jedną akcję, wartość księgową na jedną akcję oraz inwestycje długoterminowe do aktywów ogółem. Przeprowadzone badanie dowiodło również, że jedną z istotnych zmiennych statystycznie, oprócz zmiennych makroekonomicznych oraz finansowych, jest także credit rating kraju. 
Istnieje ograniczona liczba badań na temat determinant zmienności kursów akcji banków, ale na podstawie wcześniejszych analiz możemy zauważyć, że wyniki uzyskane z przeprowadzonego badania podważają wcześniejsze badania dotyczące wpływu stopy inflacji na zmienności historyczne prowadzone przez Hestona (1993) oraz Engle’a, Ghyselsa i Sohna (2008). Wskaźnik ten w powyższej analizie nie oddziałuje istotnie statystycznie na badane zmienności kursów akcji banków w Europie.

Powyższe badanie rozszerza dotychczasową literaturę, ponieważ badania odnośnie do czynników wpływających na zmienność dotyczyły przede wszystkim indeksów giełdowych. Dokładnie analizują konkretne zmienności historyczne kursów akcji banków w Europie, a nie zastępują jednym ogólnym indeksem.

Postawiona hipoteza badawcza na temat istotnego statystycznie wpływu credit ratingu kraju na zmienność kursów akcji banków została zweryfikowana w sposób pozytywny. Wykazano, że wzrost credit ratingu powoduje wzrost stabilności kursów akcji banków. Jest to zgodne z dotychczasowymi badaniami na temat pozytywnego wpływu podwyżki credit ratingu na ceny akcji. Duże zmiany są efektem spadku not ratingowych. Jednocześnie istotny statystycznie wpływ credit ratingu kraju na badaną zmienność sugeruje występowanie wpływu zmian uwarunkowań makroekonomicznych na kursy akcji banków. Istotnym jednocześnie powstaje pytanie na temat siły wpływu credit ratingu na zmienność kursów akcji podmiotów z innych sektorów gospodarki. Czy istnieje silniejsze oddziaływanie na badaną zmienność $\mathrm{w}$ przypadku podmiotów z sektora pozafinansowego? Postawione pytanie badawcze będzie poddawane analizie w kolejnych pracach Autorów.

\section{Literatura}

Alberg, D., Shalit, H. i Yosef, R. (2008). Estimating stock market volatility using asymmetric GARCH models. Applied Financial Economics, 18(15), 1201-1208.

Arezki, R., Candelon, B. i Sy, A. (2011). Sovereign rating news and financial markets spillovers: Evidence from the European debt crisis. IMF Working Paper, 11(68).

Avramov, A., Chordia, T., Jostova, G. i Philipov, A. (2009). Credit ratings and the cross-section of stock returns. Journal of Financial Markets, 12(3), 469-499.

Bahandari, L.C. (1988). Debt/Equity ratio and expected common stock returns. Journal of Business, $45,444-455$.

Banz, R.W. (1981). The relationship between return and market value of common stocks. Journal of Financial Economics, 9, 3-18.

Basu, S. (1983). The relationship between earning yield, market value, and return for NYSE common stocks: further evidence. Journal of Financial Economics, 12, 129-156. 
Beccalli, E., Casu, B. i Girardone, C. (2006). Efficiency and Stock Performance in European Banking. Journal of Business Finance E Accounting, 33(1-2), s. 245-262.

Castrén, O., Fitzpatrick, T. i Sydow, M. (2006). What Drives Eu Banks' Stock Returns? Bank-Level Evidence Using the Dynamic Dividend-Discount Model. Working Paper Series, 677, Europejski Bank Centralny.

Chen, N.F., Roll, R. i Ross, S. (1986). Economic Forces and the Stock Market. The Journal of Business, 59(3), 383-403.

Christiansen, C., Schmeling, M., Schrimpf, A.A (2012). Comprehensive Look at Financial Volatility Prediction by Economic Variables, Monetary and Economic Department. BIS Working Papers, 374.

Cooper, M.J., Jackson, W.E., Gary, P.A. (2003). Evidence of predictability in the cross-section of bank stock returns. Journal of Banking E Finance, 27, 817-885.

Corradi, V., Distaso, W. i Mele, A. (2012). Macroeconomic Determinants of Stock Market Volatility and Volatility Risk-Premiums. Swiss Finance Institute Research Paper, 12-18.

Corradi, V., Distaso, W. i Mele, A. (2013). Macroeconomic determinants of stock volatility and volatility premiums. Journal of Monetary Economics, 60(2), 203-220.

Dańska-Brosiak, B. (2011). Dynamiczne modele panelowe w badaniach ekonomicznych. Łódź: Wydawnictwo Uniwersytetu Łódzkiego.

Engle, R.F., Ghysels, E. i Sohn, B. (2008). On the Economic Sources of Stock Market Volatility. AFA New Orleans Meetings Paper. Pozyskano z: https://ssrn.com/abstract $=971310$.

Fama, E.F. i French, K.R. (1992). The Cross-Section of Expected Stock Returns. The Journal of Finance, $47(2)$.

Geetha, C., Mohidin, R., Chandran, V.V. i Chong, V. (2001). The Relationship between Inflation and Stock Market: Evidence from Malaysia, United States and China. International Journal of Economics and Management Sciences, 1(2).

Grossman, S.J. i Shiller, R.J. (1981). The Determinants of the Variability of Stock Market Prices. American Economic Review, 71(2), 222-227.

Heston, S.A. (1993). Closed-form solutions for options with stochastic volatility. Review of Financial Studies, 6, 327-343.

Hull, J.C. (2011). Zarzadzanie ryzkiem instytucji finansowych. Warszawa: Wydawnictwa Profesjonalne PWN.

Kupiec, P.H. i Sharpe, S.A. (1991). Animal Spirits, Margin Requirements, and Stock Price Volatility. Journal of Finance, 46(2), 717-731.

Li, H., Jeon, B.N., Cho, S.Y. i Chiang, T.C. (2008). The impact of sovereign rating changes and financial contagion on stock market returns: evidence from five Asian countries. Global Finance Journal, 19(1), 46-55.

Mauro, P. (2000). Stock Returns and Output Growth in Emerging and Advanced Economics. IMF Working Paper, WP/00/89.

Pagan, A.R. i Schwert, G.W. (1990). Alternative models for conditional stock volatility. Journal of Econometrics, 45(1-2), 267-290. 



\section{JAKUB GÓRKA*}

\section{Architektura $i$ pryncypia systemu finansowego. Rozważania w perspektywie szkoty finansowej Profesora Mariana Górskiego}

W rozdziale syntetycznie przedstawiono optyke $M$. Górskiego na system finansowy $i$ zaprezentowano filary koncepcyjne jego podejścia. Charakteryzuje on system finansowy przez pryzmat instrumentów finansowych, podmiotów systemu finansowego i rynków finansowych. W rozdziale zachowano te strukturę w opisie $i$ dyskusji. Zmieniaja się warunki otoczenia społeczno-gospodarczego, postępuje cyfryzacja, rośnie skala powiazań sieciowych $i$ wspótzależności między podmiotami, transfer kapitatu i pieniądza ulega przyspieszeniu, pojawiaja się innowacyjne ustugi finansowe. Instrumenty finansowe staja się coraz bardziej ztożone, a ich konstrukcja $i$ bybrydowa natura wptywaja na ryzyko finansowe zarówno specyficzne, jak $i$ systemowe. Na znaczeniu zyskuje branża FinTech. Wyksztatca się gospodarka wspótdzielenia. Pryncypia systemu finansowego pozostaja niezmienne, ale podlega on dynamicznej transformacji. Klasyczne ujęcie systemu finansowego przez $M$. Górskiego odgrywa ważne role - porzadkująca i objaśniająca. Można je rozwijać i tączyć w szerszej perspektywie badawczej.

Słowa kluczowe: system finansowy, pośrednik finansowy, instrument finansowy, rynek finansowy, kapitał, majątek, płynność, ryzyko, dochód, cyfryzacja, globalizacja, rynek dwustronny, otwarta bankowość, FinTech, gospodarka współdzielenia, technologia.

* Dr Jakub Górka - Wydział Zarządzania Uniwersytetu Warszawskiego. Orcid ID: 00000003-3467-9624.

Autor pragnie podziękować za opinie i wskazówki, które pomogły podnieść jakość i przejrzystość tekstu profesorom: Grzegorzowi Jędrzejczakowi, Krzysztofowi Kalickiemu, Stanisławowi Kasiewiczowi, Markowi Monkiewiczowi, Leszkowi Pawłowiczowi, Kazimierzowi Ryciowi, Janowi K. Solarzowi. Szczególne podziękowania autor kieruje do profesora Sebastiana Skuzy i doktora Radosława Winiarskiego, którzy wniknęli merytorycznie i językowo w każde zdanie. Jeżeli jakieś sugestie zmian nie zostały ujęte, to dlatego, że miałyby wpływ na koncept i kształt opracowania. Jednocześnie stanowią one inspirację do ewentualnych kolejnych tekstów naukowych. Za wszelkie błędy i nieścisłości w rozdziale pełną odpowiedzialność ponosi autor. 


\section{ARCHITECTURE AND PRINCIPLES OF THE FINANCIAL SYSTEM. THE PERSPECTIVE OF PROFESSOR MARIAN GÓRSKI'S FINANCIAL SCHOOL}

The article synthetically describes $M$. Górski's view of the financial system and presents the conceptual pillars of his approach. He characterizes the financial system through the prism of financial instruments, entities of the financial system and financial markets. The article follows this structure in description and discussion. Socio-economic conditions are changing, digitization is progressing, the scale of network connections and interdependencies between entities is increasing, capital and money transfer is accelerating, and innovative financial services are emerging. Financial instruments are becoming more and more complex and their structure and bybrid nature are affecting financial risk, both specific and systemic. The FinTech industry is gaining in importance. The sharing economy is developing. The principles of the financial system remain unchanged, but it is transforming dynamically. M. Górski's classic approach to the financial system plays an important categorizing and explanatory role, which can be developed and combined in a broader research perspective.

Keywords: financial system, financial intermediary, financial instrument, financial market, capital, assets, liquidity, risk, profit, digitisation, globalisation, two-sided market, open banking, FinTech, sharing economy, technology.

JEL: E02, E21, E22, E44, G20, G21, O31, O33, P10

\section{Wprowadzenie}

Celem rozdziału jest przedstawienie zagadnień pośrednictwa finansowego i charakterystyka systemu finansowego w ujęciu M. Górskiego, następnie prezentacja zmian, jakie zachodzą w pośrednictwie finansowym i globalnej gospodarce oraz finalnie odpowiedź na trzy pytania:

- jaka jest rola i znaczenie klasycznego ujęcia M. Górskiego,

- czy zmianie ulegają główne zasady systemu finansowego i czy on sam transformuje,

- jakie są dla systemu finansowego konsekwencje cyfryzacji, rozwoju technologii i Internetu, ewolucji potrzeb społecznych i gospodarczych, innowacji finansowych?

W rozdziale wykorzystano wiele źródeł, ale główne stanowi doskonalona i uaktualniania od 2009 r. książka Profesora Mariana Górskiego pt. Rynkorey system finansowy wydana $\mathrm{w}$ czterech nakładach przez Polskie Wydawnictwo Ekonomiczne (ostatnie wydanie z 2018 r.). Dyskusję jednak poprowadzo- 
no szeroko, odwołując się do licznych opracowań traktujących o systemie finansowym i wybranych rozdziałów niniejszej monografii.

W podrozdziale drugim przedstawiono system finansowy zgodnie $\mathrm{z} \mathrm{kla-}$ sycznym podejściem M. Górskiego. Wyjaśniono w nim mechanizm transferu kapitału od gospodarstw domowych przez pośredników finansowych działających na rynkach finansowych do przedsiębiorstw prywatnych i państwa. Określono funkcje systemu finansowego i jego podmiotów oraz objaśniono rolę i znaczenie instrumentów finansowych w procesie transformacji kapitału. Zwrócono też uwagę na kwestię efektywności transferu kapitału w systemie finansowym oraz cele i efektywność inwestycji publicznych i prywatnych.

W trzecim podrozdziale znalazł się skonsolidowany bilans (finansowy) gospodarki krajowej, zestawiony przez M. Górskiego. Wskazano w nim na otwarte pole badawcze w tym obszarze i podjęto się szerszej dyskusji, m.in. na temat relacji zobowiązań do majątku gospodarstw domowych i stopnia podatności wysoko rozwiniętych gospodarek na szoki makroekonomiczne wynikającej m.in. z zadłużenia sektora prywatnego (gospodarstw domowych i przedsiębiorstw). Za przykład posłużył kryzys finansowy roku 2008.

W czwartym podrozdziale zeprezentowano model finansowy pośrednika finansowego zaproponowany przez M. Górskiego i wykorzystujący nazewnictwo kapitałów adekwatne do ich charakteru. Wyłożono, jak działają pośrednicy finansowi i jak po ich bilansie można zidentyfikować funkcję pośrednika finansowego. Pośrednicy finansowi zostali usystematyzowani. Wyeksplikowano znaczenie i rodzaje ryzyka obecne w działalności pośredników finansowych oraz dokonano ponownej ich klasyfikacji z punktu widzenia transferu ryzyka kredytowego na inwestorów. W punkcie tym rozróżniono strumienie od zasobów gospodarczych, jednocześnie dowodząc, że te kategorie ekonomiczne są ze sobą powiązane i się przenikają.

W piątym podrozdziale skoncentrowano się na pieniądzu i niepieniężnych instrumentach finansowych, podając ich definicję i określając kryteria klasyfikacyjne przydatne w ocenie ich natury. Pokazano, że inżynieria finansowa, będąca przejawem innowacyjności i odpowiedzią na potrzeby praktyki gospodarczej, prowadzi do stworzenia coraz bardziej złożonych instrumentów finansowych (np. produkty strukturyzowane), lecz uruchomione przez nią procesy (np. sekurytyzacja) mogą mieć istotne implikacje w ryzyku specyficznym i systemowym. Uargumentowano, że podejście bilansowe niesie dużą wartość jako narzędzie pomocne w zrozumieniu działania instrumentów finansowych i nowych zjawisk. Przeanalizowano w ten sposób waluty alternatywne (altcoiny) na przykładzie bitcoinów. 
W szóstym - wgłębiono się w naturę instrumentu finansowego i papieru wartościowego. Opisano trzy najważniejsze cechy (triadę atrybutów) instrumentów finansowych - płynność, ryzyko, dochód. Wyjaśniono, jak się je mierzy i jaka jest między nimi zależność przyczynowo-skutkowa. Te parametry są obecne w modelach i wskaźnikach służących ocenie efektywności inwestycji.

W siódmym podrozdziale przedstawiono dwa podziały rynków finansowych. Odniesiono się do skutków bilansowych dla emitentów i inwestorów emisji i handlu instrumentami finansowymi na rynku pierwotnym i wtórnym. Wyeksponowano rolę międzybankowego rynku depozytów, na którym kształtuje się rynkowa cena pieniądza.

Ósmy podrozdział poszerza perspektywę oglądu systemu finansowego o zmiany wynikające z wirtualizacji i dematerializacji, rozwoju nowych technologii, branży FinTech, platform dwustronnych, gospodarki współdzielenia, nowych form finansowania, otwartej bankowości, finansowania algorytmicznego. Naświetlono w nim i przeanalizowano ratio istnienia pośredników finansowych. Osadza on też dyskusję w kontekście innowacyjności i konkurencji na rynku usług finansowych oraz wyzwań, jakie niesie rosnąca liczba regulacji sektora finansowego.

Podrozdział dziewiąty syntetyzuje klasyczne ujęcie systemu finansowego przez M. Górskiego i zestawia je z nową perspektywą, przeobrażeniami pośrednictwa finansowego i całej rzeczywistości społeczno-gospodarczej. Udzielono w nim odpowiedzi na trzecie pytanie badawcze ze wstępu, określając implikacje zmian systemu finansowego.

W ostatnim, dziesiątym - znalazło się podsumowanie i odpowiedź na dwa pierwsze pytania postawione we wstępie.

\section{System finansowy w ujęciu klasycznym M. Górskiego}

W systemie finansowym kapitał przekazywany jest od podmiotów, które mają jego nadmiar do podmiotów, które mają jego niedobór. Następuje transformacja oszczędności w inwestycje. Akumulowany kapitał w procesie transformacji strumienia oszczędności alokowany jest $\mathrm{w}$ inwestycjach produkcyjnych i konsumpcji publicznej. Wydatki prywatne i publiczne napędzają wzrost gospodarczy mierzony PKB lub dochodem narodowym. Na rysunku 1 zaprezentowano uproszczony schemat systemu finansowego gospodarki, którego nieco inną i bardziej rozbudowaną wersję przedstawia M. Górski (2018: rozdz. 4). 


\section{Rysunek 1. System finansowy gospodarki}

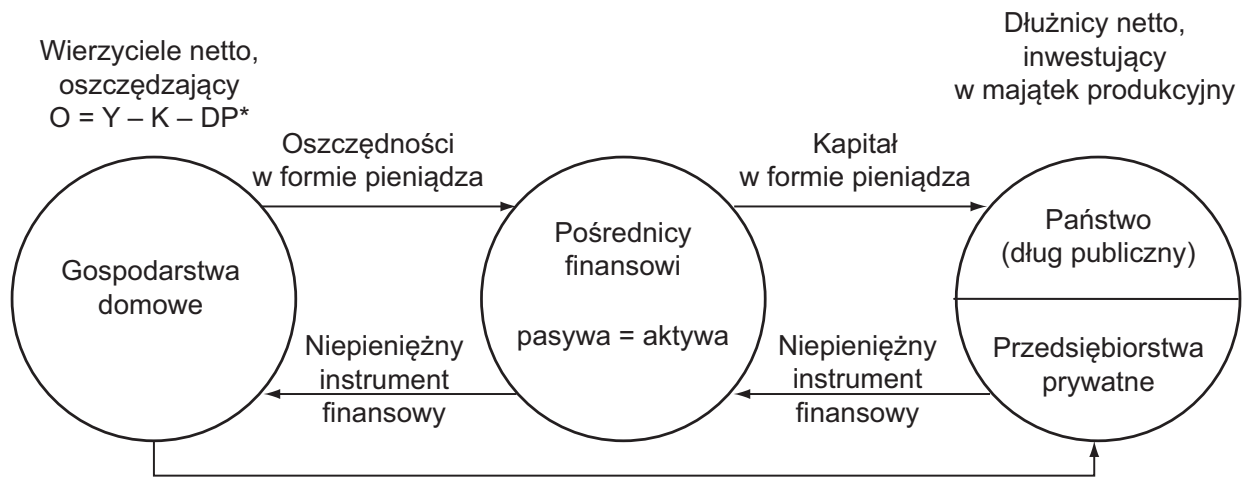

$\checkmark$ Transformacja płynności w dochody obciążone ryzykiem.

$\checkmark$ Akumulacja i alokacja kapitału.

$\checkmark$ Oszczędności gospodarstw domowych trafiają do podmiotów gwarantujących ich efektywne wykorzystanie w skali gospodarki krajowej.

Adnotacja: * O - oszczędności, Y - dochód rozporządzalny, K - wydatki konsumpcyjne, DP - daniny publiczne.

Źródło: opracowanie własne na podstawie: Górski, 2002/2018 oraz Górski, 2018.

Istotą systemu finansowego i siłą napędową wzrostu gospodarczego jest proces przekształcania oszczędności w inwestycje. W ujęciu brutto różne podmioty (gospodarstwa domowe, przedsiębiorstwa sfery realnej gospodarki, instytucje finansowe) inwestują nadwyżki kapitału w rozmaite instrumenty finansowe, $\mathrm{w}$ ten sposób uczestnicząc $\mathrm{w}$ procesie inwestycyjnym prywatnych podmiotów gospodarczych i państwa nieustannie poszukujących źródeł finansowania. W ujęciu netto proces wygląda tak, jak go zaprezentowano na rysunku 1. Gospodarstwa domowe jako finalni wierzyciele (wierzyciele netto) w gospodarce dysponują dochodem, który przeznaczają na wydatki konsumpcyjne (dobra i usługi zakupione na rynkach realnych) i płacą daniny publiczne (podatki, składki na ubezpieczenia społeczne i inne opłaty publiczne). Nadwyżka dochodu ponad konsumpcję i wydatki wynikające z zobowiązań publicznoprawnych stanowi oszczędności. Oszczędności gospodarstw domowych mogą być inwestowane bezpośrednio w inwestycje gospodarcze (indywidualna działalność gospodarcza), jednak zazwyczaj trafiają do sektora wyspecjalizowanych i profesjonalnych pośredników finansowych. Liczna (rodzajowo i liczbowo) grupa pośredników finansowych funkcjonujących na rynku finansowym (pieniężnym i kapitałowym) oferuje zróżnicowane (niepieniężne) instrumenty finansowe (np. depozyty, jednostki uczestnictwa, 
certyfikaty inwestycyjne, bony, obligacje, akcje). Instrumenty finansowe są prawem majątkowym, a jednocześnie (przyszłym) dochodem obciążonym ryzykiem. Instrumenty finansowe mają za zadanie przynieść określoną stopę zwrotu inwestorowi. Pośrednicy finansowi budują swoje kapitały (pasywa) z pozyskanych środków pieniężnych, które następnie inwestują (majątek, aktywa), dokonując transformacji oszczędności w inwestycje prywatnych podmiotów gospodarczych i podmiotów publicznych (szczebla centralnego i samorządowego), zgłaszających zapotrzebowanie na kapitał i gotowych za niego zapłacić. Kapitał w formie pieniądza (czystej płynności) przekazywany im jest przez pośredników finansowych w zamian za określony (niepieniężny) instrument finansowy będący zobowiązaniem (np. kredyt, pożyczka, bon, obligacja) lub udziałem (np. akcja, udział w sp. z o.o.). W ten sposób odbywa się efektywna akumulacja, transformacja i alokacja kapitału gospodarstw domowych w systemie finansowym gospodarki. Akumulacja kapitału jest procesem długotrwałym. Niosące zniszczenia wojny i niesprzyjający ustrój społeczno-gospodarczy (np. w Polskiej Rzeczpospolitej Ludowej system gospodarki centralnie planowanej i dominującej własności publicznej) wpływają na ten proces negatywnie (por. Jędrzejczak, 2018). Dlatego istnieje różnica $\mathrm{w}$ poziomie bogactwa między Polską a zachodnimi gospodarkami rynkowymi Europy i Stanów Zjednoczonych.

Tłumacząc zasadę działania systemu finansowego gospodarki, M. Górski (2018, s 76) w wersji rozbudowanej ujmuje też zagranicę. Otwartą gospodarkę krajową zasilają bowiem oszczędności podmiotów zagranicznych (finansowych i niefinansowych), podmioty krajowe inwestują zaś za granicą. Gospodarka krajowa absorbuje także środki pieniężne w ramach rachunku obrotów bieżących (transakcje towarowe, dochody z pracy i kapitału, transfery nieodpłatne, odsetki i dywidendy). Podmioty krajowe mogą mieć więcej lub mniej zagranicznych aktywów finansowych w relacji do wyemitowanych przez siebie pasywów finansowych w posiadaniu podmiotów zagranicznych. Kraj z utrzymującą się przewagą zagranicznych aktywów finansowych w rękach podmiotów krajowych ponad wyemitowane pasywa finansowe w rękach podmiotów zagranicznych staje się wierzycielem netto zagranicy, natomiast kraj w sytuacji odwrotnej - dłużnikiem netto zagranicy.

Państwo dokonuje redystrybucji dochodów publicznych. Przeznacza je na realizację celów gospodarczych (w tym infrastrukturalnych), administracyjnych i społecznych. Gdy dochody (wpływy) z danin publicznych nie wystarczają na pokrycie wydatków (inwestycyjnych i konsumpcji publicznej), sektory rządowy i samorządowy (gminy, powiaty, województwa) zaciągają dług publiczny (dług sektora finansów publicznych). Składają się na niego 
pożyczki, kredyty lub wyemitowane dłużne papiery wartościowe (obligacje skarbowe i samorządowe).

Ocena efektywności inwestycji publicznych i prywatnych sprowadza się do porównania kosztów i korzyści. Jednak inwestycje, zwłaszcza publiczne, nie zawsze mają na celu maksymalizację dochodu i stopy zwrotu, służąc m.in. celom społecznym, ekologicznym, prorozwojowym. Dlatego w ocenie efektywności inwestycji należy brać pod uwagę wiele kryteriów (Kasiewicz i Rogowski, 2009). Należy jednak pamiętać, że duża skala inwestycji publicznych powoduje opisany w podręcznikach makroekonomii efekt wypierania inwestycji prywatnych (Begg i in., 2014; Kamerschen i in., 1993, por. m.in. szkołę klasyczną i keynesowską ekonomii).

\section{Skonsolidowany bilans (finansowy) gospodarki krajowej}

M. Górski (2018, p. 10.4) zestawia skonsolidowany bilans (finansowy) gospodarki krajowej dla dziewięciu grup podmiotów reprezentujących:

- sektor realny:

o gospodarstwa domowe,

o przedsiębiorstwa,

o państwo (budżet i Skarb Państwa),

- sektor finansowy (bankowy i pozabankowy):

o bank centralny,

o banki depozytowo-kredytowe,

o instytucje pożyczkowe,

o ubezpieczyciele,

o fundusze powiernicze (emerytalne i inwestycyjne),

- otoczenie światowe (zagranica, wszystkie podmioty zbiorczo).

M. Górski ujmuje dwadzieścia instrumentów finansowych (od gotówki i depozytów, przez obligacje, bony, kredyty, pożyczki, akcje i udziały, do instrumentów emitowanych przez fundusze inwestycyjne, polis ubezpieczeniowych, walut, dewiz i zbiorczej klasy długoterminowych zagranicznych aktywów inwestycyjnych). Dla każdej grupy podmiotów określa czy dany instrument znajduje się $\mathrm{w}$ jej pasywach, czy w aktywach poprzez oznaczenie odpowiednio „” lub „+”. Niektóre instrumenty finansowe występują jako zarówno aktywo, jak i pasywo danej grupy podmiotów (np. pożyczki u gospodarstw domowych lub u przedsiębiorstw). Wtedy M. Górski określa czy dany instrument finansowy dominuje jako pasywo czy aktywo 
(np. pożyczki raczej dominują jako pasywo tak u gospodarstw domowych jako grupy, jak i u przedsiębiorstw jako grupy).

Wartościowo dla danego instrumentu finansowego suma znaków „+ ” i „-” wszystkich podmiotów łącznie się znosi, czyli wynosi O. Jednak z uwagi na pominięcie majątku rzeczowego, suma aktywów nie musi równać się sumie pasywów. Majątek rzeczowy pośredników finansowych jest niewielki. Dlatego dla tej grupy suma aktywów i pasywów finansowych jest mniej więcej taka sama. U pośrednika finansowego widać, jak kapitał pracuje, za pośrednictwem jego bilansu aktywa (głównie wierzytelności) jednych podmiotów (stanowiące pasywa finansowe pośrednika finansowego) są przekształcane w pasywa (głównie zobowiązania) innych podmiotów (stanowiące aktywa finansowe pośrednika finansowego) (zob. rys. 1). Przykładowo, w banku depozytowo-kredytowym depozyty będące wierzytelnościami klientów banku są transformowane w kredyty będące zobowiązaniem innych jego klientów. Przedsiębiorstwa prywatne i państwo są dłużnikami netto w gospodarce (aktywa finansowe < pasywa finansowe), gospodarstwa domowe sac zaś wierzycielami netto $\mathrm{w}$ gospodarce (aktywa finansowe $>$ zobowiązania finansowe).

W oparciu o teoretyczne ramy zakreślone przez M. Górskiego, dalszym krokiem badawczym mogłoby być rozwinięcie systemu rachunków narodowych i weryfikacja na rzeczywistych danych liczbowych, jak się prezentuje bilans (finansowy) gospodarki Polski lub innych krajów.

Warto też zwrócić uwagę na pewne istotne kwestie. Zgodnie z koncepcją monetarystów (por. np. Friedman, 1992) dobra ruchome (np. samochody) lub nieruchomości są istotnym składnikiem majątku i determinują m.in. popyt na pieniądz gospodarstw domowych, kierujących się tzw. stałym (permanentnym) dochodem. Ponadto, nieruchomość może być też traktowana jako aktywo finansowe (instrument finansowy). Ujmując w kalkulacji bilansu gospodarstw domowych majątek rzeczowy (którego część może zostać uznana za dobra inwestycyjne $\mathrm{i}$ instrumenty finansowe przynoszące określony dochód), może powstać jeszcze większa nadwyżka majątku ponad zobowiązaniami, potwierdzając pozycję gospodarstw domowych jako wierzycieli netto $\mathrm{w}$ gospodarce.

Jednakże należy pamiętać w kontekście zarządzania finansami osobistymi gospodarstw domowych, że w rozwiniętych kapitalistycznych gospodarkach rynkowych odchodzi się coraz bardziej od zasad austriackiej szkoły ekonomii (formułowanych m.in. przez Misesa i Hayeka; zob. Mises 2012; Hayek 2007) i żyje ponad stan na kredyt. Można to m.in. zaobserwować po relacji kredytu gospodarstw domowych do PKB (por. panelo- 
we zestawienie kredytu sektora prywatnego do PKB dla różnych krajów w: Żyżyński 2018).

Ponadto, rośnie relacja aktywów finansowych sektora finansowego do PKB. J.K. Solarz podaje, że jeżeli aktywa sektora finansowego przekraczają $100 \% \mathrm{PKB}$, to uznaje się go za nadmiernie rozbudowany. Rynki finansowe w nadmiernym stopniu służą wówczas celom spekulacji (i realizowaniu zysków nadzwyczajnych), nie zaś wspieraniu potrzeb realnej gospodarki, a to otwiera pole populizmu, nadużyć i wpływa na ryzyko systemowe (Solarz, 2014, s. 8). L. Pawłowicz przywołuje statystykę dla gospodarek Unii Europejskiej. W niektórych krajach UE występuje niespotykanie wysoka relacja sumy bilansowej banków do rocznego PKB - ok. 350\%. To zaś w połączeniu ze zjawiskiem pokusy nadużycia (moral hazard) w pośrednictwie finansowym sprawia, że istotnie rośnie ryzyko systemowe, a systemowe rozwiązania Unii Bankowej przyjęte w Unii Europejskiej mogą się okazać niewystarczające w jego ograniczeniu (Pawłowicz, 2018).

Rozrost aktywów finansowych jest cechą (dysfunkcją?) aktualnej kapitalistycznej formacji gospodarczej i reżimu monetarnego opartego na kreacji pieniądza bankowego w systemie rezerwy cząstkowej. Powstaje pytanie wagi systemowej, czy rzeczywiście gospodarstwa domowe w każdej gospodarce i w każdym czasie są wierzycielami netto w ujęciu wąskim, tj. porównując ich aktywa finansowe $\mathrm{z}$ zobowiązaniami finansowymi oraz $\mathrm{w}$ ujęciu szerokim, ujmując także ich cały majątek rzeczowy. Jest to potencjalnie ciekawe i warte eksploracji pole badawcze.

Stopień podatności wysoko rozwiniętych gospodarek na szoki makroekonomiczne wynika właśnie m.in. z rozmiaru zadłużenia gospodarstw domowych i przedsiębiorstw ( $\mathrm{z}$ rozmiaru zadłużenia państwa naturalnie też). W czasie dekoniunktury, kryzysu finansowego i gwałtownego spadku rynkowej wartości nieruchomości i cen aktywów finansowych, zobowiązania finansowe mogą zacząć przeważać nad majątkiem (jeśli nie całego sektora gospodarstw domowych, to znaczącej jego części). Dobrym przykładem jest kryzys finansowy roku 2008 zapoczątkowany upadkiem Lehman Brothers. W Stanach Zjednoczonych przed kryzysem nawet osoby o niskich, niepewnych dochodach i bez majątku (tzw. NINJA, no income, no jobs, no assets) dostawały kredyt hipoteczny na zakup nieruchomości, których ceny rosły na skutek wysokiego popytu. Położył temu kres kryzys 2008 r., który wywołał korekty cen aktywów, w tym raptowne spadki cen nieruchomości będących zabezpieczeniem kredytów. Wartość nieruchomości spadała poniżej wartości zobowiązania kredytowego wielu kredytobiorców. Miało to konsekwencje systemowe. $Z$ pewnością istotnie zwiększyła się w tym czasie wartość zobo- 
wiązań finansowych gospodarstw domowych w relacji do ich całego majątku (finansowego i rzeczowego).

Spadki rynkowej wartości rzeczowego i finansowego majątku mogą mieć też istotny wpływ nie tylko na bilanse gospodarstw domowych, ale także na sytuację finansową i bilanse sektora przedsiębiorstw produkcyjnych, nie wspominając o sytuacji samych instytucji finansowych.

\section{Model finansowy i ryzyko pośrednika finansowego}

Zadaniem pośrednika finansowego, wynikającym $\mathrm{z}$ istoty jego działania, jest transformacja kapitału, efektywny transfer kapitału od podmiotów $\mathrm{z}$ nadwyżką do podmiotów z niedoborem, zgłaszającym popyt na finansowanie. Optymalizujący zysk pośrednik finansowy będzie stosował maksymalny lewar finansowy (dźwignię finansową), tj. zwiększał udział tańszego od właścicielskiego kapitału dłużnego $\mathrm{i}$ inwestował go w majątek finansowy o potencjalnie najwyższej stopie zwrotu przy założonym poziomie ryzyka. Bilans pośrednika finansowego „pracuje”. Kapitał dłużny przekształcany jest efektywnie w majątek finansowy. Pośrednik finansowy powinien maksymalizować wielkość i udział majątku finansowego, a minimalizować majątku rzeczowego. Regulatorzy mogą zmniejszać wysokość dźwigni finansowej i tym samym wymagać wyższych funduszy własnych w obawie o materializację ryzyka systemowego wywołanego np. nadmiernym kredytowaniem podmiotów o niskiej zdolności kredytowej. Widoczne jest to w sektorze bankowym, w którym od lat w ślad za umowami bazylejskimi (Bazylea I, II, III) rosną wymogi kapitałowe (Kalicki, 2018; Olszak, 2018). Zobowiązuje się banki do utrzymywania dodatkowych buforów kapitałowych i wyższych współczynników wypłacalności. Intencją nadzorców jest doprowadzenie do wzrostu funduszy własnych, w tym głównie kapitałów właścicielskich banków, i redukcja dźwigni finansowej przez nie stosowanej. Nadzorcy dbają o adekwatność kapitałową banków w relacji do podejmowanego przez nie ryzyka.

Rysunek 2 przedstawia bilans pośrednika finansowego zaproponowany przez M. Górskiego. Nie używa on terminów „kapitał obcy” i „kapitał własny", tylko w ich miejsce wprowadza terminy bardziej precyzyjne i lepiej oddające istotę każdego z kapitałów: „kapitał dłużny” i „kapitał właścicielski”. Kapitał dłużny jest zwrotnym zobowiązaniem wobec wierzycieli podmiotu gospodarczego. Kapitał właścicielski nie jest kapitałem własnym podmiotu gospodarczego, lecz jego właścicieli (i nakłada określone obowiązki na pod- 
miot gospodarczy wobec jego właścicieli - prawa majątkowe i korporacyjne tych ostatnich).

Tradycyjnie, prezentację bilansu pośrednika finansowego powinno się zaczynać od źródeł jego finansowania, tj. pasywów (kapitałów), a następnie przedstawiać aktywa (majątek). W banku depozytowo-kredytowym kapitały właścicielskie stanowią kilkanaście procent, pozostała część to kapitały dłużne (głównie depozyty). Majątek banku depozytowo-kredytowego tworzą w przeważającej większości aktywa finansowe (głównie kredyty), a majątek rzeczowy stanowi tylko kilka procent aktywów banku. W zakładzie ubezpieczeń udział kapitału dłużnego i majątku finansowego w bilansie też jest bardzo wysoki, ale nieco niższy niż w komercyjnym banku depozytowokredytowym. W funduszu inwestycyjnym kapitały uczestników stanowią 100\% pasywów, podobnie jak 100\% aktywów stanowi majątek finansowy (aktywa finansowe $\mathrm{w}$ portfelu instrumentów finansowych zakupionym zgodnie z przyjętą strategią inwestycyjną przez zarządzającego funduszem za środki pieniężne inwestorów - uczestników funduszu powierniczego). W przedsiębiorstwie produkcyjnym udział kapitału dłużnego i majątku finansowego w bilansie jest zdecydowanie niższy niż u pośredników finansowych.

Rysunek 2. Bilans pośrednika finansowego

\begin{tabular}{c|c} 
Aktywa & Pasywa \\
\hline $\begin{array}{c}\text { Majątek finansowy } \\
\text { (wysoki udział w aktywach, } \\
\text { aktywa o różnym stopniu } \\
\text { płynności) }\end{array}$ & $\begin{array}{c}\text { Kapitał dłużny } \\
\text { (wysoki udział w pasywach, } \\
\text { pasywa o różnym terminie } \\
\text { wymagalności) }\end{array}$ \\
$\begin{array}{c}\text { Majątek rzeczowy } \\
\text { (niski udział w aktywach) }\end{array}$ & $\begin{array}{c}\text { Kapitał właścicielski } \\
\text { (niski udział w pasywach) }\end{array}$
\end{tabular}

Źródło: opracowanie własne na podstawie: Górski, 2018, s. 92.

Grupa pośredników finansowych jest liczna i bogata rodzajowo. Instytucje pośrednictwa finansowego można podzielić na dwie grupy:

1) depozytowo-kredytowe: bank centralny, komercyjne uniwersalne i specjalistyczne banki depozytowo-kredytowe, banki spółdzielcze i komunalne, kasy kredytowe (spółdzielcze kasy oszczędnościowo-kredytowe i pracownicze kasy zapomogowo-pożyczkowe), parabanki; 
2) niedepozytowe: giełdy finansowe wraz $\mathrm{z}$ domami i biurami maklerskimi, fundusze inwestycyjne (powiernicze), fundusze emerytalne, towarzystwa ubezpieczeń (na życie i majątkowe), towarzystwa zarządzania aktywami, banki inwestycyjne, fundusze inwestycyjne typu Venture Capital i Private Equity, instytucje faktoringowe, przedsiębiorstwa leasingowe.

Grupa niedepozytowych pośredników finansowych zyskuje na znaczeniu. Jest szeroka i zróżnicowana. J.K. Solarz (2014) kwalifikuje pośredników tej grupy (wraz z parabankami i działalnością banków depozytowo-kredytowych kreujących pieniądz w oderwaniu od potrzeb gospodarki realnej) do tzw. bankowości równoległej (shadow banking), a ich działalność rozpatruje jako systemową innowację finansową, która ma swoje blaski i cienie, a także wpływa wydatnie na wzrost ryzyka w systemie finansowym.

Działalności pośredników finansowych towarzyszy ryzyko. Najpoważniejszym rodzajem ryzyka jest ryzyko wypłacalności, które może zostać wywołane przez inne rodzaje ryzyka, głównie ryzyko płynności i ryzyko kredytowe. Pozostałymi rodzajami ryzyka występującymi w działalności pośredników finansowych są: rynkowe (kursu walutowego, stopy procentowej i rynkowych cen aktywów finansowych), operacyjne, prawne, utraty reputacji. Te rodzaje ryzyka korelują ze sobą i wpływają na siebie wzajemnie. Inwestor dostarczający kapitał pośrednikowi finansowemu ryzykuje jego utratę. Każdy rodzaj pośrednika finansowego ma swoją specyfikę wyrażająca się profilem ryzyka, tj. ekspozycją na różne rodzaje ryzyka oraz sposobem, w jaki pośrednik finansowy przenosi je na swoich wierzycieli i udziałowców powierzających mu swój kapitał. M. Górski systematyzuje pośredników finansowych wg tego, jak transferują oni swoje ryzyko kredytowe (ew. inne rodzaje ryzyka) na inwestorów (2018, s. 90):

1) trzy grupy nieprzenoszące własnego ryzyka kredytowego na inwestorów:

- banki depozytowo-kredytowe;

- instytucje ubezpieczeniowe;

- instytucje pożyczkowe (szeroka grupa zawierająca m.in. banki hipoteczne, firmy leasingowe, firmy faktoringowe, instytucje trudniące się udzielaniem pożyczek gotówkowych);

2) dwie grupy pośredników przenoszących własne ryzyko kredytowe na inwestorów:

- powiernicy ( $\mathrm{w}$ tym fundusze emerytalne $\mathrm{i}$ inwestycyjne);

- fundusze powiernicze wysokiego ryzyka Venture Capital $i$ Private Equity (VC/PE); 
3) grupę pośredników, którzy nie ponoszą ryzyka kredytowego, a czerpią dochody prowizyjne od swoich klientów:

- instytucje rynków finansowych wraz z niezbędną do ich działania infrastrukturą i otoczeniem (giełdy, maklerzy, brokerzy, doradcy inwestycyjni, agencje ratingowe, izby rozliczeniowe). Ci pośrednicy sami nie inwestują na rynku finansowym, lecz organizują ten rynek.

Ryzyko kredytowe i ryzyko wypłacalności pierwszej grupy mitygowane jest systemowo przez sieć bezpieczeństwa finansowego i system gwarantowania depozytów (Karkowska, 2015). W podrozdziale ósmym wskazano na fenomen rozwoju trzeciej grupy pośredników finansowych, działających w modelu platform dwu- i wielostronnych i czerpiących z nowych technologii i zasięgu Internetu. Zarabiają oni na prowizjach i z reguły nie ponoszą ryzyka kredytowego, wykonując swoją funkcję pośrednika finansowego.

Bilans pośredników finansowych, podobnie jak każdego innego podmiotu, zestawia zasoby. Zasób gospodarczy to kategoria ekonomiczna, która odzwierciedla wartość na dany moment w czasie, strumien zaś oddaje wartość w okresie (np. zysk osiągany przez rok obrotowy). Kategorie ekonomiczne zasobów i strumieni się przenikają. W systemie finansowym wypracowane oszczędności tworzą w danym momencie kapitał, przechowywany w pieniądzu, ale podlegający przekształceniu $\mathrm{w}$ różne niepieniężne instrumenty finansowe w procesie transformacji oszczędności w inwestycje. Zamianę strumienia $\mathrm{w}$ zasób ilustruje następujący przykład: zysk spółki, jeśli nie zostanie wypłacony akcjonariuszom na mocy decyzji walnego zgromadzenia, zostaje w spółce i jest dopisywany do jej kapitałów.

Budżet zestawia strumienie (wpływy i wydatki). Do głównych składowych sprawozdania finansowego podmiotu gospodarczego należą rachunek zysków i strat (wyników) oraz rachunek przepływów pieniężnych. Budżet zestawiony ex post metodą memoriałową to rachunek zysków i strat, natomiast budżet zestawiony ex post metodą kasową to rachunek przepływów pieniężnych.

\section{Pieniądz i niepieniężne instrumenty finansowe}

Instrument finansowy spełnia podstawową zasadę rachunkowości, tj. zasadę podwójnego zapisu. Występuje z jednej strony w pasywach emitenta, z drugiej zaś - w aktywach inwestora (Górski, 2018, s. 21). Pieniądz jest instrumentem finansowym o największym stopniu płynności, jest płynno- 
ścią sam w sobie. M. Górski definiuje pieniądz wiązką funkcji, jakie ten pełni (środek płatniczy, pośrednik wymiany, środek tezauryzacji, miernik wartości). Niepieniężne instrumenty finansowe (obligacje, depozyty, akcje itp.) mają niższy stopień płynności, ale niektóre z nich na tyle wysoki, że władza monetarna (bank centralny) zalicza je do oficjalnych agregatów pieniężnych (vide składowe mierników M2, M3, tzw. pieniądza w ujęciu szerokim).

Agregat pieniężny M1 (tzw. pieniądz w ujęciu wąskim), zestawiany dla poszczególnych walut narodowych, tworzą pieniądz gotówkowy, bezgotówkowy i elektroniczny. Aktualnie budzące szerokie zainteresowanie i dyskusje kryptowaluty nie wchodzą do agregatu pieniężnego M1. Nie są pieniądzem funkcjonującym $\mathrm{w}$ ramach walut narodowych i dwuszczeblowego systemu bankowego, chociaż mogą spełniać funkcje pieniądza w ograniczonym zakresie. Alternatywne waluty (altcoiny) nie stanowią składnika pasywów banku centralnego, banków komercyjnych, instytucji płatniczych czy instytucji pieniądza elektronicznego (Górka, 2013, s. 27). Najpopularniejsze z altcoinów, bitcoiny, kreowane są w procesie kopania (mining), który można porównać $\mathrm{z}$ wydobywaniem złota. Podaż złota jako nieodnawialnego zasobu naturalnego określona jest przez ilość tego kruszcu na kuli ziemskiej i zależy od mocy oraz kosztów wydobycia. Podobnie, system Bitcoin nie ma centralnego emitenta. Bitcoiny nie figurują w pasywach żadnego podmiotu. Sa pasywem systemu. Podaż bitcoinów jest określona zasadami wyznaczonymi przez twórców systemu, algorytmem rozproszonej sieci opartej na łańcuchu bloków (blockchain). Podaż bitcoinów rośnie w malejącym tempie, czyli ma wbudowany mechanizm deflacyjny. Rosną też koszty kreacji bitcoinów. Limit emisji określony przyjętymi zasadami i wsparty algorytmem systemu Bitcoin wynosi 21 milionów bitcoinów (Górka, 2013, p. 1.3.).

M. Górski (2018, s. 31-32) dzieli instrumenty finansowe wg pięciu kryteriów odnoszących się do trzech najistotniejszych cech (atrybutów) instrumentów finansowych: płynności, ryzyka i dochodowości. Tymi kryteriami są:

1) rodzaj reprezentowanego prawa przez instrument,

2) sposób przenoszenia tytułu własności instrumentu,

3) termin i sposób wykupu instrumentu (termin wymagalności/zapadalności),

4) rodzaje dochodów związanych $\mathrm{z}$ instrumentem,

5) sposób naliczania dochodu i ustalania wartości instrumentu.

Podział instrumentów finansowych wg pierwszego kryterium przedstawia się następująco: 
- dłużne (m.in. obligacja, bon, list zastawny, kredyt, pożyczka, depozyt, weksel, czek, gotówka, pieniądz elektroniczny),

- udziałowe (akcja, udział, księga wieczysta, prawo poboru, prawo do akcji, kwit depozytowy ADR/GDR),

- powiernicze (jednostka uczestnictwa, certyfikat inwestycyjny, jednostka rozrachunkowa)

Każdy z instrumentów dłużnych jest wierzytelnością (należnością) jego posiadacza (właściciela, inwestora) a zobowiązaniem emitenta. Wierzytelności stają się zapadalne a zobowiązania wymagalne $\mathrm{w}$ terminie wykupu instrumentu dłużnego, kiedy dłużnik zwraca kapitał wraz z odsetkami wierzycielowi.

M. Górski podkreśla, że definicja legalistyczna (tj. zamieszczona w akcie prawnym) instrumentu finansowego lub papieru wartościowego bywa przydatna, ale nie jest konieczna do jego występowania. Za przykład może posłużyć klasyczny papier komercyjny (krótkoterminowy bon przedsiębiorstw), który nie został zdefiniowany $\mathrm{w}$ polskim prawodawstwie, a jednak funkcjonował. Jego emisje odbywały się w oparciu o różne akty prawne: prawo wekslowe, ustawę o obligacjach, kodeks cywilny.

Praktyka gospodarcza jest złożona, pojawia się potrzeba tworzenia innowacji finansowych, w tym hybrydowych i złożonych konstrukcyjnie instrumentów finansowych. Tak powstały instrumenty pochodne, a ostatnio produkty strukturyzowane (więcej o tych ostatnich w: Kobus, 2008), które są połączeniem co najmniej dwóch instrumentów finansowych (np. obligacji zerokuponowej i opcji na WIG20).

Wielokryterialna klasyfikacja instrumentów finansowych pozwala lepiej pojąc naturę każdego z instrumentów. Natomiast połączona z analizą bilansów podmiotów i ryzyka wg podejścia M. Górskiego ułatwia zrozumienie skomplikowanych operacji finansowych - np. sekurytyzacji przeprowadzanej za pomocą papierów wartościowych emitowanych na strumieniach gotówki generowanej przez aktywa. Sekurytyzacja polega na zamianie niepłynnych aktywów w papiery wartościowe. Jest jednym ze źródeł finansowania podmiotu inicjującego proces sekurytyzacji i wyodrębniającego jednorodne aktywa ze swojego bilansu. Sekurytyzowane papiery wartościowe określane są mianem ABS (Asset Backed Securities). Ich podkategorię stanowią MBS (Mortgage Backed Securities) tworzone na należnościach z kredytów zabezpieczonych hipoteką. Na skutek sekurytyzacji kredytów następuje transfer ryzyka z banków na inwestorów kupujących papiery wartościowe na rynku kapitałowym. 
Lekcja z kryzysu finansowego roku 2008 mówi, że nawet wyrafinowana inżynieria finansowa zastosowana $\mathrm{w}$ sekurytyzowanych papierach wartościowych nie pozwala abstrahować od jakości instrumentu bazowego. Materializacja ryzyka kredytowego aktywów bazowych, w tym przypadku kredytów hipotecznych niskiej jakości (subprime) udzielonych osobom o niskiej zdolności kredytowej, wywołała falę negatywnych skutków: spadek wartości sekurytyzowanych papierów na globalnych rynkach kapitałowych, straty banków i inwestorów, zahamowanie emisji nowych tego typu instrumentów, efekt zarażenia, kryzys płynności i ogólny spadek zaufania między instytucjami finansowymi i inwestorami (więcej Waszkiewicz, 2010; Pawłowicz, 2018).

\section{Triada atrybutów instrumentów finansowych}

Zgodnie z ustawą z dnia 29 lipca 2005 r. o obrocie instrumentami finansowymi pojęcie „instrumentu finansowego" jest szersze od pojęcia „papieru wartościowego", chociaż oba pojęcia w określonym kontekście bywają stosowane zamiennie.

Instrument finansowy jest walorem, który reprezentuje prawo majątkowe o charakterze finansowym. Stanowi prawo własności kapitału pieniężnego. Inkorporuje prawa i obowiązki, wierzytelności i zobowiązania inwestorów i emitentów. W kategoriach strumienia ekonomicznego i prawa własności, instrument finansowy można rozumieć jako prawo do przyszłego dochodu obciążone ryzykiem. Inwestor ma nadzieję na osiągnięcie dodatniej stopy zwrotu, ale oczekiwany dochód może nie zostać zrealizowany, ponieważ z każdą inwestycją związane jest ryzyko. „Na rynkach finansowych dokonuje się zamiana płynności na oczekiwany, lecz obciążony ryzykiem, dochód z instrumentu finansowego" (Górski, 2018, s. 30).

Jak podkreśla M. Górski, każdy instrument finansowy powinien być charakteryzowany i analizowany przez trzy parametry, cechy, które stanowią triadę jego atrybutów: płynność, ryzyko, dochód. Płynność mierzymy łatwością (szybkością i kosztem) zamiany instrumentu finansowego na pieniądz, ryzyko - odchyleniem standardowym (wariancją) ceny instrumentu od jego średniej w danym okresie (obliczanym na podstawie historycznych danych o określonej częstotliwości, np. dziennej lub rocznej), dochód - stopą zwrotu (dochód do ceny/wartości zakupu instrumentu finansowego). 
Pomiędzy płynnością a ryzykiem istnieje korelacja ujemna (im bardziej płynny instrument finansowy, tym niższe ryzyko i vice versa), pomiędzy ryzykiem a dochodem istnieje natomiast korelacja dodatnia (im wyższe ryzyko, tym wyższa oczekiwana potencjalna stopa zwrotu i vice versa). Ważny jest kierunek wpływu oddający zależność przyczynowo-skutkową.

Te parametry (zazwyczaj explicite ryzyko i dochód, implicite płynność) są brane pod uwagę w modelach analizy portfela instrumentów finansowych, np. w popularnym modelu wyceny aktywów kapitałowych (Capital Asset Pricing Model) i we wskaźnikach stosowanych do oceny efektywności inwestycji - m.in. wskaźnikach Sharpe’a, Treynora, Alfa Jensena czy wreszcie Górskiego (por. Damodaran, 2002; Jajuga i Jajuga, 2011; Sopoćko, 2018; Górski i in., 2007). Analiza inwestycji w aktywa finansowe uwzględniająca trzy cechy instrumentów finansowych pozwala podejmować świadome decyzje inwestycyjne i uchronić się przed ryzykiem utraty kapitału. W ostatnim czasie wielu inwestorów, skuszonych obietnicą ponadprzeciętnej stopy zwrotu, kupowało wysoko oprocentowane obligacje spółki GetBack, nie bacząc na ryzyko towarzyszące inwestycji. W drugim kwartale 2018 r. spółka stanęła na krawędzi bankructwa. Inwestorzy mogą nie tylko nie zrealizować wysokiej stopy zwrotu, ale w negatywnym scenariuszu wielu z nich może nie odzyskać nawet zainwestowanego kapitału.

\section{Rynki finansowe}

Instrumenty finansowe są emitowane, kupowane i sprzedawane na rynku finansowym. Stosując mieszane kryterium podziału ze względu na przedmiot obrotu i termin wykupu instrumentu, M. Górski (2018, rozdz. 11) dzieli rynki finansowe na: walutowe, pieniężne (termin zapadalności/wymagalności instrumentu do roku) i kapitałowe (termin zapadalności/wymagalności instrumentu powyżej roku). Cechą charakterystyczną tego podziału jest wyodrębnienie rynku walutowego z rynków pieniężnych. Rynek instrumentów pochodnych ujmowany jest w ramach rynków kapitałowych.

Najmniej regulowanym rynkiem jest rynek walutowy, najbardziej regulowany jest obrót papierami wartościowymi na rynku giełdowym. M. Górski eksponuje rolę międzybankowego rynku pieniężnego, na którym wyznaczana jest rynkowa cena pieniądza, w Polsce stawkami WIBOR i WIBID dla depozytów o różnym terminie (od jednodniowych po roczne). Na tym rynku banki wymieniają się płynnością, negocjując bilateralnie stawki oprocento- 
wania wnoszonych i przyjmowanych depozytów. Stawki WIBOR i WIBID zależą od stóp procentowych banku centralnego (silnie korelując m.in. ze stopą referencyjną), same zaś stanowią stopę odniesienia dla innych stóp w gospodarce (np. bezpośrednio determinują oprocentowanie kredytów detalicznych, ponieważ często w umowach kredytów hipotecznych oprocentowanie jest ustalane jako WIBOR $3 \mathrm{M}+$ marża banku).

\section{Rysunek 3. Rodzaje rynków finansowych}

\begin{tabular}{|c|c|c|}
\hline \multicolumn{3}{|c|}{ RYNEK FINANSOWY } \\
\hline $\begin{aligned} & \text { Rynek walutowy } \\
& \text { - rynek międzynarodowy } \\
& \text { - rynek krajowy hurtowy } \\
& \text { - rynek krajowy detaliczny }\end{aligned}$ & $\begin{array}{l}\text { Rynek pieniężny } \\
\text { - rynek depozytów } \\
\text { krótkoterminowych } \\
\text { - rynek kredytów } \\
\text { obrotowych } \\
\text { - rynek weksli handlowych } \\
\text { - międzybankowy rynek } \\
\text { pieniężny } \\
\text { - rynek bonów skarbowych }\end{array}$ & $\begin{array}{l}\text { Rynek kapitałowy } \\
\text { - rynek depozytów } \\
\text { długoterminowych } \\
\text { - rynek kredytów } \\
\text { długoterminowych } \\
\text { - rynek pozabankowych } \\
\text { instytucji finansowych: } \\
\text { polisy ubezpieczeniowe } \\
\text { na życie, instrumenty } \\
\text { funduszy inwestycyjnych } \\
\text { - rynek papierów } \\
\text { wartościowych (w tym } \\
\text { giełda) }\end{array}$ \\
\hline
\end{tabular}

Źródło: Górski, 2018, s. 295

Rynek finansowy dzieli się też na pierwotny i wtórny. Na rynku pierwotnym powiększeniu ulega bilans emitenta o wartość wyemitowanego instrumentu finansowego (dłużnego lub udziałowego). Zobowiązanie bądź kapitał udziałowy (właścicielski) pojawia się w pasywach emitenta, natomiast środki pieniężne uzyskane ze sprzedaży instrumentu są zapisywane w jego aktywach. W bilansie inwestora następuje zmiana struktury aktywów, nie ulega zmianie suma bilansowa. W miejsce środków pieniężnych pojawia się niepieniężny instrument finansowy.

$\mathrm{Na}$ rynku wtórnym odbywa się obrót już wyemitowanymi instrumentami finansowymi, niewpływający na sumę bilansową żadnego z inwestorów, tym bardziej na sumę bilansowa emitenta (ta skraca się dopiero w momencie wykupu bądź umorzenia instrumentu finansowego). Na rynku wtórnym zmianie ulega tylko struktura aktywów inwestora będącego sprzedawcą instrumentu $\mathrm{i}$ inwestora będącego kupcem instrumentu (wymiana pieniądz za niepieniężny instrument finansowy). 
Rynki finansowe są powiązane z rynkami realnymi. Dobra i usługi rynków realnych są w dużym stopniu wytwarzane dzięki finansowaniu pozyskanemu na rynkach finansowych.

\section{System finansowy w ujęciu perspektywicznym}

Jakie jest ratio istnienia pośredników finansowych? Pośrednik zarabia na swojej głównej funkcji, przekazując kapitał między podmiotami i przekształcając oszczędności w inwestycje (np. bank czerpie dochody odsetkowe na różnicy oprocentowania depozytów i kredytów). Czy nie taniej i szybciej byłoby transferować kapitał bezpośrednio między kapitałodawcami a kapitałobiorcami z pominięciem pośredników finansowych?

Ratio (powód, przesłanka) istnienia pośredników finansowych wynika z:

- redukowania kosztów transakcyjnych i asymetrii informacji,

- zdolności do agregacji popytu i podaży,

- profesjonalizmu i specjalizacji,

- przejęcia lub zarządzania ryzykiem (kredytowym i innymi rodzajami ryzyka),

- skali działania.

Koszt poszukiwania drugiej strony transakcji (dawca kapitału poszukujący potencjalnego biorcy i odwrotnie), koszt negocjacji warunków kontraktu, koszt analizy ryzyka kredytowego, koszt monitorowania i zarządzania ryzykiem spłaty pożyczki, to są koszty transakcyjne dawców i biorców kapitału w rozumieniu Coase’a i Williamsona (1981), które pośrednicy finansowi istotnie redukują. Zdolność do agregacji popytu i podaży stanowi o wartości i skuteczności pośredników finansowych w transferze kapitału. Ponadto, są oni profesjonalnymi instytucjami, wyspecjalizowanymi w swojej działalności. Często przejmują na siebie za opłatą ryzyko kredytowe lub zarządzają nim w adekwatny sposób (vide podział pośredników finansowych ze względu na sposób transferu ryzyka kredytowego na inwestorów w podrozdziale czwartym „Model finansowy i ryzyko pośrednika finansowego”). Skala działania pozwala pośrednikom ograniczyć koszty stałe, wpływając na efektywność ich biznesu i efektywność samego procesu transformacji kapitału.

Jednakże w ostatnim czasie sektor pośrednictwa finansowego podlega przeobrażeniu na skutek rozwoju Internetu i technologii oraz wzrostu powiązań w globalnej gospodarce. Dzięki internetowi i elektronicznym sieciom łączności łatwiej się komunikować i organizować platformy kojarzące 
podmioty o zbieżnych interesach, przykładowo dawców i biorców kapitału, sprzedających i kupujących, piszących i użytkujących programy komputerowe. Tak funkcjonują rynki dwustronne (two-sided markets; Górka, 2009). Należy zdawać sobie sprawę, że platformy też są pośrednikiem (niektóre są finansowym), realizującym dochody prowizyjne, często w skomplikowanym modelu opłat pobieranych od obu stron rynku (vide giełdy finansowe, systemy płatności kartowych jak Visa i Mastercard, serwisy aukcji internetowych jak eBay, Amazon, Allegro, mobilne systemy operacyjne jak Android, iOS). Siła platform, podobnie jak tradycyjnych pośredników finansowych, tkwi w agregacji popytu i podaży.

Dynamicznie rozwija się branża FinTech (financial technology), czyli usługi finansowe świadczone przy użyciu nowych technologii (Szpringer, 2017). FinTech wkracza w każdą dziedzinę pośrednictwa finansowego, od płatności, pożyczek, do ubezpieczeń i inwestycji, chociaż największe finansowanie i najwięcej innowacji pojawia się w płatnościach i pożyczkach społecznościowych. Skalę inwestycji w branżę FinTech oddaje powściągliwy szacunek Capgemini, LinkedIn i Efma (2018, s. 45): od 2009 do 2017 firmy fintechowe otrzymały ok. 110 miliardów dolarów finansowania. Celem podmiotów sektora FinTech jest świadczyć daną usługę finansową taniej, szybciej i wygodniej niż w tradycyjny sposób (Górka, 2017). Innowacje finansowe mają miejsce w środowisku cyfrowym. Rodzi to konieczność sprostania cyberzagrożeniom i stosowania coraz doskonalszych metod zarządzania ryzykiem operacyjnym.

Pojawiają się nowe formy finansowania: crowdfunding i ICO (Initial Coin Offering), czyli, odpowiednio, finansowanie społecznościowe i finansowanie poprzez emisję w technologii łańcucha bloków (blockchain) tokenów lub monet kryptowaluty. Firmy za pośrednictwem internetowych platform crowdfundingowych (np. Kickstarter, Indiegogo) lub internetowych platform ICO (np. Waves lub NXT Platform) są w stanie w krótkim czasie pozyskać od inwestorów globalnych znaczny kapitał, na poziomie kilkuset milionów do nawet kilku miliardów dolarów (Górka i Pietruk, 2018).

Jako bezpośredni konkurenci banków depozytowo-kredytowych rozwinęły się platformy pożyczek społecznościowych (social lending, P2P lending) kojarzące pożyczkodawców (dawców kapitału) z pożyczkobiorcami (biorcy kapitału). Pożyczki społecznościowe mogą być kwalifikowane do crowdfundingu dłużnego. W klasycznym modelu platforma umożliwiająca pożyczki społecznościowe dokonuje zautomatyzowanej oceny zdolności kredytowej pożyczkobiorcy, klasyfikuje pożyczkobiorcę do danej grupy ryzyka i pomaga zdywersyfikować ryzyko kredytowe pożyczkodawcy poprzez rozproszenie 
jego inwestycji między różnych pożyczkobiorców. Pionierzy rynku pożyczek społecznościowych działają już od kilkunastu lat (brytyjska ZOPA i amerykański Prosper od 2005 r., amerykański Lending Club od 2007 r., chiński Lufax od 2011 r.).

Obecnie coraz częściej mówi się o tzw. gospodarce współdzielenia (sharing economy), w której podmioty współdzielą swoje zasoby (Poniatowska-Jaksch i Sobiecki, 2016). Nie dotyczy to jedynie sektora finansowego i branży FinTech. Ekosystem plug-and-play rozwija się w każdej dziedzinie gospodarki (m.in. w transporcie - np. Uber, Panek, hotelarstwie np. Booking.com, turystyce - np. Tourzan). Instytucje wzajemnie korzystają w czasie rzeczywistym i na odległość ze swoich zasobów i funkcjonalności udostępnianych za pośrednictwem interfejsów technicznych (tzw. API, Application Programming Interface). Komunikacja przez API odbywa się bez interwencji człowieka, w sposób zaprogramowany i zautomatyzowany. Innowacyjne podmioty mają też do dyspozycji infrastrukturę chmury, narzędzia uczenia maszynowego i sztucznej inteligencji oraz takie technologie jak blockchain.

Model działania w oparciu o zasoby i funkcjonalności firm trzecich pozwala stworzyć nową usługę finansową taniej i szybciej niż w oparciu tylko o własne zasoby (Górka, 2017). Przykładowo, w Polsce pozabankowe instytucje pożyczkowe rynku consumer finance działające w środowisku internetowym, takie jak Wonga lub Vivus badają zdolność kredytową klienta, korzystając z zewnętrznych baz danych BIK (Biuro Informacji Kredytowej), KRD (Krajowy Rejestr Długów), ERIF Biuro Informacji Gospodarczej, a także do credit scoringu pozyskują dane o historii rachunku bankowego klienta, wykorzystując usługi agregujące informacje (firm fintechowych Kontomatik i Instantor).

W Unii Europejskiej usługę informacji o rachunku płatniczym (AIS, account information service) i usługę inicjowania płatności (PIS, payment inititation service) reguluje druga dyrektywa o usługach płatniczych (PSD2, revised Payment Services Directive), która weszła w życie w 2018 r. Ten rewolucyjny akt prawny toruje drogę otwartej bankowości (Kasiewicz, 2018; Górka, 2016). Dzięki niej należy się spodziewać wzrostu konkurencji na rynku usług płatniczych, bankowych i finansowych. Podmioty trzecie, w tym banki, małe niebankowe FinTechy lub giganci technologiczni tacy jak Google czy Apple, będą mogły uzyskać za zgodą klienta:

- dostęp do jego cennych zasobów (tj. danych finansowych) w bankach prowadzących jego rachunki płatnicze;

- możliwość transferowania środków pieniężnych z tych rachunków. 
Można sobie wyobrazić taką przykładowo sytuację, gdy z poziomu interfejsu wybranego banku (bankowość elektroniczna lub aplikacja mobilna), posiadacz rachunku płatniczego będzie mógł zlecać płatności i zarządzać swoimi rachunkami we wszystkich bankach. Podmioty niebankowe natomiast będą mogły uzupełnić swoje usługi lub kreować nowe, wykorzystując otwartą bankowość, i w ten sposób konkurując z bankami na polu produktów bankowych (więcej o ekwilibirium współpracy i konkurencji w gospodarce współdzielenia między bankami, FinTechami a spółkami technologicznymi w: Górka, 2018). Usługi AIS i PIS zostały obudowane ścisłymi ramami prawnymi regulującymi prawa i obowiązki wszystkich stron usługi i mającymi zapewnić bezpieczeństwo i pewność operacji. Aktualnie trwa w bankach proces budowania API dla usług AIS i PIS. Zgodnie z wymogami PSD2 muszą być one gotowe do września 2019 r.

Rozwój technologii wpływa także na rynki finansowe. Na Wall Street, ale i na GPW w Warszawie coraz częściej zamiast ludzi inwestują zaprogramowane roboty stosujące algorytmy i kierujące się skomplikowanymi strategiami inwestycyjnymi. Roboty te są w stanie w czasie rzeczywistym przetwarzać duże ilości danych i natychmiast reagować na sygnały inwestycyjne płynące z rynku (tzw. handel algorytmiczny, algo-trading).

Powstaje pytanie, jaki wpływ nowe technologie (sztuczna inteligencja, algorytmy, roboty, API) i cała branża FinTech będą miały na gospodarkę i stabilność finansową. Legislatorzy i nadzorcy, dbając o bezpieczeństwo finansowe i operacyjne, wprowadzają ciągle nowe regulacje, de facto wywołując tsunami aktów prawnych i być może brnąc w ślepy zaułek, jak dowodzi K. Kalicki (2018). Krańcowy koszt regulacji usług bankowych może już bowiem przekraczać krańcową korzyść wynikającą ze wzrostu bezpieczeństwa banków. W ten sposób regulatorzy przyczyniają się do wejścia w obszar działania sektora pośrednictwa finansowego podmiotów z innych branż, które mają technologię, innowacyjne pomysły i wdrażają rozwiązania w nowym modelu. Wpływ na konkurencyjność i innowacyjność rynku powinien być zatem pozytywny. Praktyka jednak pokazuje, że rozmiar obciążeń regulacyjnych rośnie także w przypadku startupowych Fintechów, które dysponują znacznie mniejszymi zasobami i możliwościami udźwignięcia nowych obciążeń. Być może zatem ewolucja ta nie prowadzi do stanu konkurencji doskonałej, lecz utrwala dominację dużych instytucji. Jedną z odpowiedzi na wzrastająca liczbę regulacji jest RegTech (regulatory technology), czyli technologie, które poprzez automatyzację i algorytmizację pozwalają obniżyć koszty dostosowania do przepisów prawa. 


\section{Synteza klasycznego ujęcia M. Górskiego i ujęcia perspektywicznego, implikacje zmian systemu finansowego}

Klasyczne podejście M. Górskiego do systemu finansowego akcentuje:

- istotę efektywnej transformacji kapitału w systemie finansowym gospodarki dokonywanej za pomocą instrumentów finansowych przez pośredników finansowych na rynkach finansowych;

- rolę w systemie finansowym dawców i biorców kapitału, gospodarstw domowych (wierzyciele netto), przedsiębiorstw i państwa (dłużnicy netto);

- dualne postrzeganie instrumentów finansowych (pasywo jednego podmiotu, aktywo drugiego podmiotu) i triadę atrybutów instrumentów finansowych (płynność, ryzyko, dochód);

- strukturę bilansu pośredników finansowych, charakter kapitałów i majątku;

- znaczenie ryzyka w działalności pośredników finansowych, inwestorów i emitentów instrumentów finansowych;

- bogactwo rodzajowe pośredników finansowych i rynków finansowych.

$\mathrm{Na}$ system finansowy można spojrzeć przez pryzmat transformacji pośrednictwa finansowego przejawiającej się m.in.:

- postępującą cyfryzacją i zastosowaniem nowych technologii (API, uczenie maszynowe, sztuczna inteligencja, robotyzacja, chmura obliczeniowa, blockchain itp.);

- dynamicznie rozwijającą się branżą FinTech;

- nowymi modelami biznesu;

- współdzieleniem zasobów, wykształcającą się gospodarką współdzielenia;

- nowymi formami finansowania: crowdfunding i ICO;

- otwartą bankowością, rozwojem usług informacji o rachunku i inicjacji płatności (AIS i PIS, ważna rola dyrektywy PSD2 w Europie);

- handlem algorytmicznym;

- tsunami regulacyjnym.

Uwarunkowania społeczno-gospodarcze, kreacja innowacji, rozwój technologiczny, ponadnarodowy charakter nowych rozwiązań mają swoje dalekosiężne konsekwencje dla systemu finansowego: 
- przyspiesza proces transformacji kapitału i szybkość obiegu pieniądza;

- rośnie skala powiązań między podmiotami i współzależność podmiotów, które współdzielą swoje zasoby i wzajemnie korzystają z usług i funkcjonalności, wpływając tym samym na rozkład i rozmiar ryzyka;

- na znaczeniu zyskują platformy działające w modelu rynków dwustronnych;

- pogłębia się globalizacja rynków finansowych, biznesu, transferu kapitału;

- rośnie konkurencja na rynku usług finansowych i innowacyjność podmiotów;

- usługi finansowe zaczynają świadczyć podmioty spoza tradycyjnego grona pośredników finansowych;

- zacierają się granice branżowe działania pośredników finansowych;

- rośnie ilość danych i szum informacyjny;

- usługi finansowe świadczone są w coraz bardziej rozbudowanych modelach wymagających zaangażowania wielu podmiotów, a to prowadzi do wytworzenia skomplikowanego systemu praw i obowiązków i wpływa na ryzyko systemowe i stabilność finansową;

- powstają hybrydowe i złożone instrumenty finansowe;

- rośnie w szybkim tempie liczba regulacji w odpowiedzi na nowe zagrożenia i z chęci zwiększenia bezpieczeństwa obrotu finansowego.

\section{Podsumowanie}

W rozdziale zaprezentowano filary podejścia M. Górskiego charakteryzującego system finansowy przez pryzmat instrumentów finansowych, podmiotów systemu finansowego i rynków finansowych. Następnie skoncentrowano się na zmianach sektora pośrednictwa finansowego związanych z cyfryzacją, rozwojem technologii i Internetu, ewolucją potrzeb społeczno-gospodarczych, innowacjami finansowymi i nowymi modelami biznesowymi. System finansowy podlega dynamicznej transformacji o rosnącym stopniu złożoności i globalnym charakterze. Stwarza to wyzwania regulacyjne w wymiarze ponadnarodowym. Jednocześnie można zaobserwować wysoką adaptowalność podmiotów systemu finansowego, które elastycznie modyfikują modus operandi.

Wnioskiem z przeprowadzonej analizy jest, że w zmieniających się warunkach społeczno-gospodarczych klasyczne podejście M. Górskiego odgrywa ważną rolę porządkującą i objaśniającą. Jego mocną stroną jest holizm. 
Pozwala zrozumieć pryncypia systemu finansowego oraz naturę transferu kapitału, które pozostają niezmienne. Ujęcie systemu finansowego przez M. Górskiego można z powodzeniem rozwijać i łączyć w szerszej perspektywie badawczej. W rozdziale zadano pytania oraz wskazano godne eksploracji obszary badawcze.

\section{Literatura}

Begg, D., Vernasca, G., Fisher, S. i Dornbusch, R. (2014). Makroekonomia. Warszawa: PWE,.

Capgemini, LinkedIn i Efma. (2018). World FinTech Report 2018. Pozyskano z: https://www. capgemini.com/wp-content/uploads/2018/02/world-fintech-report-wftr-2018.pdf.

Damodaran, A. (2002). Investment Valuation: Tools and Techniques for Determining the Value of Any Asset. New York: Wiley.

Friedman, M. (1992). Money Mischief: Episodes in Monetary History. San Diego, New York, London: A Harvest Book Harcourt Brace \& Company.

Górka, J. (2009). Konkurencyjność form pieniądza i instrumentów platniczych. Warszawa: Wydawnictwo CeDeWu.

Górka, J. (2013). Efektywność instrumentów platniczych w Polsce. Warszawa: Wydawnictwo Naukowe Wydziału Zarządzania UW.

Górka, J. (2016). IBANs or IPANs? Creating a Level Playing Field between Bank and NonBank Payment Service Providers. W: J. Górka (red.), Transforming Payment Systems in Europe (s. 182-213). London: Palgrave Macmillan.

Górka, J. (2017). Fin-tech ZUS. Z Życia ZUS, 3(195).

Górka, J. (2018). Banki, GAFAM, FinTech w gospodarce współdzielenia - equilibrium współpracy i konkurencji. W: D. Dziawgo (red.), Prace Nankowe Uniwersytetu Ekonomicznego we Wroctawin (w druku).

Górka, J. i Pietruk, A. (2018). Nowe formy finansowania projektów inwestycyjnych i przedsiębiorstw: crowdfunding i ICO. Problemy Zarzadzania, 16(3/2).

Górski, M., Górka, J. i Winiarski, R. (2007). Realne stopy zwrotu inwestorów krajowych i zagranicznych z inwestycji finansowych w Polsce w latach 1994-2005. W: K. Ryć, M. Dusza (red.), Czynniki wzrostu gospodarczego w Polsce 2006+. Warszawa: Wydawnictwo Wydziału Zarządzania UW.

Górski, M. (2002/2018). Wyktady z „Pieniądza i rynków pieniężnych” i „Systemu finansowego gospodarki” w latach 2002-2018. Warszawa.

Górski, M. (2018). Rynkowy system finansowy. Warszawa: PWE.

Von Hayek, F. (2007). The Pure Theory of Capital. The University of Chicago Press Books.

Jajuga, K. i Jajuga T. (2011). Inwestycje. Instrumenty finansowe, aktywa niefinansowe, ryzyko finansowe, inżynieria finansowa. Warszawa: Wydawnictwo Naukowe PWN.

Jędrzejczak, G. (2018). Upadek gospodarki PRL trzydzieści lat później. O wyobraźni ekonomistów (w niniejszej książce).

Kalicki, K. (2018). Wptyw regulacji $i$ obciązen finansowych na sektor bankowy w UE $i$ w Polsce (w niniejszej książce).

Kamerschen, D., McKenzie, R., Nardinelli, C. (1993). Ekonomia. Gdańsk: Wyd. Fundacja Gospodarcza NSZZ „Solidarność”.

Karkowska, R. (2015). Ryzyko systemowe. Charakter i źródta indywidualizacji w sektorze bankowym. Warszawa: Wydawnictwo Wolters Kluwer. 
Kasiewicz, S. i Rogowski, W. (2009). Inwestycje bybrydowe - nowe njęcie oceny efektywności. Warszawa: Oficyna Wydawnicza Szkoły Głównej.

Kasiewicz, S. (2018). PSD2 krytyczny przystanek na drodze do nowej ery bankowości. Warszawa: Oficyna Wydawnicza Szkoły Głównej Handlowej.

Kobus, M. (2008). Produkty strukturyzowane na rynku finansowym w Polsce. Praca doktorska pod kierunkiem M. Górskiego obroniona na Wydziale Zarządzania Uniwersytetu Warszawskiego.

Von Mises, L., (2012). Teoria pieniadza i kredytu. Warszawa: Wydawnictwo Fijorr Publishing.

Olszak, M. (2018). Rezerwy na ryzyko kredytowe w standardach adekwatności kapitatowej (w niniejszej książce).

Pawłowicz, L. (2018). Moral hazard w pośrednictwie finansowym (w niniejszej książce).

Poniatowska-Jaksch, M. i Sobiecki, R. (red.). (2016). Sharing Economy (gospodarka wospótdzielenia). Warszawa: Oficyna Wydawnicza SGH.

Solarz, J. (2014). Shadow banking. Systemowa innowacja finansowa. Łódź-Warszawa: Wydawnictwo Społecznej Akademii Nauk.

Sopoćko, A. (2018). Rynkowe instrumenty finansowe. Warszawa: Wydawnictwo Naukowe PWN.

Szpringer, W. (2017). Nowe technologie a sektor finansowy. FinTech jako szansa i zagrożenie. Warszawa: Wydawnictwo Poltext.

Waszkiewicz, A. (2010). Sekurytyzacja a kryzys subprime, Zarządzanie Zmianami: zeszyty naukowe, 1, 3-21.

Williamson, O. (1981). The Economics of Organization: The Transaction Cost Approach. The American Journal of Sociology, 87(3), 548-577.

Żyżyński, J. (2018). Pieniądz a instytucje finansowe (w niniejszej książce). 


\section{„PROFESOR MARIAN GÓRSKI W MOICH OCZACH”}

Notki $i$ wspomnienia 



\section{ANNA BIELECKA}

\section{Profesor Marian Górski w moich oczach...}

Początek lat 90., transformacja $\mathrm{w}$ kraju, w gospodarce, transformacja na Wydziale Zarządzania i... ogromne wyzwania, jakie stają przed prof. Marianem Górskim - właśnie wybranym przez Radę Wydziału na Dziekana - oraz sformułowanym przez niego kolegium, prodziekanami: do spraw współpracy z zagranicą - nieżyjącym już profesorem Stefanem Kwiatkowskim; do spraw naukowych - profesorem Stanisławem Piątkiem i do spraw studenckich moją skromną osobą, dr Anną Bielecką.

To, co piszę w niniejszym wspomnieniu, dedykuję pokoleniu, dla którego podróżowanie bez paszportu; informacja o kursach akcji na właśnie zakończonej sesji na giełdzie oddalonej o tysiące kilometrów; wykonanie profesjonalnej prezentacji $\mathrm{w}$ dowolnym edytorze, $\mathrm{z}$ wykorzystaniem dowolnego pakietu komputerowego itp., itd. wszystko to chleb powszedni.

Realia tamtych czasów na Wydziale Zarządzania UW to przestarzały, nieadekwatny do oczekiwań ze strony rynku pracy, program studiów; wykładowcy, korzystający w znacznym stopniu w pracy dydaktycznej tylko z tablicy i kredy; pomoce dydaktyczne - rzutniki z foliami, znajdujące się tylko w niektórych salach wykładowych; dziekanaty z mocno już zużytymi biurkami i regałami (design socjalistyczny), pamiętającymi jeszcze czasy początków WZ na Szturmowej. A wszystko w jednym budynku typu Lipsk, 5-piętrowym prostopadłościanie, wybudowanym $\mathrm{w}$ drugiej połowie lat siedemdziesiątych i mocno już wyeksploatowanym.

Pamiętam, jak na jednym z pierwszych kolegiów dziekańskich gorąco dyskutowana była kwestia koncepcji reformy programu studiów w kierunku powszechnego, indywidualnego toku studiów (student sam z oferowanych przez Wydział przedmiotów, tworzyłby własny program studiów). Na taką właśnie reformę programową zdecydowała się wówczas SGH (jeszcze jako Szkoła Główna Planowania i Statystyki). 
Ileż było spotkań, dyskusji, konsultacji, jakie Marian przeprowadził, komisji, jakie powołał, aby ostatecznie przedstawić Radzie Wydziału koncepcję reformy programu realizowanego w ramach istniejących już, ale także, a może przede wszystkim, w ramach nowych kierunków i specjalizacji. Za tymi zmianami szła gruntowna reforma treści programowych wykładanych przedmiotów. Najważniejszym zadaniem stało się dostosowanie programu nauczania do wymogów zmieniającej się gospodarki i rodzącego się biznesu. Położenie większego nacisku na praktyczny aspekt studiów, stopniowa komputeryzacja Wydziału z programami wspomagającymi proces dydaktyczny (wówczas dostępny był przede wszystkim Excel) - to chyba najważniejsze priorytety, jakie wyznaczył sobie Marian Górski w okresie zarówno pierwszej, jak i drugiej kadencji na stanowisku Dziekana.

Ale były również sprawy bardziej przyziemne, które udało się Marianowi i jego ekipie zrealizować, może nie aż tak ważne, ale istotne dla funkcjonowania Wydziału, administracji i studentów. Był to remont dziekanatów, nowe meble i... remont toalet(!).

A teraz dygresja bardziej osobista - moja znajomość z Marianem datuje się jeszcze z czasów studiów na Wydziale Ekonomii UW (wówczas Instytut Nauk Ekonomicznych, wcześniej Wydział Ekonomii Politycznej). Zarówno ja, jak i moje koleżanki zapamiętałyśmy wysokiego, zawsze elegancko ubranego, podziwianego ze względu na wiedzę i zaangażowanie (Koło Naukowe, ZSP) kolegę z wyższego roku studiów, a potem asystenta... 


\section{BEATA GLINKA}

\section{Pochwata racjonalności}

Profesora Mariana Górskiego poznałam ponad 20 lat temu. Muszę powiedzieć jednak, że moja wiedza o nim to pewien patchwork złożony z fragmentów bardzo różnych doświadczeń i skojarzeń.

Pierwsze skojarzenie z Profesorem Marianem Górskim już chyba nigdy się nie zmieni - podpis $\mathrm{w}$ indeksie, który otrzymałam, rozpoczynając pod koniec ubiegłego stulecia studia na Wydziale Zarządzania Uniwersytetu Warszawskiego. Profesor Górski był wtedy Dziekanem Wydziału, siłą rzeczy znaliśmy go więc, przynajmniej teoretycznie, wszyscy. Z praktyczną stroną tej znajomości było na samym początku nieco gorzej. Dziekan kojarzył mi się z dość poważnie, może nawet groźnie wyglądającym człowiekiem, chodzącym szybkim krokiem, z teczka, korytarzami budynku przy ulicy Szturmowej. Budynku typu Lipsk, o którego ówczesnej formie pamięć powoli niknie.

Tak czy inaczej, wśród studentów chodziły słuchy o jego groźnym charakterze i nieustępliwości, choć nie wszyscy mieli z nim bezpośrednio do czynienia. Widzieliśmy natomiast praktyczne efekty jego pracy jako Dziekana. Za jego kadencji na Wydziale uruchomiono Dyplomowe Studia Menedżerskie, które od początku zaczęły się cieszyć popularnością. Pamiętam, że po raz pierwszy pomyślałam wtedy o rzeczy oczywistej - że Wydziałem Zarządzania też warto dobrze zarządzać i przykłady takiego właśnie zarządzania zaczęłam dostrzegać.

Moje drugie skojarzenie pochodzi już z bieżącego stulecia, z czasów, kiedy zaczęłam chodzić na Rady Wydziału. Profesor - wtedy również przewodniczący Rady Nadzorczej jednego z dużych banków - był aktywnym członkiem Rady, ale nie oznaczało to, że mówił wiele i przy każdej okazji. Głos zabierał rozsądnie i wtedy, gdy miał coś do powiedzenia; tak zreszta jest do dziś. Pewnie dlatego obecnie z powodzeniem kieruje komisją Senatu UW zajmująca się finansami. 
Ostatnie skojarzenie, budzące zarazem zdziwienie dotyczące Profesora Górskiego, pochodzi z czasów, gdy kierował Studiami Doktoranckimi na Wydziale Zarządzania. Profesor Górski to znany ekonomista i specjalista od finansów. Przez lata widziałam w nim osobę o rozsądnych poglądach, ale jednocześnie przywiązaną do „ekonomizującego” podejścia do zarządzania, preferującą takie właśnie podejście do problemów badawczych i możliwych metod badań i analiz. To właśnie jednak za jego kadencji do programu studiów doktoranckich trafił kurs poświęcony badaniom jakościowym. Tak też zaczęła się moja współpraca ze studiami doktoranckimi. Kolejny raz doceniłam jego otwarte podejście do zarządzania.

Między innymi te kawałki wizerunku, o których wspomniałam, sprawiają, że uważam Profesora Górskiego za osobę, od której warto uczyć się racjonalności w podejściu do zarządzania. To warto obserwować i naśladować czego życzę sobie i studentom, których Profesor uczy. 


\section{Profesor Marian Górski w kontekście kilku epizodów}

Minęło już ponad czterdzieści lat od rozpoczęcia mojej pracy naukowej w Instytucie Organizacji i Kierowania UW i PAN, którego nazwa kilka lat później przekształciła się w Wydział Zarządzania Uniwersytetu Warszawskiego.

Rozpocząłem pracę jako profesor tytularny (wtedy istniały dwa tytuły profesorskie) cieszący się tytułem już od kilku lat. Przed przyjściem do Instytutu zostałem powołany na członka Centralnej Komisji Kwalifikacyjnej do spraw kadry naukowej. Nieco później funkcja ta okazała się użyteczna dla Instytutu i dla Wydziału.

Instytut był wówczas skromny pod względem obsady naukowej, zwłaszcza pod względem liczby samodzielnych pracowników naukowych. Jednakże względnie szybko sytuacja się poprawiła, dzięki nie tylko powiększeniu liczby samodzielnych pracowników naukowych, lecz także rozwojowi naukowych pracowników pomocniczych. Wtedy właśnie miałem możliwość poznać Mariana Górskiego z racji wspólnie prowadzonego tematu badawczego pn. „Denaturalizacja spożywcza artykułów żywnościowych”. Mariana oceniałem bardzo pozytywnie. Rozpoznałem w nim przyszłego profesora i tak się stało.

W mojej pamięci utkwiło także inne wydarzenie, kiedy w ramach projektu TEMPUS (Trans European Mobility Project for University Studies) udało się uzyskać zatwierdzenie projektu pn. „Centrum Kształcenia Menedżerskiego” (Centre for Management Training). Marian, jako Dziekan, nie odbierał tego faktu jako mojej próby odgrodzenia się od Wydziału. Jak się szybko okazało, pracownicy Wydziału Zarządzania, którzy umieli prowadzić wykłady w języku angielskim, choć nie przychodziło im to łatwo, pracowali wspólnie z profesorami z Europy Zachodniej. Dzięki temu w późniejszym okresie można było uruchomić program MBA oraz szereg innych kierunków (np. International 
Business). To właśnie tutaj pracownicy Wydziału zdobyli swoje doświadczenie dydaktyczne. Nastawienie Mariana jako Dziekana było przychylne.

Z satysfakcją wspominam współudział, z Dziekanem Harvard Business School, prof. Thomasem Piperem, w organizowaniu Central and Eastern European Teachers, Program dla wykładowców zarządzania z Polski. Miałem okazję zaproponować Marianowi uczestnictwo w tym programie. Był to program na bardzo wysokim poziomie, prowadzony przez cztery uniwersytety amerykańskie: Harvard University, Pensylvania University, North Western University, Stanford University, a ściślej biorąc: Harvard Business School, Wharton School, Kellogs School, Stanford School of Business. W pierwszym okresie program był przeznaczony dla uczestników z Polski. Jednakże już w trakcie drugiego roku został rozszerzony na pozostałe kraje postkomunistyczne. Walory programu najlepiej może przedstawić jego uczestnik. Jestem przekonany, że program przyczynił się do pogłębienia wiedzy z zakresu finansów i bankowości.

Last but not least, dołączam do tych kilku powyższych uwag gratulacje i życzenia z okazji 70. rocznicy urodzin Profesora Mariana Górskiego. 


\section{JAKUB GÓRKA}

\section{Profesor Marian Górski w moich oczach - profesor, preceptor, praktyk}

W towarzystwie Pana Profesora Górskiego przyjemnie jest przebywać, ponieważ roztacza aurę estymy i powagi, a zarazem tchnie spokojem i rozwagą. Kiedy trzeba, jest rzeczowy i konkretny, kiedy indziej - uśmiechnięty, żartobliwy, doskonale czuje się w nieformalnym anturażu. Sprawia wrażenie nieprzystępnego, lecz w bliższych relacjach okazuje się osobą życzliwą, przyjacielską i towarzyską. Zawsze zachowuje klasę.

Jego doświadczenie naukowo-dydaktyczne i praktyczne, a także osiągnięcia na tych polach budzą podziw. Ponadto jest obowiązkowy, dotrzymuje słowa, a dobro studentów, Wydziału i Uniwersytetu leży mu na sercu. Widać to doskonale po tym jak postępuje, prowadzi wykłady, prace dyplomowe, obrony, egzaminy, jak uczestniczy w pracach Rady Wydziału Zarządzania i Senatu Uniwersytetu Warszawskiego, kieruje Katedrą Systemów Finansowych Gospodarki i Zakładu Bankowości i Rynków Pieniężnych. Nawet w takich momentach, gdy wydaje się, że powinien przedłożyć i zadbać o swoje zdrowie, Profesor Górski wzorcowo wypełnia swoje zadania uczelniane i zawodowe. Od siebie oczekuje bardzo dużo, a i innym taryfy ulgowej nie daje. Studenci muszą się nauczyć do egzaminu, magistranci i doktoranci - napisać wartościowe prace. Profesor Górski jest otwarty..., ale na argumenty merytoryczne, natomiast gdy trzeba, ucina dyskusje. Koncentruje się na sednie, jak przystało na efektywnego menedżera, który umie posłużyć się brzytwą Ockhama.

I za to Go lubię i podziwiam! Za charyzmatycznym, mądrym i zdecydowanym liderem chce się podążać, słuchać jego poleceń, rad i sugestii.

Wiem, że w życiu prywatnym Profesor Górski jest ciepły i kochający. Najważniejsza dla niego jest rodzina - żona, synowie i wnuki. Dba o nich 
i otacza opieką. Umiał stworzyć dom rodzinny, do którego lgnie szerokie grono przyjaciól.

Pana Profesora Górskiego znam od ponad piętnastu lat. Będąc studentem trzeciego roku jednolitych studiów magisterskich prowadzonych na Wydziale Zarządzania Uniwersytetu Warszawskiego, słuchałem Jego wykładów z „Pieniądza i rynków pieniężnych” w roku akademickim 2001/2002. Zainspirowały mnie one i sprawiły, że wybrałem Profesora Górskiego na swojego promotora. Ale nie zapisałem się na Jego seminarium magisterskie w przewidzianym trybie, pod koniec trzeciego roku, ponieważ wówczas moje myśli zaprzątał wyjazd w ramach Erasmusa na Uniwersytet Lapoński w Rovaniemi. Dopiero po powrocie z koła podbiegunowego, krainy św. Mikołaja, w lutym roku 2003 zebrałem się na odwagę i poszedłem na dyżur Profesora Górskiego. Od wejścia wybąkałem, że chciałbym zapisać się do Niego na seminarium magisterskie. Profesor stwierdził, że termin zapisów minął ponad pół roku temu, ale zapytał, jaką ocenę miałem z egzaminu z Jego przedmiotu. Odparłem nieśmiało: - celujący (6, wówczas obowiązywała pięciostopniowa skala ocen). Profesor podniósł wzrok znad biurka, spojrzał na mnie badawczo, przebijając wzrokiem chmury dymu papierosowego zasnuwające Jego pokój, powiedział: - W takim razie nie mam reyboru, zapraszam na seminarium.

Od tego momentu trwa okres naszej współpracy. Miałem przyjemność i honor pisać zarówno pracę magisterską, jak i doktorską pod kierunkiem Pana Profesora Górskiego, korzystać z Jego pomocy merytorycznej, konsultować pomysły i działania, wygrywać konkursy i stypendia naukowe.

Pan Profesor napisał znakomitą książkę pt. Rynkowy system finansowy. Stale ją uaktualnia. Do tej pory nakładem Polskiego Wydawnictwa Ekonomicznego ukazały się cztery wydania, ostatnie w 2018 r. Jest to skarbnica usystematyzowanej wiedzy o systemie finansowym, przydatna teoretykom i praktykom gospodarczym. Książka ta stanowi główną pozycję literatury przedmiotów „System finansowy gospodarki” i „Bankowość” prowadzonych w Katedrze kierowanej przez Profesora Górskiego. Ciekawostką jest, że poszczególne rozdziały Pan Profesor opatrzył złotymi myślami, które dodają smaku zawartości merytorycznej, np. zobowiazania wydane z najpewniejszych rąk staja się pieniadzem; za posiadanie pieniędzy swoich $i$ cudzych, należy placić; gdzie bank nie może, pośle spótkę córkę; ryzyko jest statym elementem dziatalności gospodarczej, może przynosić straty, lecz również zyski nadzwyczajne; czasami warto coś sprzedać, zanim się jeszcze kupito.

Cieszę się, że mogłem się uczyć od Pana Profesora, asystować przy wykładach i wystąpieniach, wspólnie publikować i uczestniczyć w pracach zleconych. Zwłaszcza miło wspominam trzy epizody. 
Po pierwsze, asystowanie przy przygotowaniu wystąpienia Pana Profesora w 2014 r. nt. Unii bankowej w Europie (oprócz pracy merytorycznej opatrywaliśmy wówczas prezentację Pana Profesora pasującymi, czasami zabawnymi obiektami graficznymi).

Po drugie, wykonanie zlecenia Ministra Skarbu Państwa po wygranym ogólnokrajowym konkursie, na podstawie którego Wydział Zarządzania UW wraz z KPMG przeprowadził badanie i analizę procesów prywatyzacyjnych w ramach wykonywania planu prywatyzacji na lata 2008-2011. Wspólnie z Profesorem Górskim zrobiliśmy wówczas badanie ankietowe oceny procesu prywatyzacji w polskim środowisku naukowym na kierunkach ekonomia i zarządzanie, a największą trudnością było... pozyskanie wypełnionych kwestionariuszy. Lecz później, kiedy już udało się je zdobyć, opracowanie wyników i wyciągnięcie wniosków było czystą przyjemnością. Pomagali nam wówczas młodzi doktoranci, Profesora Górskiego i moi byli studenci - Patrycja Chodnicka i Piotr Jaworski, których później połączyło uczucie i związek małżeński. Do tej pory - już jako adiunkci - są oni pracownikami naszej Katedry.

Po trzecie, wspólny artykuł nt. realnych stóp zwrotu inwestorów krajowych i zagranicznych z inwestycji finansowych w Polsce w latach 1994-2005, później zaktualizowany o 2006 r. (pracowaliśmy przy nim we trzech: Pan Profesor Górski, doktor Radosław Winiarski i ja). Profesor Górski szefował i komenderował, tworzył metodykę, weryfikował obliczenia, dyskutował z nami, opisywał wyniki, my zaś z doktorem Radkiem Winiarskim dwoiliśmy się i troiliśmy, żeby pozyskać dane i wykonać obliczenia. Owocem była obszerna publikacja zawierająca m.in. wskaźnik Górskiego mierzący efektywność inwestycji.

Panie Profesorze, z okazji 70. urodzin życzę Panu Profesorowi zdrowia i wyzwań intelektualnych. Spokoju Panu Profesorowi nie życzę, bo Pan Profesor lubi działać. 70 lat to piękny jubileusz, który warto uczcić, ale żadna cezura. Zaraz trzeba brać się do roboty. Niech Pan Profesor pracuje, działa, szefuje Katedrze, wspiera swą mądrością Uniwersytet Warszawski. Ze swej strony deklaruję, że z dumą będę rozwijał Pana Profesora szkołę finansową - Szkołę Górskiego! 


\section{GRZEGORZ JĘDRZEJCZAK}

\section{Profesor Marian Górski w moich oczach...}

Po studiach ekonometrycznych na WNE i po krótkiej przygodzie pracy jako informatyk, w 1975 roku zostałem zatrudniony w zespole docenta Kazimierza Rycia w nowo tworzonym Instytucie, który miał w przyszłości stać się Wydziałem Zarządzania. W tym zespole najstarszym, chociaż ciągle magistrem, był Marian „Marek” Górski - przystojny, szczupły blondyn nałogowo palący papierosy i pijacy kawę.

Lata 70. XX wieku to ciekawy, choć zapomniany czas PRL, szczególnie w porównaniu z późniejszym okresem lat karnawału Solidarności i stanu wojennego. Początek lat 70., czas dorastania naszego pokolenia, to czas traumy Grudnia, ale też nadziei na unowocześnienie gospodarki „epoki Gierka”. W tej dekadzie, nie tylko napływa kapitał zachodni, lecz także zaczynają się eksperymenty z systemem zarządzania gospodarką narodową. To również czas odejścia od wulgarnej wersji marksistowskiej „ekonomii politycznej socjalizmu". Pojawia się możliwość uprawiania makroekonomii, szczególnie keynesizmu wyznaczającego wtedy mainstream zachodniej ekonomii. Pojawia sie też nieortodoksyjna propozycja Jánosa Kornaia z jej kluczowym pojęciem „ekonomii niedoboru”.

Marian z dużym powodzeniem wykorzystał swój porządny warsztat ekonometryczny dla wprowadzenia do nauczania bardziej sformalizowanej makroekonomii. Choć ciągle nie jestem pewien na ile ci biedni studenci nadążali za wykładem, niewątpliwie próby Górskiego wyznaczyły nowe standardy nauczania ekonomii nie tylko na Wydziale Zarządzania, ale chyba i w Polsce.

Nasza współpraca ewoluowała, a efekty tej współpracy dały, przynajmniej w mojej późniejszej karierze zawodowej, bardzo wiele. Współpracę tę nazwał bym „dyskursywną”.

Pierwszy jej etap to atmosfera naukowej dyskusji w zespole Profesora Rycia. Zespół spotykał się co tydzień na merytoryczną dyskusję pracy 
poszczególnych członków zespołu, jak również ciekawych rozwiązań dydaktycznych. Doktorat Górskiego był ważnym elementem tej dyskusji. Praktyka ta dzisiaj została niestety porzucona $\mathrm{z}$ wielka szkodą dla rozwoju zawodowego młodszych kolegów.

Drugi etap, to wynik decyzji o napisaniu wspólnej książki jako podstawy habilitacji. Ze względów formalnych poszczególne rozdziały trzeba było przypisać poszczególnym autorom, ale całość była wynikiem długich rozmów merytorycznych (choć nierzadko w „niemerytorycznych warunkach”).

Etap trzeci to początek transformacji. Los rzucil mnie do grona państwowych reformatorów systemu bankowego i rynku kapitałowego. Szybko zrozumiałem, że nawet najlepiej wymyślone reformy nie odniosą sukcesu bez ludzi zdolnych je wprowadzić w życie „tam na dole”. Dlatego też gdy państwowe jeszcze banki potrzebowały mocnych ludzi w radach nadzorczych, bez wahania zwróciłem się do, wtedy już Profesora, Górskiego o włączenie się w reformę konkretnych banków. W ten sposób przyczyniłem się zarówno do sukcesu reformy bankowej, jak i do pojawienia się wybitnego specjalisty od systemu finansowego.

Pragnę w tym miejscu zwrócić uwagę, że użyłem określenia „mocnych ludzi w radach nadzorczych" a nie "fachowców w radach nadzorczych”. Przyczyna jest prosta - fachowców po prostu nie było. Dla młodszych kolegów był to niepowtarzalny czas, nie tylko bowiem nie było fachowców z wiedzą zdobytą w praktyce, lecz także nie było języka analizy i zarządzania nowo powstałym systemem finansowym i trzeba go było tworzyć „w biegu”. Potwierdza to tezę, że „fachowości” można się nauczyć, konieczna jest jednak umiejętność profesjonalnej analizy, wypracowana nie tyle przez nawet najlepszą znajomość literatury przedmiotu, ile przez jej „przepracowanie” w dyskursywnej atmosferze zespołu. I tu koło się zamyka. 


\section{KRZYSZTOF KALICKI}

\section{Profesor Marian Górski w moich oczach...}

Pana Profesora Mariana Górskiego miałem przyjemność poznać dzięki profesorowi Grzegorzowi Jędrzejczakowi, z którym wspólnie pod koniec lat 80. napisał książkę pt.: Równowaga $i$ stabilność w gospodarce socjalistycznej opublikowaną przez PWN. Był to czas dużej aktywności naukowej naszego pokolenia, która wynikała z wątpliwości dotyczących dalszego rozwoju systemu, w którym wtedy żyliśmy. Mieliśmy świadomość - jako młodzi pracownicy nauki - że muszą zachodzić zmiany systemowe i wszyscy szukaliśmy inspiracji $\mathrm{w}$ mainstreamowych trendach współczesnej myśli ekonomicznej transponowanej na inny, nowy grunt. Sam w tym czasie pisałem o inflacji i gospodarce cienia $\mathrm{w}$ gospodarce centralnie planowanej. I tematyka, i czasy bardzo nas zbliżały naukowo oraz w podejmowaniu działan środowiska na rzecz reform, np. sektora bankowego, polityki pieniężnej, systemu kursowego, prywatyzacji banków, które ruszyły gwałtownie od momentu transformacji. Profesor szybko wyzwolił się z myślenia, że reformy mają być dokonywanie przez jakiś mechanizm ustrojowych konwergencji, co przewijało się w licznych wymianach z nim poglądów - nie tylko na forum prywatnym, lecz także publicznym.

Z Profesorem M. Górskim miałem okazję się spotykać na początku lat 90. na wielu seminariach, konferencjach naukowych i naradach dotyczących przekształceń sektora bankowego, analizy zmian makroekonomicznych w dziedzinie równowagi pieniężnej. Jego wysokiej klasy prace naukowe spełniały postulat wiązania nauki z praktyką i miały charakter aplikacyjny. Wywierał on szeroki i bezpośredni wpływ na transformującą się gospodarkę.

Nasze drogi krzyżowały się również w praktyce gospodarczej w czworokącie Ministerstwo Finansów wraz z Instytutem Finansów, Ministerstwo Skarbu, NBP i banków. Profesor M. Górski zasiadał wtedy w radzie nadzorczej pierwszego prywatyzowanego banku w ramach tzw. 9 Wielkopolskiego 
Banku Kredytowego S.A. - jako jej członek, a następnie przewodniczący Rady Banku 1991-2001. Już później miałem okazję go spotykać w sektorze bankowym, jako przewodniczącego Rady Nadzorczej Banku Zachodniego WBK S.A. Profesor znakomicie łączył swoją wiedzę teoretyczną z praktyką codzienną sektora bankowego, wdrażając wtedy programy restrukturyzacyjne i zmiany własnościowe, co wymagało wiele konsekwencji, dyscypliny i zaangażowania. Praca na rzecz sektora finansowego wiązała się również z odpowiedzialnością, którą bez wahania wziął na siebie. Nigdy nie unikał on jednak spraw trudnych, a dodatkowo prezentował, nieczęsto pojawiający się na uczelniach, instynkt decydenta gospodarczego stawiającego czoła nawet niecodziennym zdarzeniom, np. wtedy, gdy wystąpił sprowokowany fałszywą informacją run na bank lub gdy decydowano o składzie konsorcjum prywatyzacyjnego. On sam wie jak trudny i stresujący był to okres w życiu naszego pokolenia, ale nigdy nie unikał wzięcia na siebie odpowiedzialności.

$Z$ podziwem też patrzyłem na jego dalszą działalność naukową ukazująca, jak doświadczenia z praktyki rynków finansowych mogą być wykorzystywane w publikacjach naukowych i udostępniane dla celów dydaktycznych. Jego podręczniki do dzisiaj służą kolejnym pokoleniom studentów różnych uczelni. Wiemy doskonale jak trudno jest pogodzić liczne aktywności z praca naukową, ale to się Profesorowi M. Górskiemu udawało.

Miałem też okazję być świadkiem pryncypialności Profesora w odniesieniu do jednej z recenzowanych przez nas prac doktorskich, gdzie nieugięcie bronił swojego stanowiska.

Profesor M. Górski okazał się także utalentowanym organizatorem - jest znany z tego, że tworzył nowe instytucje - czy to gospodarczo-konsultingowe, czy też ważne instytucje środowiskowe - jak np. Polski Instytut Dyrektorów, z który miałem okazją współpracować. Ta inicjatywa była bardzo ważna nie tylko w sensie naukowym, lecz także jako think-tank formułujący wymagania etyczne i organizacyjne w odniesieniu do kadr kierowniczych polskiego biznesu.

Podsumowując, Profesor Marian Górski wywarł znaczący wpływ na moją percepcję teorii ekonomii i model pracownika łączącego naukę z praktyką. 


\section{RENATA KARKOWSKA}

\section{Renata dla Profesora Mariana Górskiego}

W moich wspomnieniach Profesor Marian Górski zawsze pozostanie przykładem szefa Katedry stabilnie stąpającego po ziemi w środowisku naukowym, które ze swojej definicji często wzbudza wiele wątpliwości i problemów.

Swoją przygodę na Uniwersytecie zaczęłam od studiów doktoranckich na Wydziale Zarządzania Uniwersytetu Warszawskiego, które rozpoczęłam w październiku 2001 roku. Jako doktorantka miałam obowiązek odbywania praktyki dydaktycznej, więc zgłosiłam się do Profesora M. Górskiego w prośbą o możliwość poprowadzenia ćwiczeń do wykładu „System finansowy gospodarki”. To było moje pierwsze spotkanie z Profesorem. Pamiętam, jak zapytał mnie, czym się interesuję i jakie jest moje doświadczenie zawodowe. Pozytywnie odebrał, że oprócz studiów podejmowałam również pracę w bankowości. Zawsze uważał to za cenny atut wykładowcy, co wynikało zapewne w praktyki jaką osobiście uprawiał. Na początku dostałam dwie grupy studentów, w kolejnych latach było ich zdecydowanie więcej. Cztery lata studiów doktoranckich przebiegły bardzo szybko, 14 listopada 2005 roku podeszłam do obrony pracy doktorskiej, której tytuł brzmiał Determinanty rozwoju rynku kredytowych instrumentów pochodnych. Perspektywy powstania rynku w Polsce. Profesor M. Górski był moim recenzentem. Pamiętam, że na obronie zadał mi pytanie o lokalizację ryzyka $\mathrm{w}$ globalnym systemie finansowym. Niewiele wtedy odpowiedziałam, ale tym samym Profesor stał się dla mnie inspiratorem do dalszych dociekań jako naukowca. Po latach, to pytanie stało się przyczynkiem do rozwijania moich badań naukowych. A rynek finansowy nadal nie jest na tyle przejrzysty, żeby odpowiedzieć na nurtujące pytanie, gdzie ostatecznie jest ulokowane ryzyko transferowane za pomocą instrumentów pochodnych? Po doktoracie (a dokładnie od października 2006 roku) Profesor M. Górski powierzył mi prowadzenie wykładu 
z „Bankowości” dla grupy studentów w Płocku. Były to weekendowe wyjazdy, które mimo uciążliwości 2 godzinnej wyprawy, miały dla mnie istotne znaczenie dydaktyczne. W końcu był to pierwszy wykład, jaki prowadziłam jako młoda Pani doktor.

W kolejnych latach razem uczestniczyliśmy w projekcie Szkoły Giełdowej na Wydziale Zarządzania, w którym Profesor wykładał „Podstawy funkcjonowania giełdy". Nie było to zadanie łatwe, tym bardziej że uczestnicy stawiali sobie ambitny cel „zbicia fortuny” na warszawskim parkiecie już po 15 godzinach teorii na temat rynku kapitałowego. Komu udało się to osiągnąć, tego chyba nikt nie weryfikował?

Zakład bankowości i rynków finansowych, w jakim rozpoczęłam pracę, składał się w większości z młodych osób, których w sumie łączyły podobne zainteresowania związane z rozwojem młodej gospodarki rynkowej w Polsce. Profesor M. Górski bardzo wszystkich mobilizował i jednoczył jako grupę. W czerwcu 2006 roku (po egzaminach) zaprosił nas na piknik do swojego domu poza miastem. Byliśmy tam wspólnie z Małgosią Mijal, Radkiem Winiarskim i Jakubem Górką. Wspólnie piekliśmy kiełbaski, paprykę i chleb z masłem czosnkowym. Po obfitej uczcie Profesor z dumą pokazywał nam zielony warzywniak i rabaty kwiatów, które były efektem pielęgnacji Państwa Górskich. Widać, że nie tylko finanse są Jego domeną, ale po mistrzowsku realizuje się również $\mathrm{w}$ innych dziedzinach. Jednak dusza profesorska nie opuszcza Go nawet na łonie przyrody... Otóż w pewnym momencie Profesor zaczął żartować i sprawdzać, czy aby na pewno znamy się na botanice, wypytując o nazwy poszczególnych roślin?? Pamiętam, że na mnie padło pytanie o bób. Na szczęście egzamin zdałam POZYTYWNIE. Przyjemnie było się spotkać i wspólnie żartować do późnych godzin wieczornych...

W roku 2009 Profesor M. Górski został Kierownikiem Katedry Systemów Finansowych Gospodarki, która po dziś dzień łączy dwa zakłady: Bankowości i Rynków Pieniężnych, oraz Ubezpieczeń i Rynków Kapitałowych. Z racji swoich zainteresowań, dotyczących ryzyka finansowego znalazłam się w strukturach tego drugiego. Trzeba podkreślić, że Profesor zgromadził w Katedrze ludzi przedsiębiorczych, którzy mają aspiracje rozwijać się naukowo i profesjonalnie, a silna pozycja dydaktyczna i badawcza Katedry na Wydziale Zarządzania jest na pewno zasługa jej szefa. Profesor zawsze dba o dobry wizerunek Wydziału i rozpoznawalność pracowników jego Katedry, od wielu lat zachęcając nas do aktywnego uczestnictwa w konferencjach naukowych.

W końcu Profesor to znakomity dydaktyk. Spod jego pióra wyszła bardzo dobra książka pt. Rynkowy system finansowy, dzięki której swoją wiedzę na temat finansów mogą poszerzać rzesze studentów uczelni ekonomicznych. 
Zapoznanie się z jej treściami stanowi solidną podstawę do poznania skomplikowanej architektury rynku finansowego.

Profesor Marian Górski pod płaszczem poważnych tematów finansowych, jakimi się zajmuje od lat, kryje dużo sympatii i zrozumienia dla innych, czego wyrazy mogłam osobiście doświadczyć podczas 17-letniej współpracy na Wydziale Zarządzania.

W rocznicę Jego 70. urodzin pragnę mu podziękować, oraz życzyć zdrowia i pogody ducha na kolejne lata! 


\section{MARCIN KOBUS}

\section{Profesor Marian Górski w moich oczach...}

18 listopada 2008 roku to najbardziej stresujący dzień w moim życiu. To w tym dniu miało się okazać czy 3 lata pracy nad rozprawą doktorską pt. Produkty strukturyzowane na rynku finansowym w Polsce pod kierunkiem Profesora Mariana Górskiego zostaną docenione przez szacowne gremium profesorów. Recenzje prof. Krzysztofa Jajugi i prof. Andrzeja Sopoćki dawały nadzieję, że pracę uda się obronić. Pamiętam tamte słowa Profesora: - najważniejsze to się nie stresować $i$ precyzyjnie odpowiadać na zadawane pytania. Tak robiłem i się udało.

W tym samym miesiącu rozpoczął działalność nowy bank, który w strategii nie bał się stawiać na innowacyjne rozwiązania inwestycyjne dające klientom szansę na zysk powyżej tradycyjnych lokat przy ograniczonym ryzyku. I właśnie w ten sposób, jako świeżo upieczony doktor, zacząłem wdrażać teorię w praktyce.

Rozprawa doktorska poświęcona została tematyce instrumentów finansowych określanych jako produkty strukturyzowane. Produkty strukturyzowane od lat siedemdziesiątych ubiegłego wieku są dostępne na rozwiniętych rynkach finansowych, jednak ich definicja na dzień obrony doktoratu nie była jednolita i precyzyjna. Dzięki współpracy z Profesorem Górskim udało się nam wypracować definicję tych instrumentów:

Produkty strukturyzowane to instrumenty finansowe kierowane do inwestorów indywidualnych, instytucjonalnych oraz instytucji finansowych poprzez inne podmioty finansowe w celu zaspokojenia potrzeb inwestycyjnych, spekulacyjnych $i$ hedgingowych lub w celu dalszej dystrybucji. Dzięki uniwersalnej i elastycznej w modelowaniu konstrukcji sktadającej się z kombinacji instrumentów finansowych z pewnym $z$ góry określonym przeptywem pieniężnym $i$ derywatów na instrumenty bazowe o podwyższonym dochodzie i ryzyku lub samych derywatów produkty strukturyzowane potrafia zapewnić w okresie trwania inwestycji róż- 
nego rodzaju profil wyptaty, przy określonej ochronie zainwestowanego kapitatu. Różnorodna forma prawna, jaka produkty moga przyjmować w obrocie, oraz dowolność geograficzna i rynkowa inwestycji zapewnia nabywcom tych produktów wiele korzyści: podatkowych, finansowych i inwestycyjnych. Definicję tę do dnia dzisiejszego wykorzystujemy podczas szkoleń nowych pracowników banku.

W rozprawie doktorskiej postawiona została następująca teza główna: Makroekonomiczne uwarunkowania oraz potrzeby gospodarstw domowych w Polsce sprzyjaja rozwojowi rynku produktów strukturyzowanych. Udało się ją udowodnić na wysokim poziomie uniwersyteckim, ale również udało się ją udowodnić w praktycznym zastosowaniu podczas pracy w banku. Od czasu obrony wprowadziłem na rynek 450 produktów strukturyzowanych na łączny wolumen $10 \mathrm{mld}$ PLN, z których skorzystało 65 tysięcy klientów. Po tych 10 latach mogę z całą pewnością stwierdzić, że makroekonomiczne uwarunkowania oraz potrzeby gospodarstw domowych w Polsce sprzyjały rozwojowi produktów strukturyzowanych, za co Promotorowi i najlepszemu Mentorowi Profesorowi Marianowi Górskiemu bardzo serdecznie dziękuję. 


\section{MONIKA KOSTERA}

\section{O zarządzaniu i kontekście - $i$ dlaczego to jest wazine}

Prof. Marian Górski i ja zasadniczo różnimy się zainteresowaniami naukowymi, podejściami badawczymi i obszarem badań. Jednak coś nas łączy, coś bardzo ważnego, a nawet fundamentalnego. Wiele lat temu rozmawialiśmy o naszych badaniach i wówczas Profesor powiedział mnie więcej tak: - bardzo ciekawe jest to, w jaki sposób osadzasz swoje teorie zarządzania w szerszym kontekście otoczenia $i$ bistorii. Zrobiło mi się niezwykle miło i pomyślałam sobie, że uniwersytecki Wydział Zarządzania może być jednym z niewielu miejsc, gdzie w nieprawdopodobnie ostatnio sfragmentaryzowanej nauce, można znaleźć okazje nie tylko koleżeńskie, lecz także instytucjonalne do takiego budowania mostów. Bardzo lubię budować poznawcze mosty i mam wrażenie, że Profesor Górski także ma do tego serce. Dlatego postanowiłam ten krótki tekst dla Niego poświęcić mostom takim, jakie wtedy powiedział, że wydają mu się interesujące - opowiem o moich badaniach zarządzania okresu transformacji w kontekście historii, poszukiwań i inspiracji naukowych i, szerzej, w duchu interdyscyplinarności. Będzie to tekst bez naukowych powołan i bez bibliografii (choć z kilkoma nazwiskami) - wiemy doskonale, że stoimy na barkach gigantów i znamy ich imiona i teksty. Nie chodzi tutaj o tworzenie naukowego przekazu i argumentu, ale o opowiedzenie czegoś, co, mam nadzieję, sprawi Profesorowi podobną radość, co nasza rozmowa przed laty, gdy stwierdziliśmy oboje, że nauki o zarządzaniu mają sens, bo łączą ludzi, podejścia i dyscypliny badawcze. To stara, dobra misja nauki w ogóle - poznawać, dążyć do prawdy, poszukiwać złożonych, skomplikowanych odpowiedzi, zadawać pytania. Po to zostałam naukowcem; myślę, że pewnie po to też został naukowcem Profesor Górski. A więc łączy nas to, co najważniejsze, co sprawia, że niezależnie od różnic między nami, rozmowa ubogaca, ma sens. 
Na początku lat 90. XX wieku prowadziłam badania wśród polskich dyrektorów. Najpierw była to ankieta i wywiady, później etnografia, gdy dowiedziałam się o tej metodzie z książki Barbary Czarniawskiej pt. Exploring Complex Organizations, a potem nauczyłam od antropologa Richarda Rottenburga jej stosowania. Myślałam, że będzie to badanie wśród osób o usposobieniu raczej biurokratycznym, bez szczególnego zapału do zarządzania. Tymczasem spotkałam ludzi z ogromnym doświadczeniem menedżerskim, pełnych energii i pomysłów, lecz całkiem odmienną perspektywą, niż zachodni menedżerowie, których znałam z książek i wcześniejszych kontaktów, praktyk studenckich z czasów szwedzkich studiów i badań do doktoratu. Prosiłam ich, by mi opowiedzieli o przyszłości, ale oni nie chcieli. Zamiast tego opowiadali o przeszłości. Profesor Barbara Czarniawska poradziła mi, by zrobić porządne badania etnograficzne i słuchać tego, co oni chcą mi mówić. Tak też zaczęłam robić. Zaprosiłam na kawałek drogi wówczas studenta, Maćka Wichę, bo smutno jest podróżować samemu, a on interesował się teatrem, Ervingiem Goffmanem i zarządzaniem w PRL. Wyszła opowieść o różnych rolach, jakie grali polscy szefowie sprzed 1989 roku, od najbardziej walecznego Aktywisty, poprzez zdyscyplinowanego Biurokratę, do ulubionej przez polskich szefów roli z lat Gierkowskich, którą nazwaliśmy Dygnitarz. Potem przyszedł schyłek i nie było już tak pięknie ani ciekawie być kierownikiem przedsiębiorstwa. Właściwie kierownicy wtedy nie zarządzali, bo ich sprawczość była mocno ograniczona - system padał, był niesterowny. Wiele firm zostało przejętych przez osoby bez doświadczenia z zarządzania organizacja gospodarczą. Nazwaliśmy szefa z tego okresu Zmiennikiem.

„Moi” szefowie zaczęli mi też opowiadać o teraźniejszości, choć na ogół $\mathrm{z}$ odniesieniami do przeszłości. Przeszłość była stale żywa $\mathrm{w}$ ich świecie, nawet taka przeszłość, której niektórzy z nich nie mogli pamiętać jako aktywni kierownicy (lata 50.), a więc także historia bardziej odległa - duchy zarządzania. Mówili o swoich różnych postawach i pomysłach na to, jak zarządzać i po co, o tym jak chcą wykorzystać swoje doświadczenie (i duchy) do tego, by robić nowe rzeczy. Było jasne, że istnieje wiele strategii i pomysłów na transformację, nie ma „jedynie słusznej drogi”, a już na pewno nie było tak, że nie istniały alternatywy.

Napisałam książkę o moich etnograficznych badaniach polskich szefów $\mathrm{z}$ wczesnych lat 90 . XX wieku, książkę, której nikt nie przeczytał, pewnie z powodu „modnego” tytułu, jaki nadało jej wydawnictwo, Postmodernizm w zarzadzaniu (zgoda, zaproponowany przeze mnie tytuł nie był bardziej rynkowy, był też odrobinkę pretensjonalny, ale przynajmniej odpowiadał treści - Metamorfozy polskiego przedsiębiorstwa). Z perspektywy czasu jest 
to książka o tym, że inne zarządzanie jest możliwe. Jeśli popatrzeć wstecz z punktu widzenia idei czasu mesjańskiego Waltera Benjamina, czyli czasu poza historią pisaną przez zwycięzców, to $\mathrm{w}$ tym mesjańskim czasie kryją się otwarcia w inne światy poprzez momenty doświadczane. Okazuje się, że nie musimy kurczowo trzymać się tak niepodzielnie obecnie panującej wersji ekonomii i zarządzania. Możliwości odnowy, szanse na znalezienie innych dróg, istnieją nie tylko za granicą (gdzie wcale nie jest tak cudownie, jak się wielu Polakom wydaje), w nieodgadnionych „mózgach wielkich” lub cudach, na które wiele osób zdaje się czekać, ale w nas, między nami, w naszych własnych doświadczeniach. To tym właśnie jest wyobraźnia organizacyjna umiejętnością przemieszczania sie poza tym, co Benjamin nazywał czasem pustym, liniowym.

Polscy szefowie z początku lat $90 . \mathrm{XX}$ wieku mieli wiele pomysłów, nadziei i doświadczeń, na których chcieli budować nowe wzorce zarządzania. O wiele mniej różnorodny był świat kobiet-menedżerów. Wywiady etnograficzne z szefowymi pokazały ogromną presję, jaka była na nie wywierana przez oczekiwania społeczne skierowane $\mathrm{z}$ różnych stron i dążące do narzucenia bardzo tradycyjnej roli kobiety, nie zawierającej przestrzeni na interpretacje ani nawet bardzo podsatwową różnorodnośc. Kobiety wykorzystywały strategię, która do dziś jest wśród polskich szefowych często spotykana - traktowania swojej roli profesjonalnej jako tarczy, za którą mogą się schować. Jest to strategia defensywna i zindywidualizowana, bardzo mało sprawcza i nietwórcza - tarcza wymierzona jest także przeciwko innym kobietom i oparta jest głównie na randze.

W latach 90., zwłaszcza w pierwszej połowie, przyjeżdżali do Polski liczni konsultanci i doradcy z Zachodu. Organizowane były szkolenia i seminaria, podczas których głosili po swojemu „zasady zarządzania” bez żadnego związku z kontekstem, wiedzą czy doświadczeniem słuchaczy, „zasady” całkowicie niesystemowe, bez dalekosiężnej wizji, bez metody. Polscy szefowie, w tym mój teren badawczy, podśmiewali się z tego, co było tam wykładane, ale nie protestowali ani nie zabierali głosu. Byli przekonani, że to po prostu „jeszcze jedna szopka”, jakich już wiele w życiu mieli okazję spotkać. Myśleli, że trzeba to cierpliwie przetrzymać, robić swoje - w dłuższym okresie ideologie opadną, a wyniki pracy pozostaną. Nikt z nas wówczas nie przypuszczał, że ogłaszana wersja świata okaże się aż tak bardzo trwała, że nie jest to kolejna „szopka”, lecz coś znacznie więcej.

Dawno, dawno temu, na początku lat 80 . XX wieku, gdy studiowałam zarządzanie w Lund, w ogóle nie uczyliśmy się o małym biznesie, bo to nie byto zarządzanie. Mały biznes miał tendencję do kompromisów na jakości, 
wykorzystywania pracowników, nierespektowania związków zawodowych (głównego poważnego partnera dla zarządzania) i, powiedzmy sobie szczerze, nie posiadał charakterystycznej dla „prawdziwych firm” hojności. Zarządzanie to były wówczas wielkie wizje, rozmach, system i metoda. Oszczędzać na kliencie? Nie do pomyślenia, już w średnim okresie takie działanie obróci się przeciwko firmie. Oszczędzać na pracownikach? Kompletny nonsens, przecież inwestycje w ludzi to podstawa wszelkiego naukowego podejścia do zarządzania. Muszę powiedzieć, że moi rozmówcy, PRL-owscy szefowie, też wierzyli w zarządzanie i system, w to, że przyszłość to wizja i metoda. Może nawet wierzyli w to bardziej, niż szefowie zachodni i nasi wykładowcy $\mathrm{z}$ Lund?

Jakiś czas temu wysłuchałam wykładu historyka twierdzącego, że Rzym upadł, ponieważ ludzie przestali kierować się Rzymem, Rzym przestał być dla nich sensowną wartością. Kontekst - praw ekonomii: systemów finansowych, cykli koniunkturalnych, polityk pieniężnych, równowagi gospodarczej - ale też wartości, jest o wiele ważniejszy, niż wielu osobom się wydaje. Szacunek i uznanie należą się tym, którzy widzą prawa i wzorce, ale też tym, którzy mają pryncypia, dla których wartości są sensowne i realne.

To nieprawda, że człowieka najlepiej poznaje się w złych czasach, bo wtedy każda osoba redukuje się do jednego spójnego wątku. Nie, człowieka można poznać tylko w dobrych czasach, kiedy każdy ma wiele stron, wiele pragnień, marzeń, snów. Zarządzanie też jest czymś bardziej szlachetnym w czasach dobrych, gdy ma wiele stron. Jestem wdzięczna za rozmowy, które umożliwiały i umożliwiają mi nadal poznawanie ich. Jestem wdzięczna takim naukowcom jak Profesor Marian Górski, który lubi budować naukowe i poznawcze mosty. 


\section{EWA KRAKOWIŃSKA}

\section{Kilka zdań od bytej studentki}

Pan Profesor Marian Górski obchodzi w tym roku swój Jubileusz, który pozwala Jego przyjaciołom i uczniom podzielić się wspomnieniami związanymi ze współpracą naukową, dydaktyczną, a także Nim jako kolegą i przyjacielem.

W roku akademickim 1972/1973 rozpoczęłam studia w nowo powstałym na Uniwersytecie Warszawskim Instytucie Zarządzania. Choć przyszli studenci niewiele wiedzieli o tej dyscyplinie naukowej, konkurencja na egzaminie wstępnym była duża. Na pierwszy rok studiów przyjęto około stu studentów. Jak się okazało w październiku, budynek przy ulicy Długiej 44/50 (obecnie WNE) nie został wyremontowany na czas, odbywały się zatem tylko wykłady w wynajętych salach na Krakowskim Przedmieściu, Pałacu Kultury i Nauki oraz w Szkole Podstawowej przy ulicy Żytniej. W listopadzie mogliśmy już zdobywać wiedzę w części wygospodarowanych sal przy ulicy Długiej razem ze studentami WNE.

Pierwsze zajęcia, ćwiczenia z „Podstaw matematyki”, dla wielu z nas humanistów - okazały się być przedmiotem trudnym. Dwudziestoosobowa grupa ćwiczeniowa w napięciu oczekiwała na osobę prowadzącą zajęcia, do sali wszedł młody, uśmiechnięty mgr Marian Górski, popatrzył po naszych twarzach i, nim doszedł do swojego biurka, podyktował nam pierwsze zadanie $\mathrm{z}$ rachunku prawdopodobieństwa. Poprosiliśmy Pana magistra o krótkie przypomnienie materiału, co uczynił dość szybko. Dla studentów - zbyt szybko, nikt bowiem nie mógł rozwiązać zadania. Atmosfera na sali stała się napięta, my nie umieliśmy rozwiązać zadania, a prowadzący zajęcia nie bardzo wiedział co z tym „fantem” zrobić? W końcu jeden z kolegów poprosił, abyśmy wspólnie rozwiązali zadanie i zaproponował, że na następne zajęcia przygotujemy się z rachunku prawdopodobieństwa i zrobimy więcej zadań Po skończonych tego dnia zajęciach długo dyskutowaliśmy, jak ułożyć współpracę z Panem Magistrem. Kolejne zajęcia już nie wzbudzały takiej grozy, 
pierwsze „lody” zostały przełamane. Jak się potem okazało, ulubionymi zadaniami Pana Magistra były macierze, które odwracał i liczył w pamięci, gdy pochyleni nad zadaniem usiłowaliśmy zrozumieć i nadążyć za prowadzącym zajęcia. Nie było to łatwe, można było bowiem zauważyć, jak spogląda za okno dość zniecierpliwiony naszą powolnością. Nic też dziwnego, że w wiosenny ciepły dzień, grupa postanowiła zrobić sobie „Dzień wagarowicza” pomysł głupi, ale wszyscy mu się poddaliśmy.

Na kolejnych zajęciach Pan Magister słowem nie wspomniał o naszym wyczynie, za to poprosił o wyjęcie kartek i... pisaliśmy z nieprzerobionego materiału „kartkówkę”. Po jej zebraniu poinformował nas, że tak będzie do końca semestru. No cóż, kara była sroga, ale nikt nie miał pretensji, mogliśmy tylko wyobrazić sobie minę Pana Magistra, gdy zobaczył pustą salę. Po latach moge powiedzieć, że było to idealne rozwiązanie, zmusiło nas to do nauki, a w konsekwencji - do zdania bez problemu egzaminu. Na marginesie, do dzisiaj podziwiam ogrom pracy wykonanej przez prowadzącego zajęcia (sprawdzać co tydzień tyle prac!).

Egzamin z „Podstaw matematyki” był pisemny, a następnie, po jego zaliczeniu ustny dla osób, które chciały poprawić ocenę. Ja po zaliczeniu na ocenę dostateczną egzaminu pisemnego, nie przystąpiłam do egzaminu ustnego, co, jak mi powiedzieli koledzy z mojej grupy, wywołało niezadowolenie Pana Magistra.

Po zakończeniu sesji moja grupa udała się do Pana Magistra, aby podziękować za przygotowanie do egzaminu i za to, że nawet na egzaminie ustnym był obecny i wpierał koleżanki i kolegów, gdy odpowiadali, zadając bardzo pomagające $\mathrm{w}$ odpowiedziach pytania.

$\mathrm{Na}$ trzecim roku studiów byliśmy już doświadczonymi studentami, ćwiczenia z „Planowania i polityki społeczno-gospodarczej” prowadził Pan Magister Marian Górski. Zajęcia z tego przedmiotu odbywały się w piątkowe popołudnia. Trzeba przyznać, że to niefortunny czas na analizowanie tak złożonych problemów gospodarczych, tym bardziej że prowadzący zajęcia tłumaczył mocno sformalizowane modele ekonometryczne. Po latach pamiętam tylko czółenko planistyczne, a dlaczego?

Moja grupa ćwiczeniowa postanowiła zorganizować kolejne spotkanie integracyjne i po sali krążyła kartka, związana z optymalizacją zakupów na ten wieczór. Pan Magister, trochę poirytowany naszą biernością na zajęciach, zabrał koleżance kartkę i widać było, że jej treść bardzo Go zdenerwowała. Rozwiązanie tej trudnej sytuacji nastąpiło bardzo szybko. Pan Magister postanowił, że wspólnie za pomocą czółenka planistycznego rozwiążemy problem. Zabawy było dużo w przeprowadzanej analizie, ale dzięki temu zagadnienie pamiętam do dzisiaj, a minęło sporo czasu. 
Dzisiaj, gdy sięgam do zakamarków swej pamięci przypominam sobie, jak poważnie Pan Profesor Marian Górski podchodził do prowadzonych zajęć. Może nie za często się do studentów uśmiechał, ale budził naszą sympatię, ponieważ sprawiedliwie nas oceniał i bardzo starał się pomóc w opanowaniu omawianych zagadnień.

$\mathrm{Na}$ moim roku studiów jeden z kolegów brał udział w turniejach brydżowych i postanowił nauczyć nas gry w brydża. W każdej wolnej chwili na korytarzach graliśmy w brydża (w tym czasie było to „zmorą” Instytutu). Zdarzało się, że przechodząc obok stolika brydżowego, Magister Marian Górski na chwilę się zatrzymywał i czasami nawet podpowiadał zagrywkę, budząc sympatię grających.

Po ukończeniu studiów rozpoczęłam pracę w Instytucie Organizacji i Kierowania UW i PAN (nastąpiła zmiana nazwy Instytutu Zarządzania) w Zakładzie Konsumpcji i Rynku, którego kierownikiem był Profesor Kazimierz Ryć i w którym był zatrudniony Doktor Marian Górski.

$\mathrm{Na}$ wyjazdowej konferencji Instytutu pierwszą uwagą, jaką usłyszałam od Doktora Mariana Górskiego, było stwierdzenie, że tak szczupła osoba nie powinna zajmować się konsumpcją, było to bardzo miłe i jednocześnie pozwoliło mi na pokonanie tremy związanej z naszymi nowymi relacjami zawodowymi.

Początki mojej pracy dydaktycznej były dla mnie bardzo stresujące (zajęcia z „Ekonomii”) i wtedy Pan Profesor bardzo mi pomógł. W wolnych chwilach przychodził na moje zajęcia, nie była to hospitacja zajęć, obserwował moje poczynania, następnie zaś dzielił się swoimi uwagami, a były one dla mnie bardzo cenne. Dzisiaj mogę powiedzieć Est rerum omnium magister usus (nauczycielem wszystkich rzeczy jest doświadczenie).

Kolejne lata pracy w Instytucie, a potem na Wydziale Zarządzania, pozwoliły mi poznać Pana Profesora jako osobę o dużym poczuciu humoru, pełną energii i pasji naukowej. Pan Profesor zawsze był i jest związany z praktyką gospodarczą, stąd w swojej pracy naukowej i dydaktycznej korzysta ze zdobytego doświadczenia. Wypromował ponad sto prac magisterskich oraz kilka prac doktorskich, dzięki czemu absolwenci Wydziału podejmują pracę na rynku kapitałowym lub pośrednio wspomagają rozwój rynku finansowego.

Żywię głębokie przekonanie, że nasz Dostojny Jubilat nadal będzie wydawał kolejne książki z zakresu bankowości i rynków finansowych, promował kolejnych doktorów i magistrów oraz podejmował nowe wyzwania naukowe i dydaktyczne. Życzę mu tego z całego serca. 


\section{ADAM PARFINIEWICZ}

\section{Z okazji 70. urodzin Profesora Mariana Górskiego}

Za dwa lata, w 2020 r., minie trzydzieści lat od mojego pierwszego spotkania z Panem Profesorem Marianem Górskim. W październiku 1990 r. przyszedłem na pierwszy prowadzony przez Niego wykład z makroekonomii. Pisząc to wspomnienie, musiałem szukać $\mathrm{w}$ pamięci zdarzeń $\mathrm{i}$ impresji z tych i kolejnych lat. Muszę przyznać, że z perspektywy czasu widać to pierwsze spotkanie jako prawdziwy „efekt skrzydeł motyla” - jak duży wpływ na moje dalsze życie zawodowe miały drobne z pozoru szczegóły...

Trzeba pamiętać, że przed 1989 rokiem decyzje o wyborze studiów miały często charakter dość przypadkowy. Pierwsze reformy miały już wprawdzie miejsce, ale polska gospodarka wciąż w bardzo niewielkim stopniu przypominała ekosystem, w którym żyjemy dziś. W gospodarce przed transformacją 1989 r. zarządzanie było wprawdzie dyscypliną ważną, ale nie jawiło się jako ekscytujące wyzwanie. W tym kontekście mój wybór kierunku studiów nie był efektem szczególnych przemyśleń, prawdę mówiąc decyzję o złożeniu dokumentów na Zarządzanie podjąłem niejako dla towarzystwa, po prostu dołączyłem do moich trzech kolegów z klasy. Piszę o tym dlatego, że na to, jak dalej potoczyło się moje życie zawodowe, wpływ miało właśnie spotkanie z wykładowcami na Wydziale Zarządzania, a w największym stopniu właśnie z Profesorem Górskim.

Po tylu latach niewiele pamiętam $\mathrm{z}$ treści wykładów $\mathrm{z}$ makroekonomii ani z następujących po nich w kolejnym roku wykładach z pieniądza i bankowości, przykryły je kolejne pokłady lektur, a w jeszcze większym stopniu praktyczne doświadczenia z tych dyscyplin. Bardzo dobrze natomiast pamiętam do dziśs wrażenia, jakie z tych pierwszych wykładów wyniosłem.

Po pierwsze, z perspektywy lat widzę, jak profesjonalnie Profesor podchodził do pracy dydaktycznej. Nie wiem jak dzisiaj wygląda etos pracy kadry naukowej, jednak na początku lat dziewięćdziesiątych utrzymywanie przez 
wykładowców nauczania na szczycie listy ich priorytetów nie zawsze było oczywiste. Trzeba pamiętać, że był to okres, kiedy błyskawicznie, praktycznie z dnia na dzień zmieniała się Polska i wraz z tymi zmianami - a właściwie poprzedzając je - zmieniał się też Wydział Zarządzania. Wielu wykładowców pracowało zawodowo w strukturach rządowych lub jako menedżerowie w jeszcze państwowych, sprywatyzowanych lub niedawno założonych prywatnych firmach. Te pozauczelniane aktywności często wypierały działalność dydaktyczną, wydawało się to wtedy dość naturalne, jednak z perspektywy lat bardzo doceniam fakt, że nigdy nie dało się tego odczuć z przypadku Profesora Mariana Górskiego. Fakt, że nie opuszczał wykładów i przychodził na nie zawsze przygotowany miał znaczenie na dwóch poziomach: oczywiście pomagał przyswoić wiedzę $\mathrm{w}$ uporządkowany sposób i przygotować się do egzaminu, ale również - a w zasadzie przede wszystkim - uczył poważnego traktowania swojej pracy. Myślę, że to jedna z najważniejszych wartości, jakie ja i moi koledzy wynieśliśmy ze studiów!

Po drugie - bardzo ważny był sam sposób prowadzenia wykładów. Profesor Marian Górski należał do wykładowców przekazujących wiedzę w sposób bardzo uporządkowany, robienie notatek z tych wykładów było wręcz przyjemnością. Do tego dochodził spokojny, wyważony sposób prezentacji, czytelna artykulacja i zawsze poprawny polski język - wszystko to miało ogromne znaczenie, bo w ten sposób jednocześnie przyswajaliśmy wiedzę z przedmiotów, które Profesor wykładał, uczyliśmy się porządkować tę wiedzę, a także przygotowaliśmy się do roli osób przekazujących informacje. Ponownie, to jedna z najważniejszych rzeczy, jakich powinniśmy się podczas studiów na Wydziale Zarządzania nauczyć, ponieważ moim zdaniem porządkowanie i formułowanie przekazu jest najważniejszą umiejętnością menedżerów. Z tej perspektywy uczestnictwo w wykładach Profesora Górskiego należało do najważniejszych doświadczeń formujących nas jako przyszłych liderów organizacji.

Pisząc o najwyższej kulturze pracy jako wykładowcy i wyniesionych z kontaktów z Profesorem lekcji profesjonalnego zachowania w naszym życiu zawodowym, nie można nie napisać o tym, że podczas prowadzenia wykładów Profesor po prostu zawsze dobrze wyglądał. I znowu, może się to wydawać efektem ubocznym, ale na początku lat dziewięćdziesiątych fakt, że Profesor Górski przychodził na wykłady w dobrze skrojonej marynarce, że skórzaną teczką i w wypastowanych butach nie był oczywisty. Fakt, że to zapamiętałem świadczy o tym, że na pewno nie było to w tych czasach standardem, a dzięki Profesorowi mieliśmy nie tylko wiedzę potrzebną do podjęcia pracy, ale też wizerunkowy punkt odniesienia, bardzo pomocny, gdy 
staraliśmy się jak najlepiej zaprezentować naszym pierwszym pracodawcom na początku pracy zawodowej.

Wszystkie te elementy zdecydowały, że gdy przyszło do wyboru promotora pracy magisterskiej, poprosiłem o przyjęcie tej roli właśnie Profesora Górskiego. Wspominam ten czas jako okres intensywny, ale też bardzo jestem Profesorowi wdzięczny za pomoc i wskazówki przy pisaniu pracy. Temat, który wybrałem był związany z pracą, którą już w tym czasie podjąłem (równolegle do studiów), jednak to właśnie współpracy z promotorem zawdzięczam fakt, że jej przygotowanie było wręcz przyjemnością. Podobnie wspominam sam egzamin magisterski, który mimo dużego ciężaru odpowiedzialności przeszedł sprawnie i w zasadzie bezstresowo, właśnie dzięki wskazówkom i wsparciu Profesora.

Po skończeniu studiów z entuzjazmem skorzystałem ze złożonej przez Profesora Mariana Górskiego propozycji poprowadzenia ćwiczeń z pieniądza i bankowości, na studiach zaocznych. Byłem zaszczycony, mogąc prowadzić te zajęcia jeszcze przez dwa lata po zdaniu mojego egzaminu magisterskiego, dawało mi to też możliwość utrzymania kontaktu z Profesorem. Poza tym było to dla mnie kolejne, bardzo cenne doświadczenie - musiałem płynnie zmienić strony i wejść w rolę wykładowcy. Bez cienia wątpliwości mogę powiedzieć, że ten czas był jednym z najważniejszych elementów mojej formacji zawodowej, procentującym praktycznie do dzisiaj.

Pisząc tych kilka refleksji trudno mi było wyrazić, jak bardzo jestem Profesorowi Górskiemu wdzięczny za pomoc we wprowadzeniu mnie w dorosłe życie zawodowe. $Z$ całą pewnością mogę jednak powiedzieć, że był jedną z najważniejszych osób, jakie spotkałem na swojej drodze zawodowej, tym ważniejszą, że miałem szczęście na Niego trafić na samym początku. I mimo że od wielu lat nie mamy już bezpośredniego kontaktu, to staram się dawać Mu znać, że nadal jest dla mnie ważną osobą, wysyłając co roku życzenia świąteczne.

Teraz, z okazji 70. urodzin, chciałbym Panu, panie Profesorze, życzyć, żeby zawsze towarzyszyło Panu poczucie, jak wiele Pan znaczył i nadal znaczy dla mnie, osób z mojego pokolenia i wszystkich, których Pan formował przed nami i po nas. Dziękuję! 


\section{LESZEK PAWEOWICZ}

\section{Profesor Marian Górski w moich oczach...}

Profesora Mariana Górskiego miałem zaszczyt poznać na początku lat dziewięćdziesiątych. Zajmował się wówczas zagadnieniami z obszaru transformacji gospodarczej i polityki stabilizacyjnej. Napisał na ten temat kilka ciekawych prac studialnych, w czasie kiedy wraz z Kolegami liberałami z Gdańska (Januszem Lewandowskim i Janem Szomburgiem) rozpoczynaliśmy działalność w Instytucie Badań nad Gospodarką Rynkową, pierwszym polskim think tanku, którego misją była transformacja ustrojowa i gospodarcza. Profesor Górski w tym samym czasie zakładał wraz z partnerami spółkę konsultingową PREMIUM-econ zajmującą się doradztwem w projektach prywatyzacyjnych i restrukturyzacyjnych. Ta zbieżność działań wynikała prawdopodobnie z przekonania, że wyzwania, z którymi musiała zmierzyć się Polska na początku lat dziewięćdziesiątych wymagają większego i bardziej praktycystycznego działania ze strony środowiska akademickiego.

Również w tym samym czasie pełniliśmy funkcje przewodniczących rad nadzorczych: Profesor M. Górski - Rady Nadzorczej Wielkopolskiego Banku Kredytowego, a ja - Rady Nadzorczej Banku Gdańskiego, a także kierowników Katedr Bankowości - On na Uniwersytecie Warszawskim, ja na Uniwersytecie Gdańskim.

Pozwoliło to nam bliżej się poznać na różnego rodzaju spotkaniach i seminariach związanych z pełnieniem tych funkcji. Profesor Marian Górski zawsze imponował mi swoim systemowym, makroekonomicznym podejściem do stabilności systemu finansowego. Odróżniał się od innych naszych kolegów wnikliwością badawczą i rozwagą.

Podziwiałem Go również jako promotora prac doktorskich. W 2009 roku miałem zaszczyt być recenzentem jednej z nich: pracy doktorskiej 
Moniki Kałuży-Wiśniewskiej dot. centralnych międzybankowych systemów płatności. Była to jedna z najlepszych prac, które zdarzyło mi się recenzować.

Jednego tylko żal. Szkoda, że i On, i ja jesteśmy już tacy starzy, że spotykamy się już tylko na jubileuszach. 


\section{STANISEAW PIAZTEK}

\section{Kilka uwag na siedemdziesięciolecie}

Profesora Mariana Górskiego znam od momentu, gdy dołączyłem do grona pracowników ówczesnego Instytutu Zarządzania Uniwersytetu Warszawskiego. Równolegle i niemal równocześnie toczyły się nasze losy zawodowe. W tym samym czasie pisaliśmy doktoraty i robiliśmy habilitacje. Wydaje mi się, że bardzo podobnie korzystaliśmy w tych latach z możliwości rozwoju, kształcenia i gromadzenia doświadczeń, jakie stwarzało środowisko naukowe Wydziału Zarządzania UW. Nowe perspektywy i możliwości otworzyły się przed Wydziałem Zarządzania wraz ze zmianami ustrojowymi na przełomie lat osiemdziesiątych i dziewięćdziesiątych. W roku 1990 Profesor Górski zaproponował mi, jako Dziekan, uczestnictwo w swoim zespole, który miał wykorzystać otwierające się szanse i możliwości. Byłem Mu za to bardzo wdzięczny i miło wspominam okres tej współpracy. Odpowiadałem w kolegium dziekańskim za sprawy badań naukowych, które choć niewątpliwie ważne, ustępowały znaczeniem takim sprawom, jak gwałtownie rosnąca liczba studentów, nowe programy oraz uczestnictwo pracowników naukowych w tworzeniu wolnorynkowych ram funkcjonowania gospodarki. Mogłem obserwować z jaką energią Profesor Górski przystąpił do modernizacji studiów i budowania nowych form kształcenia odpowiadających ogromnemu zainteresowaniu sprawami zarządzania. Dla Wydziału Zarządzania rozpoczął się trwający dwie dekady okres prosperity, któremu niewątpliwie sprzyjały okoliczności, napływ inwestycji, sytuacja na rynku pracy, nowe metody zarządzania. Ich wykorzystanie wymagało jednak różnych nowatorskich przedsięwzięć zainicjowanych przez Profesora Górskiego, które przynosiły owoce dla Wydziału przez następne lata. Wiele utrwalonych, sprawdzonych sposobów postępowania, wymagan i procedur kształtujących charakter i pozycję Wydziału Zarządzania ma swój początek w tym czasie.

Wydział promieniował również na zewnątrz. W tym okresie pracownicy Wydziału Zarządzania odcisnęli swój wyraźny ślad na przekształceniach 
ustrojowych i własnościowych polskiej gospodarki w takich sprawach, jak budowanie systemu ochrony konkurencji, instytucji finansowych, ładu korporacyjnego i prywatyzacji. Profesor Górski miał pełne zrozumienie dla tych aspiracji środowiska naukowego i potrzeby organizowania współpracy z otoczeniem Wydziału. Temu celowi służyła inicjatywa powołania w roku 1991 Fundacji na rzecz Wydziału Zarządzania Uniwersytetu Warszawskiego, w której obydwaj jesteśmy fundatorami. Fundacja działająca do dnia dzisiejszego znakomicie przyczyniła się do upowszechniania wiedzy i umiejętności z zakresu zarządzania oraz włączania pracowników nauki do praktyki gospodarczej. Dzięki Fundacji udało się zrealizować wiele przedsięwzięć wzbogacających ofertę Wydziału. Dorobek dziekański dwóch kadencji Profesora Górskiego to silne środowisko naukowe o uznanej pozycji wśród instytucji nowej gospodarki rynkowej i jeden z największych wydziałów Uniwersytetu. Jednocześnie miejsce przyjazne, otwarte na nowe idee, zapewniające wolność i swobodę działania twórczego.

Moje uznanie dla wiedzy i doświadczenia Profesora Górskiego ma również źródło w obserwacji Jego osiągnięć w praktyce gospodarczej. Jako prawnik funkcjonujący $\mathrm{w}$ środowisku osób zajmujących się zarządzaniem, inwestycjami i finansami zawsze starałem się korzystać z wiedzy i doświadczenia kolegów. Profesor Górski odniósł w tej dziedzinie wiele sukcesów, pełniąc odpowiedzialne funkcje w ciałach nadzorczych wiodących instytucji sektora finansowego, uczestnicząc $\mathrm{w}$ procesach restrukturyzacji i przekształceń własnościowych. Jako osoba rozumiejąca teorię finansów, ale również jako bezpośredni uczestnik procesów zarządzania w różnych instytucjach finansowych i gospodarczych jest $\mathrm{w}$ tych sprawach znakomitym rozmówca i przewodnikiem. Diagnozy i prognozy Profesora Górskiego sprawdzają się i pozwalają na zrozumienie dynamiki i zmienności procesów gospodarczych zachodzących w polskiej gospodarce.

Profesor Górski jest człowiekiem Uniwersytetu, który całą swą wiedzę i umiejętności postawił do dyspozycji uczelni. Jako wieloletni przedstawiciel Wydziału w Senacie Uniwersytetu tłumaczył nam zawiłości polityki uczelnianej. Wielkie są Jego zasługi dla prowadzenia gospodarki finansowej instytucji uczelnianych zarówno na szczeblu uniwersyteckim, jak i wydziałowym. W trudnych sprawach na posiedzeniach Rady Wydziału jest nieocenionym źródłem spokoju i wyważonych propozycji. Przedstawia sprawy zwięźle, więc i mój tekst taki być powinien.

Życzę Panu Profesorowi Górskiemu wielu dalszych sukcesów, a przede wszystkim zdrowia i wielu radości. Dzisiejsza siedemdziesiątka, to dawna pięćdziesiątka, więc jest jeszcze wiele rzeczy do zrobienia. 


\section{EWA PIETRUSIŃSKA, ROBERT PIETRUSIŃSKI}

\section{Profesor Marian Górski}

Jest osobą, którą, jak nam się wydaje, dobrze znamy i jeśmy z Nim zżyci. Mieliśmy wiele wspólnych projektów i innych ciekawych wspomnień.

W 1992 roku razem z Marianem Górskim, Anną Bielecką, Stanisławem Piątkiem i Janem Buczowskim założyliśmy Fundację Na Rzecz Wydziału Zarządzania Uniwersytetu Warszawskiego. Fundację miało założyć wiele osób... Do notariusza dotarła tylko nasza piątka. No cóż, był to okres strajków komunikacyjnych.

Fundacja wspiera i realizuje zadania naszego Wydziału. W szczególności prowadzi działalność szkoleniową. Zarząd Fundacji składa się z 3 osób: Mariana Górskiego, Piotra Sokoła i Roberta Pietrusińskiego. Rola Mariana w zarządzie jest nieodzowna. Jest On trzonem naszego zespołu.

W połowie lat dziewięćdziesiątych, razem z Marianem, pomagaliśmy w prywatyzacji przedsiębiorstwa branży odzieżowej „Cora Garwolin” w Garwolinie. Spółka powstała w drodze prywatyzacji bezpó́redniej, czyli pracownicy założyli spółkę z inwestorem strategicznym. Spółka otrzymała do odpłatnego korzystania mienie przedsiębiorstwa państwowego, a następnie stała się jego właścicielem. Po prywatyzacji znaleźliśmy się w radzie nadzorczej spółki akcyjnej Cora Garwolin. Byliśmy w tej radzie przez trzy lata. Posiedzenia rady nadzorczej odbywały się raz w miesiącu. Jeździliśmy z Marianem jednym samochodem. W czasie jazdy poruszaliśmy różne problemy, żartowaliśmy i robiliśmy zakupy. Marian, pochodzący z Augustowa, jest specjalistą w materii kupowania i przyrządzania grzybów. Wzorowałem się na jego poczynaniach w zakresie zakupów i porad kulinarnych. Interesujące jest to, iz byliśmy powołani do rady nadzorczej przez akcjonariuszy pracowników, a przewodniczący związku zawodowego przez inwestora. W spółkach, które podlegają komercjalizacj/prywatyzacji pracownicy mają prawo wyboru części składu rady nadzorczej. Przepisy nie określają czy ma to być pracownik, czy 
osoba, która jest spoza spółki. Z zasady wybierają oni pracowników swojej spółki. W naszym przypadku uznano, że jako pracownicy Uniwersytetu Warszawskiego spoza spółki będziemy lepiej sprawować czynności nadzorcze. Na marginesie warto zauważyć, iż w przepisach ustawy o prywatyzacji przedsiębiorstw państwowych pracownicy w radach nadzorczych nie musieli mieć żadnych kwalifikacji. Dopiero potem wprowadzono przepisy, że członkowie rad nadzorczych muszą mieć zdany państwowy egzamin kandydatów na członków rad nadzorczych (istniały ustawowe zwolnienia z egzaminu, np. doktorat $\mathrm{z}$ prawa lub ekonomii). Zasadę tę powtórzyły przepisy ustawy z dnia 16 grudnia 2016 r. o zasadach zarządzania mieniem państwowym. Jednak już 1 marca 2018 r. nastąpiła nowelizacja tej ustawy. Według niej „osoby wybrane przez pracowników nie muszą mieć kwalifikacji określonych w ustawie z 16 grudnia 2016 r.”. Tym bardziej istotne było dla nas, że zostaliśmy wybrani przez akcjonariuszy pracowników do rady nadzorczej.

Byliśmy z Marianem członkami państwowej komisji egzaminacyjnej kandydatów na członków rad nadzorczych spółek z udziałem Skarbu Państwa. W tamtych czasach były to egzaminy wyjazdowe do miejsca szkolenia. Później egzaminy odbywały się w MSP. Kiedyś, w czasie wakacji, poproszono nas o udział w przeprowadzeniu egzaminu. Zazwyczaj członkami komisji egzaminacyjnej byli pracownicy Ministerstwa Skarbu Państwa. Nasz udział w komisji był wyjątkiem od tej zasady. Zaproszono nas do udziału w komisji egzaminacyjnej, ponieważ zdawali egzamin członkowie partii politycznej (już nie istniejącej) $\mathrm{i}$ chciano, aby egzamin przeprowadzały osoby niebędące pracownikami MSP (Minister reprezentował inną partię niż zdający). Egzamin pisemny zaliczyły dwie osoby i na szczęście dały sobie one również radę na egzaminie ustnym.

Inwestorem w Corze Garwolin S.A. był Jarosław Ptaszek. Mieliśmy okazję poznać tego wspaniałego człowieka i przedsiębiorcę, jednego z większych na świecie producentów kwiatów, którego orchidee nie mają sobie równych. Wielokrotnie nas gościł. Przy okazji poznaliśmy całą rodzinę Jarosława. Przedsiębiorstwo, które prowadzą JMP Flowers jest dobrym przykładem rozwoju polskiego przedsiębiorcy.

Mamy okazję wspominać z Marianem dawne czasy oraz rozmawiać na temat aktualnych wydarzeń na corocznych konferencjach wyjazdowych Naszego Wydziału. Rozmowy zaczynają się już w autokarze, gdzie dołącza się Ewa Pietrusińska. Dyskusja zaczyna przybierać na sile... 


\section{RYSZARD RAPACKI}

\section{Tekst „wspomnieniowy” do ksiązi jubileuszowej Profesora Mariana Górskiego}

Mariana Górskiego (a dla rodziny i przyjaciół - po prostu Marka) znam już 40 lat. Poznaliśmy się we wrześniu 1978 roku. Po wprowadzeniu się do tzw. mieszkań rotacyjnych w bloku przy ul. Bernardyńskiej nad jeziorkiem Czerniakowskim okazało się, że naszymi najbliższymi sąsiadami w mieszkaniu naprzeciwko jest rodzina Państwa Górskich. Sąsiedztwo okazało się bardzo sympatyczne i wkrótce przerodziło się w bliższą znajomość czy wręcz zażyłość. Nasze rodziny zbliżyły do siebie nie tylko podobne doświadczenia zawodowe „głównych żywicieli”, profil wykształcenia naszych żon (obie są ekonomistkami) i wiek naszej progenitury (synowie Marka i Grażyny są niemal w tym samym wieku co nasze córki), lecz także (a może przede wszystkim) wspólnie przeżywane mroki stanu wojennego i podobnie doświadczane klęski żywiołowe (w rodzaju „zimy stulecia” w 1979 roku, kiedy awaria centralnego ogrzewania doprowadziła temperaturę $\mathrm{w}$ mieszkaniach do poziomu 7 stopni i nasze dzieci sypiały przez ten czas razem, dogrzewając się ciepłem własnych ciał).

Po naszej wyprowadzce z Bernardyńskiej w 1985 r. moje relacje z Markiem $\mathrm{i}$ jego rodziną nieco się $-\mathrm{z}$ oczywistych względów - rozluźniły, ale nadal utrzymywaliśmy i do dziś utrzymujemy stałe kontakty na niwie zarówno prywatnej, jak i zawodowej. Z Markiem i Grażyną spotykamy się towarzysko kilka razy do roku, a znacznie częściej dzwonimy do siebie, dzieląc się naszymi przeżyciami, doświadczeniami i refleksjami. Bardzo miło wspominam w tym kontekście odwiedziny Marka w East Lansing w 1992 r. Byłem w tym czasie z rodziną na stypendium Fullbrighta w Michigan State University. Marek, w trakcie któregoś ze swoich wyjazdów szkoleniowych do USA, postanowił nieco zboczyć ze swojej trasy i wpadł do nas na kilka dni, aby podzielić się wieściami z kraju. 
W czasie 40-letniej znajomości mieliśmy także okazję zadzierzgnąć z Markiem nieco bliższe kontakty zawodowe i współpracować przy wspólnych projektach naukowych. W dwóch z nich rolę katalizatora odegrał nasz wspólny, nieżyjący już niestety, przyjaciel z Wielkiej Brytanii - mający polskie korzenie - profesor George Blazyca z Glasgow. Dwukrotnie miałem zaszczyt i przyjemność współredagować z nim wydane w Wielkiej Brytanii wieloautorskie książki (Poland into the 1990s, Pinter 1991 i Poland into the New Millennium, Edward Elgar 2001), w których do napisania dwóch rozdziałów zaprosiliśmy m.in. Marka.

Po śmierci George’a jego współpracownicy na uniwersytecie Paisley w Glasgow zorganizowali w 2006 roku międzynarodową konferencję poświęconą jego pamięci. Zostaliśmy tam zaproszeni wraz z Markiem. Efektem konferencji była książka pod redakcją profesorów Martina Myanta i Terry Coxa (Reinventing Poland. Economic and political transformation and evolving national identity, Routledge 2008), w której znalazły się m.in. napisane przez Marka i przeze mnie rozdziały oparte na naszych wystąieniach na konferencji. 


\section{KAZIMIERZ RYĆ}

\section{Profesor Marian Górski}

Profesora Mariana Górskiego, którego znam od blisko pół wieku, podziwiam za to, że zawsze daje sobie radę..., no może prawie zawsze. Absolwent Wydziału Ekonomii Uniwersytetu Warszawskiego, kierunku Ekonometrii, po odbytym rocznym stażu na macierzystym Wydziale, okazał się bardzo potrzebny na stanowisko asystenta w Zakładzie Konsumpcji i Rynku, w nowo utworzonym, w 1972 roku, samodzielnym Instytucie Zarządzania UW. Również dzięki niemu skompletowanie kadry do prowadzenia zajęć dydaktycznych - za co w tym Instytucie odpowiadałem - okazało się łatwiejsze, niż myślałem. Magister Górski, jak i Jego trzy koleżanki z roku, które przyszły wraz z Nim, wiele potrafili. Uczyli zarówno ekonomii, planowania, statystyki, jak i matematyki.

Marian wyróżniał się nie tylko w dydaktyce. Jeszcze jako młody magister stał się współautorem naukowej publikacji książkowej wydanej przez PAN, pod nieco ponuro brzmiącym tytułem: Denaturalizacja spożycia żyrwności w wiejskich gospodarstwach domowych. Autorzy książki: Roman Głowacki, Marian Górski, Kazimierz Ryć. Rok wydania: 1976. Recenzent: dr hab. Czesław Kos.

Tytuł książki był zgodny ze zleconym przez Instytut Rozwoju Wsi i Rolnictwa PAN Instytutowi Zarządzania UW tematem badawczym. Magister Marian Górski zorganizował badania terenowe w kilku gminach, wykorzystując studentów piszących prace magisterskie w ramach seminariów moich i prof. R. Głowackiego. Przy opracowaniu materiałów zebranych przez studenckich ankieterów błysnął swoimi umiejętnościami, godnymi przodującego absolwenta ekonometrii na UW.

Marian radził sobie znakomicie nie tylko w sprawach zawodowych, lecz także życiowych. Świadectwem może być Jego przygoda w podróży. Wybraliśmy się wspólnie, również z profesorem Głowackim, do Pragi na 
zaproszenie Uniwersytetu Karola. Kłopoty zaczęły się już w chwili rezerwacji biletów. Nieopacznie poprosiłem sekretarkę o rezerwację na „Batory”, nie wyjaśniając, że chodzi o nazwę pociągu, nie zaś i nieistniejący już transatlantyk. Po nieudanej rezerwacji w Gdyni udało się w końcu kupić bilety w Warszawie, na miejsca sypialne w o tej właśnie nazwie pociągu zmierzającym do Budapesztu, a my zaś z przesiadką do Pragi. Niestety konduktor pociągu obudził tylko prof. Głowackiego i mnie, zapomniał o Marianie..., ale On sobie poradził(!). W końcu wszyscy trzej wylądowaliśmy jednak na statku, chociaż nie na oceanie, lecz na rzece Wełtawie, zacumowanym w Pradze, na którym urządzono przyjemny hotel i w którym gościnni gospodarze zarezerwowali nam pokoje.

Po uzyskaniu stopnia doktora Marian został - oprócz innych przedmiotów - wykładowcą ekonomii politycznej kapitalizmu. Nie był to jednak kapitalizm wg Karola Marksa, lecz wg Jana Pena, holenderskiego ekonomisty, zwolennika J.M. Keynesa. Jego podręcznik Wspótczesna ekonomia był dostępny po polsku. Nasi studenci, przyszli menedżerowie, więcej mogli się od wykładowcy dowiedzieć o mnożniku inwestycyjnym, niż o wartości dodatkowej w kapitalizmie.

Prof. Górski nadążał za zmianami - nazwijmy to - technologicznymi w badaniach naukowych i dydaktyce. To On właśnie pomagał również innym „oswoić' komputery w badaniach naukowych w Zakładzie Badania Cen w Komisji Cen i w Instytucie Finansów Ministerstwa Finansów, w których to instytucjach ze mną współpracował. Wprowadził też warsztaty komputerowe w nauczaniu makroekonomii na Wydziale Zarządzania. Jeszcze w latach osiemdziesiątych ówczesny przedstawiciel Banku Światowego w Polsce i późniejszy prezes Banku Centralnego niepodległej Estonii ze zdumieniem zapoznał się z naszymi badaniami równowagi makroekonomicznej i gratulował nam osiągnięć poznawczych.

Prof. Górski jest ceniony i lubiany, zarówno na Wydziale, jak i na Uczelni. Przez dwie kadencje prawie jednogłośnie był wybierany na Dziekana. W czasie pełnienia funkcji Dziekana zorganizował i rozwinął studia komercyjne, co wydatnie umocniło kondycję finansową Wydziału. W środowisku uczelni uznawany jest zasłużenie za dobrego finansistę i przez kilka ostatnich kadencji władz Uniwersytetu współzarządza naszymi finansami, z pozycji Przewodniczącego Komisji Finansowej UW. Na Uniwersytecie Warszawskim ceniony jest od dawna. Jeszcze jako młody doktor, zanim wyróżniono go medalami uczelni i odznaczeniami państwowymi, został wyróżniony przydziałem talonu na zakup samochodu marki Fiat 126p - z puli talonów uczelni - i mógł kłuć w oczy uczonych rówieśników na Wydziale czerwonym 
maluchem, jeszcze długo dla nich niedostępnym. Być może nawet silniej, niż dziś kłuje wypasionym Subaru swoich sąsiadów z miejscowości, w której obecnie rezyduje.

Zainteresowania naukowe Mariana w zakresie makroekonomii koncentrowały się na problemach polityki monetarnej i fiskalnej oraz na systemie bankowym. W tym też obszarze prowadził badania, pisał, publikował i podejmował działalność praktyczną. Mimo że swojej praktyki bankowej nie zwieńczył awansem na fotel premiera czy choćby ministra, co wskazuje, że jednak Marian nie wszystko potrafi(!), jako Jego dawny szef, a od dziesięcioleci kolega i przyjaciel, jestem dumny z Jego osiągnięć i życzę $\mathrm{Mu}$ dalszych sukcesów w nauce i powodzenia w życiu. Choć w kontaktach międzyludzkich Marian stał się z wiekiem mniej wylewny, pozostał jednak ciepły i życzliwy. Cieszę się, że możemy nadal, jak dotychczas, siedzieć ramię w ramię w pierwszej ławie na posiedzeniach Rady Wydziału, prowadzić ciekawe dyskusje i wspierać się wzajemnie. 


\section{PIOTR SOKÓE I JACEK KIRYŁO}

\section{O Profesorze Marianie Górskim}

Profesora Mariana Górskiego pamiętamy zarówno z czasów studenckich, a obaj studiowaliśmy na Wydziale Zarządzania, jaki i z pierwszych lat naszej aktywności zawodowej. Jednak najwięcej naszych wspomnień, i to zdecydowanie pozytywnych, pochodzi z okresu lat dziewięćdziesiątych, kiedy to Profesor Marian Górski przez dwie kadencje pełnił urząd Dziekana Wydziału, a nas zaangażował do realizacji nowatorskich wtedy przedsięwzięć.

Na początku lat dziewięćdziesiątych, a konkretnie w 1991 roku, Prof. Marian Górski zaproponował nam zorganizowanie i późniejsze poprowadzenie trzyletnich studiów licencjackich, początkowo tylko wieczorowych, a później również i zaocznych, w formule Dyplomowych Studiów Menedżerskich. Następnie zostały one uzupełnione o dwuletnie niestacjonarne Magisterskie Studia Menedżerskie, później zaś także pięcioletnie Magisterskie Studia Wieczorowe. Jednym z powodów uruchomienia studiów niestacjonarnych była możliwość i konieczność zagospodarowania zwalnianych obiektów w ramach dzisiejszej siedziby Wydziału przy Szturmowej 1/3. W tamtym czasie ze zgrupowania Szturmowa wyprowadził się Wydział Pedagogiczny Uniwersytetu Warszawskiego. Zwolnione pomieszczenia znajdujące się na piętrach od trzeciego do piątego w budynku Szturmowa 3 (obecnie budynek C) zostały przez Uniwersytet wynajęte szkole niepublicznej prowadzonej przez Fundację Primus. Piętro II i częściowo I chciała wynająć od Uniwersytetu jedna z prywatnych szkół wyższych. Profesor Marian Górski, będący wówczas Dziekanem Wydziału Zarządzania, zareagował natychmiast i uruchomił procedury związane z powołaniem studiów płatnych na poziomie licencjackim i zlokalizowaniem ich na zwolnionych przez Pedagogikę piętrach. Działania Profesora zablokowały konkurencję, a jednocześnie pozwoliły Wydziałowi Zarządzania na rozwinięcie i poszerzenie oferty edukacyjnej oraz zdecydowane zwiększenie przychodów. Dlatego bez wątpienia można 
Profesora Górskiego nazwać zarówno Ojcem studiów niestacjonarnych, jak i Konstruktorem mechanizmów pozyskiwania przez Wydział pozabudżetowych środków finansowych, co w przyszłości znakomicie przyczyniło się do rozwoju Wydziału.

Powierzając nam zorganizowanie od podstaw i późniejsze prowadzenie DSM, Prof. M. Górski dał nam jednocześnie daleko idącą samodzielność. Ważne decyzje, w tym przede wszystkim finansowe, programowe czy personalne wymagały oczywiście zgody Dziekana, a w praktyce były przygotowywane przez tak zwaną Radę Programową DSM, w skład której wchodzili członkowie kolegium dziekańskiego i dodatkowo powołani przez Dziekana przedstawiciele poszczególnych Katedr. Rada Programowa działała trochę na podobieństwo rady nadzorczej, na posiedzenia której byliśmy przez Prof. M. Górskiego każdorazowo zapraszani w celu składania sprawozdán, przedstawiania najważniejszych problemów związanych z funkcjonowaniem DSM i propozycji ich rozwiązania. Posiedzenia Rady Programowej, jakkolwiek czasochłonne i wymagające precyzyjnego przygotowania, zawsze dzięki stanowczości Przewodniczącego kończyły się podjęciem konkretnych i konstruktywnych rozstrzygnięć. Konkretnie, ale za to wątpliwie konstruktywnie $\mathrm{w}$ trakcie jednego z posiedzeń Rady zachowali się natomiast miłośnicy dobrych samochodów i jednocześnie amatorzy cudzej własności. Ze współczuciem spoglądaliśmy na Profesora, który z niedowierzaniem rozglądał się po wydziałowym parkingu $\mathrm{w}$ poszukiwaniu zaparkowanego kilka godzin wcześniej auta.

Początki DSM były, jak zresztą każdej organizacji, trudne. Brakowało wielu rzeczy, a wiele spraw było zupełnie nowych. Tu zawsze można było liczyć na pomoc Prof. M. Górskiego, który często uruchamiał swoje kontakty. Dzwoniąc do absolwentów Wydziału, Profesor na początku rozmowy zawsze zadawał pytanie: - Czy ja Pani/Pana nie skrzywdzitem? Dzięki takim kontaktom wyposażone zostały pomieszczenia biurowe DSM. Prof. M. Górski skierował nas m.in. do polsko-brytyjskiej fundacji działającej w obszarze ochrony zdrowia. Otrzymaliśmy od niej meble, a wśród nich welurową kanapę, na której, jak nas poinformowano, siedziała księżniczka Anna, podczas jej pobytu w fundacji. Dzięki Prof. M. Górskiemu DSM uzyskał meble z tzw. arystokratyczną duszą. Pozostałości tego umeblowania do dzisiaj znajdują się w różnych pomieszczeniach Wydziału.

Pochodzące z czesnego, z utworzonych przez prof. M. Górskiego studiów niestacjonarnych, przychody umożliwiły Wydziałowi uruchomienie polityki remontowej, a w późniejszych latach także inwestycyjnej. To właśnie Profesor M. Górski na szeroką skalę rozpoczął remonty budynków 
Wydziału Zarządzania. Zyskał nawet miano Ojca Łazienek Wydziałowych, bo dzięki Niemu powstały w tamtym czasie sanitariaty nie gorsze niż w Pałacu Kazimierzowskim.

W okresie wakacyjnym, kiedy odświeżane były sale wykładowe, dziekanaty i pokoje wykładowców, widać było wyraźne zaniepokojenie Profesora. Rok akademicki tuż, tuż..., a uniwersyteckie ekipy remontowe mają znaczne opóźnienie. $Z$ tamtego okresu przypominam sobie następującą sytuację. Wraz z Profesorem sprawdzaliśmy postęp prac. W jednym z pomieszczeń zastaliśmy malarza, który niemrawo malował kaloryfer. Na pytanie Profesora, kiedy zakończy prace, malarz milczy. Informujemy, że pytanie zadał Dziekan Wydziału, a więc kierownik. W odpowiedzi malarz stwierdza filozoficzne - każdy ma swoich kierowników, on także. Profesor Górski zachował stoicki spokój. Uznał, że ważniejsze od awantury jest terminowe skończenie remontów. I rzeczywiście zawsze tak się kończyło.

Dziękując Szanownemu Jubilatowi za lata owocnej i konstruktywnej współpracy, nieocenialne pokłady nabytej wiedzy i wszechstronnych wykorzystywanych przez lata doświadczeń, życzliwość i zawsze odczuwalne wsparcie, Zyczymy jednocześnie dalszej jak najdłuższej i realizowanej w jak najlepszej kondycji aktywności na rzecz Wydziału i Uniwersytetu. 


\section{MARIUSZ TROJANOWSKI}

\section{Profesor Marian Górski w moich oczach...}

Z Profesorem Marianem Górskim zetknąłem się jako student drugiego roku Wydziału Zarządzania w semestrze zimowym roku akademickiego 1989/90. Uczestniczyłem w wykładzie prowadzonym przez Pana Profesora pt. „Ekonomia polityczna”. Wcześniej, jako student pierwszego roku, zbierałem bardzo dobre oceny. Gdy zaś przystąpiłem do egzaminu prowadzonego przez Profesora Górskiego, zdałem go (jak sądzę) bardzo słabo, otrzymując ledwie ocenę dostateczną. To była lekcja pokory. Drugi egzamin zdawany u Profesora Górskiego, już na piątym roku, z przedmiotu „Pieniądz i kredyt”, wywołał u mnie dużą mobilizację. Pomny wcześniejszych doświadczeń, tym razem przygotowałem się o wiele lepiej i otrzymałem ocenę bardzo dobrą. Cieszyłem się niesłychanie, gdyż to był przecież egzamin „u samego Pana Profesora Mariana Górskiego!”. Profesor okazał się nauczycielem wymagającym, ale sprawiedliwym i za tę lekcję jestem $\mathrm{Mu}$ bardzo wdzięczny.

Po ukończeniu studiów zacząłem pracować na Wydziale Zarządzania UW jako doktorant w Katedrze Marketingu. Po dwóch latach wystąpiłem z prośbą o zatrudnienie mnie na Uczelni na stanowisku asystenta. Dziekanem Wydziału był w tym czasie Profesor Marian Górski. Polityka Uniwersytetu Warszawskiego zakładała wówczas wstrzymanie zatrudniania asystentów. Dziekan - Profesor Górski - podjął jednak decyzję pozytywną dla mnie i dzięki niej zostałem asystentem na Wydziale Zarządzania UW. Nie śmiem oceniać mojej przydatności dla Wydziału Zarządzania, ale wiem, że Pan Dziekan wykazał się menedżerskim zdecydowaniem, dla mnie skutkującym wielką satysfakcją z pracy na tym Wydziale.

Z nielicznych (nad czym boleję) prywatnych rozmów z Profesorem M. Górskim wnoszę, że jest osobą bardzo doświadczoną, pragmatyczną oraz 
mającą bardzo dobry kontakt z praktyką. Prywatnie niezwykle cenię Profesora Górskiego za znakomite poczucie humoru :)

W moich oczach Profesor Górski jest bardzo znaczącą postacią Wydziału Zarządzania Uniwersytetu Warszawskiego. Profesor budzi moją wdzięczność, szacunek i sympatię. Cieszę się, że w mojej edukacji i pracy zawodowej mogłem spotkać Profesora Górskiego (:) 


\section{RADOSEAW WINIARSKI}

\section{Profesor Górski w moich oczach...}

\section{Mentor}

Podczas niedawnego spotkania z prezesem zarządu jednego z domów maklerskich, który okazał się być absolwentem Wydziału Zarządzania Uniwersytetu Warszawskiego, zostałem zapytany o Kierownika Katedry na WZ, której jestem pracownikiem. Usłyszawszy nazwisko Profesora Mariana Górskiego rozmówca uśmiechnął się z szacunkiem i ze zrozumieniem. Była to reakcja wśród teoretyków i praktyków rynku finansowego, z jaką spotykałem się dotychczas bez wyjątku w sytuacji rozmowy czy wspomnień o Profesorze. Dlaczego spotkanie na swojej drodze Profesora Górskiego było dla mnie ważne? Dzięki Profesorowi zrozumiałem, iż umiejętność „czytania rynków finansowych" bez solidnych podstaw makroekonomii sprowadza się jedynie do czystej intuicji. Pisząc o wspomnieniach dotyczących Prof. zw. dr hab. Mariana Górskiego niezręcznie jest mi odnosić się do moich własnych doświadczeń, ponieważ dzięki niekwestionowanej umiejętności zjednywania sobie sympatii i budowania przez Profesora zespołów, naturalnym oraz mam nadzieję bardziej uprawnionym jest odniesienie się do doświadczeń Naszych, czyli pracowników dzisiaj Katedry Systemów Finansowych Gospodarki Wydziału Zarządzania Uniwersytetu Warszawskiego. Dla nas Szef Katedry był i jest Profesorem lub po prostu Profem. Obecność Profesora gwarantowała zawsze ciekawą dynamikę dyskusji. Dzięki temu narastało w nas przekonanie, iż aby mieć coś ciekawego do przekazania, niezbędne jest gruntowne przygotowanie oraz wnikliwa analiza debaty. Świetny warsztat, unikalna umiejętność syntezy oraz koncentracja na rzeczach istotnych dawała Profesorowi przewagę nad uczestnikami dyskusji, którym w odróżnieniu od Profesora, zdarzało się powtórzyć. 


\section{...gdzie dwóch ekonomistów tam trzy opinie}

O fakcie, iż ekonomia jest nauką społeczną mieliśmy okazję przekonać się niejednokrotnie podczas rozmów prowadzonych w Katedrze, przy okazji seminariów, spotkań w ramach zakładu czy koleżeńskich debat. Wydaje się, iż Profesor nigdy nie kwestionował aktualności powszechnie powtarzanego powiedzenia: „gdzie dwóch ekonomistów tam trzy opinie”. Umiejętność inicjacji i prowadzenia, przez Profesora swobodnej dyskusji tworzyła klimat, w którym każdy czuje się zaproszony do wyrażenia własnej opinii. Uczestnicy tych rozmów mogli niejednokrotnie odnieść wrażenie, iż co prawda ekonomia jest nauką społeczną o gospodarowaniu w warunkach ograniczonych zasobów, to jednak ułomność natury ludzkiej komplikuje zarówno definicję pojęcia gospodarowania, jak i rzadkości zasobów.

\section{Finansista bez portfela}

Niekiedy dyskusje o Wydziale Zarządzania, metodach kształcenia, studentach i nas samych przenosiły się do urokliwego miejsca, w którym Profesor wypoczywał. Szef Katedry stawał się gospodarzem i... ogrodnikiem. Mając świadomość, iż podczas wspólnych spotkań nie rozstrzygniemy wciąż aktualnych z upływem czasu pytań czy uczelnia o takim profilu powinna kształcić rzemieślników, czy teoretyków, chętnie korzystaliśmy z nieczęstych okazji spotykania się poza murami Wydziału Zarządzania, mając świadomość przynależności do zespołu, który z pewnością również dzięki temu stawał się dla nas coraz bardziej wyrazisty. Podczas jednego ze spotkań Profesor spostrzegł na jednym z krzeseł opuszczonego właśnie stołu biesiadnego portfel. Zanim gospodarz skierował na nas pytające spojrzenie moja pusta kieszeń nie pozostawiała mi złudzeń iż należał on do mnie. Jak zawsze w tego typu sytuacjach Profesor spuentował całą sytuację pytaniem, nie oczekując odpowiedzi: „... a który to finansista bez portfela chodzi?”.

\section{Najważniejszy jest zespół}

Zgodnie z powiedzeniem Jacka Canfielda „człowiek ma w życiu albo wymówki albo wyniki” Profesora Górskiego zawsze określały wyniki. Jeszcze jako student WZ UW zostałem uświadomiony, iż świetna znajomość makroekonomii i zamiłowanie do modelowania $\mathrm{w}$ obszarze rynków finansowych 
i gospodarki, ustępującego wtedy, Dziekana Wydziału Zarządzania była konsekwencją wyboru studiów na Wydziale Nauk Ekonomicznych UW. Współpraca w obszarze naukowo-dydaktycznym z Profesorem Górskim już w Zakładzie Bankowości i Rynków Pieniężnych to okres poznawania Profesora jako praktyka rynku finansowego i korzystania z jego bogatego praktycznego doświadczenia jako: wieloletniego członka organów spółek kapitałowych, konsultanta, lidera, aktywnego uczestnika zmieniającej się dynamicznie w procesach restrukturyzacji i prywatyzacji gospodarki. Możliwość dostępu do praktycznej wiedzy dla świeżo upieczonych wtedy asystentów była dla nas bezcennym doświadczeniem. Poczucie odpowiedzialności lidera za zespół uwidaczniało się w poczynaniach Profesora wielokrotnie. Podczas publicznej obrony mojej dysertacji doktorskiej, zaaferowany operacją w szpitalu kilkuletniej córki, niemalże zaskoczyłem siebie i wszystkich uczestników wydarzenia, w tym komisję egzaminacyjną, brakiem autoreferatu, który w kilkudziesięciu egzemplarzach został w domu. W tej trudnej sytuacji mogłem jednak liczyć, jak zawsze, na pomoc serdecznych koleżanek i kolegów z Katedry. Ich szybka reakcja, mobilizacja i pomysłowość zapewniły mi tego popołudnia komfort obrony mojej pracy, natomiast Profesorowi poczucie satysfakcji mobilizującego się w trudnych sytuacjach zespołu. Zgrany zespół to warunek konieczny sprawnie funkcjonującej Katedry Systemów Finansowych Gospodarki i jej zakładów w przyszłości. Świadomość ta zawsze obecna była w działaniach Profesora dotyczących pracowników naukowo-dydaktycznych podległych mu jednostek organizacyjnych. Profesor zawsze uczył nas, aby w pierwszej kolejności wymagać od siebie. Do dzisiaj implementacja tej zasady wydaje mi się wciąż szalenie trudna, jednakże jej praktykowanie dostarcza mi wiele satysfakcji, za co Panie Profesorze bardzo dziękuję. Patrząc na efekty wieloletniej pracy naukowo-dydaktycznej oraz organizacyjnej, mam nadzieję, że Profesor ze spokojem i komfortem będzie planować dalszy rozwój Katedry, będąc jeszcze przez długie lata jej mentorem, liderem, szefem zespołu i „głównym ekonomistą". 


\section{ELEONORA ZIELIŃSKA}

\section{Profesor Marian Górski w moich oczach...}

\section{Jako człowiek rodzinny i niezwykle gościnny...}

Nasze losy z Marianem splotły się dzięki dzieciom: Marcinowi, starszemu synowi Profesora oraz mojej córce Monice. Patrząc z dystansu przeszło dwudziestu lat na naszą znajomość, widzę, że spotkaliśmy się na podobnym etapie życia, wyznaczonym budową rodzinnych domów. Zarówno Marian, jak i jego żona Grażynka chcieli, by ich dom integrował całą rodzinę przy niedzielnych obiadach, był miejscem licznych spotkań towarzyskich oraz wspólnych zabaw wszystkich wnuków, co w pełni im się udało. Pamiętam rozczarowanie Mariana, gdy przed weselem naszych dzieci, które zamierzał urządzić w swoim nowym domu, nie zrobiono na czas specjalnie zamówionego wielkiego stołu. Stół ten jednak w końcu stanął i stał się symbolem rodzinności i gościnności Gospodarzy, świadkiem wyrafinowanych doznań kulinarnych dla dorosłych: licznej rodziny i oddanych Marianowi „od zawsze” przyjaciół ze studiów oraz nowych sąsiadów. Jest też miejscem, gdzie na wnuków zawsze czeka alternatywne menu złożone z ulubionych przez każdego z nich potraw. Otaczający dom piękny ogród nie tylko pozwala na wytchnienie, lecz także stanowi wspaniały plac sportowy dla dzieci. Prawdziwie podziwiam Mariana i jego żonę Grażynkę, z której zdaniem zawsze się bardzo liczy, za to co wspólnie stworzyli. Trochę im także zazdroszczę, że mnie się to, w takim stopniu, nie udało.

\section{Jako esteta...}

Jak wiele osób, wrażliwa jestem na urodę, zwłaszcza męską. Marian to nie tylko bardzo przystojny mężczyzna, ale też elegant o wyrafinowanym 
stylu. Jego dobry gust widoczny jest zarówno w ubiorze, jak i w otaczaniu się pięknymi przedmiotami. Wyszukiwanie ładnych „staroci” na warszawskim Kole, to nasza wspólna pasja. Dzięki niej ich dom jest rodzinny i gościnny, ale także pięknie urządzony.

\section{Jako podróżnik...}

Marian jest ciekawy świata i otwarty na podróże. Przy kilku okazjach, kiedy to wyjeżdżaliśmy rodzinnie, przekonałam się, że potrafi znakomicie zaplanować trasę oraz program turystyczno-kulturalny, tak by pokazać w atrakcyjny sposób wszystkie uroki odwiedzanych miejsc. Innymi słowy, uczynić każdą podróż zarówno pouczającą, jak i przyjemną, dzięki czemu zapamiętuje się ją na całe życie.

\section{Jako naukowiec...}

Chociaż pracujemy na tym samym Uniwersytecie, wspólnych zainteresowań naukowych z Profesorem nie mamy. Niemniej jednak często wymieniamy się doświadczeniem dydaktycznym oraz dyskutujemy o sprawach środowiska akademickiego. Podziwiam nieustający entuzjazm Mariana dla dydaktyki, wysokie wymagania, jakie stawia studentom, ale przede wszystkim sobie. $\mathrm{Z}$ uwagą śledziłam też determinację w zdobywaniu najwyższych tytułów naukowych oraz entuzjazm, z jakim podejmował coraz to nowe wyzwania w imię dobra nauki i środowiska uniwersyteckiego (czy to kierując Wydziałem Zarządzania, czy też np. działając w Senacie UW).

\section{Jako osoba niedbająca o własne zdrowie...}

Szerokie pole aktywności zawodowej, rodzinnej i towarzyskiej sprawia, że Marian często niewystarczająco myśli o sobie, zwłaszcza o swojej kondycji zdrowotnej. Musi bardzo cierpieć, żeby dał się namówić na badania lub konsultację lekarską. Napawa to nas wszystkich niepokojem. W związku z tym, życzę Jemu oraz osobom nam najbliższym, żeby wykazał się dobrze rozumianym egoizmem i bardziej dbał o własne zdrowie. 
